\title{
POLICY INNOVATION IN DUTCH MUNICIPALITIES
}

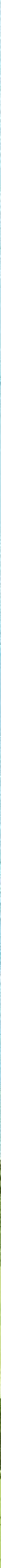


Policy innovation in Dutch municipalities 


\section{COLOFON}

The research undertaken in this project was facilitated by the Institute for Innovation and Governance Studies (IGS) and the Department of Public Administration (PA) of the University of Twente.

Cite as: Jans, W. (20 I 5) Policy innovation in Dutch municipalities. Dissertation. Enschede, The Netherlands: University of Twente.

Copyright (C) $20 \mathrm{I} 5$ by Wouter Jans. All rights reserved.

Cover design by Jedi Noordegraaf, Studio Vandaar - www.studiovandaar.nl

Cover design inspired by 'De Wachter' (Oostdijk, Willemstad) of Marius Boender

Typeset in I 0.5 point Fanwood and Junction - www.theleagueofmoveabletype.com

Printed by GVO drukkers \& vormgevers B.V. - www.gvo.nl on unbleached FSC-paper

ISBN: $978-90-365-3987-6$

DOI: $10.3990 /$ I. 9789036539876 


\section{POLICY INNOVATION \\ IN DUTCH \\ MUNICIPALITIES}

Wouter Jans

University of Twente

Institute for Innovation and Governance Studies (IGS)

Enschede, The Netherlands 


\section{DOCTORAL COMMITTEE}

Promotors

Prof. dr. A. Need

Prof. dr. S. A. H. Denters

Co-promotor

Dr. M. van Gerven

Graduation Committee

Prof. dr. J. A. G. M. van Dijk (University of Twente)

Prof. dr. A. J. Meijer (Utrecht University)

Prof. dr. K. Mossberger (Arizona State University)

Prof. dr. S. van Thiel (Radboud University Nijmegen)

Prof. dr. R. Torenvlied (University of Twente)

Chair

Prof. dr. T. A. J. Toonen

Paranymphs

A. A. J. Konijnendijk MSc.

Dr. R. Nieuwenhuis 


\section{POLICY INNOVATION \\ IN DUTCH \\ MUNICIPALITIES}

DISSERTATION

to obtain

the degree of doctor at the University of Twente

on the authority of the rector magnificus

Prof. dr. H. Brinksma,

on account of the decision of the graduation committee,

to be publicly defended

on Thursday, December I o, 20 I 5 at I 4.45

by

Wouter Jans

born December I 5, I 983

in Breda, The Netherlands 
This dissertation has been approved by:

Promotors

Prof. dr. A. Need

Prof. dr. S. A. H. Denters

Co-promotor

Dr. M. van Gerven 


\section{CONTENTS}

Chapter I Introduction 9

Chapter 2 Mandatory innovation in a decentralized system: the 4 I adoption of an e-government innovation in Dutch municipalities

Chapter $3 \quad$ Youth policy innovation in the Netherlands: The realization $\quad 67$ of Centers for Youth and Families by municipalities

Chapter $4 \quad$ E-democracy innovation in Dutch municipalities between $2007 \quad 9$ I and 20 I I

Chapter 5 Lifting the ban on Dutch brothels: Do local social needs and local political demands matter for municipal policies?

Chapter 6 Conclusion and discussion 



\section{CHAPTER 1. INTRODUCTION'}

\section{Background and the main research question}

Since the 1980 s a series of decentralization reforms has increased the range of policy responsibilities for Dutch local government. In 2015 this range of responsibilities was further extended by major decentralizations in the social policy domain. Many tasks were transferred from the national government to municipalities. In this decentralization process, municipalities became administratively and financially responsible for three specific areas of administration: youth policy, employment and income, and care for the chronically ill and the elderly. In the coalition agreement of cabinet Rutte II (20I2-20I6) these decentralizations were justified by the argument that "The transfer of a large number of tasks from the central government to municipalities allows for local tailoring and customization, and allows for stronger citizen involvement. Municipalities can better coordinate the implementation of tasks, and thus do more with less money. To this end, the central government gives them wide discretion" (Regeerakkoord VVD PvdA, 20 I 2, p. 40). Such decentralizations considerably increase the political and administrative discretion of municipalities, and therefore they are assumed to have major implications for local governments as well as for their citizens (Van der Steen \& Van Twist, 2014). Against this background, in this dissertation we examine four decentralized policies, in order to determine how Dutch municipalities actually used their increased discretion in performing new tasks. The tendency of increased decentralization that we have just described is not unique to the Netherlands. Also in other European decentralized countries policy responsibilities have increasingly been transferred from the national government to local governments (Denters, 2005; Pollitt \& Bouckaert, 2004). Findings of this dissertation about innovation in a decentralized context might thus extend beyond its mere relevance for the Netherlands.

In the academic debate, normative theories about territorial decentralizations and central-local relations often assume that local government provides favorable conditions for innovations in governance and policy (Beetham, 1996; Pollitt, 2005). For example, Hall ( 1998 ) pointed to the fact that throughout the centuries, cities always have been the breeding grounds where major social transformations were initiated and came to fruition. In the same vein, Beetham ( 1996 , p. 38) argued that decentralization could contribute to the innovative capacity of a system of governance, because diverse solutions can produce a fertile ground for innovation and experimentation, and for different models of good practice. Deci-

\footnotetext{
${ }^{1}$ Parts of this chapter are based on: Jans, W., van Gerven, M., Denters, B., \& Need, A. (20 I 3). Innovatiekracht in Nederlandse gemeenten: naar een bestuurskundige onderzoeksagenda. Bestuurswetenschappen, 67(3), 2 I-44.
} 
sions by a higher tier of government to decentralize policy responsibilities are usually justified by the notion that local authorities are better able to tailor policies to the demands and needs of local circumstances (De Vries, 2000; Pollitt, 2005). The most appropriate and innovative solutions to local problems are therefore thought to be "devised most effectively by those who have the advantage of local information and experience, and who also have to live with the consequences of their decisions" (Beetham, i 996, p. 38). Territorial decentralization thus may in different localities lead to the formulation of different innovative responses to similar challenges. Moreover, local governments can modify these responses to specific local conditions and specific local needs.

In the allocation of tasks it has been rather easily assumed - both in the political world and in normative academic theories - that local governments, when faced with new decentralized tasks, create policies that answer to specific local priorities and local conditions. In situations like this, it is furthermore assumed that local governments function for the most part as autonomous decision-making entities. However, in the policymaking process, local governments do not function in isolation. They are being influenced vertically by decisions from the national government; and besides, it has long been recognized that there are also horizontal networks (for example, inter-municipal boards and regional policy networks) that define the space in which local governments maneuver (Denters, I98I; Gregg, I974; Walker, г 969; see also, Füglister, 20 г га; Sugiyama, 2007). In developing local policies, municipalities for example have the opportunity to learn from each other's experimentation with the various available policy solutions, by comparing the pros and cons of these different approaches systematically. Governments having the opportunity to learn from other governments' prior experiences allow local governments in a decentralized system to function as a natural test bed or laboratory for innovations in governance (Füglister, 20 г гa; Karch, $2007 \mathrm{a}$; Volden, 2006). In addition to learning there are also other reasons (economic competition, imitation, coercion, normative pressures) that may induce local governments to follow policies and guidelines developed elsewhere in adopting new local policies. This process of deliberately adopting 'new' policies developed in other jurisdictions is often referred to as a process of policy diffusion (Berry \& Berry, 2007, 20 I 4; Shipan \& Volden, 2008). Altogether, decision-making about local issues may not merely rely on local autonomy, because it "increasingly involves multiagency working, partnerships and policy networks which cut across organizational boundaries" (Denters \& Rose, 2005, p. 253). These external influences in the policy innovation process might be at odds with the development of policies to the demands and needs of local circumstances. As local policy-making is based more on standards that are developed in other jurisdictions this can be detrimental to the local customization of policies. Therefore it is important to consider whether choices in local policy-making are determined by internal local conditions or whether they are also determined by conditions external to municipalities (compare, Berry \& Berry, 2007, 20I4). Thus, whether the promises and wishes that decentralization entails, actually happen in the real world is an important empir- 
ical question. That is why, in this dissertation, we aim to gain fundamental knowledge about the autonomy of local governments in developing new policies. Our research concentrates on municipalities in the Netherlands, and their vertical relationship vis-à-vis the national government, and their horizontal relationship vis-à-vis other municipalities.

Performing decentralized tasks demands a lot from the ability of municipalities to adapt to societal and political changes. Especially important in the execution of decentralized tasks is the ability of local governments to develop innovative solutions that are appropriate and fitting in the local circumstances. These local circumstances typically vary. Therefore, we would expect that when local governments are indeed responsive to local political priorities and the needs and demands of local citizens, and when they tailor policies accordingly - as the decentralization-thesis implies - decentralization will lead to differences in local policies. These differences may pertain to variations in the timing of policy adoptions, and to differences in the content of policies. With regard to timing, one might expect that municipalities where local problems in a particular policy area are serious, or where they are a top priority on the local political agenda, will be amongst the first to actively exploit new opportunities created by the decentralization. Alternatively, municipalities where such problems are small and political priorities are different, will be less eager to exploit any new opportunities provided to them. Karch and Cravens (20 I 4) found, for example, that differences in the timing of adoption of a 'Three Strikes law' were due to conservative states with more racial diversity being earlier adopters, and states with a larger influence of important stakeholder groups opposing innovation being later innovators. With regard to differences in policy contents, for example, Sluiter (20 I 2 ) has shown that in countries that have stronger female emancipation, left-wing parties are more likely to adopt more permissive abortion policies.

There may also be reasons why in practice local priorities and circumstances are not guiding the decisions to opt for innovative policy solution. Usually, innovations involve many uncertainties, which may consequently result in local governments showing riskaverse behavior. Regarding the timing of policy adoption decisions, governments might want to wait with the realization of new initiatives until they have seen successful policy experimentations elsewhere. An example of this wait-and-see behavior by governments has been shown by Volden (2006) who found that States with successful policies were more likely to be emulated than States with failing policies. Uncertainties for governments might also have implications for substantive differences in policies between governments. Policy solutions might to a large extent show similarities, due to what are known as normative pressures (Berry \& Berry, 2007, 20 I4; DiMaggio \& Powell, ı983, I99 ; Sugiyama, 20 I2), which means that governments can be more inclined to adopt established policies due to shared norms, or because policy-solutions are widely seen and are considered socially legitimate. For example, Van Gerven and Beckers (2009) have found that due to reasons of legitimacy, 
in the vast majority of EU-countries the availability of activate labor market programs has increased from the I 990 s onwards. Nieuwenhuis (20 I 4) has shown that in the vast majority of OECD-countries the availability of paid parental leave increased between I 975 and 2005. This might indicate that countries adopting policies to increase parental leave considered these policies to be legitimate, because other countries already took similar measures. Others have argued that policies are especially more likely to spread among governments with shared characteristics, such as economic, political or cultural similarities (Brooks, 2005; Volden, 2006). It is thus by no means obvious to assume that governments create policies independently, and entirely based on local priorities and local conditions. Only when governments would utilize their potential for developing innovative solutions extensively, we would expect considerable pluriformity among governments in the timing of the adoption of their policy solutions, as well as in the content of their policy solutions.

Despite the often assumed potential for developing innovative solutions, there are several indications that often high degrees of policy uniformity are encountered while policy pluriformity had been expected (Denters, Van Heffen, \& De Jong, I 999; Gilsing, 2007; Van der Veer, Schalk, \& Gilsing, 20 I I ). A first example of a situation where pluriformity in policy decisions was expected but not found is the in 1994 in the Netherlands initiated bigcities-program (In Dutch: Grotestedenbeleid). This program was based on the assumption that a decentralized approach to urban issues would lead to policy experimentations and policy innovations (Denters et al., I 999). In practice, the policy approaches of the various cities involved in the new big-city-program were little innovative and fairly uniform, and thus the potential for policy learning was underutilized (Denters et al., I 999; Van der Laan et al., I 998). Research in the field of Dutch youth policy showed a similar picture: looking at the main emphasis of the municipal policy programs, many municipalities made similar choices (Gilsing, 2005, pp. 2 I 4-2 I 6, 2007). This finding was confirmed in research on the implementation of social policies, where municipalities in the Netherlands showed much resemblance in their policy visions (Van der Veer et al., 20 I I; Van der Veer, 20 I 3). Not only in the Netherlands, but also, for example in Brazil, a country continental in size with much diversity across municipalities in demographic composition and financial resources, there was a surprising pattern of emulation of programs that were initially designed for other cities (Sugiyama, 2008).

Given the background outlined above, we examine how innovative municipalities are in the execution of decentralized tasks, and to what extent variations in internal and external factors are important. We investigate to what extent factors, such as social needs, citizen demands, and municipal politics can account for differences in innovativeness. These factors that relate to municipalities' motivations for innovation will be contrasted with factors that pertain to municipalities' obstacles and resources for innovation, such as financial capacity, the amount of staff, and the influence of external factors such as intergovernmental networks. This allows us to explicitly link normative expectations about decentralization to 
the empirical question, whether municipalities actually develop policies based on local priorities and local circumstances. In this dissertation we will therefore answer the following main research question:

To what extent do differences exist among Dutch municipalities in their execution of decentralized policy responsibilities, and which factors can explain these differences?

\section{Innovation research and the sub-questions}

By answering the question about differences in the execution of new decentralized policies, we address the innovativeness of municipalities in performing these new tasks. Therefore, we start with defining our concept of innovation. Following Walker ( 1969, p. 88 i), and others (Berry \& Berry, I 990, 2007; Gray, I 973) we use a straightforward definition of innovation. Something is labeled an innovation when it concerns a policy, program, working method, regulation, law, or an activity that is new to the administrative unit under investigation (here, a municipality), no matter how old the relevant program may be, and no matter whether it has been introduced elsewhere previously.

Governments' innovativeness is thus considered as the actual introduction and realization of new initiatives or new policies. In the just formulated main research question we are interested in the factors that influence municipalities' innovation decisions. By investigating factors that are important for innovation we build on previous work and we also set some new accents. Previous research has traditionally been interested in the answer to the question what local characteristics can explain differences in the variation of innovativeness across governments (Boehmke \& Skinner, 20 I 2; Walker, I 969). In studying variations in policy innovation by governments, scholars tend to focus on innovations that are adopted as a result of a process of voluntary decisions (for example, Berry \& Berry, 2007; Graham, Shipan, \& Volden, 20 I 3; Rogers, 2003). Political actors are in these instances considered independent in terms of decision-making, thus free to decide for themselves whether or not to adopt a certain innovation. Even though the decision to adopt an innovation can be voluntary, governments can still influence each other's policy innovation decisions. When policy innovations are adopted because they have diffused among governments, this process is usually characterized as uncoordinated interdependence (Elkins \& Simmons, 2005). It is called 'uncoordinated' because adoption decisions are voluntary, and it is called 'interdependent' because later adoption decisions are assumed to be influenced by prior adoption decisions of other governments. However, it happens that governments do not have a voluntary choice to adopt a certain policy. Quite often, local governments are mandated by central government to adopt innovations. This occurs, for example, when polices are decentralized from the national government to local governments - as we referred to in the introduction of this chapter. These decentralizations mandated by higher tier governments are regarded to 
bring an end to the diffusion process, because it leaves local governments no choice but to adopt the innovation (Karch, 2006, p. 406). Some have therefore described the results of this national government interference as a "highly uninteresting form of diffusion, as nearly all state discretion is eliminated by national-level fiat" (Berry \& Berry, 2007, p. 23 I). We argue, however, that one cannot presume that local governments are more or less unresisting executors of central directives. At least they have some discretion in performing their mandatory tasks (Goldsmith \& Page, 20 I o; Goldsmith, 2005; Toonen, I 987). Often, national initiatives allow local governments at least some room to determine whether, how and when they come into action (Soss, Schram, Vartanian, \& O’Brien, 200 I). Thus, governments can still have discretion regarding the timing of the adoption of the innovation and the extent to which they innovate in content. It is important to consider how policy innovations are shaped under these conditions of decentralization of policy responsibilities. This is especially true for the Dutch administrative context where municipalities are often required to execute decentralized tasks. Therefore, in this dissertation we investigate two voluntary innovations, and two mandated innovations.

In the selection of research cases we have not only given a central place to the distinction between voluntary and mandated innovations, but made another important distinction, namely that between different types of policies. It has been recognized that making a distinction between different types of policies is necessary, because the impact of certain factors explaining differences in levels of innovativeness can be different depending on the type of policy that is being examined (Gray, I 973; Makse \& Volden, 20 I I). Furthermore, it has been argued that understanding differences in policy attributes is fundamental to achieving an increased understanding of policy adoption processes (Makse \& Volden, 20 I I). By testing similar hypotheses pertaining to the effects of different factors on the timing and content of policy innovations in different policy domains, we can compare the relative power of for example economic and political factors in determining differences in innovativeness (Hwang \& Gray, I 99 I, p. 277). Hwang and Gray ( I99 I) found that governments' political ideology mattered for spending in welfare policies, but not for highway and education policies. They also found that organizational (fiscal) capacity was an important determinant of state spending in all three policy areas. Furthermore, patterns of innovativeness for morality policies are argued to be different from those for other policies (Mooney \& Lee, I 999; Sluiter, 20 I 2). In comparing the temporal adoption patterns of morality and non-morality policies, Sluiter (2012) has shown that these different types of polices have considerably different temporal patterns. Temporal patterns for the spread of moral innovations are regarded to deviate from temporal patterns of other policies because of their stronger visibility, their relatively low technical complexity, and their relatively high salience to the public and to politicians (Mooney \& Lee, I 999). 
In this dissertation we distinguish between administrative policy innovations and political policy innovations, because we want to explore the possibility that the answer to our main research question is different for each type of policy (compare, Berry, I 994). Investigating differences in innovation processes of administrative and political innovations is interesting given the findings of earlier research as mentioned above (see: Hwang \& Gray, I 99 I; Makse \& Volden, 20 I I; Mooney \& Lee, I 999; Sluiter, 20 I 2). The administrative innovations that we investigate are about reforming administrative practices and governmental processes in order to achieve more efficient or more effective policy or political goals. We investigate two cases of innovations in e-government, which we consider to be administrative innovations (compare, McNeal, Tolbert, Mossberger, \& Dotterweich, 2003). The political innovations that we investigate are adopted and implemented to achieve policy or political goals aimed at preventing or solving societal problems. They are about what politics is considered to be about, namely the "authoritative allocation of values for the whole society" (Easton, I 953, p. I 29), and "who gets what, when, and how" (Lasswell, I 950). Decisions to opt for one particular innovative policy solution or the other are in these instances dependent on normative choices between different conflicting values and often have direct and important implications for the daily lives of citizens. We investigate two political innovations that "seem to have altered (or promise to alter) the lives of persons affected by them in substantial and fairly permanent ways" (Polsby, 1985, pp. 7-8). One innovation is about the legalization and regulation of prostitution, and the other innovation is aimed at increasing the wellbeing of youth and youngsters.

In this dissertation four case studies are conducted where Dutch municipalities adopt innovations. We have created a fourfold categorization by combining the distinction between administrative and political innovations with the previously introduced distinction between voluntary and mandated innovations. Table i shows our categorization of the four cases under study in this dissertation. It shows the subdivision in research cases investigating mandated or voluntary policies, and the subdivision in administrative or political policies. For each of the four categories we have selected one policy innovation to investigate. Between parentheses in Table I are the individual chapters in which the particular innovations are being examined. We are well aware that we have created an ideal-typical classification. Of course, all four our innovations lie somewhere on the administrativepolitical policy continuum, and also the four innovations are in varying degrees mandatory or voluntary. However, by using the fourfold distinction of policies it is possible to examine to what extent the answer on the explanatory part of our research question is different (or similar) for each of the four different categories. In the four different chapters we either examine differences in innovativeness by explaining differences in the timing of the adoption of an innovation, or by explaining differences in the content of an innovation. There are relatively few possibilities for municipalities to vary in the content of the policy when its adoption is mandatory. For the mandated innovation we therefore concentrate on the timing 
of the adoption of the new policy. In these instances municipalities are considered more innovative when they adopt this new policy earlier (Berry \& Berry, I 990; Rogers, 2003). Following the early work by Berry and Berry ( I 990), in Chapter 2 and Chapter 3 of this dissertation we focus on explaining differences in the timing of adoption decisions.

Table 1. Four studies into municipal innovativeness by types of policy.

\begin{tabular}{lcc}
\hline & Administrative & Political \\
\hline \multirow{2}{*}{ Mandated } & E-government & Youth and Family \\
& (Chapter 2) & (Chapter 3) \\
Voluntary & E-democracy & Prostitution \\
& (Chapter 4) & (Chapter 5) \\
\hline
\end{tabular}

For voluntary innovations the possibilities to vary in policy-content are larger than for mandated innovations, and therefore in these cases it is important to investigate substantive policy variations. Innovative policies can in these instances take on a variety of forms in the municipalities in which they are enacted. Substantive differences in policy content may manifest themselves, for example, in more or less comprehensive packages of policy measures, in more or less ambitious policy goals, or in more or fewer policy objectives. Municipalities that develop more extensive policy programs are considered more innovative than municipalities that show less comprehensive policy development (Clark, I985). In Chapter 4 and Chapter 5 of this dissertation, following others (Clark, I 985; Hays, I 996; $\mathrm{McNeal}$ et al., 2003) we focus on the content of the policy innovation by investigating substantive differences in the policies adopted in different municipalities. Next, we will shortly discuss our four research cases, and our four specific sub-questions.

\subsection{Sub-questions about mandated innovations}

Chapters 2 and 3 of this dissertation pertain to the study of mandated innovations. In Chapter 2 we study the factors affecting the adoption of a mandated administrative e-government innovation: the Basic Registration Addresses and Buildings (BAG). Electronic government (e-government) usually refers to "the delivery of government information and services online through the Internet or other digital means" (West 2004: I 5). As for the case we study, innovations in e-government are often aimed at improving online services for citizens and businesses. In August 2008, the Dutch States-General mandated that from July ist 2009, all municipalities must have been connected to the nationwide BAG facility. Dutch municipalities were made responsible for collecting and sharing information about all addresses and buildings within their borders with a nationwide database (VROM, 2009). This database was created to share up-to-date information about all addresses and buildings in the Nether- 
lands with government institutions and public services, but also to share information with public services and private companies. We examine differences between municipalities in the moments that they have met the nationally set requirements and were connected to the national database. Our first sub-question reads: ( I ) To what extent do differences exist among Dutch municipalities in the timing of the adoption of $B A G$, and (2) which factors can explain these differences?

In Chapter 3 of this dissertation we study the factors that determine differences in the timing of the realization of a mandated political policy: a Center of Youth and Family (CYF). This political innovation is aimed at solving a social problem by means of improving the quality and accessibility of welfare services. The interests of the Dutch national government to have municipalities realize a CYF were to increase the quality of youth care and to increase the collaboration between different partners involved in youth care, and to provide easily accessible parenting advice and support for all families (J\&G, 2007; Van Eijck, 2006). In a letter sent from the Ministry for Youth and Family to all municipalities in November 2007 , it was announced that municipalities were made responsible for the realization of a CYF within their borders. Municipalities were expected to have realized a CYF before the end of the year 20 I I (J\&G, 2007). We examine differences between municipalities in the timing of the realization of a CYF. Our second sub-question reads: ( I) To what extent do differences exist among Dutch municipalities in the timing of the realization of a CYF, and (2) which factors can explain these differences?

\subsection{Sub-questions about voluntary innovations}

Chapters 4 and 5 of this dissertation pertain to the study of voluntary innovations. In Chapter 4 we study a voluntary administrative innovation: electronic-democracy (e-democracy, which is part of the wider field of e-government). E-democracy innovations are developed to provide citizens with access to digital information about political processes and policy choices, as well as to promote and enhance online public participation by citizens (Ahn, 20 I I; Calista \& Melitski, 20 г 3; Kim \& Lee, 20 г 2; Kolsaker \& Lee-Kelley, 2007; Lee, Chang, \& Berry, 20 I I; Scott, 2006; Yun \& Opheim, 20 I०). Municipalities have a general power of competence to decide to become active in the development of e-democracy applications. There is no national legislation that requires them - or prohibits them - to participate in the development of these applications. Municipalities thus have considerable discretion in developing local e-democracy applications. We examine the extent and reasons for differences in municipalities' e-democratic developments. Our third sub-question reads: ( I) To what extent do differences exist in the extent of e-democracy development on Dutch municipalities' websites, and (2) which factors can explain these differences?

Finally, in Chapter 5 of this dissertation we study a voluntary political innovation: the lifting of the brothel ban. From October i ${ }^{\text {st }} 2000$, prostitution in the Netherlands was legal- 
ized, and municipalities were from that moment on responsible for prostitution policy within their own borders. Although almost all municipalities adopted legislation to regulate prostitution, they could also decide not to develop local prostitution policy. Municipalities were not allowed to prohibit prostitution, but they were allowed considerable discretion regarding the content of local prostitution policy. To guide municipalities in the development of local prostitution policy, the Dutch association of Municipalities (In Dutch: De Vereniging van Nederlandse Gemeenten (VNG)) provided a 'model legislation.' This situation offered an excellent opportunity to investigate the factors that lead municipalities to alter a policy template. Our fourth sub-question therefore reads: ( I) To what extent do differences exist between Dutch municipalities in the amount of adaptations in the content of a prostitution model-regulation, and (2) which factors can explain these differences?

\section{What is new about this research?}

In this section, we shortly give an overview about what is new in this dissertation, and to what knowledge we add by answering our research questions. In this dissertation we make four contributions to the literature:

I. We broaden the empirical domain of innovation studies by studying the adoption of new polices in the context of Dutch local government. By doing so we are the first to take into account external explanations for differences in innovativeness among all Dutch municipalities (sub-section 3.I).

Moreover, substantively:

2. We add to the theoretical and practical decentralization debate by testing the decentralization-thesis against an alternative explanation (sub-section 3.2).

3. We add to the literature by studying whether explanations that affect innovativeness are robust when we compare different types of policy innovations (sub-section $3 \cdot 3)$.

4. We add to the literature by not only investigating differences in innovativeness that are based on the timing of innovation adoptions, but also by investigating differences in innovativeness that are based on the content of innovations (sub-section $3 \cdot 4)$.

In the following four subsections we discuss each of these contributions at somewhat more length.

\subsection{Progress in the selection of the empirical domain}

First, we add to the literature by broadening the scope of existing research by studying innovations in the context of Dutch local government. Research into policy innovations has been concentrating primarily on cross-national differences including research among European 
countries (Baturo \& Gray, 2009; Bol, Pilet, \& Riera, 20 I 5; Gerven, Vanhercke, \& Gürocak, 20 I 4; Gilardi, 2008, 20 го; Lee et al., 20 I г; Lee \& Strang, 2006; Levels, Sluiter, \& Need, 20I4; Sluiter, 20I2; Toshkov, 20I3) and Latin-American countries (Sugiyama, 20I I; Weyland, 2005, 2009), or on research across countries world-wide (Brooks, 2005, 2007; Calista \& Melitski, 20 I 3; García-Sánchez, Rodríguez-Domínguez, \& Gallego-Álvarez, 20 I I ; Lee et al., 20I I; Rodríguez Domínguez, García Sánchez, \& Gallego Álvarez, 20 I ; Simmons \& Elkins, 2004). At the subnational level, the focus is on the study of innovations in federal states, which almost always consists of American research into differences in innovativeness among the American States (Allard, 2004; Balla, 200 I; Baybeck, Berry, \& Siegel, 20 I I; Berry \& Berry, I 990; Boehmke \& Skinner, 20 I 2; Boehmke \& Witmer, 2004; Boushey, 20ı ; Glick \& Hays, ı 99 I; Gray, ı 973; Jensen, 2004; Karch, 2007a; Makse \& Volden, 20 I I; McNeal et al., 2003; Mintrom, ı 997; Nicholson-Crotty, 2009; Shipan \& Volden, 2008; Taylor, Lewis, Jacobsmeier, \& DiSarro, 20ı 2; Tolbert, Mossberger, \& McNeal, 2008; Volden, 2006; Walker, I 969). However, some research has also been done among the federal Cantons in Switzerland (Füglister, 20 г га, 20 г гb; Gilardi \& Füglister, 2008). Outside the United States, studies examining differences in policy innovativeness in decentralized government systems are relatively sparse. There has been research among local governments in, although not limited to, Brazil (Sugiyama, 2008, 2012), the United Kingdom (Boyne, Gould-Williams, Law, \& Walker, 2005; Walker, Avellaneda, \& Berry, 20 I I; Walker, 2006), the United States (Krause, 20 I I), and Denmark (Hansen, 20 I I). Moreover, available subnational studies are heavily concentrated in the domain of egovernment innovations (Ahn, 20 I I; Moon, 2002; Norris \& Moon, 2005; Weare, Musso, \& Hale, i 999).

The empirical cases that we study in this dissertation are of interest to the study of innovations, because we can critically assess the general validity of theoretical expectations that have foremost been assessed in the U.S. federal system. We will test theoretical expectations that have been mainly applied to explain differences in innovativeness among the American States, but we will do so among Dutch municipalities. Although there are vast differences between the U.S. federal system and the Dutch decentralized unitary state, an important commonality between both countries is that they allow their local governments a considerable amount of discretion. Both systems stimulate and in potential allow for economic, political, and social diversity across localities in organizing their own government and administration.

If we focus on innovation research in the Netherlands specifically, we can conclude that differences in innovativeness among municipalities have been largely uncharted. Only a few explanatory innovation studies have been performed among Dutch municipalities. For example, Homburg and Dijkshoorn (20II) showed that the presence of personalized egovernment services in municipalities could be explained by a larger organizational capaci- 
ty, and not by political ambitions related to e-government innovations (as expressed in municipal coalitions' four-year program plans). Van der Graft and Svensson (2006) found that the extent e-democracy development in municipalities was positively related to problem severity, as indicated by a low electoral turnout during local elections, and to organizational expertise, as indicated by their performance in electronic service (e-service) delivery. Moreover, the extent of e-democracy development was not related to citizen demands, and also not related to differences in political ideology between municipalities. A final example, Van Loon and Toshkov (20 I 5) found that the degree of open source software (OSS) adoption by municipalities was determined to a large extent by the presence of policy advocates and the extent of political commitment, and not by organizational capacity.

Besides the already mentioned descriptive studies (Denters et al., I 999; Gilsing, 2005, 2007; Van der Laan et al., ı 998; Van der Veer et al., 20 I i; Van der Veer, 20 I3), more small- $N$ innovation research has been performed in the Netherlands. Fleurke and colleagues (Fleurke, Hulst, \& Vries, I 997; Fleurke \& Hulst, 2006) answer in their studies, among other questions, the question to what extent municipalities use their greater policy discretion to adapt policies to the local conditions. They found that the high expectations about the effects of decentralization - that decentralization measures would improve the performance (more effective and efficient) of the administrative system and also improve the functioning of local democracy - were not achieved. Korteland (20 I 0 ) examines municipalities in depth by means of case-study research in her dissertation about innovations in the policy areas education, and public safety. She found that the willingness of municipalities to adopt a Community School and/or a Safety House was more likely, when the functional, political as well as institutional meanings attached to these innovations increased. Additionally, in the Netherlands some research among Dutch municipalities took place into the diffusion of electronic service delivery innovations, and New Public Management (NPM) innovations. Homburg and colleagues (Homburg, Dijkshoorn, \& Thaens, 20 I3) found that for the diffusion of electronic service delivery innovations among io Dutch municipalities, external persuasive institutional pressures - both vertical and horizontal - were more important than internal technological opportunity and cost-benefit considerations. Van Helden and Jansen (2003) showed in a literature study, that ideological and instrumental NPM-innovations were considerably present in Dutch municipalities, but that the actual use and impacts of performance information for planning and control, as well as for evaluation of managers, was limited.

The Dutch studies that we have presented above have only focused on internal explanations for innovation - such as economic, political, and social determinants. They did not take into account external explanations for the differences in innovativeness among municipalities (exeptions are, Homburg et al., 20 I 3; Korteland, 20 го). Since the landmark study by Walker (1969), the hypothesis that innovations diffuse across governments because governments influence each other when it comes to adopting and implementing new policies 
has been tested and confirmed in many different settings. In this dissertation, we test this hypothesis for the first time for all municipalities in the Netherlands.

\subsection{Progress by testing the decentralization-thesis}

As we already indicated in the introduction to this chapter, the decentralization-thesis is a central doctrine in political and scientific debates on the merits of territorial innovations. This hypothesis implies that as a consequence of decentralization subnational governments will be better able to take decisions about the development of policies based on local needs and demands, and on differences in political priorities then when policies would be executed centrally by the national government. To the extent that this is the case it is to be expected that differences in new policies adopted after the nationally initiated reforms should reflect differences in relevant local factors, such as the severity of local problems, and differences in local political demands. In this dissertation we will empirically test this presumption and will also look into alternative explanations (to be discussed later on in this chapter). We will do so by a systematic investigation of the factors that can explain variations in local government innovations. Hereby looking into the effects of factors that pertain to differences in local problems, needs and demands, and other possibly relevant factors (compare, the explanatory part of our main research question).

\subsection{Progress by studying different types of local government innovations}

In studying policy innovations in Dutch local governments we will compare the answers that we find for different types of innovations when asking about the factors that influence patterns of local innovations. As shown in Table I, we have selected four local government innovations on the basis of two dimensions, namely the distinction between ( I ) voluntary and mandated innovations, and the distinction between (2) political and administrative innovations. By comparing explanations for differences in innovativeness across these different types of policies it is possible to examine the general validity of theoretical explanations of local government innovativeness.

\subsection{Progress by studying differences in timing and differences in con- tent}

Finally, we also add to the literature by investigating both the timing of adoptions of innovations, and by investigating the content of innovations. As we have already argued in the introduction section, it is important to investigate differences in innovativeness by addressing differences in the timing of policy adoptions, and also by addressing differences in policy 
content. In previous research there predominantly has been a focus on explaining differences in the timing of adoptions (Berry \& Berry, 2007; Karch, 2007b). Besides this interest in temporal innovation patterns, it is also important to consider which substantive decisions were made by adopting governments. Here the question is whether municipalities tailor the content of new policies to specific local conditions, and local needs, or whether they more or less blindly copy examples from elsewhere. This question is - even in the United States that is considered to be the most important place for innovation research - rather under addressed. Clark (1985) was the first to observe that in innovation research, the emphasis has been rather exclusively on the timing of adoptions. She argued that a greater focus on substantive issues is important: "One might argue that the major problem of this research tradition is that it reveals nothing about the content of new policies. Its fascination is with process, not substance" (Clark, I 985, p. 63). More than twenty years later, the situation has not changed much in this respect (Karch, $2007 \mathrm{~b}$ ). A focus on different phases in the innovation process - besides the policy adoption phase - is especially helpful to isolate which specific factors are more likely to be influential in different phases of the innovation process (Karch \& Cravens, 20 I I). Thus, besides a focus on timing, a stronger focus on policy content is particularly important, because - as already explained - the success of decentralization and the functioning of local government as a testing bed or laboratory of innovations stands and falls with the extent to which the content of policy innovations is determined by local conditions. Again, the added value of our study is that it allows drawing conclusions about the robustness of explanations for differences in levels of municipalities' innovativeness for different measures of innovation. To do so, we investigate differences in innovativeness in terms of timing for the mandated innovations, and differences in content of the innovations for the voluntary innovations in our dissertation.

\section{Answering the research questions: Describing the empirical reality}

To answer our questions about the timing and content of the innovations, for both the first (descriptive) part of our research questions, and the second (explanatory) part of our research questions we need individual municipal level data. First, we need individual municipal level data to describe differences in innovativeness of the local government system as a whole to determine whether there are differences among governments in their levels of innovativeness. This allows us to answer our descriptive questions about the extent to which there are differences in levels of innovativeness among the total population of municipalities. Second, if we have found differences among municipalities in timing or in content of the particular policy under investigation, it is important to analyze whether these differences can be attributed to differences in municipalities' internal and external characteristics. These municipal level analyses are aimed at answering explanatory questions, 
about which factors can explain when (timing) and to what extent (content) municipalities have decided to innovate in a particular policy.

\subsection{Describing differences in timing of innovations}

To answer the first (descriptive) part of sub-questions I and 2, respectively in Chapter 2 and Chapter 3, we use comparable methods to describe differences in timing as we are explaining below. Studies focusing on the timing of innovations have typically focused on the voluntary adoption of polices, in which the cumulative number of innovations over time is normally characterized by an s-shaped learning curve (Rogers, 2003). Rogers (2003) pointed out that if one follows the innovation process over time, the number of organizations that innovate is initially limited to a small number of adopters. After a number of pioneers has taken the lead, first, a few early adopters follow, who are in turn followed by the early majority, and then by the late majority. Finally, there are the late adopters. On the basis of this temporal distribution pattern, which usually follows a normal distribution, Rogers $(2003)$ formulated the hypothesis that over time the cumulative number of units in the population that has carried out the innovation follows an s-curve (see Figure i).

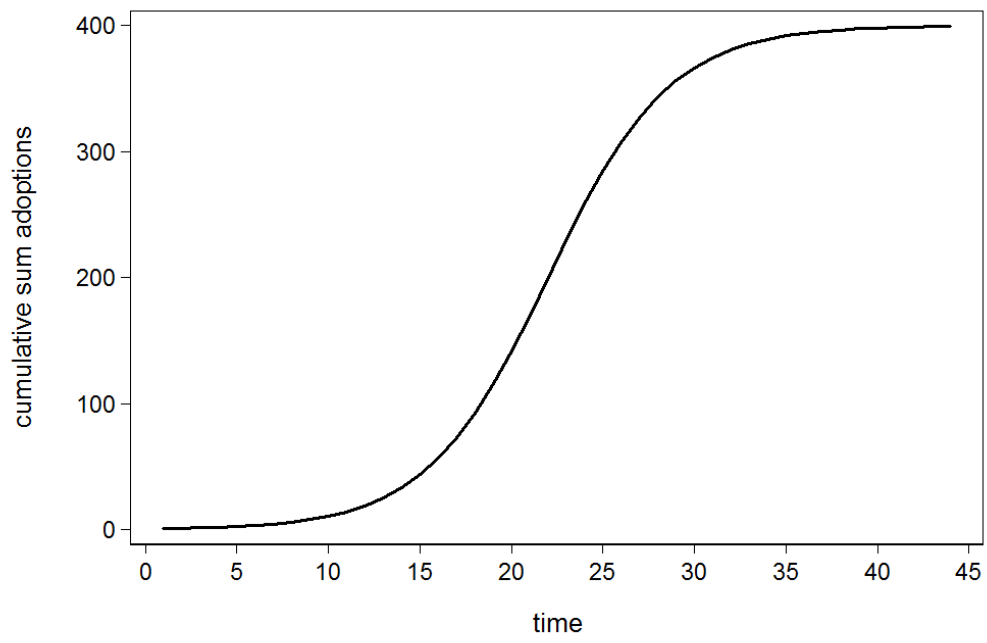

Figure 1. Example of an s-curve for the cumulative number of adoptions over time.

This phasing of the cumulative number of adoptions over time and the corresponding scurve has been reproduced in many studies (Elkins \& Simmons, 2005; Gray, I 973; Mahajan \& Peterson, I985; Mooney \& Lee, I995b, r 999; Simmons, Dobbin, \& Garrett, 2008; Sluiter, 20I2; Weyland, 2005). Nevertheless, there is both empirical and theoretical evi- 


\section{CHAPTER ONE}

dence (Boushey, 20 Iо; Calista \& Melitski, 20 I 3; Henrich, 200 I; Mooney \& Lee, I 995b, I 999; Sluiter, 20 I2) that depending on for instance the nature of the innovation, the temporal pattern sometimes has a different shape. This is notably the case for the adoption process of political innovations, such as moral laws and moral policies (Mooney \& Lee, I 995b, I 999; Sluiter, 20 I 2). These types of policies show different temporal patterns: innovation research in such domains noted that a large number of organizations or governments adopted a new form of politically controversial regulation in a relatively short period of time. After the initial steep increase of adoptions, the number of organizations that adopted the innovation quickly decreases, and some organizations do not innovate at all. If we observe the corresponding cumulative frequency distribution then there is not the classic s-curve, but rather an r-curve (Boushey, 20 I o; Mooney \& Lee, I 995b, I 999; Sluiter, 20 I 2), see Figure 2 .

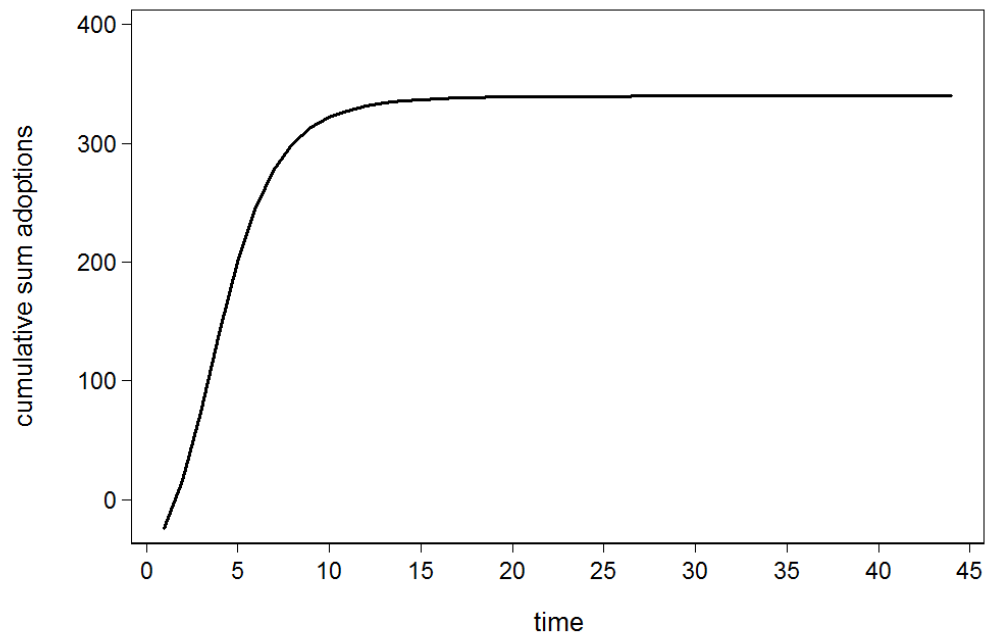

Figure 2. Example of an r-curve for the cumulative number of adoptions over time.

The s-curve and the r-curve are two cumulative distributions of adoptions over time that are based on specific theoretical considerations, and that are most likely only to be found when the conditions of the policy under examination exactly comply with the conditions set by the theory. Although in many instances cumulative distributions have been found that do - at least to some extent - resemble an s-curve or an r-curve, it is quite rare when the empirical distribution exactly corresponds with the theoretically expected pattern. There are many studies that show that the empirical distributions of adoptions over time take only to a certain extent these ideal-typical forms (for example, Boushey, 20 I o; Gray, I 973; Maggetti \& Gilardi, 20 I 4; Mooney \& Lee, I 999; Sluiter, 20 I 2). Whatever the exact shape of the cumu- 
lative pattern of adoptions, the goal in the before mentioned studies is to explain differences in the timing of innovations. As for all empirical research, it is only possible to explain differences when there are differences.

\subsection{Describing differences in content}

For the first (descriptive) part of our sub-questions about differences in the content of the innovation - sub-questions 3 and 4 in respectively Chapter 4 and Chapter 5 - it is also useful to describe variation in innovativeness among innovators. When researchers want to explain the timing of innovations it is common practice to describe differences in individual adoption decisions by either graphing a cumulative adoption curve or by showing a table with the major events and timelines. Both methods can be used to show variation between individual governments central to the analysis. For describing the content of policy innovations there is no such common practice to describe variation between individual governments. In research practice, different well feasible methods have been applied to describe differences in the content of innovations. For example, a study focusing on egovernment innovation in de U.S. States presented their dependent variables: the percentage of a state's government websites that offer at least one e-government service, and a second dependent variable which is a measure of the overall state ranking of government websites (McNeal et al., 2003). Others have presented their dependent variable for a selection of countries ( 32 from the I 89 countries in their analyses) (García-Sánchez et al., 20 I I), which is an index score that represents the quality and relevance of e-participation (a form of e-government) initiatives for countries all around the world. Furthermore, Boehmke and Skinner (2012) presented an innovativeness score for all U.S. States in their research based on i 89 policies that diffused since i 959. A last example comes from Glick and Hays ( I 99 I) who presented for all U.S. States in their analyses the comprehensiveness of an innovation by calculating a reinvention score of living will laws; a higher score indicates a less restrictive law. For similar reasons why temporal patterns of innovations are described, giving a description of the variation in the content of the innovation gives important understanding about what is being explained. In Chapter 4 of this dissertation we describe differences in innovation in content only to a limited extent, but in a conventional manner. In Chapter 5 , however, we have experimented with a totally new way of operationalizing the content of an innovation.

\section{Answering the research questions: Explaining the empirical reality}

In this section we describe how we aim to explain differences in innovativeness among municipalities. Such an explanation presupposes that we are able to understand if local priorities and local conditions determine why some municipalities belong to the pioneers, 
and why others are slower innovators, and why some municipalities adapt the content of new policies more extensively than others. In this dissertation, we assume methodological individualism, which means that we consider a municipality as one undivided actor and decision-maker (Scharpf, I 997). We thus abstract from the dynamics of intra-municipal decision-making and treat the organization as a unitary actor, which acts on its own. This means that individual membership of politicians in a policy network is attributed to the municipality as undivided actor, and is considered to be a characteristic of a municipality instead of a characteristic of an individual within a municipality. Likewise, the ideology of the mayor and aldermen is not considered a characteristic of these individuals, but is considered as feature of their municipality.

To explain variations in municipalities' levels of innovativeness - whether these are variations in timing or variations in content of the innovations - we derive predictions from rational choice theory. Our rational choice approach assumes that actors conduct activities that are, given the circumstances, best in line with respect to their preferences and desires (Hedström, 2005, p. 6 I). We do not assume that all municipalities "act in an entirely rational manner: only that the tendency to act rationally, in the circumstances that prevail, is the common factor at work" (Goldthorpe, i 996, p. i I 5). From these basic assumptions about rational decision-making we derive hypotheses in terms of factors that contribute to differences in innovativeness. In line with rational choice theory, and following Mohr ( I 969), and Berry and Berry (2007), we assume that motivation and resources are positively related to innovation, and that obstacles are negatively related to innovation. This brings us to our most general hypothesis that will be tested throughout this dissertation: When municipalities are strongly motivated, when the obstacles they encounter are low, and when they have more resources available, they will be more innovative than if the exact opposite is true.

The three factors - motivations, obstacles, and resources - that we presume to be important for being innovative or not, may be affected by internal political, economic, and societal conditions, along with external conditions, such as the influence of inter-municipal regional networks or professional networks (Berry \& Berry, 2007; Karch, 2007a). Central to investigating these internal and external factors is whether innovation - as the decentralization-thesis implies - is the result of motivations, such as factors that pertain to differences in local problems, needs and demands, or that innovation happens as a result of the absence of obstacles and the presence of resources. Referring to factors that are both internal and external to municipalities was devised by Berry and Berry ( 1990 ), and after its initial introduction it has been widely applied by other researchers in different settings (Boehmke \& Witmer, 2004; Walker, 2006). Although we make an explicit distinction between internal and external factors in our research, we accommodate both factors under Mohr's (1969) three denominators. In each empirical chapter in this dissertation we will specify relevant motivations, obstacles, and resources for each specific policy. We will now shortly discuss which factors we include under the three attributes of innovation that we have distinguished. 


\subsection{Motivations}

Municipal governments may come up with innovative policies, or with changes to existing policies because they have a strong motivation to do this (Berry \& Berry, 2007; Mohr, I 969). In the context of rational choice theories a distinction between so-called policy-seeking motivations, and so-called office-seeking motivations has often been made (for example, Adams \& Somer-Topcu, 2009; Braun \& Gilardi, 2006; Budge \& Laver, I 986; Robertson, I 976; Somer-Topcu, 2009; Ware, I 992). Policy-seeking parties are primarily concerned with the successful enactment of polices, whereas vote-seeking parties are especially motivated to attract sufficient numbers of votes to secure office for a next election term. According to the decentralization-thesis these motivations should be the main factor determining innovation decisions. If the decentralization-thesis holds, governments are either motivated by the presence of severe local problems, or by local need and demands, or by differences in political priorities. When obstacles and resources (to be discussed later on) are more important this means that the decentralization-thesis does not hold. In the next sub-sections we will first describe what we consider to be policy-seeking motivations, and then we will describe what we consider to be vote-seeking motivations.

\section{Policy-seeking motivations}

Policy-seeking motivations can be subdivided in motivations that come from the desire of politicians to provide adequate solutions for local problems, or to provide solutions that are in line with the demands or needs from citizens, and policy-seeking motivations to innovate may also come from the ideological stance regarding the particular policy under consideration. First, when there is a severe societal condition or societal problem, policymakers' and politicians' motivations to adopt an innovation are assumed to be higher (Daley \& Garand, 2005; Sapat, 2004). For example, Daley and Garand (2005) found that if States in the U.S. had more severe hazardous waste problems, that they were more likely to adopt more stringent hazardous waste programs. Next to societal conditions, political and citizen demands provide additional policy-seeking motivations that can be of importance. For example, Walker (2006) found that local authorities were more likely to adopt new services and new groups of services when users themselves demanded these services. Moreover, political demands can be of importance. Especially when it comes to investigating political innovations it has been expected that political responsiveness to public opinion has a positive impact on the enactment of policies (Haider-Markel \& Meier, I 996; Mooney \& Lee, 2000). For example, Meier and Johnson (I990) found that when there was a predominant conservative public opinion in a U.S. state, that a state's alcohol policies to regulate alcohol consumption were more lenient towards punishment than towards treatment. Third, policy-seeking motivations may also come from the ideological positions endorsed by local policy-makers. Such ideological orientations color the perception of local problems, and affect ideas about opti- 
mal solutions to these problems (Daley \& Garand, 2005; Makse \& Volden, 20 I I). For example, Makse and Volden (20 I I) examined the adoption of 27 criminal justice policies, and found strong evidence of conservative governments advancing conservative policies, and liberal governments adopting liberal policies. Likewise the ideological orientations of key local officeholders can influence innovation adoption decisions. It has been argued that policy entrepreneurs or policy advocates - by putting energy in bringing new ideas to the attention of policymakers or politicians - can play a critical role for the implementation of new policies (Berry \& Berry, 2007, p. 237; Mintrom \& Norman, 2009). For example, Balla (200I) found that the presence of policy advocates in a U.S. state, influences the likelihood of the adoption of the Health Maintenance Organization (HMO) Model Act.

\section{Vote-seeking motivations}

Besides having strong policy-seeking motivations that may increase the chances of policy innovation, local politicians may also be motivated by the desire to attract votes for the next elections. A vote-seeking motivation that has often been connected to the extent that governments show innovative behavior is political competition (García-Sánchez et al., 20 I I; $\mathrm{McNeal}$ et al., 2003). Political competition is assumed to enhance governments' innovativeness because local politicians assume that adopting and implementing new policies will increase their electoral support (Berry \& Berry, 2007; García-Sánchez et al., 20 I I). For example, Mooney and Lee ( 1995 b) have shown that greater political competition was actually a constraint for reform on abortion policy, indicating that the political stakes are high when it comes to the adoption of morality policies.

\subsection{Obstacles}

In addition to motivation, obstacles are a second factor that Mohr ( I 969) assumed to be of importance for the innovation efforts of governments. Obstacles are assumed to hinder the adoption and implementation process of new policies, because when obstacles are high the opportunities for governments to innovate are more likely to decrease (Berry \& Berry, 2007; Mohr, I 969). An often hypothesized obstacle is the political fragmentation of a government (Allen, 2005; Brooks, 2005; Haider-Markel \& Meier, I 996; Mooney \& Lee, I 995a; Tolbert $\& \mathrm{McNeal}, 2003$ ), because a more fragmented and political arena hampers the opportunities for innovation. Even when a potential policy innovation is not a politically salient issue, political fragmentation is still assumed to hinder the adoption and implementation process because taking decisions in itself can be difficult when politicians are from different political backgrounds (Tolbert \& McNeal, 2003). For example, it has been found that U.S. states with less political fragmentation were more likely to have strict sanction policies for citizens who do not comply with new welfare initiatives (Soss et al., 200 I). Another obstacle that has 
been assumed to determine differences in innovativeness across governments is the complexity of the implementation process of the innovation (Rogers, 2003). For example, Makse and Volden (20 I I) have shown that more complex policies tend to spread more slowly than less complex policies. For a particular innovation, the complexity of implementing an innovation may also differ from one jurisdiction to another. Objective differences in for example physical conditions (like population density, soil conditions, or the absence or presence of mountains) may make innovations more difficult to implement in some places than in others. Likewise, subjective differences in perceptions of innovation related complexities might result in differences in the likelihood of innovation decisions.

\subsection{Resources}

The last factor of Mohr ( 1 969) refers to the amount of resources a government has available for innovation. Differences in innovativeness across governments depend on differences between governments in their command over financial, human, and social resources (Berry \& Berry, 2007).

\section{Human and financial resources}

It has been often assumed that larger organizations have greater command over financial and human resources and are therefore more capable of adopting and implementing innovative practices (Ahn, 20 I i; Walker, i 969; Weare et al., i 999). For example, Musso, Weare, and Hale (2000) found that municipalities in California that adopted a website had larger populations, and also had significantly higher levels of government spending and revenues. Also, Dahl and Hansen (2006) found that Danish municipalities with greater organizational capacity were more likely to adopt an innovative organizational standard: the Common Language Standard (CLS). Besides organizational capacity, organizational expertise is also often hypothesized to have a positive impact on the adoption of innovative policies (Ahn, 20 I I; Moon, 2002). For example, Manoharan (20 I 3) showed that when a U.S. county has a website for more years it has more advanced e-government practices than a county that has a website for a lesser number of years. Another important resource is political attention, which may result in the allocation of human and financial resources to a particular policy area (Jacoby \& Schneider, 200 I). For example, Homburg and Dijkshoorn (20 I I) hypothesized that governments with an ICT portfolio for a mayor or aldermen - who are the main governing body of a Dutch municipality - have more extensive personalized e-government services. However, they found no support for this hypothesis. 


\section{Social resources}

Not only resources that are internal to municipalities are important, also external resources must be considered because governments do not take policy adoption decisions in isolation. The research on innovations has historically been concerned with resources external to governments to explain why a certain policy has spread among governments (Berry \& Berry, I990; Walker, I969). In this dissertation the external resources pertain to the degree to which a municipality has access to relevant vertical and horizontal networks (Berry \& Berry, 2007). Walker ( 1969) was one of the first scholars interested in the geographic spread of adoptions of new programs. He was interested in the conditions under which state decisionmakers in the United States were most likely to adopt a new program. His main conclusion was that the likelihood for a state to adopt a new program was higher when other states had already adopted the new program. In later studies much support has been found for this claim that policies diffuse among neighboring governments, or governments that share certain characteristics. For example, Volden (2006) found support for the idea that similar states are more likely to emulate their geographic neighbors and those with similar political, demographic and budgetary characteristics. Shipan and Volden (2006) found that the adoption of laws in neighboring states increases the likelihood that a state will adopt a similar policy.

Horizontal or vertical policy networks, and professional networks are external social resources that have often been associated with differences in innovativeness among governments (McNeal et al., 2003; Sugiyama, 2008). These networks are considered important, because they are assumed to facilitate information sharing among policymakers and politicians. For example, Sugiyama (2008) shows that Brazilian cities that were linked to influential policy networks were more likely to adopt an innovative education program and an innovative family health program. Karch (2007a) showed that national intervention in the innovation process is important, especially in the early stages of political decision making, by providing relevant information. Also, Füglister (20 I b) found that institutionalized intergovernmental networks - for example through regional conferences - promote the diffusion of best practices in health policy innovation among Swiss cantons. Whether a policy just spreads because governments adopt a certain policy regardless of other governments' policy decisions - in the literature referred to as spurious diffusion (Braun \& Gilardi, 2006, p. 299) - or whether it spreads because an adoption decision of one government is influenced by other governments is the reason why the distinction between internal and external factors is relevant (Berry \& Berry, 2007). In this dissertation we aim to determine to what extent local governments are influenced by other local governments' decisions by empirically testing explanations about horizontal decision-making interdependencies between local governments. 


\subsection{Explaining innovativeness by combining motivations, obstacles, and resources}

In the preceding sections we have described the three attributes of innovation - motivations, obstacles, and resources - that we consider to be relevant in explaining differences in innovativeness among municipalities. According to the decentralization-thesis policy innovations after decentralizations should be mainly guided by the desire of local politicians and local policymakers to shape local policies to local needs and demands, and to differences in political priorities. When the decentralization-thesis is true this means that it are only motivational factors that are important in explaining differences in innovativeness. However, by taking into account the obstacles and resources from Mohr's (r969) model of innovation, we have also presented alternative explanations for innovation that nuance the expectation of the decentralization-thesis. Table 2 shows which factors of these three attributes of innovation are assumed to answer the second (explanatory) part of our four subquestions. In Table 2, for all four chapters in this dissertation the factors that we assume to explain innovation are presented. 'Yes' means that for that specific research case we have derived a hypothesis for that factor. 'No' means that we have not derived and not tested a

Table 2. Factors explaining innovation.

\begin{tabular}{|c|c|c|c|c|}
\hline & $\begin{array}{c}\text { E-government } \\
\text { (Chapter 2) }\end{array}$ & $\begin{array}{c}\text { Youth and Family } \\
\text { (Chapter 3) }\end{array}$ & $\begin{array}{c}\text { E-democracy } \\
\text { (Chapter 4) }\end{array}$ & $\begin{array}{l}\text { Prostitution } \\
\text { (Chapter5) }\end{array}$ \\
\hline \multicolumn{5}{|l|}{ Motivation } \\
\hline \multicolumn{5}{|l|}{ Policy-seeking } \\
\hline Problem severity/Needs & Yes & Yes & Yes & Yes $(2)$ \\
\hline Political/Citizen demands & No & No & Yes $(2)$ & Yes \\
\hline Ideology & Yes & Yes (2) & Yes (2) & Yes \\
\hline \multicolumn{5}{|l|}{ Vote-seeking } \\
\hline Electoral competition & No & Yes & Yes & No \\
\hline \multicolumn{5}{|l|}{ Obstacles } \\
\hline Party fragmentation & Yes & Yes & Yes & Yes \\
\hline Complexity & Yes & No & No & No \\
\hline \multicolumn{5}{|l|}{ Resources } \\
\hline \multicolumn{5}{|l|}{ Human/financial } \\
\hline Organizational capacity & Yes & Yes & Yes & Yes \\
\hline Past performance & Yes & No & Yes & No \\
\hline Information & Yes & No & No & No \\
\hline Political portfolio & No & Yes & Yes & No \\
\hline \multicolumn{5}{|l|}{ Social } \\
\hline Professional network & No & Yes & Yes & Yes \\
\hline Regional policy network & Yes & Yes & No & No \\
\hline
\end{tabular}

Note: Yes; A hypothesis for this factor is tested. No; No hypothesis for this factor is tested. In parentheses the number of hypotheses in cases we test multiple hypotheses for a factor. 
specific hypothesis for that innovation factor. In cases of multiple hypotheses for a factor, the number of hypotheses is shown between parentheses. In cases of a 'No', this can either be the result of a lack of available indicators (data), or it is the result of an indicator not being relevant for the specific policy that we studied. In Chapter 6 we will present a table - comparable to Table 2 in this chapter - that summarizes the results of our hypotheses tests.

As we explained, we expect all three factors - motivations, obstacles and resources - to be important determinants for differences in governments' levels of innovativeness (Berry \& Berry, 2007, 20I4). However, we expect motivations and resources to have different impacts on the extent of innovativeness depending on the type of policy that is being examined (compare, Gray, I 973). We only chose to make a distinction in the differential impact of motivations and resources depending on the type of policy under consideration, because we expect obstacles to be equally important for innovation in all chapters. We examine both voluntary and mandated innovations, and administrative and political innovations. For mandated policies we would expect that it are primarily resources that are important for innovation, because in the end, there is no other option for municipalities than to adopt the innovation. It has been found that resources, in form of prior experience with aspects of a program, strongly contributed to innovation adoption in a public management reform that involved an external authority decision (Boyne et al., 2005) - which we consider to be comparable with the mandated innovations in this dissertation. For the voluntary innovations in our dissertation we expect that primarily motivations are responsible for differences in innovativeness among governments.

The other distinction between policy types is that between administrative and political innovations. The expectation is that for administrative innovations, primarily resources can be considered relevant, and for political innovations it is expected that motivations are more important than are resources. Motivations are considered to be important for political innovations, because as we have explained before, these innovations are about normative choices between different conflicting values and consequences of these choices might as such have direct consequences for the citizens affected by these innovations. In contrast, for administrative innovations resources are considered more important, because these innovations are about reforming administrative practices and governmental processes, where the capability to innovate is considered more important. Boushey (20 r 0 ) found that resources were of less importance for the diffusion of political policies than they were for the diffusion of administrative policies, and Gray (1973) found that motivations were more important for the adoption of a political (social) policy than were resources. Also, others have shown that it were mainly motivational factors (social and political) that could explain State innovativeness in a political (welfare) policy (Soss et al., 200I). The four cases in this dissertation provide an ideal opportunity to investigate under what circumstances motivations are more important than resources for the realization of innovative policies in Dutch municipalities. For each policy type in this dissertation Table 3 shows our expectations for the influence of 
either motivations or resources, or for a combination of both. In Chapter 6 we will give an overview of the results that we found regarding the influence of motivations and resources on levels of municipalities' innovativeness.

Table 3. Expected importance for motivations and resources for each policy type.

\begin{tabular}{ccc}
\hline & Administrative & Political \\
\hline Mandated & Resources & Motivations + Resources \\
Voluntary & Motivations + Resources & Motivations \\
\hline
\end{tabular}

\section{Outline of this dissertation}

In this dissertation we investigate differences in innovativeness among Dutch municipalities for different types of policies. The policies we investigate are either administrative or political, and either voluntary or mandated. We have divided this dissertation in four substantive chapters that each present a separate research case. To answer questions about explanations for differences in innovativeness for the types of policies that we distinguish, we apply an in innovation studies commonly used framework, that combines the motivations, obstacles, and resources for innovation (Berry \& Berry, 2007; Mohr, I 969). In Chapter 2 we explain differences in the timing of the adoption of a mandated administrative (e-government) innovation, and in Chapter 3 we explain differences in the timing of the realization of a mandated political (social) policy. In Chapter 4 we explain differences in the extent of development for an administrative (e-democracy) innovation, and in Chapter 5 we explain differences in the extent of innovation in content for a political (moral) policy. The four empirical chapters (Chapters 2-5) are all written as individual journal articles. Consequently, this means that there are some repetitive elements among the four chapters, but it also means that the four empirical chapters are completely readable independently of each other. Finally, in Chapter 6, we present the answers to our sub-questions, and the answer to our main research question. We end with a conclusion and discussion of our main findings, and we provide suggestions for future research. 


\section{REFERENCES}

Adams, J., \& Somer-Topcu, Z. (2009). Policy adjustment by parties in response to rival parties' policy shifts: Spatial theory and the dynamics of party competition in twenty-five post-war democracies. British Journal of Political Science, 39(04), 825-846.

Ahn, M. J. (20 I I). Adoption of Applications in U.S. Municipalities: The Role of Political Environment, Bureaucratic Structure, and the Nature of Applications. The American Review of Public Administration, 4I (4), 428-452. doi: I O. I I $77 / 02750740$ I0377654

Allard, S. W. (2004). Competitive pressures and the emergence of mothers' aid programs in the United States. Policy Studies Journal, $32(4), 52$ I-544.

Allen, M. D. (2005). Laying Down the Law? Interest Group Influence on State Adoption of Animal Cruelty Felony Laws. Policy Studies Journal, 33(3), 443-457. doi: I 0. I I I I/j. I 54 I-0072.2005.00 I 24.X

Balla, S. J. (200 I). Interstate Professional Associations and the Diffusion of Policy Innovations. American Politics Research, 29(3), 22 I-245. doi: I0. I I 77/I 532673 X0 I 29300 I

Baturo, A., \& Gray, J. (2009). Flatliners: Ideology and rational learning in the adoption of the flat tax. European Journal of Political Research, 48( I), I 30-I 59. doi: I 0. I I I I/j. I 475-6765.2008.00830.x

Baybeck, B., Berry, W. D., \& Siegel, D. a. (20 I I). A Strategic Theory of Policy Diffusion via Intergovernmental Competition. The Journal of Politics, 73( ० I ), 232-247. doi: I 0.10 I 7/S०02238 I 6 I 0000988

Beetham, D. ( 1 996). Theorising democracy and local government. In D. King \& G. Stoker (Eds.), Rethinking local democracy (pp. 28-49). London: Macmillan.

Berry, F. S. ( I 994). Innovation in Public Management: The Adoption of Strategic Planning. Public Administration Review, 54(4), 322-330. doi: $10.2307 / 977379$

Berry, F. S., \& Berry, W. D. ( I 990). State lottery adoptions as policy innovations: An event history analysis. American Political Science Review, 84(2), 395-4 I 5 .

Berry, F. S., \& Berry, W. D. (2007). Innovation and diffusion models in policy research. In P. A. Sabatier (Ed.), Theories of the Policy Process (second., pp. 223-260). Boulder, CO: Westview Press.

Berry, F. S., \& Berry, W. D. (2o I 4). Innovation and diffusion models in policy research. In P. A. Sabatier \& C. M. Weible (Eds.), Theories of the Policy Process (Third., pp. 307-359). Boulder, CO: Westview Press.

Boehmke, F. J., \& Skinner, P. (20 I 2). State policy innovativeness revisited. State Politics \& Policy Quarterly, I 2(3), 303329.

Boehmke, F. J., \& Witmer, R. (2004). Disentangling diffusion: The effects of social learning and economic competition on State policy innovation and expansion. Political Research Quarterly, 57 (I), 39-5 I. doi: I O. I I 77/ I0659I 290405700 I 04

Bol, D., Pilet, J., \& Riera, P. (20 I 5). The international diffusion of electoral systems: The spread of mechanisms tempering proportional representation across Europe. European Journal of Political Research, 54(2), $384-4 \mathrm{I}$ o.

Boushey, G. (201 o). Policy diffusion dynamics in America. Cambridge University Press.

Boyne, G. A., Gould-Williams, J. S., Law, J., \& Walker, R. M. (2005). Explaining the adoption of innovation: An empirical analysis of public management reform. Environment and Planning C: Government \& Policy, 23(3), 4 I 9435 .

Braun, D., \& Gilardi, F. (2006). Taking “Galton”s Problem’ Seriously: Towards a Theory of Policy Diffusion. Journal of Theoretical Politics, I 8(3), 298-322. doi: I 0. I I 77/095 I 62980606435 I

Brooks, S. M. (2005). Interdependent and domestic foundations of policy change: The diffusion of pension privatization around the world. International Studies Quarterly, 49(2), 273-294.

Brooks, S. M. (2007). When does diffusion matter? Explaining the spread of structural pension reforms across nations. Journal of Politics, 69(3), 70 I-7 I 5 .

Budge, I., \& Laver, M. ( I 986). Office seeking and policy pursuit in coalition theory. Legislative Studies Quarterly, $4^{8} 5-$ 506 .

Calista, D. J., \& Melitski, J. (20 I 3). Digitized Government Among Countries Worldwide From 2003 to 20 I o: Performance Discrepancies Explained by Comparing Frameworks. International Journal of Public Administration, 36(3), 222-234. doi: 1 0.1 $1080 / 01900692.2012 .72$ I 246

Clark, J. ( I 985 ). Policy diffusion and program scope: Research directions. Publius, ${ }_{5}$ (4), 6 I-70. 
Dahl, P. S., \& Hansen, K. M. (2006). Diffusion of standards: The importance of size, region and external pressures in diffusion processes. Public Administration, 84(2), 44 I-459. doi: I o. I I I I/j. I 467-9299.2006.000 I I.x

Daley, D. M., \& Garand, J. C. (2005). Horizontal diffusion, vertical diffusion, and internal pressure in state environmental policymaking, I 989-1 998. American Politics Research, 33(5), 6 I 5-644. doi: I O. I I 77/I $532673 \times 042734$ I 6

De Vries, M. S. (2000). The rise and fall of decentralization: A comparative analysis of arguments and practices in European countries. European Journal of Political Research, 38(2), I 93-224. doi: I o. I I I I/ I 475-6765.00532

Denters, B. ( 198 I ). Kwantitatief-vergelijkende beleidsanalyse met betrekking tot subnationale overheden: een overzicht. Acta Politica, I 6( I), 27-65.

Denters, B. (2005). Towards local governance? In B. Denters \& L. E. Rose (Eds.), Comparing local governance: Trends and developments (pp. 246-262). New York, NY: Palgrave Macmillan.

Denters, B., \& Rose, L. E. (2005). Comparing local governance-trends and developments. New York.

Denters, B., Van Heffen, O., \& De Jong, H. M. ( I 999). Proeftuin of procrustesbed? Gemeentelijk jeugd- en veiligheidsbeleid in het kader van het grote-stedenbeleid, I 995-I 997. Bestuurskunde, 3, I ०6-I I 5.

DiMaggio, P. J., \& Powell, W. W. ( 1983 ). The Iron Cage Revisited: Institutional Isomorphism and Collective Rationality in Organizational Fields. American Sociological Review, 48(2), I 47-I60. doi: I 0.2307/2095 I I

DiMaggio, P. J., \& Powell, W. W. (r 99 I). The iron cage revisited: Institutional isomorphism and collective rationality in organizational fields. In W. W. Powell \& P. J. DiMaggio (Eds.), The new institutionalism in organizational analysis (pp. 63-82). The University of Chicago Press.

Easton, D. (1 953). The Political Systems: An Inquiry into the State of Political Science. New York: Knopf.

Elkins, Z., \& Simmons, B. A. (2005). On waves, clusters, and diffusion: A conceptual framework. Annals of the American Academy of Political and Social Science, 598, 33-5 I. doi: I 0. I I 77/00027 I 62042725 I 6

Fleurke, F., \& Hulst, R. (2006). A Contingency Approach to Decentralization. Public Organization Review, 6(r), $37-56$. doi: I ०. I $007 /$ S I I I I 5-006-6902-4

Fleurke, F., Hulst, R., \& Vries, P. de. ( I 997). Decentraliseren met beleid: een heuristiek. Den Haag: SDU.

Füglister, K. (20 I I a). Cantons as Policy Laboratories of the Federal State? The Diffusion of Health Insurance Subsidy Policies among the Swiss Cantons. (Doctoral Dissertation) University of Zürich.

Füglister, K. (20 I I b). Where does learning take place? The role of intergovernmental cooperation in policy diffusion. European Journal of Political Research, 5 I (3), 3 I 6-349. doi: I 0. I I I I/j. I 475-6765.20 I I .02000.x

García-Sánchez, I.-M., Rodríguez-Domínguez, L., \& Gallego-Álvarez, I. (20 I I). The Relationship between Political Factors and the Development of E-Participatory Government. The Information Society, 27(4), $233-25$ I.

Gerven, M. van, Vanhercke, B., \& Gürocak, S. (20 I 4). Policy learning, aid conditionality or domestic politics? The Europeanization of Dutch and Spanish activation policies through the European Social Fund. Journal of European Public Policy, 2 I (4), 509-527. doi: I 0. I 080/I 350 I 763.20 I 3.862 I 75

Gilardi, F. (2008). Delegation in the regulatory state: independent regulatory agencies in Western Europe. Cheltenham, United Kingdom: Edward Elgar Publishing.

Gilardi, F. (20 10). Who learns from what in policy diffusion processes? American Journal of Political Science, 54(3), 650-666. Retrieved from $<$ Go to ISI $>$ ://000279020 100005

Gilardi, F., \& Füglister, K. (2008). Empirical Modeling of Policy Diffusion in Federal States: The Dyadic Approach. Swiss Political Science Review, I 4(3), 4 I 3-450. doi: I 0. $1002 /$ j. I 662-6370.2008.tboo I ०8.x

Gilsing, R. (2005). Bestuur aan banden: lokaal jeugdbeeld in dwe greep van matinaal beleid. Sociaal en Cultureel Planbureau.

Gilsing, R. (2007). Intergovernmental relations and the effectiveness of local governance the case of Dutch youth policy. International Review of Administrative Sciences, 73(I), 45-64.

Glick, H. R., \& Hays, S. P. ( I 99 I). Innovation and reinvention in state policymaking: Theory and the evolution of living will laws. The Journal of Politics, $53(03), 835-850$.

Goldsmith, M. (2005). A new Intergovernmentalism? In B. Denters \& L. E. Rose (Eds.), Comparing local governance: Trends and developments (pp. 228-245). New York, NY: Palgrave Macmillan.

Goldsmith, M., \& Page, E. C. (2० I ०). Changing government relations in Europe: From localism to intergovernmentalism. London, England: Routledge. 
Goldthorpe, J. H. ( I 996). The quantitative analysis of large-scale data-sets and rational action theory: For a sociological alliance. European Sociological Review, I2(2), 1 $09-\mathrm{I} 26$.

Graham, E. R., Shipan, C. R., \& Volden, C. (2013). The Diffusion of Policy Diffusion Research in Political Science. British Journal of Political Science, 43(03), 673-70 I. doi: I 0. I । I 7/S०007 I 234 I 20004 I 5

Gray, V. (I 973). Innovation in the states: A diffusion study. The American Political Science Review, 67(4), I I 74-I I 85.

Gregg, P. M. ( ( 974). Units and levels of analysis: A problem policy analysis in federal systems. Publius, 59-86.

Haider-Markel, D. P., \& Meier, J. ( I 996). The Politics of Gay and Lesbian rights: Expanding the Scope of the Conflict. The Journal of Politics, $58(2), 332-349$.

Hall, P. G. (1998). Cities in civilization. Pantheon Books New York.

Hansen, M. B. (20 I I). Antecedents of organizational innovation: The diffusion of new public management into Danish local government. Public Administration, 89(2), 285-306. doi: I 0. I I I I/j. I 467-9299.20 I 0.0 I 855.x

Hays, S. P. ( 1 996). Influences on reinvention during the diffusion of innovations. Political Research Quarterly, 49(०3), 63 I -650 .

Hedström, P. (2005). Dissecting the social: On the principles of analytical sociology. Cambridge University Press Cambridge.

Henrich, J. (200 I). Cultural Transmission and the Diffusion of Innovations: Adoption Dynamics Indicate That Biased Cultural Transmission Is the Predominate Force in Behavioral Change. American Anthropologist, I 03(4), 992I 0 I 3. doi: I $0.2307 / 684$ I 25

Homburg, V., \& Dijkshoorn, A. (20 I I). Diffusion of personalized e-government services among Dutch municipalities: an empirical investigation and explanation. International Journal of Electronic Government Research, 7(3), 2 I-37.

Homburg, V., Dijkshoorn, A., \& Thaens, M. (20 I 3). Diffusion of Personalised Services among Dutch Municipalities: Evolving Channels of Persuasion. Local Government Studies, 40(3), I-22. doi: I 0. I 080/03003930.20 I 3.795892

Hwang, S.-D., \& Gray, V. ( I 99 I). External limits and internal determinants of state public policy. The Western Political Quarterly, 277-298.

J\&G. (2007). All opportunities for all children, youth and family program 2007-20 I I [In Dutch: Alle kansen voor alle kinderen, programma voor Jeugd en Gezin 2007-20 I I ]. The Hague, The Netherlands: Programmaministerie voor Jeugd en Gezin.

Jacoby, W. G., \& Schneider, S. K. (200 I). Variability in state policy priorities: An empirical analysis. Journal of Politics, $63(2), 544-568$.

Jensen, J. L. (2004). A Multipopulation Comparison of the Diffusion of Public Organizations and Policies across Space and Time. Policy Studies Journal, 32(I), I 09-I 27. doi: I O. I I I I/j. I 54 I-0072.2004.00055.x

Karch, A. (2006). National intervention and the diffusion of policy innovations. American Politics Research, 34(4), 403426. doi: I O. I I 77/ I 532673 X 06288202

Karch, A. (2007a). Democratic Laboratories. Policy diffusion among the American states. Ann Arbor: The University of Michigan Press.

Karch, A. (2007b). Emerging issues and future directions in state policy diffusion research. State Politics E Policy Quarterly, 7(I), 54-80. doi: I 0.I I 77/I 53244000700700104

Karch, A., \& Cravens, M. (2o I I). Policy Diffusion, Program Content, and Post-Adoption Reform: The Adoption and Modification of Three Strikes Laws. Annual conference on State politics and public policy. Hanover, NH.

Karch, A., \& Cravens, M. (20 I 4). Rapid Diffusion and Policy Reform: The Adoption and Modification of Three Strikes Laws . State Politics E Policy Quarterly, I 4 (4 ), 46 I-49 I. doi: I o. I I 77/ I 5324400 I 456 I 867

Kim, S., \& Lee, J. (20 I 2). E-Participation, Transparency, and Trust in Local Government. Public Administration Review, 72(6), 8 I 9-828. doi: I 0. I I I I j. I 540-62 I 0.20 I 2.02593.x

Kolsaker, A., \& Lee-Kelley, L. (2007). "Mind the Gap II": E-Government and E-Governance. In Electronic Government (pp. 35-43). Springer.

Korteland, E. (2० I ). Diffusie en adoptie van interorganisationele innovaties in de publieke sector: een onderzoek binnen de beleidssectoren onderwijs en veiligheid. (Doctoral Dissertation) Rotterdam: Erasmus University.

Krause, R. M. (20 I I). Policy Innovation, Intergovernmental Relations, and the Adoption of Climate Protection Initiatives By U.S. Cities. Journal of Urban Affairs, 33 ( I), 45-60. doi: I o. I I I I j j I 467-9906.20 I 0.005 I 0.x

Lasswell, H. D. ( 1 950). Politics: Who Gets What, When, How. New York, Whittlesey House. New York: Peter Smith. 
Lee, C., Chang, K., \& Berry, F. S. (20 I I). Testing the Development and Diffusion of E-Government and E-Democracy: A Global Perspective. Public Administration Review, 7 I (3), 444-454.

Lee, C. K., \& Strang, D. (2006). The international diffusion of public-sector downsizing: Network emulation and theorydriven learning. International Organization, 6o(4), 883-909. doi:Doi I o. I $~ 1$ 7 /S०0208 I 830606292

Levels, M., Sluiter, R., \& Need, A. (20 I 4). A review of abortion laws in Western-European countries. A cross-national comparison of legal developments between 1960 and 20 I 0 . Health Policy, I I 8( I), 95-1 44.

Maggetti, M., \& Gilardi, F. (20 I 4). Network governance and the domestic adoption of soft rules. Journal of European Public Policy, 2 I(9), I 293-I 3 I ०. doi: I 0. I $080 /$ I 350 I 763.20 I 4.9230 I 8

Mahajan, V., \& Peterson, R. A. (1 985). Models for innovation diffusion (Vol. 48). SAGE Publications, Incorporated.

Makse, T., \& Volden, C. (2० I I). The role of policy attributes in the diffusion of innovations. The Journal of Politics, 73(01), I08-I24. doi:10.1017/So022381610000903

Manoharan, A. (20I3). A Study of the Determinants of County E-Government in the United States. The American Review of Public Administration, 43(2), I 59-1 78.

McNeal, R. S., Tolbert, C. J., Mossberger, K., \& Dotterweich, L. J. (2003). Innovating in digital government in the American states. Social Science Quarterly, 84 ( I), 52-70.

Meier, K. J., \& Johnson, C. M. ( I 990). The politics of demon rum - Regulating alcohol and its deleterious consequences. American Politics Quarterley, I 8(4), 404-429.

Mintrom, M. ( 1 997). Policy entrepreneurs and the diffusion of innovation. American Journal of Political Science, 4I(3), $738-770$.

Mintrom, M., \& Norman, P. (2009). Policy entrepreneurship and policy change. Policy Studies Journal, 37(4), $649-667$.

Mohr, L. B. ( I 969). Determinants of innovation in organizations. The American Political Science Review, 63 ( I), I I II 26.

Moon, M. J. (2002). The evolution of e-government among municipalities: Rhetoric or reality? Public Administration Review, 62(4), 424-433.

Mooney, C. Z., \& Lee, M.-H. ( 1 995a). Legislating Morality in the American States - the Case of Pre-Roe Abortion Regulation Reform. American Journal of Political Science, 39(3), 599-627. Retrieved from $<$ Go to ISI $>$ ://AI $995 \mathrm{RM}_{5} 8400005$

Mooney, C. Z., \& Lee, M.-H. ( 995 b). Legislating Morality in the American States: The Case of Pre-Roe Abortion Regulation Reform. American Journal of Political Science, 39(3), 599-627.

Mooney, C. Z., \& Lee, M.-H. ( I 999). The Temporal Diffusion of Morality Policy: The Case of Death Penalty Legislation in the American States. Policy Studies Journal, 27(4), 766-780. doi: I o. I I I I/j. I 54 I $0072.1999 . t b 02002 . x$

Mooney, C. Z., \& Lee, M.-H. (2000). The Influence of Values on Consensus and Contentious Morality Policy: U.S. Death Penalty Reform, i 956-82. The Journal of Politics, 62(I), 223-239.

Musso, J., Weare, C., \& Hale, M. (2000). Designing web technologies for local governance reform: good management or good democracy? Political Communication, I7( I), I-I 9.

Nicholson-Crotty, S. (2009). The Politics of Diffusion: Public Policy in the American States. The Journal of Politics, 7 I(OI), I 92. doi: I O. I I 7/S०02238 I608090I 29

Nieuwenhuis, R. (20 I 4). Family policy outcomes: combining institutional and demographic explanations of women's employment and earnings inequality in OECD countries, 1975-2005. (Doctoral Dissertation) University of Twente.

Norris, D. F., \& Moon, M. J. (2005). Advancing e-government at the grassroots: tortoise or hare? Public Administration Review, 65(I), 64-75.

Pollitt, C. (2005). Decentralization. A central concept in contemporary public management. The Oxford Handbook of Public Management, 37 I-397.

Pollitt, C., \& Bouckaert, G. (2004). Public management reform: a comparative analysis (2nd ed.). New York, NY: Oxford University Press.

Polsby, N. W. (1985). Political innovation in America: The politics of policy initiation. Yale University Press.

Regeerakkoord VVD PvdA. Bruggen slaan (2012). Den Haag.

Robertson, D. B. ( I 976). A theory of party competition. London: John Wiley \& Sons.

Rodríguez Domínguez, L., García Sánchez, I. M., \& Gallego Álvarez, I. (2० I I). Determining factors of e-government development: a worldwide national approach. International Public Management Journal, I 4(2), 2 I 8-248. 
Rogers, E. M. (2003). Diffusion of innovations (5th ed.). New York: Free Press.

Sapat, A. (2004). Devolution and innovation: The adoption of state environmental policy innovations by administrative agencies. Public Administration Review, 64(2), I 4 I - I 5 I. doi: I o. I I I I/j. I $540-62$ I 0.2004.00356.x

Scharpf, F. W. ( I 997). Games real actors play: Actor-centered institutionalism in policy research (Vol. I 997). Westview Press Boulder, CO.

Scott, J. K. (2006). "E” the people: Do US municipal government web sites support public involvement? Public Administration Review, 66(3), 34 I-353.

Shipan, C. R., \& Volden, C. (2006). Bottom-up Federalism: The Diffusion of Antismoking Policies from U.S. Cities to States. American Journal of Political Science, $50(4), 825-843$.

Shipan, C. R., \& Volden, C. (2008). The mechanisms of policy diffusion. American Journal of Political Science, 52(4), $840-857$.

Simmons, B. A., Dobbin, F., \& Garrett, G. (2008). The global diffusion of markets and democracy. Cambridge University Press.

Simmons, B. A., \& Elkins, Z. (2004). The globalization of liberalization: Policy diffusion in the international political economy. American Political Science Review, 98 ( o I), I 7 I-I 89.

Sluiter, R. (2012). The diffusion of morality policies among Western European countries between I 960 and 2010 : A Comparison of temporal and spatial diffusion patterns of six morality and eleven non-morality policies. (Doctoral Dissertation) Radboud University Nijmegen.

Somer-Topcu, Z. (2009). Timely decisions: The effects of past national elections on party policy change. The Journal of Politics, 7 I (OI ) , 238-248.

Soss, J., Schram, S. F., Vartanian, T. P., \& O’Brien, E. (200 I). Setting the terms of relief: Explaining state policy choices in the devolution revolution. American Journal of Political Science, 45(2), 378-395. Retrieved from http://www.jstor.org/stable/2669347

Sugiyama, N. B. (2007). Ideology and Social Networks: The Politics of Social Policy Diffusion in Brazil. ProQuest.

Sugiyama, N. B. (2008). Theories of policy diffusion: Social sector reform in Brazil. Comparative Political Studies, 4 I (2), I 93-2 I 6. doi: I 0. I I 77/00 I04 I 40073009 I6

Sugiyama, N. B. (20 I I). The diffusion of Conditional Cash Transfer programs in the Americas. Global Social Policy, I I (2-3), 250-278. doi: I o. I I 77/ I 468 o 8 I I I 42 I 295

Sugiyama, N. B. (20 I 2). Bottom-up Policy Diffusion: National Emulation of a Conditional Cash Transfer Program in Brazil. Publius: The Journal of Federalism, 42(I ), 25-5 I. doi: I 0.1 $093 /$ publius/pjro 19

Taylor, J. K., Lewis, D. C., Jacobsmeier, M. L., \& DiSarro, B. (20 I 2). Content and Complexity in Policy Reinvention and Diffusion: Gay and Transgender-Inclusive Laws against Discrimination. State Politics E Policy Quarterly, I 2 ( I ), 75-98. doi: I 0. I I 77/I 5324400 I I 433589

Tolbert, C. J., \& McNeal, R. S. (2003). Unraveling the effects of the Internet on political participation? Political Research Quarterly, 56(2), I 75-I 85 .

Tolbert, C. J., Mossberger, K., \& McNeal, R. S. (2008). Institutions, policy innovation, and e-government in the American states. Public Administration Review, 68(3), 549-563.

Toonen, T. A. J. ( 1987 ). The Netherlands: A decentralized unitary state in a welfare society. In R. A. W. Rhodes \& V. Wright (Eds.), Tensions in the territorial politics of Western Europe (pp. I 8-1 29). London, England: Frank Cass.

Toshkov, D. (20 I 3). Policy-making beyond political ideology: The adoption of smoking bans in Europe. Public Administration, 9 I (2), 448-468. doi: I O. I I I I/j. I 467-9299.20 I 2.02075.x

Van der Graft, P., \& Svensson, J. (2006). Explaining eDemocracy development: A quantitative empirical study. Information Polity, I I (2), I 23 -I 34.

Van der Laan, F., Van Aart, H. A. P., Denters, B., Halbersma, H. S., Van Heffen, O., \& De Jong, H. M. ( 998 ). Wondermiddelen zijn niet voorhanden: grote-stedenbeleid I 995-I 997: gemeentelijke beleidsruimte en de benutting daarvan. Delft: Eburon.

Van der Steen, M., \& Van Twist, M. (20 I 4). Weerbaar of wendbaar zijn? Strategische opties in de voorbereiding op de drie decentralisaties. Beleid En Maatschappij, 4I, I.

Van der Veer, J. C. V. (20 I3). Weg uit het verleden: Een institutionele analyse van de gemeentelijke uitwerking van de Wet maatschappelijke ondersteuning (Wmo). (Doctoral Dissertation) VU University Amsterdam. 
Van der Veer, J. C. V., Schalk, J., \& Gilsing, R. (2० I I). Decentralisatie: maatwerk of uniformiteit? Het Wmo-beleid van Nederlandse gemeenten. Beleid En Maatschappij, 38(3), 265-282.

Van Eijck, S. (2006). Koersen op het kind. Sturingsadvies deel I. The Hague, The Netherlands: Projectbureau Operatie Jong.

Van Gerven, M., \& Beckers, M. (2009). Unemployment protection reform in Belgium, Finland, the Netherlands, and the UK: Policy learning through open coordination? In J. Zeitlin \& M. Heidenreich (Eds.), Changing European Employment and Welfare Regimes: The Influence of the Open Method of Coordination on National Reforms (pp. 6 I-83). Routledge, New York.

Van Helden, J. G., \& Jansen, P. E. (2003). New Public Management in Dutch Local Government. Local Government Studies, 29(2), 68-88. doi: I $0.1080 / 0300393030855937$ I

Van Loon, A., \& Toshkov, D. (2015). Adopting open source software in public administration: The importance of boundary spanners and political commitment. Government Information Quarterly, 32(2), $207-2$ I 5. doi:http://dx.doi.org/ı о. Iо 16/j.giq.2015.01.004

Volden, C. (2006). States as policy laboratories: Emulating success in the children's health insurance program. American Journal of Political Science, $50(2), 294-3$ I 2.

VROM. (2009). Legal arrangement Basic Registrations Addresses and Buildings [In Dutch: Regeling Basisregistraties Adressen en Gebouwen]. Minister van Volkshuisvesting, Ruimtelijke Ordening en Milieubeheer, 8 juni 2009 , nr. BJZ2009038757. Retrieved November 9, 20 I I , from http://wetten.overheid.nl/BWBRo02596 I

Walker, J. L. (1 969). Diffusion of innovations among American States. American Political Science Review, 63(3), 880899.

Walker, R. M. (2006). Innovation type and diffusion: An empirical analysis of local government. Public Administration, 84(2), 3 I I-335. doi: I 0. I I I I j. I 467-9299.2006.00004.x

Walker, R. M., Avellaneda, C. N., \& Berry, F. S. (20 I I). Exploring the diffusion of innovation among high and low innovative localities. Public Management Review, I3 (I), 95-1 25. doi: I 0. I ०80/ I 47 I 9037.20 I 0.5० I 6 I 6

Ware, A. ( 1 992). Activist-leader relations and the structure of political parties: "Exchange" models and vote-seeking behaviour in parties. British Journal of Political Science, 22 ( O I), 7 I-92.

Weare, C., Musso, J. a., \& Hale, M. L. ( I 999). Electronic Democracy and the Diffusion of Municipal Web Pages in California. Administration \& Society, 3 I (3), 3-27. doi: I O. I I 77/009539999400935475

Weyland, K. (2005). Theories of policy diffusion: Lessons from Latin American pension reform. World Politics, $57(2)$, 262-295.

Weyland, K. (2009). Bounded rationality and policy diffusion: social sector reform in Latin America. Princeton University Press.

Yun, H. J., \& Opheim, C. (20 I o). Building on Success: The Diffusion of e-Government in the American States. Electronic Journal of E-Government, 8 



\section{CHAPTER 2. MANDATORY INNOVATION IN A DECENTRALIZED SYSTEM: THE ADOPTION OF AN E-GOVERNMENT INNOVATION IN DUTCH MUNICIPALITIES'}

\section{ABSTRACT}

Local governments, especially in decentralized states, are increasingly performing tasks previously the responsibility of national government as well as new tasks mandated by the national government. This research studies the conditions affecting the adoption of a mandated e-government innovation -'Basic Registration Addresses and Buildings' (BAG), in Dutch municipalities $(N=429)$ between 2008 and 20 I I. In contradiction to what theory suggested, a great deal of variation in the timing of adoption of BAG was found. The results of Event History Analysis (EHA) show that early adoption of BAG was primarily the result of a municipality's command over resources. More resourceful municipalities, that is, with better past e-government performance, that are better informed, and included in more extensive policy networks were more likely to adopt this innovation relatively early. Of the motivational factors included in our study, the degree of political alignment between the municipal council and national government proved an important factor in the timing of a municipality's adoption of BAG. This is a surprising finding, since it is an uncontroversial and technical governance innovation. This research also shows that classical diffusion explanations play a role, even in the case of a mandated innovation for which the time frame, and thus the time to learn from other governments, was relatively short.

\section{Introduction}

Local government in a decentralized polity potentially provides an ideal test bed or laboratory (Füglister, 20 г га; Karch, 2007a; Volden, 2006) for innovations in governance. In the context of decentralization, municipalities may come up with different responses to more or less similar policy challenges. It is possible that, on the basis of a careful evaluation of various programs, 'best practice' may be identified and more widely adopted. However, the extent to which the adoption of innovations in local government follows an innovation pattern based on the search for best solutions remains to be seen. It has, for example, been observed that

\footnotetext{
${ }^{1}$ Jans, W., Denters, B., Need, A., \& van Gerven, M. (201 5). Mandatory innovation in a decentralised system: the adoption of an e-government innovation in Dutch municipalities. Acta Politica. Advance online publication.

doi: $10.1057 /$ ap.201 4.36 .
} 
often local governments' responses to new challenges are characterized by a considerable degree of uniformity (Sugiyama, 2008). In particular, in the case of national regulations demanding the implementation of certain policies by municipalities, high degrees of uniformity are to be expected. Against this background, this paper aims to deepen our understanding of the process of adoption of innovations in local government. In our research, we define innovations simply as a program that is new to the political actor adopting it (compare, Mohr, I 969). This means that an innovation can be new to one municipality and labeled an innovation there even though other municipalities may already have adopted that innovation (Gray, I 994).

Most research into the diffusion of policy innovations has examined voluntary adoptions. The cumulative number of innovations over time is normally characterized by an s-shaped learning curve (Rogers, 2003). Such a learning curve illustrates a pattern of adoption in which there are a few early adopters, followed by what has been called an early majority and a late majority. Finally, there are the laggards. Collectively, these groups form an s-shape. In this type of research, political actors are assumed to be autonomous: free to decide whether or not to implement any particular innovation. Here diffusion refers to both the population level phenomenon of cumulative individual level decisions, and to explanations for individual level decisions based on interdependency between different adopters.

It has been argued that when simply mandating local governments to adopt a certain policy innovation, national governments create a "highly uninteresting form of diffusion, as nearly all state discretion is eliminated by national-level fiat" (Berry \& Berry, 2007, p. 23 I). However, we cannot assume that municipalities act precisely as they are instructed to; generally they will have some discretion in performing their mandatory tasks (Goldsmith \& Page, 20I०; Goldsmith, 2005). National mandates requiring local action do not usually suggest that all local governments should react in the same way, nor that they should all react at the same time. This, for example, was observed in the United States where state governments chose different paths of action under a common federal mandate (Soss et al., 200 I). Even if there is no discretion regarding the substance of the innovation, which is the case in our study, there may be freedom in terms of the timing of the adoption. Given the increased tendency to decentralize policy responsibilities from national to local governments in the Netherlands and other decentralized European countries (Denters, 2005; Pollitt \& Bouckaert, 2004), investigating both vertical (top-down) influence and local autonomy is very important. We emphasize the importance of how innovations in local government are adopted, and to what extent the pattern of mandated innovations also follows the s-shaped learning curve.

We argue that it is an empirical question to what extent there are differences in the timing of policy adoptions after a national government mandate. We address this question in a study of the adoption of the Basic Registration Addresses and Buildings (in Dutch: Basisregistratie Adressen en Gebouwen (BAG)) in the Netherlands. We examine the timing of the 
adoption of BAG for all 429 Dutch municipalities, addressing two research questions: ( I) "To what extent do differences exist among Dutch municipalities in the timing of the adoption of BAG?" and (2)"How can we explain differences in the timing of the adoption of BAG among Dutch municipalities?".

The scientific progress we aim for is twofold. First, our questions supplement earlier questions asking why a certain policy is or is not adopted by a certain polity (for example, Berry \& Berry, I990; Gray, I 973; Volden, 2006; Walker, I 969). Due to the mandated nature of the innovation of $\mathrm{BAG}$, the main question is no longer whether a municipality will adopt the innovation, but rather when. By focusing on the adoption of BAG as a mandated innovation, we are able to retest theoretical explanations that were originally designed to explain voluntary processes of policy adoption. From existing theories about uncoordinated innovations, we derive and test predictions for mandated innovations.

Second, local governments are often considered to be seedbeds for public sector innovations (Beetham, I 996; Denters \& Mossberger, 2006). In many instances municipalities have taken up new challenges, and experimented with innovative policies, modes of governance or institutional arrangements. Little is known, however, about whether and how municipalities adopt mandated innovations. So far diffusion research at the local level has mainly concentrated on voluntary adoption of innovations (for example, Hansen, 20 I I; Krause, 20 I ; Sugiyama, 2008; Walker, Avellaneda, \& Berry, 20 I I). A considerable amount of research focusing on e-government (related) innovations has also been carried out at the local level (for example, Ahn, 20 I I ; Homburg, Dijkshoorn, \& Thaens, 20 I 3 ; Moon, 2002; Norris \& Moon, 2005; Weare, Musso, \& Hale, I 999). In this paper we aim to contribute to a better understanding of innovation in local government in a decentralized system by examining patterns of adoption of a mandated e-government innovation in Dutch municipalities.

\section{Differences in timing of adoption among Dutch municipalities}

In this section we answer our first question on variation in the timing of the adoption of BAG among municipalities. In 2006 in the Netherlands, the national government, the provinces, the municipalities and the water boards agreed to improve public services by setting a goal to improve electronic government (Kamerstukken II 2005-2006). Since 2006, Dutch egovernment has concentrated on the establishment of thirteen so-called basic registrations that involve the storage and supply of important information about people, businesses and buildings (Kamerstukken II, 2005-2006). The main purpose of this nationwide system of basic registrations, of which BAG is one, is collecting and sharing relevant unambiguous data held in one central database. Data are collected and kept up-to-date, to provide accurate information to all administrative bodies and public services in the Netherlands. For example, since February 2012 ambulances have navigated using data provided by the BAG (Eoverheid.nl, 20 I 2 ). 
Responsibility for the law, the realization, and the financing of the nationwide BAG facility (In Dutch: Landelijke Voorziening BAG (LV BAG)) lay with the Ministry of Housing, Spatial Planning and the Environment (in Dutch: Ministerie van Volkshuisvesting, Ruimtelijke Ordening en Milieubeheer - hereafter referred to as VROM); VROM was also responsible for the overhead costs, such as support for municipalities, and the costs for the connecting audits. Municipalities were (financially) responsible for their local database containing address and building information from within their own territorial borders. If local systems complied with the national standards they were connected to the nationwide BAG facility managed by the Land Registry. In 2008, the Dutch States-General mandated that from July ist 2009 all municipalities were required to be connected to the nationwide BAG facility (VROM, 2009).

Figures I to 4 show, at four different moments in time, the municipalities that had not yet adopted BAG (in white), and the municipalities that had adopted BAG (in grey). VROM initially set July I ${ }^{\text {st }} 2009$ as the deadline for all municipalities. Figure I shows that only 4 out of 429 municipalities ( $1 \%$ ) had adopted BAG before the first deadline. VROM then, in consultation with the Association of Dutch Municipalities (in Dutch: Vereniging van Nederlandse Gemeenten - hereafter referred to as VNG), set January I ${ }^{\text {st }} 20$ I I as a new deadline. Figures 2 to 4 show developments after the first deadline. Figure 2 shows that $6_{3}$ municipalities ( $15 \%$ ) had adopted BAG by July I ${ }^{\text {st }} 20 \mathrm{I} \circ$, a year after the first deadline. Figure 3 shows that on December I $^{\text {st }} 20 \mathrm{II}$, a month before the second deadline, 248 municipalities (58\%) had adopted BAG. Figure 4 shows 4 I 5 municipalities (97\%) had adopted BAG by the second deadline. On April 8th 20 I I, the final municipality adopted BAG.

Figure 5 describes the pattern of innovation by representing the cumulative distribution of BAG-adoptions (the solid line) between August 2008 and May 20 I I. The first deadline (month I 7), and the second deadline (month 35 ) are represented by two vertical dotted lines. The cumulative distribution of BAG-adoptions (solid line) shows that it took over i 8 months for the adoption rate to increase. The increase in BAG-adoptions was strongest between 32 months and 34 months. This increase was probably due to the strongly upheld second deadline set by VROM and VNG. ${ }^{\mathrm{I}}$ Towards the end of the time period the line flattens, which means the rate of adoption decreased after the second deadline expired. By that time all Dutch municipalities had adopted BAG. Appendix I shows the major events and timelines of the adoption process.

In summary, Figures I to 5 show clear differences among municipalities. From these figures we conclude two things. First, there is considerable variation in the timing of the adoption of BAG. This implies that the adoption of a mandated innovation is by no means a mechanical process of central orders and local obedience. Local governments' discretion is clearly not eliminated by a national government mandate. The marked differences in timing demonstrate that the study of mandatory innovations is substantially more interesting than 
Berry and Berry (2007) suggested. Second, Figure 5 somewhat resembles an s-curve, which is often found for voluntary governance innovations. We will therefore examine to what extent theories that were developed for voluntary governance innovations can help to understand the processes of mandated innovations.

\section{Theory and hypotheses}

To explain variation among municipalities in the timing of BAG-adoptions, we derive predictions from basic assumptions underlying rational choice theory. These assumptions concern utility maximization, existing preferences, and decision-making under conditions of uncertainty. When local governments face problems, they tend to confront these problems in a more or less rational manner, by looking around for various possible solutions. By assuming that municipalities make rational choices in response to a mandate, we do not assume that all municipalities "act in an entirely rational manner: only that the tendency to act rationally, in the circumstances that prevail, is the common factor at work" (Goldthorpe, I 996, p. I I 5). Municipalities, based on the information available, and after - to some extent weighing the costs and benefits, select their preferred solution from a wide range of alternatives. Of course, in our case municipalities cannot choose the innovation to adopt, but they can choose when to adopt it. To explain differences in timing, we use an assumption postulated by Mohr ( I 969, p. I I 4) (see also, Berry \& Berry, I 990, 2007): "Innovation is directly related to the motivation to innovate, inversely related to the strength of obstacles against innovation, and directly related to the resources for overcoming such obstacles." In our case this means that when the willingness to innovate is high, obstacles that can delay innovation are small, and resources to overcome obstacles are large, the probability of municipalities adopting BAG will generally be high. ${ }^{2}$

In explaining the timing of the adoption of BAG, we look for factors reflecting municipalities' motivations, obstacles, and resources. In further developing our theoretical argument we refer to factors that are internal and external to municipalities. Simultaneously considering internal and external factors originates from Berry and Berry ( I 990), and has been widely, and convincingly, applied (Boehmke \& Witmer, 2004; Walker, 2006). In the context of mandated innovations the relevance of external intergovernmental factors in addition to internal local factors is even more pertinent, as national governments might provide facilities to create favorable conditions for successful implementation. We therefore accommodate both internal and external factors under Mohr's denominators, which we discuss below. ${ }^{3}$ 


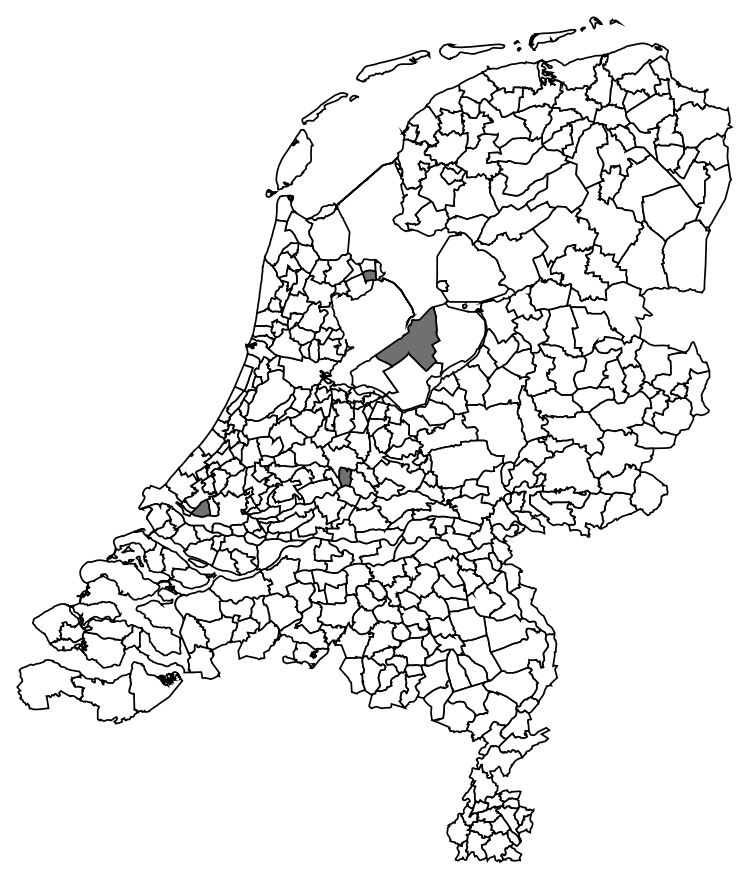

Figure 1. July $1^{\text {st }}$ 2009; First BAG deadline.

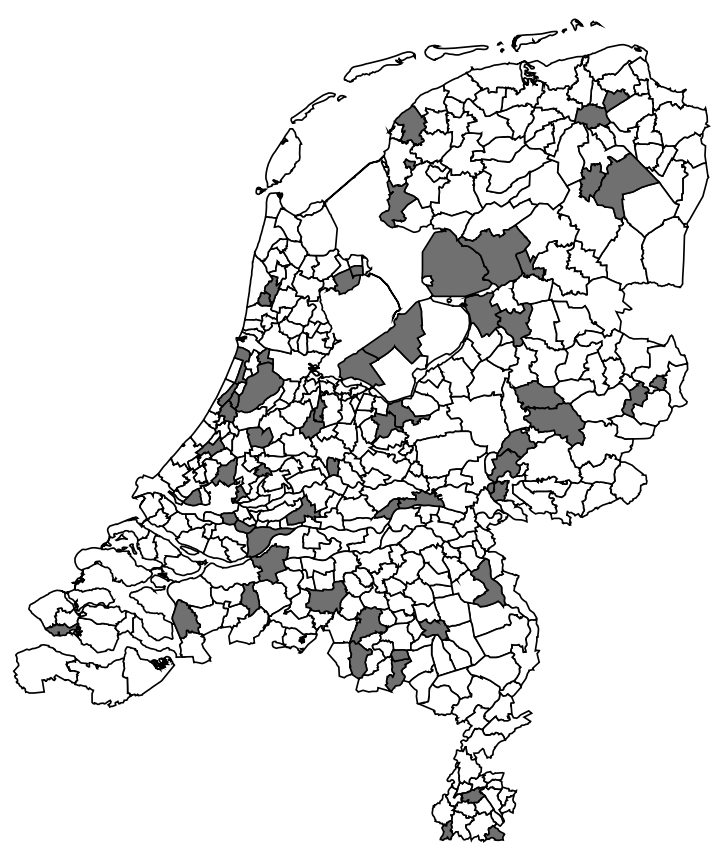

Figure 2. July $1^{\text {st }}$ 2010; A year after the $1^{\text {st }}$ BAG deadline. 


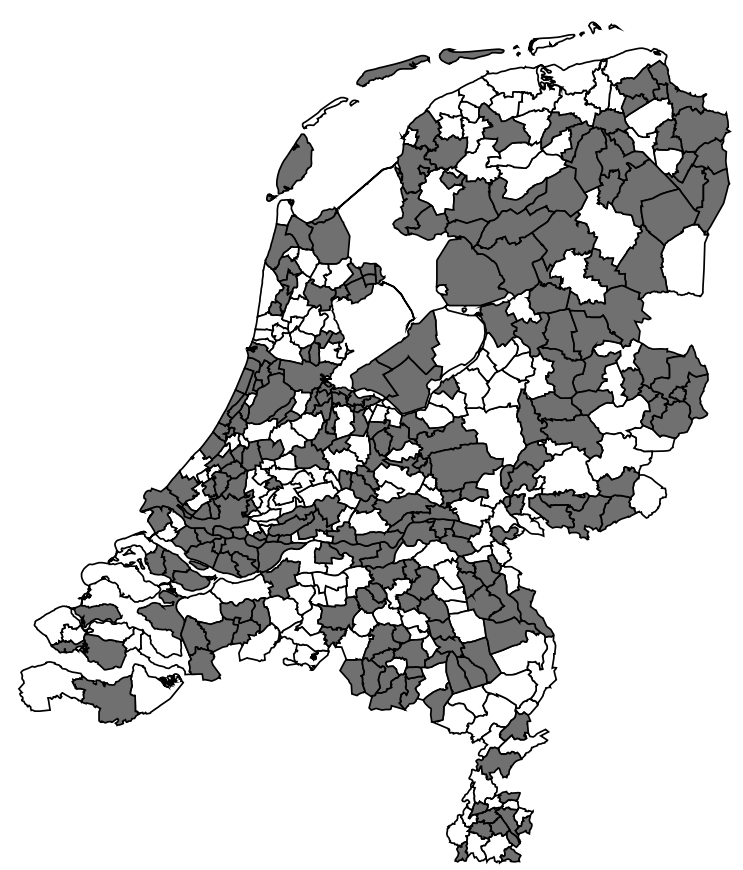

Figure 3. December $1^{\text {st }}$ 2010; A month before the second BAG deadline.

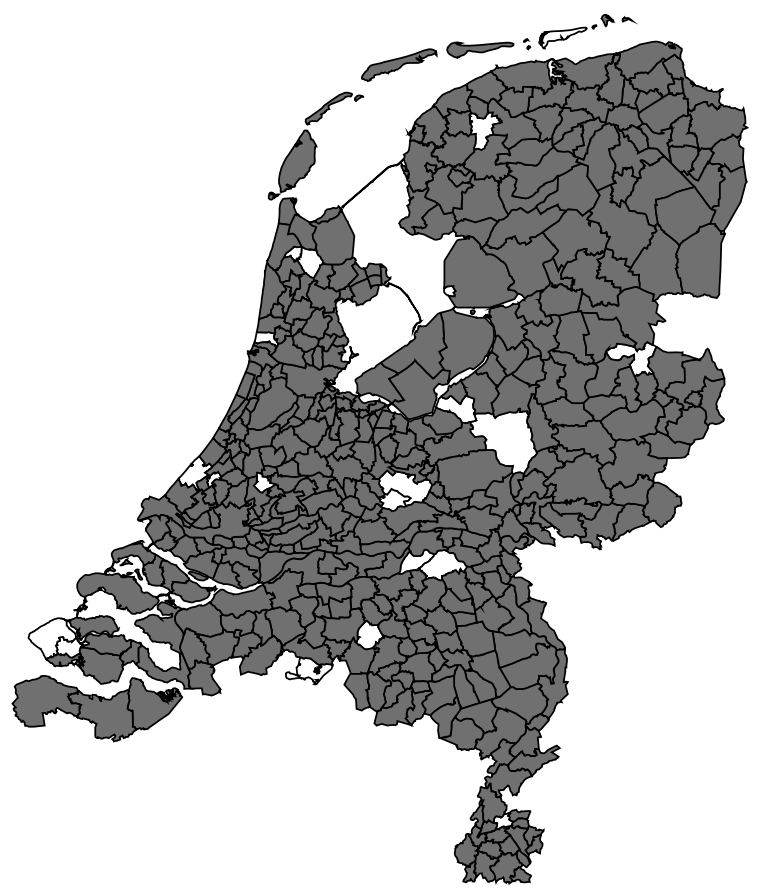

Figure 4. January $1^{\text {st }}$ 2011; Second BAG deadline.

Source Figures 1-4: @ 2011, Statistics Netherlands/ Land Registry Office, Zwolle, 2011; own calculations. 


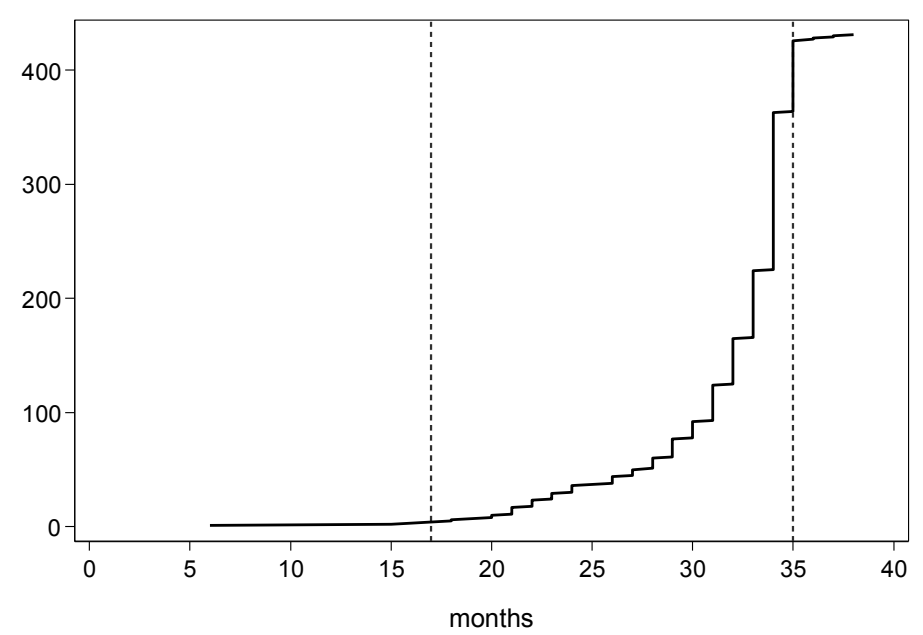

Figure 5. The cumulative distribution of BAG-adoptions for 429 municipalities in the Netherlands between the introduction of BAG legislation in 2008, and the last adoption in 2011.

\subsection{Motivation}

Motivation to innovate in government may stem from various sources. Governments are expected to provide adequate solutions for local problems, and they may want to act to meet these expectations. However, there is often ideological disagreement on the definition of such local problems, which may lower the motivation to innovate (Daley \& Garand, 2005; Makse \& Volden, 20 I I ; Traut \& Emmert, 2003). We assume more highly motivated municipalities will introduce an innovation sooner than less motivated municipalities. Hereby, we come to our most general hypothesis about municipalities' motivation. General Motivation Hypothesis: Municipalities that are more motivated to adopt BAG will do this sooner than municipalities that are less motivated to adopt BAG. We derive two specific hypotheses from this general motivation hypothesis.

Problem severity is the first motivational factor that has been hypothesized to be one of the possible reasons for political decision makers adopting a certain policy or not (Daley \& Garand, 2005; Karch, 2006; Sapat, 2004). Problem Severity Motivation Hypothesis: Municipalities are more likely to adopt BAG earlier if they perceive their recent address registration system as already being high quality.

The second factor we assume to be an indicator of the motivation to innovate relates to the highly interdependent character of the Dutch governmental system. It has been hypothesized that the composition of government may influence policy innovation (Berry \& Berry, I 990; Boehmke \& Witmer, 2004). Bearing in mind the local level discretion mentioned earlier, it might be expected that the degree of local level obedience to a central mandate will 
reflect central-local political differences. Political Alignment Motivation Hypothesis: Municipalities are more likely to adopt BAG earlier if their party preferences are more aligned to those of the national government.

\subsection{Obstacles}

In addition to motivation, obstacles may also affect the timing of adoption. Our most general hypothesis regarding the influence of obstacles is that municipalities experiencing fewer obstacles will implement innovations sooner than municipalities experiencing more obstacles. General Obstacles Hypothesis: Municipalities that have more obstacles will adopt BAG later than municipalities that have fewer obstacles. We derive two specific predictions from this general hypothesis.

First, the political fragmentation of a municipality is assumed to reduce the adoption speed. As other have hypothesized, it is difficult to take decisions in a politically fragmented setting, even if the issue itself is not politically highly charged (McNeal, Tolbert, Mossberger, \& Dotterweich, 2003). Numerous scholars have emphasized the importance of party fragmentation; for example, Brooks (2005) posits that party fragmentation is inversely related to the likelihood of successful innovation, and others have hypothesized that the probability of a state adopting a law is greater when a single party controls the governorship and both houses of the legislature, than when the state government is under divided control (Berry \& Berry, I 990; Boehmke \& Witmer, 2004). Political Fragmentation Obstacles Hypothesis: Municipalities are more likely to adopt BAG earlier if their level of party fragmentation is lower.

The relationship between the complexity of the innovation and the rate of adoption has also been hypothesized (Fliegel \& Kivlin, I 966; Rogers, 2003). In this context the complexity of the innovation is likely to increase with the number of buildings and addresses in a municipality. Each municipality is responsible for adding information about all buildings and addresses within its own boundaries; this is a very time-consuming job. Buildings Obstacles Hypothesis: Municipalities are more likely to adopt BAG later if they have more buildings.

\subsection{Resources}

The timing of adoption might also be affected by municipalities' command over financial, human and social resources. Financial resources refer to the amount of revenue, human resources refer to the quantity and quality of the municipal administrative staff, and social resources pertain to the degree to which a municipality has access to relevant vertical and horizontal networks. Our most general hypothesis regarding the influence of resources is 
that municipalities with more resources will implement innovations sooner than municipalities with fewer resources. General Resources Hypothesis: Municipalities with more resources will adopt BAG sooner than municipalities with fewer resources. We derive four specific hypotheses from this general hypothesis.

The first municipal resource is organizational size (Ahn, 20 I i; Walker, I 969; Weare et al., I 999). Larger organizations are generally more inclined to adopt innovations than smaller organizations, because they have greater financial resources and more human resources. Size Resource Hypothesis: Municipalities are more likely to adopt BAG earlier if they have more personnel and greater financial resources.

More specifically, we expect that technical capacity may be an important form of human resource in the development of e-government (Ahn, 20I I; Moon, 2002). The technical expertise available in a municipality will, to a large extent, determine a municipality's ability to implement new forms of e-government. We assume that the better the prior performance of a municipality within the e-government domain, the more likely it is to be an early adopter of any new e-government innovation. Past Performance Resource Hypothesis: Municipalities are more likely to adopt BAG earlier if their past performance in e-government is better.

The third resource relates directly to the multi-level government setting in which innovations are implemented. Karch (2007a, p. I43) found that national forces are very important in the information distribution process, particularly in the early stages of political decision-making. We assume that municipalities adopt earlier if they have access to information provided by VROM. Information Resource Hypothesis: Municipalities are more likely to adopt BAG earlier if they have more access to information.

Finally, there may be relevant horizontal inter-municipal-networks that can be considered as a resource. Walker ( 1969 ) was one of the first scholars to investigate the geographic spread and temporal patterns of newly adopted programs, concluding that states adopted new programs more often when other similar states had already adopted them. This tendency to adopt innovations in similar sub-national governments refers to a process of learning: if a policy was successful in a similar setting it might work 'with us'. Much support has been found for the claim that policies diffuse across neighboring polities (for example, Berry \& Berry, I 990; Volden, 2006). A well-known problem for geographic proximity as a driver for the spread of a policy is the difficulty in determining exactly why proximity should lead a policy to diffuse (Beck, Gleditsch, \& Beardsley, 2006; Karch, 2007b). In trying to achieve real understanding of where inter-governmental learning takes place, it is important to take into account the places where policy-makers exchange or acquire their information (Füglister, 20 I Ib). In line with other scholars, we therefore address intergovernmental organizations as a driver of policy diffusion (Füglister, 20 г гb; Sugiyama, 2008). Policy Network Resource Hypothesis: Municipalities are more likely to adopt BAG earlier if there are more municipalities in the same policy network that already have adopted BAG. 


\section{Method and data}

To test our hypotheses, we apply an event history analysis (EHA) which estimates the probability that a municipality with certain characteristics that has not yet adopted BAG, will adopt BAG at a particular point in time (see also, Berry \& Berry, r 990; Singer \& Willett, 2003). To do so, we constructed a municipality-month dataset that contains a record for each municipality in each month between the adoption of the BAG law in January 2008 and the moment of BAG adoption. Once a municipality adopts BAG, it is no longer 'at risk' of adopting, and it is excluded from our dataset for the following month. This means the number of observations for each municipality varies. For example, Vlaardingen, the first municipality to adopt BAG, is only 'at risk' for 5 months, whereas Apeldoorn, the last municipality to adopt, is 'at risk' for 37 months. In each month we examine each municipality, for a total of I 3,644 observations (429 municipalities $\times$ number of months from law up until the adoption). ${ }^{4}$ Appendix II presents the frequency distribution by month of adoption for the municipalities in our analysis.

Our research questions are about the timing of the adoption of BAG. We have therefore gathered information on the exact dates of BAG-adoptions by municipalities (VROM, 20 I I). This allows us to follow all municipalities through time starting from the adoption of the law in January 2008 until the final BAG adoption in April 20 I I. The units of analysis are therefore municipalities (referred to with subscript $i$ ) in certain months (referred to with subscript $t$ ). Our dependent variable, $A D O P T I O N_{i t}$, is a binary variable referring to whether or not municipalities adopted BAG in a certain month. Each month, the municipalities are assigned a score of $\mathrm{I}$ if they adopted BAG in that month, and a score of $\circ$ in all other months.

\subsection{Motivational variables}

The variable PROBLEM SEVERITY is measured by the question of how highly the responsible officials would rate the current standard of address registration (measured at the beginning of 2006) in their own municipality (scale ranges from $\circ$ (lowest) to 9 (highest)). Data are time-invariant and come from the report entitled 'Baseline measurement BAG', written by BMC Consultancy and Management (2006) at the request of VROM. ${ }^{5}$

We measure POLITICAL ALIGNMENT between municipal government and national government by the proportion of political parties in a municipal council that are represented in the national government's coalition. This variable ranges between $\odot \%$ and $87 \%$. The higher the percentage, the greater the local-national party alignment is. Data are time varying and were measured using data from local and national elections in 2006 and 20 I.${ }^{6}$ Data were obtained from Kiesraad (20 I I). 


\subsection{Obstacles variables}

PARTY FRAGMENTATION is measured by the Laakso-Taagepera index ( I 979), which reflects the effective number of political parties in a municipal council, by taking into account their relative size. The higher the score, the more fragmented a municipal council is. This variable ranges between I.53 and I 0.07. Data are time varying because local elections were held in 2006 and $2010 .^{7}$ They were obtained from Kiesraad (20 I I).

The number of BUILDINGS in a municipality is measured (at the end of $20 \mathrm{I}$ I) as the absolute number of buildings imported into BAG by each municipality. Data are timeinvariant and come from VROM. ${ }^{8}$

\subsection{Resources variables}

PAST PERFORMANCE with e-government is measured by making use of the EGovernment Ranking (in Dutch: Overheid.nl Monitor) (ICTU 2007-20 I ०). ${ }^{9}$ For each year during the period between I 999 and 20 I I, this monitor gives a relative score and compares the websites of all municipalities in the Netherlands, looking at their ability to provide various e-government services and e-government content to citizens. The measurements used to calculate the scores changed every year due to new priorities and new forms of egovernment. Measurements took place in the final three months of each year. Because we want to measure a municipality's prior experience with e-government, we use the scores from the previous year. For each year, a relative interval score, lying between 0 and 9I.4 was calculated.

Access to INFORMATION is measured (at the beginning of 2006) in two ways. The first one is familiarity with the BAG website ( $\mathrm{I}=\mathrm{yes}, \mathrm{o}=\mathrm{no}$ ) administered by VROM. The second one is subscription to the BAG newsletter ( $\mathrm{I}=\mathrm{yes}$, $\mathrm{o}=\mathrm{no}$ ) provided by VROM. We summed up the answers to both of these questions into one interval score ( $\mathrm{o}=$ none, $\mathrm{I}=$ one of the two, 2=both). Data are not time varying and are also taken from the report entitled 'Baseline measurement BAG' (BMC Consultancy and Management, 2006). ${ }^{\text {Io }}$

SIZE is a somewhat problematic measurement because larger populations self-evidently require larger organizations for service delivery (Walker et al., 20 I I ). We therefore included z-scores of the fulltime-equivalent (FTE) employees per I 000 inhabitants (BZK, 2008b) (data comes from the Ministry of the Interior and Kingdom Relations; in Dutch: Ministerie van Binnenlandse Zaken (BZK)), the amount of money municipalities received from the municipal fund (BZK, 2008a), and the population size (Statistics Netherlands, 20 I I) into one reliable scale for the years 2008 to $20 \mathrm{I} \mathrm{I.}^{\text {II }}$

VROM divided municipalities into regional contact groups which, between 2006 and 2009 and approximately every six to eight weeks, worked towards connecting to the nationwide BAG-database, under the guidance of an assigned BAG-account manager and BAG- 
expert. The four major municipalities Amsterdam, Rotterdam, The Hague and Utrecht had their own contact group. There were also pilot project participants, who jointly formed a separate contact group. ${ }^{12}$ To measure whether or not it matters if municipalities in the same policy network (ADOPTION ${ }_{j t}$ POLICY NETWORK) have already adopted BAG, a variable was constructed which measures the cumulative number of municipalities in the same policy network that had previously adopted BAG. Data are time-variant and come from VROM.

Each municipality contributes multiple records (one for each month under study) to our data set. Since these repeated measures may contain temporal dependence, we account for that by including $\mathrm{t}, \mathrm{t}^{2}$ and $\mathrm{t}^{3}$ (Carter \& Signorino, 20 $\mathrm{r}$ ). ${ }^{\mathrm{I} 3}$ However, we have found multicollinearity to be a problem, and therefore demeaned $\mathrm{t}$, and used $\mathrm{t} / \mathrm{s} \circ \mathrm{o}$, and its square and cube. Table I presents the means, standard deviations, and range of all variables used in our analysis.

Table 1. Descriptive Statistics $(\mathrm{N}=429)$

\begin{tabular}{|c|c|c|c|c|c|}
\hline Information for: & Time Varying & Mean & sd. & Min. & Max. \\
\hline \multicolumn{6}{|l|}{ Dependent Variable } \\
\hline ADOPTION $_{\text {it }}$ & Yes & 0.03 & 0.17 & 0.00 & $\mathrm{I} .00$ \\
\hline \multicolumn{6}{|l|}{ Motivation } \\
\hline POLITICAL ALIGNMENT & Yes & 43.56 & I 4.12 & 0.00 & 86.67 \\
\hline PROBLEM SEVERITY & No & 6.15 & I.06 & 0.00 & 9.00 \\
\hline \multicolumn{6}{|l|}{ Obstacles } \\
\hline POLITICAL FRAGMENTATION & Yes & 4.83 & I. 28 & I. 53 & 10.07 \\
\hline BUILDINGS & No & 9.79 & 0.75 & 7.15 & I 3.79 \\
\hline \multicolumn{6}{|l|}{ Resources } \\
\hline SIZE & Yes & 0.00 & I.०० & -4.22 & 5.05 \\
\hline PAST PERFORMANCE & Yes & 38.14 & г г. 88 & 10.70 & 91.40 \\
\hline INFORMATION & No & I. 34 & 0.68 & 0.00 & 2.00 \\
\hline ADOPTION $_{\text {it }}$ POLICY NETWORK & Yes & I. 53 & 3.45 & 0.00 & 28.00 \\
\hline \multicolumn{6}{|l|}{ Duration } \\
\hline MONTHS & Yes & I 6.66 & 9.52 & 1.00 & 38.00 \\
\hline
\end{tabular}

\section{Findings}

As described above, our dependent variable is a dummy indicating whether or not a municipality $_{i}$ adopts BAG in a particular month. To test our hypotheses, and due to the dichotomous nature of our dependent variable, we employ logistic regression analysis. ${ }^{\mathrm{I}}$ The model parameters are estimated using Stata/IC I 2. I. In Table 2 we present the estimation coefficients, robust standard errors, and the AIC-value as measurement for the model fit. In model I all motivational factors are included, in model 2 only obstacles are included, and model 3 tests only for the influence of resources. Finally, model 4 shows the coefficients for motivation, obstacles, and resources side by side, along with the point estimate of the per- 
centage change in the odds ratio that accompanies a one-unit change in each independent variable.

Model I in Table 2 shows the results of the variables capturing municipalities' motivation to innovate. We expected that municipalities that were more highly motivated would have a larger likelihood of BAG-adoption. Of the motivational factors, only the coefficient of the political alignment variable shows up as positive and statistically different from zero. Its positive sign indicates that, in each month, municipalities that are politically more aligned with national government have a greater likelihood of adopting BAG. Holding all other variables constant at their mean, a one-point increase in political alignment is associated with

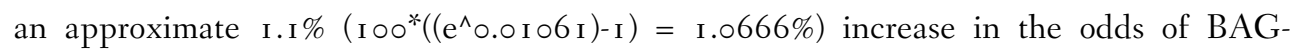
adoption. Given that this independent variable is measured on a scale between zero and 86.67 , it is difficult to give substantial meaning to a one-unit change. Interpretation of a one standard deviation increase, which is associated with an approximate $15 \%$ ( I ०*( I 4. I I $85^{*}$ ०.० I०6 I )) increase in the odds of BAG-adoption, may be more informative. The coefficient of problem severity does not attain conventional levels of statistical significance, and appears to be unrelated to the adoption of BAG. The implication of our findings in model $\mathrm{I}$ is that our motivational hypothesis, stating that more highly motivated municipalities adopt BAG sooner is only partly confirmed.

Model 2 in Table 2 shows the results for the variables reflecting obstacles to the adoption of BAG. We assumed that municipalities with fewer obstacles would adopt BAG earlier. On the basis of the political fragmentation coefficient, and the buildings-coefficient, which do not appear to be statistically different from zero, we conclude that our obstacles hypothesis cannot be confirmed.

The coefficients for the factors reflecting resources for BAG-adoption are shown in model 3, Table 2. We hypothesized that more resourceful municipalities would adopt BAG earlier. Three of the four resource specific factors included in the model have a positive and significant impact on the likelihood that a municipality will adopt BAG. The past performance variable shows that in each month municipalities that previously performed better with different forms of e-government have a greater likelihood of adopting BAG. When holding all other variables constant at their mean values, a one-unit increase in past performance is associated with a r.6\% change in odds, and a one standard deviation increase is associated with an approximate $19 \%$ increase in the odds of BAG-adoption. The positive coefficient of the information variable indicates that, in every month, municipalities that are better informed are more likely to adopt BAG. When holding other independent variables fixed at their central values, an additional unit yields an approximate i $9 \%$ higher odds ratio. We are cautious about placing too much confidence in this result, because of the possible imprecision of this particular time-invariant variable. The coefficient of the policy network 
Table 2. Logistic Regression Coefficients Explaining the Timing of the Adoption of BAG ( $\mathrm{N}$ observations $=13,644, \mathrm{~N}$ events $=429$ )

\begin{tabular}{llllll}
\hline & Model I & Model 2 & Model $_{3}$ & Model 4 & $\%$ Change \\
& $\beta(\sigma)$ & $\beta(\sigma)$ & $\beta(\sigma)$ & $\beta(\sigma)$ & in odds \\
\hline Motivation
\end{tabular}

Motivation

POLITICAL ALIGNMENT

$$
\begin{gathered}
0.0 \mathrm{II}^{* *} \\
(0.004)
\end{gathered}
$$

PROBLEM SEVERITY"

$$
\begin{gathered}
0.034 \\
(0.047)
\end{gathered}
$$

Obstacles

POLITICAL FRAGMENTATION
BUILDINGS $^{\#}$

Resources

PAST PERFORMANCE

\section{INFORMATION $^{\#}$}

SIZE

\section{ADOPTION $_{\mathrm{jt}}$ POLICY NETWORK}

\section{Duration}

time/ I ०

time/ 1 $00^{2}$

time/ 1 $\circ 0^{3}$

Constant

Number of municipaliy-months

Number of municipalities

Degrees of freedom

Log-likelihood

$\mathrm{AIC}$

** $\mathrm{p}<0.0 \mathrm{I},{ }^{*} \mathrm{p}<0.05$ : one-tailed for the variables for which we have stated a directional hypothesis, and two-tailed for the constant and duration indicators.

\# time-invariant variable.

Note I: To account for repeated measures, all models are estimated with robust standard errors clustered on municipality. Estimated coefficients with standard errors in parentheses beneath.

Note II: Calculations for the percentage change in the odds represent a one-unit change around the mean, holding other

\begin{tabular}{|c|c|c|c|}
\hline $\begin{array}{l}26.539 \\
(22.609)\end{array}$ & $\begin{array}{c}26.293 \\
(22.74 \mathrm{I})\end{array}$ & $\begin{array}{l}21.165^{*} \\
(10.776)\end{array}$ & $\begin{array}{l}2 \mathrm{I} .852^{*} \\
(\mathrm{I} 0.028)\end{array}$ \\
\hline $\begin{array}{l}-392.6 \text { I } 2 \\
(299.8 \circ \text { I })\end{array}$ & $\begin{array}{l}-403.020 \\
(301.444)\end{array}$ & $\begin{array}{l}\text { - I } 72.660 \\
(\text { I62.225) }\end{array}$ & $\begin{array}{l}\text { - I } 50.147 \\
(\text { I } 5 \text { I. } 820)\end{array}$ \\
\hline $\begin{array}{l}2485.839^{*} \\
(1 \circ 42.467)\end{array}$ & $\begin{array}{l}2529.415^{*} \\
(1048.33 \mathrm{I})\end{array}$ & $\begin{array}{l}850.979 \\
(636.544)\end{array}$ & $\begin{array}{l}730.419 \\
(599 \cdot 369)\end{array}$ \\
\hline
\end{tabular}
variables constant at their mean.

$\begin{array}{lcc}-0.026 & 0.030 & +3.0 \% \\ (0.051) & (0.071) & \\ 0.055 & 0.123 & +13.1 \% \\ (0.091) & (0.128) & \end{array}$

$\begin{array}{ccc}0.016^{*} & 0.017^{*} & +1.7 \% \\ (0.008) & (0.007) & \\ 0.180^{*} & 0.167^{*} & +18.1 \% \\ (0.095) & (0.095) & \\ -0.020 & -0.092 & -8.8 \% \\ (0.088) & (0.119) & \\ 0.198^{* *} & 0.204^{* *} & +22.6 \% \\ (0.025) & (0.025) & \end{array}$

$-5 \cdot 35^{* * *}$

$(0.301)$

I 3644

429

$\begin{array}{rr}6 & 5 \\ -\mathrm{I} 002.2 & -\mathrm{I} 004 . \mathrm{I}\end{array}$

$\begin{array}{ll}7 & \text { I } 2\end{array}$

$-952.3 \quad-947.6$
$0.018^{* *}+\mathrm{I} .8 \%$

$.006)$

$0.042+4.3 \%$

(0.059)

\section{$.8 \%$}

(1)


variable is also positive and statistically different from zero. This we interpret as follows: in each month, municipalities that have more municipalities in the same policy network that have already adopted BAG are more likely to adopt BAG themselves. Substantively, within a municipality's network each additional municipality that has adopted BAG is associated with a rise of $21.9 \%$ in the odds of BAG-adoption. Finally, the size-coefficient does not attain conventional levels of statistical significance, and shows that human resources and financial resources are not related to the likelihood of BAG-adoption. This means our resources hypothesis is partially confirmed.

Finally, the results of model 4 in Table 2, where we tested for the effects of motivation, obstacles, and resources in one model, did not substantially alter the results and outcomes described earlier. For the motivational variables the outcomes did not change, except that a one-unit increase in the party alignment variable is now associated with a $\mathrm{r} .8 \%$ increase in the odds ratio of BAG-adoption, compared to a I. I\% increase in model I. Again, the obstacles variables failed to attain conventional levels of statistical significance. The coefficients of the resources variables changed only slightly from the results in model 3 . In model 4 , the odds of BAG-adoption increase by $\mathrm{I} .7 \%$ for every additional unit on the past performance scale, compared to r.6\% in the previous model. The percentage change in odds for the information variable decreased to i $8.1 \%$, compared to i $9.7 \%$ in model 3 . The effect of every additional municipality in the same policy network that had already adopted BAG also changed slightly. In model 4 the odds of adopting BAG is $22.6 \%$, compared to $21.9 \%$ in model 3 .

\section{Discussion and Conclusion}

In the multilevel governance setting of a decentralized unitary state like the Netherlands, municipalities are quite often mandated to adopt innovations. We have shown, by considering the adoption of BAG that the implementation process in the event of a mandated innovation is not 'just' a matter of following a time schedule imposed by central government. We have therefore challenged Berry and Berry's (2007) assertion that national governments' mandated innovations create an uninteresting form of diffusion because local level discretion is supposedly very limited. We show that, even with a limited time frame for municipalities to complete the implementation of this mandated technical and uncontroversial innovation, classical diffusion explanations are important. Indeed, we have shown that there is local independence as well as horizontal interdependence among municipalities, and thus a lot of insight can be gained by studying mandated innovation from a general innovation perspective. Future research should focus on mandated policies in which adopters have more freedom for differentiation in the design and implementation of the policy. It would be interesting to see what local characteristics can explain differences in decisions, because we know from the implementation literature that strategic delay among later adopters in some 
cases meant more responsive or fuller implementation (Goggin, Bowman, Lester, \& O’Toole, I 990 ).

We found that more resourceful municipalities, that is the ones that are better informed, have better past performance, and are included in more extensive policy networks, were more likely to adopt this innovation relatively early. In addition to the internal resources factors, we proved that is was also worth investigating resources external to the municipalities (compare, Berry \& Berry, I 990; Boehmke \& Witmer, 2004; Walker, 2006). The finding that municipalities adopt earlier when there are more municipalities in the same policy network that have already adopted BAG is important for understanding how policies are adopted. We found support for the idea put forward by others that what really matters is the actual place or social network where policy-makers exchange or acquire their information (Füglister, 20 I r b; Sugiyama, 2008). It is important to take into account the role of real existing and functional policy networks, especially in a setting where these learning networks are encouraged, as was the case in our mandated setting.

Motivation matters as well, as we have seen from the findings of our hypothesis that the composition of both local and national governments matter (compare, Berry \& Berry, I 990; Boehmke \& Witmer, 2004). Thus, even for this not politically charged and highly technical innovation, differences in the timing of adoption become visible through political expression. In relation to the degree to which municipalities are motivated, and given their amount of obstacles and resources, we conclude that in the absence of obstacles it is primarily a matter of having sufficient resources available to innovate. It might not be very surprising that motivational factors are less important than resources in making municipalities adopt a topdown innovation. Nevertheless, we think that the degree of political alignment is a relatively underexposed factor when it comes to determining differences in the speed of performing innovative tasks imposed by national government. Furthermore, given our findings, we are convinced that the distinction made by Mohr ( 1 969) (see also: Berry and Berry i 990; Berry and Berry 2007), between motivation, obstacles and resources will be very useful for future research. We expect that for innovations that are politically more pertinent, such as for innovations in social or moral policies, motivation may play a more important role than obstacles and resources when explaining the timing of adoption. Future research should shed light on how such politically sensitive innovations are adopted and whether motivation is indeed more important than for highly technical policies. 


\section{CHAPTER TWO}

\section{REFERENCES}

Ahn, M. J. (20 I I). Adoption of Applications in U.S. Municipalities: The Role of Political Environment, Bureaucratic Structure, and the Nature of Applications. The American Review of Public Administration, 4I (4), 428-452. doi: I 0. I I $77 / 02750740$ I 0377654

Beck, N., Gleditsch, K. S., \& Beardsley, K. (2006). Space is more than geography: Using spatial econometrics in the study of political economy. International Studies Quarterly, 5 O( I), 27-44.

Beetham, D. ( 1 996). Theorizing democracy and local government. In D. King \& G. Stoker (Eds.), Rethinking local democracy (pp. 28-49). Macmillan.

Berry, F. S., \& Berry, W. D. ( 1990$)$. State lottery adoptions as policy innovations: An event history analysis. American Political Science Review, 84(2), 395-4 I 5.

Berry, F. S., \& Berry, W. D. (2007). Innovation and diffusion models in policy research. In P. A. Sabatier (Ed.), Theories of the Policy Process (second., pp. 223-260). Boulder, CO: Westview Press.

BMC Consultancy and Management. (2006). Baseline measurement Basic Registration Addresses and Buildings [In Dutch: Nulmeting BAG].

Boehmke, F. J., \& Witmer, R. (2004). Disentangling diffusion: The effects of social learning and economic competition on State policy innovation and expansion. Political Research Quarterly, 57 ( I), 39-5 I. doi: I 0. I I 77/I06591290405700104

Brooks, S. M. (2005). Interdependent and domestic foundations of policy change: The diffusion of pension privatization around the world. International Studies Quarterly, 49(2), 273-294.

Buckley, J., \& Westerland, C. (2004). Duration Dependence, Functional Form, and Corrected Standard Errors: Improving EHA Models of State Policy Diffusion. State Politics \& Policy Quarterly, 4( I), 94-I I 3. doi: I 0. I I 77/I 53244000400400105

BZK. (2008a). Distribution of payments from the Municipal fund [In Dutch: Verdeling van de uitkeringen uit het gemeentefonds] [Data file]. Retrieved from http://www.rijksoverheid.nl/onderwerpen/gemeenten/documenten-enpublicaties/rapporten/20 I I/०7/28/verdeling-van-de-uitkeringen-uit-het-gemeentefonds.html

BZK. (2008b). Municipalities' budget analyses [In Dutch: Begrotingsanalyse gemeenten] [Data file]. Retrieved August 2 I, 20 I 2, from http://www.rijksoverheid.nl/documenten-en-publicaties/rapporten/

Carter, D. B., \& Signorino, C. S. (2० I o). Back to the future: Modeling time dependence in binary data. Political Analysis, I 8(3), 27 I-292. doi: I o. I 093/pan/mpqo I 3

Daley, D. M., \& Garand, J. C. (2005). Horizontal diffusion, vertical diffusion, and internal pressure in state environmental policymaking, i 989-1 998. American Politics Research, 33(5), 6 I 5-644. doi: I O.I I 77 / I $532673 \times 042734$ I 6

Denters, B. (2005). Towards local governance? In B. Denters \& L. E. Rose (Eds.), Comparing local governance: Trends and developments (pp. 246-262). New York, NY: Palgrave Macmillan.

Denters, B., \& Mossberger, K. (2006). Building blocks for a methodology for comparative urban political research. Urban Affairs Review, 4 I (4), $55^{\circ}$.

E-overheid.nl. (20 I 2). Ambulances navigate on BAG [In Dutch: Ambulances navigeren op de BAG]. Retrieved from http://www.e-overheid.nl/actueel/nieuwsberichten/intItem/ambulances-navigeren-op-de-bag-/ i 430

Fliegel, F. C., \& Kivlin, J. E. (1 966). Attributes of Innovations as Factors in Diffusion. American Journal of Sociology, $72(3), 235-248$.

Füglister, K. (20 I I a). Cantons as Policy Laboratories of the Federal State? The Diffusion of Health Insurance Subsidy Policies among the Swiss Cantons. Dissertation. University of Zürich.

Füglister, K. (20 I I b). Where does learning take place? The role of intergovernmental cooperation in policy diffusion. European Journal of Political Research, 5 I(3), 3 I 6-349. doi: I o. I I I I/j. I 475-6765.20 I I.02000.x

Goggin, M. L., Bowman, A. O., Lester, J. P., \& O’Toole, L. ( I 990). Implementation theory and practice: Toward a third generation. Glenview, IL: Scott, Foresman/Little, Brown Higher Education.

Goldsmith, M. (2005). A new Intergovernmentalism? In B. Denters \& L. E. Rose (Eds.), Comparing local governance: Trends and developments (pp. 228-245). New York, NY: Palgrave Macmillan.

Goldsmith, M., \& Page, E. C. (2०1०). Changing government relations in Europe: From localism to intergovernmentalism. London, England: Routledge. 
Goldthorpe, J. H. ( I 996). The quantitative analysis of large-scale data-sets and rational action theory: For a sociological alliance. European Sociological Review, I2(2), I09-1 26.

Gray, V. ( I 973). Innovation in the states: A diffusion study. The American Political Science Review, 67(4), I I 74 -I I 85.

Gray, V. ( I 994). Competition, emulation, and policy innovation. In L. C. Dodd \& C. Jillson (Eds.), New perspectives on American politics (pp. 230-248). Washington, DC: Congressional Quarterly.

Hansen, M. B. (20 I I). Antecedents of organizational innovation: The diffusion of new public management into Danish local government. Public Administration, 89(2), 28 5-306. doi: I 0. I I I I/j. I 467-9299.20 I 0.0 I 855.x

Homburg, V., Dijkshoorn, A., \& Thaens, M. (20 I 3). Diffusion of Personalised Services among Dutch Municipalities: Evolving Channels of Persuasion. Local Government Studies, I-22. doi: I 0. I $080 / 03003930.2013 .795892$

ICTU. (2007-20 I ). E-Government ranking municipalities [In Dutch: Overheid.nl monitor gemeenten] [Data file]. Retrieved March 22, 20 I I , from http://www.e-overheid.nl/onderwerpen/voortgang-en-planning/overheidnlmonitor/gemeenten

Kamerstukken II. (2005-2006). Bijlage bij Kamerstuk 29362, (nr. 90), I-7. Retrieved from https://zoek.officielebekendmakingen.nl/kst-29362-9o-br.html

Karch, A. (2006). National intervention and the diffusion of policy innovations. American Politics Research, 34(4), 403426. doi: I O. I I 77/1 532673 X06288202

Karch, A. (2007a). Democratic Laboratories. Policy diffusion among the American states. Ann Arbor: The University of Michigan Press.

Karch, A. (2007b). Emerging Issues and Future Directions in State Policy Diffusion Research. State Politics E Policy Quarterly, 7(I), 54-80. doi: I 0.I I 77/I 53244000700700 I04

Kiesraad. (20 I I). Election Results. [In Dutch: Verkiezingsuitslagen] [Data file]. Retrieved May I 3, 20 I 4, from http://www.verkiezingsuitslagen.nl/Na I 9 I 8/Verkiezingsuitslagen.aspx/

Krause, R. M. (20 I I). Policy Innovation, Intergovernmental Relations, and the Adoption of Climate Protection Initiatives By U.S. Cities. Journal of Urban Affairs, 33 ( I ), 45-60. doi: I 0. I I I I/j. I 467-9906.20 I 0.005 I 0.x

Laakso, M., \& Taagepera, R. ( I 979). The "effective” number of parties: “A measure with application to West Europe.” Comparative Political Studies, I 2 ( I), 3.

Makse, T., \& Volden, C. (2० I I). The Role of Policy Attributes in the Diffusion of Innovations. The Journal of Politics, 73 (०I), I 08 -I 24. doi: I 0.1 1 I 7/S०02238 I6 10000903

McNeal, R. S., Tolbert, C. J., Mossberger, K., \& Dotterweich, L. J. (2003). Innovating in digital government in the American states. Social Science Quarterly, 84( I), 52-70.

Mohr, L. B. ( 1 969). Determinants of innovation in organizations. The American Political Science Review, 63 ( I), I I II 26.

Moon, M. J. (2002). The evolution of e-government among municipalities: Rhetoric or reality? Public Administration Review, 62(4), 424-433.

Norris, D. F., \& Moon, M. J. (2005). Advancing e-government at the grassroots: tortoise or hare? Public Administration Review, 65( I), 64-75.

Pollitt, C., \& Bouckaert, G. (2004). Public management reform: a comparative analysis (2nd ed.). Oxford University Press.

Rogers, E. M. (2003). Diffusion of innovations (5th ed.). New York: Free Press.

Sapat, A. (2004). Devolution and innovation: The adoption of state environmental policy innovations by administrative agencies. Public Administration Review, 64(2), I 4 I - I 5 I. doi: I O. I I I I/j. I 540-62 I 0.2004.00356.x

Singer, J. D., \& Willett, J. B. (2003). Applied longitudinal data analysis. New York, NY: Oxford University Press.

Soss, J., Schram, S. F., Vartanian, T. P., O’Brien, E., Brien, E. O., \& Mawr, B. (200 I). Setting the Terms of Relief: Explaining State Policy Choices in the Devolution Revolution. American Journal of Political Science, 45(2), 378395 .

Statistics Netherlands. (20 I I). The Netherlands regional. [In Dutch: Nederland regionaal] [Data file]. Retrieved August 2 I, 20 I 2 , from http://www.statline.cbs.nl/

Sugiyama, N. B. (2008). Theories of policy diffusion: Social sector reform in Brazil. Comparative Political Studies, 4 I (2), I 93-2 I6. doi: I 0. I I 77/00 I04 I 40073009I6

Traut, C. A., \& Emmert, C. F. (2003). Death Penalty Exemptions for Juveniles: An Event History Analysis of State Policy Adoption. Politics E Policy, 3 I (2), 296-3 I 2. doi: I o. I I I I j. I 747- I 346.2003.tboo I 50.x 


\section{CHAPTER TWO}

Volden, C. (2006). States as policy laboratories: Emulating success in the children's health insurance program. American Journal of Political Science, 50(2), 294-3 12.

VROM. (2009). Legal arrangement Basic Registrations Addresses and Buildings [In Dutch: Regeling Basisregistraties Adressen en Gebouwen]. Minister van Volkshuisvesting, Ruimtelijke Ordening en Milieubeheer, 8 juni 2009, nr. BJZ2009038757. Retrieved from http://wetten.overheid.nl/BWBRo०2596 I

VROM. (2० I I). Adoption dates of all municipalities [In Dutch: Plandata BAG van alle Gemeenten]. Ministerie van Volkshuisvesting, Ruimtelijke Ordening en Milieubeheer. Retrieved April I 9, 20 I I , from http://bag.vrom.nl/

Walker, J. L. ( 1 969). Diffusion of innovations among American States. American Political Science Review, 63(3), 880899.

Walker, R. M. (2006). Innovation type and diffusion: An empirical analysis of local government. Public Administration, 84(2), 3 I I-335. doi: I 0. I I I I/j. I 467-9299.2006.00004.X

Walker, R. M., Avellaneda, C. N., \& Berry, F. S. (20 I I). Exploring the diffusion of innovation among high and low

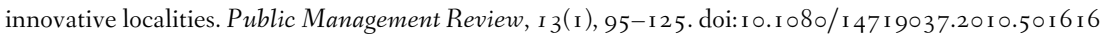

Weare, C., Musso, J. a., \& Hale, M. L. ( I 999). Electronic Democracy and the Diffusion of Municipal Web Pages in California. Administration E Society, 3I(3), 3-27. doi: I O. I I 77/009539999400935475 
APPENDIX I. Major events and timelines of the adoption of BAG

\begin{tabular}{|c|c|c|c|c|c|}
\hline \multirow[t]{2}{*}{ Event } & \multirow[t]{2}{*}{ Timeline } & \multirow[t]{2}{*}{ Months } & \multicolumn{3}{|c|}{ BAG-adoptions } \\
\hline & & & \# of mun. & $\%$ of mun. & $\%$ change \\
\hline \multirow{4}{*}{$\begin{array}{l}\text { Legislation } \\
\text { I }^{\text {st }} \text { deadline }\end{array}$} & January 24,2008 & $\circ$ & $\circ$ & $\circ$ & $\circ$ \\
\hline & July I, 2009 & I 7 & 4 & I & I \\
\hline & July I, 20 I० & 29 & 63 & 15 & I 4 \\
\hline & December I, 20 I & 34 & 248 & 58 & 43 \\
\hline \multirow[t]{2}{*}{$2^{\text {nd }}$ deadline } & January I, 20 I I & 35 & 4 I 5 & 97 & 39 \\
\hline & April 8, 20 I I & 38 & 429 & 100 & 3 \\
\hline
\end{tabular}


APPENDIX II. BAG-adoption by month

\begin{tabular}{|c|c|c|c|}
\hline $\begin{array}{l}\text { Time } \\
\text { Month }\end{array}$ & $\begin{array}{l}\text { Number } \\
\text { of Adopters }\end{array}$ & $\begin{array}{l}\text { At risk } \\
\text { of adoption }\end{array}$ & $\begin{array}{l}\text { Hazard } \\
\text { probability }\end{array}$ \\
\hline I & $\circ$ & 429 & 0.0000 \\
\hline 2 & ० & 429 & 0.0000 \\
\hline 3 & ○ & 429 & 0.0000 \\
\hline 4 & $\circ$ & 429 & 0.0000 \\
\hline 5 & $\circ$ & 429 & 0.0000 \\
\hline 6 & I & 428 & $0.000 \mathrm{I}$ \\
\hline 7 & ○ & 428 & 0.0000 \\
\hline 8 & ○ & 428 & 0.0000 \\
\hline 9 & $\circ$ & 428 & 0.0000 \\
\hline IO & $\circ$ & 428 & 0.0000 \\
\hline I I & $\circ$ & 428 & 0.0000 \\
\hline I 2 & ○ & 428 & 0.0000 \\
\hline 13 & $\circ$ & 428 & 0.0000 \\
\hline I 4 & $\circ$ & 428 & 0.0000 \\
\hline I 5 & I & 427 & $0.000 \mathrm{I}$ \\
\hline I 6 & I & 426 & $0.000 \mathrm{I}$ \\
\hline I 7 & I & 425 & $0.000 \mathrm{I}$ \\
\hline I 8 & 2 & 423 & 0.0003 \\
\hline I9 & I & 422 & 0.0002 \\
\hline 20 & 3 & 419 & 0.0005 \\
\hline $2 \mathrm{I}$ & 7 & 412 & $0.00 \mathrm{I} 4$ \\
\hline 22 & 6 & 406 & 0.0013 \\
\hline 23 & 6 & 400 & $0.00 \mathrm{I} 4$ \\
\hline 24 & 7 & 393 & 0.0018 \\
\hline 25 & I & 392 & 0.0003 \\
\hline 26 & 7 & 385 & 0.0023 \\
\hline 27 & 6 & 379 & 0.0022 \\
\hline 28 & IO & 369 & 0.0044 \\
\hline 29 & I 7 & $35^{2}$ & 0.0089 \\
\hline 30 & I 5 & 337 & 0.0097 \\
\hline $3 \mathrm{I}$ & $3 \mathrm{I}$ & 306 & 0.026 I \\
\hline 32 & $4 \mathrm{I}$ & 265 & 0.0482 \\
\hline 33 & 59 & 206 & $0.1 \circ 83$ \\
\hline 34 & I 39 & 67 & 0.4964 \\
\hline 35 & 63 & 4 & 0.85 I 4 \\
\hline 36 & 2 & 2 & 0.2857 \\
\hline 37 & I & I & 0.3333 \\
\hline 38 & I & $\circ$ & 1.0000 \\
\hline
\end{tabular}




\section{APPENDIX III. Justification for the specification of the control variable time}

Comparison of alternative smooth polynomial representations for the main effect of time (MONTHS) in a baseline discrete-time hazard model ( $\mathrm{N}$ observations=13,644, $\mathrm{N}$ events $=429$ )

\begin{tabular}{|c|c|c|c|c|c|c|c|}
\hline \multirow[b]{2}{*}{$\begin{array}{l}\text { Representation } \\
\text { time }\end{array}$} & \multirow[b]{2}{*}{ for } & \multirow[b]{2}{*}{$n$ paramenters } & \multirow[b]{2}{*}{ Deviance } & \multicolumn{2}{|c|}{$\begin{array}{c}\text { Difference in deviance in } \\
\text { comparison to ... }\end{array}$} & \multirow[b]{2}{*}{ AIC } & \multirow[b]{2}{*}{$\mathrm{BIC}$} \\
\hline & & & & $\begin{array}{l}\text { Previous } \\
\text { model }\end{array}$ & $\begin{array}{l}\text { General } \\
\text { model }\end{array}$ & & \\
\hline Constant & & I & 3812.70 & $\begin{array}{c}-- \\
--\end{array}$ & I 886.35 & 3814.70 & 3818.74 \\
\hline Linear & & 2 & 2178.30 & I634.39 & 251.95 & 2182.30 & 2190.43 \\
\hline Quadratic & & 3 & $2098.2 \mathrm{I}$ & 80.09 & I 7 I .86 & $2 \mathrm{I} \circ 4.2 \mathrm{I}$ & 2116.39 \\
\hline Cubic & & 4 & 2008.68 & 89.53 & 82.33 & 2016.68 & 2032.92 \\
\hline General & & 24 & I 926.35 & --- & --- & I 974.35 & 2071.83 \\
\hline
\end{tabular}

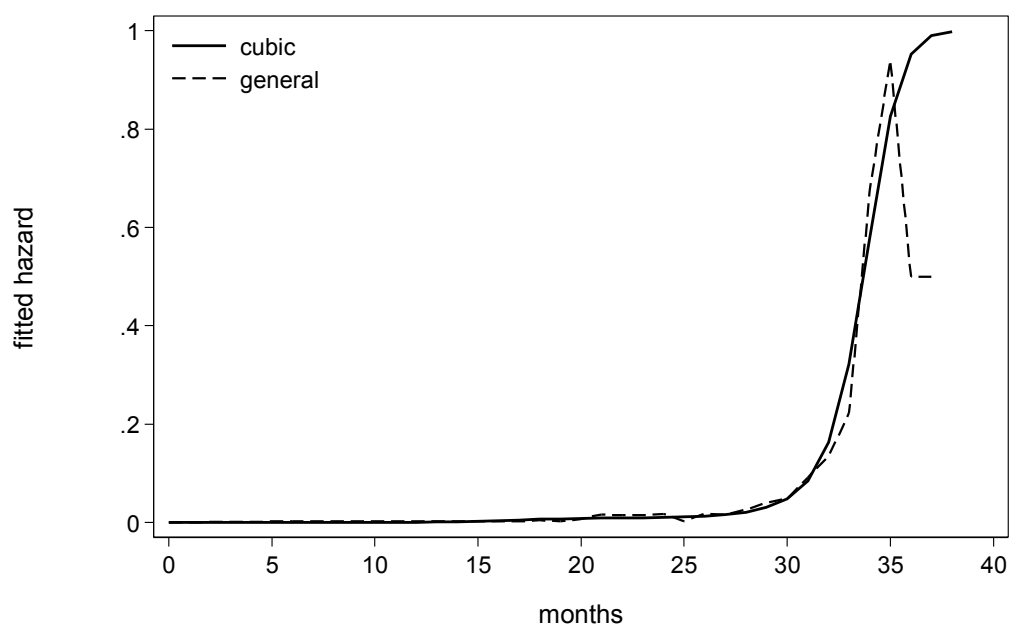

Fitted hazard function for number of months until BAG adoption, with cubic polynomial for the main effect of time (MONTHS). 


\section{CHAPTER TWO}

\section{NOTES}

${ }^{1}$ There were neither incentives nor disincentives for fast or slow municipalities, except that municipalities connecting to the nationwide BAG facility in $20 \mathrm{I}$ I had to pay for the audit themselves. However, by the end of the year $20 \mathrm{I} \circ$, the Ministry of VROM intensified the guidance and support for possible late adopters.

${ }^{2}$ Because we define the adoption of a policy new to the respective municipality as innovation, we are aware that the adoption of a mandated policy might be less of an innovation than the voluntary adoption of a new policy. Nevertheless, we argue that they both represent a certain level of readiness to engage in policy change.

${ }^{3}$ In line with rational choice theory, and in line with Mohr ( 1969 ), we assume methodological individualism, which means that we consider municipalities as unified decision makers. We abstract from the individual actors within a municipality to the organization as a whole, which allows for ascribing the concepts of motivation, obstacles and resources to municipalities.

${ }^{4}$ In the final overview of VROM 'Adoption dates of all municipalities' [In Dutch: Plandata BAG van alle Gemeenten] there were 429 municipalities that had adopted BAG. In the period of our study there was a reduction in the number of municipalities, due to municipal amalgamation. There were 443 municipalities in 2008 , 44 I municipalities in 2009, 43 I municipalities in 20I0, and 4 I 8 municipalities in $20 \mathrm{I} \mathrm{I.} \mathrm{We} \mathrm{consider} \mathrm{this} \mathrm{not} \mathrm{to} \mathrm{be} \mathrm{a} \mathrm{problem} \mathrm{because} \mathrm{our}$ statistical method (EHA) only requires information about municipalities up to the moment of adoption. For example, Abcoude adopted BAG in $20 \mathrm{I} \circ$ (month 33) and amalgamated in January $20 \mathrm{I}$; t this means that the amalgamation does not influence our data collection because Abcoude is 'at risk' until month 33, and from the next month is removed from our dataset.

${ }^{5}$ In October 2005 all Dutch municipalities $(\mathrm{N}=467)$ were phoned by BMC Consultancy and Management and introduced to the survey "Baseline measurement Basic Registration Addresses and Buildings" [In Dutch: Nulmeting BAG]. Hereafter municipalities were asked which official could be approached as a contact person. All theses contacts were asked, by e-mail, to complete the online questionnaire. The exact question asked for this variable was: "What rating would you give to the current quality of the addresses registration in your municipality (scale of I to I $\circ$; $\mathrm{I}=$ lowest, I $\circ$ is highest rating)". We are aware the question asked is a subjective measurement of problem severity, but we assume that someone designated as a contact person by the municipality itself could make a good estimatewhen answering this question. Because we wanted to keep as many municipalities as possible in the analysis, for 148 municipalities we replaced the missing value with the average score of all other municipalities. This adjustment did not alter the outcomes of our results. Furthermore, although this variable was measured at the beginning of 2006, and BAG legislation came into effect in 2008, in our view it is a good baseline measurement that is able to distinguish between municiaplities.

${ }^{6}$ National elections were held in November 2006, and June 2010. Local elections were held in March 2006, and March 20I०. From January 2008 (month I) to June 20 I $($ month 24) we compare the results of the local elections in 2006 with the results of the national elections in 2006 . From July $20 \mathrm{I} \circ$ (month 25 ) to April 20 I I (month 38 ) we compare results from the local elections in $20 \mathrm{I} \circ$ with the results of the national elections in $20 \mathrm{I} \circ$. For some municipalities values were missing $(\mathrm{N}=29$ in 2006 and $\mathrm{N}=34$ in $20 \mathrm{I} 0$ ). Because most missing values were due to amalgamation, we were able to find election results (from other dates, but valid in the same periods) on municipalities' websites.

${ }^{7}$ Local elections were held in March 2006, and March $20 \mathrm{I}$. From January 2008 (month I) to June $20 \mathrm{I} \circ$ (month 24) we use the results of the local elections in 2006, and from July 20 I 0 (month 25) to April 20 I I (month 38) we use results from the local elections in 20 г 0 . For some municipalities values were missing ( $N=29$ in 2006 and $N=34$ in 20 I 0 ). Because most missing values were due to amalgamation we were able to find election results (from other dates, but valid in the same period) on municipalities' websites.

${ }^{8}$ Although the number of buildings is measured at the end of $20 \mathrm{I}$ I, and BAG-adoptions took place between the end of 2008 and the beginning of $20 \mathrm{I} \mathrm{I}$, we consider it to be a good estimate because it is not a variable that is substantially subject to change. Also, the fact is that the number of buildings per municipality only became known after entering the buildings in the database (put differently, it does not measure progress for the filling of the database, it measures only the final amount). To decrease the influence of municipalities with many buildings we use a log-transformation.

9 The E-Government Monitors of 2007 and 2009 are examined by Daadkracht in cooperation with TNS NIPO, and is commissioned by ICTU (program Overheid heeft Antwoord(C) / BZK). The E-Government Monitor of 2008 is examined by Panteia and commissioned by ICTU (program Overheid heeft Antwoord(C) / BZK). The E-Government Monitor of $20 \mathrm{I} \circ$ is examined by Daadkracht in cooperation with TNS NIPO, and is commissioned by ICTU (program RENOIR / BZK). In the last months of every year researchers examined the websites of all Dutch municipalities using a standard questionnaire. In 2007 the standard questionnaire consisted of five main themes that were reviewed on the basis of 78 aspects ( $\mathrm{I}$. Standards ( $\mathrm{N}$ of questions $=9$, relative importance $=15 \%$ ); 2. Public access to government information, and citizen involvement $(\mathrm{N}$ of questions $=29$, relative importance $=15 \%)$; . Service provision $(\mathrm{N}$ of questions $=8$, relative importance $=25 \%) ; 4$. Personalized service provision $(\mathrm{N}$ of questions $=8$, relative importance $=20 \%) ; 5$. Participation $(\mathrm{N}$ of questions $=5$, relative importance $=\mathrm{I} 0 \%) ; 6$. Accessibility $(\mathrm{N}$ of questions $=\mathrm{I}$, relative importance $=\mathrm{I} 5 \%)$. 
In 2008 the standard questionnaire consisted of five main themes that were reviewed on the basis of 89 aspects ( $\mathrm{I}$. Standards $(\mathrm{N}$ of questions $=\mathrm{I} 2$, relative importance $=15 \%) ; 2$. Transparency: public access to government information ( $\mathrm{N}$ of questions = I 9, relative importance $=15 \%) ; 3$. Service provision $(\mathrm{N}$ of questions $=34$, relative importance $=20 \%) ; 4$. Personalised service provision $(\mathrm{N}$ of questions $=9$, relative importance $=15 \%)$; . Citizen involvement and participation $\left(\mathrm{N}\right.$ of questions $=\mathrm{I}_{3}$, relative importance $\left.=20 \%\right) ; 6$. Accessibility $\left(\mathrm{N}\right.$ of questions $=2$, relative importance $\left.=\mathrm{I}_{5} \%\right)$. In 2009 and 2010 the standard questionnaire consisted of five main themes which were reviewed on the basis of I०I aspects $(\mathrm{I}$. Standards $(\mathrm{N}$ of questions $=$ I 3, relative importance $=$ I $7 \%) ; 2$. Transparency: public access to government information $(\mathrm{N}$ of questions $=12$, relative importance $=15 \%)$; 3 . Service provision $(\mathrm{N}$ of questions $=33$, relative importance $=25 \%) ; 4$. The citizen centered $(\mathrm{N}$ of questions $=29$, relative importance $=25 \%) ; 5$. Interactive references $(\mathrm{N}$ of questions $=7$, relative importance $=3 \%) ; 6$. Accessibility $(\mathrm{N}$ of questions $=7$, relative importance $=15 \%)$. Missing values were replaced with scores from later years $(\mathrm{N}=4$ in 2007 and $\mathrm{N}=4$ in 2008).

${ }^{10}$ For this variable, the same background knowledge applies as for the variable problem severity discussed in footnote three. We are aware the question asked is a subjective measurement of information, but we assume that the person designated as a contact person by the municipality itself is the most important person for the ingestion of information provided by VROM. The exact questions asked were: "Do you know the website bag.vrom.nl?", and "Are you subscribed to the newsletter about the basic registrations addresses and buildings?" To keep as many municipalities as possible in the analysis, for ro8 municipalities we replaced the missing value with the average score of all other municipalities. This adjustment did not alter the outcomes of our results. Furthermore, as BAG legislation came into effect in 2008, and this variable was measured at the beginning of 2006 , it is possible that municipalities began to familiarize themselves with the BAG website and the BAG newsletter after legislation was passed. Since we have not been able to solve any such misspecification (that is, the timing of when municipalities took steps to acquire more information could have affected the timing of BAG-adoptions) it is possible that this variable might not adequately measures what it wants to.

${ }^{11}$ For size we used three measures; total population, fulltime-equivalent and municipal fund. Total population was $\log$ transformed to decrease the influence of larger municipalities, and after that transferred into $\mathrm{z}$-scores. Missing values were replaced with values from later years $(\mathrm{N}=5$ in 2008 and $N=3$ in 2009). FTE was $\log$ transformed to decrease the influence of larger municipalities, and after that transferred into z-scores. Missing values were replaced with values from later years $(\mathrm{N}=\mathrm{I}$ in 2008 and $\mathrm{N}=\mathrm{I}$ in 2009). Municipal fund was log transformed to decrease the influence of larger municipalities. Missing values were replaced with values from later years ( $N=5$ in 2008 and $N=3$ in 2009). A factor analysis and a subsequent reliability test indicated that one size scale could be constructed (for all years: $\alpha>0.786$ and eigenvalue $>2.174)$.

${ }^{12}$ The Ministry of VROM developed, together with a few pilot municipalities, a guidebook for other municipalities to help prevent common pitfalls. Municipalities that participated in the BAG pilot project were; Amstelveen, Apeldoorn, Arnhem, Barneveld, Borne, Boxmeer, Doetinchem, Eindhoven, Haarlemmermeer, Helmond, Horst aan de Maas, Lelystad, Nieuwegein, Reiderland, Scheemda, Tilburg, Vlaardingen, Waalre and Winschoten. These municipalities had already begun work on their implementation of BAG in 2006. The ministry of VROM did not select the municipalities randomly to act as a pilot; it was the state of progress of BAG implementation that formed the basis for selection.

${ }^{13}$ The table in Appendix III shows a comparison of alternative specifications for time (based on calculations proposed by Singer and Willett (2003, Chapter I 2)) on which basis (the chi-square value for the deviance statistic is way above the critical value for the $०$.० I significance level for both the model for the cubic polynomial compared to the quadratic polynomial, and for the cubic polynomial model compared to the model with time dummies (general)) we conclude that the model with the cubic polynomial (cubic) for time functions best, as it performs almost as well as the model with time dummies (general), and that given its lowest values for AIC and BIC it outperforms the quadratic polynomial (quadratic) for time. The figure in Appendix III shows us that the cubic polynomial of time is quite capable of recovering the baseline hazard. This is in line with recent methodological advice by Carter and Signorino (2० I ०).

${ }^{14}$ Results are robust to the alternatives of probit and complementary log-log (cloglog) models (Buckley \& Westerland). 



\section{CHAPTER 3. YOUTH POLICY INNOVATION IN THE NETHERLANDS: THE REALIZATION OF CENTERS FOR YOUTH AND FAMILIES BY MUNICIPALITIES'}

\section{ABSTRACT}

In cases of policy decentralization from national to local governments, the decentralizationthesis easily argues that local priorities and local circumstances determine differences in policy development. In this study, we examine this thesis by examining the conditions affecting the timing of the realization of Centers for Youth and Family (CYFs) in the Netherlands between 2008 and 20I2. We found considerable differences among municipalities in the timing of the realization of CYFs. In explaining these differences, we assumed motivations to be more important than obstacles and resources, because municipalities received financial compensation, and because CYFs can be considered as a social policy innovation. Our findings indicate that the degree of political alignment between the municipal council and national government is an important motivation, and that increasing numbers of adopting municipalities in the same policy network and organizational capacity were important resources. Thus, opposite to what theory suggested, we found that resources were more important than motivations for the realization of CYFs. These findings challenge the decentralization-thesis.

\section{Background and research questions}

From the I990's onwards, many responsibilities for youth care in the Netherlands were transferred to the municipalities. These decentralizations were based on the assumption that efficiency and effectiveness of youth policies would increase if care was provided as closely as possible to the home of care users (Gilsing, 2007; Timmerman, 2009; van Montfoort \& Tilanus, 2007). In recent years, in the Netherlands as well as in other European countries, on the basis of rather similar arguments (De Vries, 2000; Pollitt, 2005), many other policy responsibilities were decentralized to local governments (Denters, 2005; Pollitt \& Bouckaert, 2004). Typically, such decentralizations are based on the argument that local authorities are better able than other tiers of government to tailor policies to differences in local circumstances. Local governments are furthermore assumed to be responsive to local political priorities and the demands of local residents. However, this assumption needs empirical

\footnotetext{
'Jans, W., Need, A., Van Gerven, M., \& Denters, B. (201 5). Youth policy innovation in the Netherlands: The realization of Centers for Youth and Families by municipalities. Manuscript submitted for publication.
} 
testing. An important question is to what extent local conditions have actual importance in the implementation process of new policies. We will answer this general question by examining one part of the Dutch decentralization of Youth policy: the realization of Centers for Youth and Family (CYFs) (In Dutch: Centra voor Jeugd en Gezin) in municipalities between 2008 and $20 \mathrm{I} 2$.

Raising concerns about the quality of youth care and the quality of collaboration between different partners in the caring for young people (Eijck, 2006), led to the appointment of an advisory committee for the government: 'Operation Young' (In Dutch: Operatie Jong), which issued from the cooperation between all the Ministries involved in youth care. ${ }^{\text {I }} \mathrm{With}$ the inauguration of cabinet Balkenende IV (2006-20 I O) several advices from this committee were introduced. This cabinet, composed of the coalition partners Christian Democrats (CDA), Labour Party (PvdA), and Christian Union (CU), had a strong focus on developing youth and family policies (AZ, 2007). In this cabinet term, the willingness to introduce youth and family policies -based on advice from the advisory committee, led to a new and temporary Ministry: the so-called program-Ministry for Youth and Family (In Dutch: Programmaministerie voor Jeugd en Gezin - hereafter referred to as Y\&F). The Minister of Y\&F was André Rouvoet from the CU. Already in the subsequent government term (Rutte I, 20 I0-20 I 2) the new Ministry was abolished and existing responsibilities were transferred to other Ministries. The main goals of the Ministry of Y\&F were to increase the quality of youth care and to increase the collaboration between different partners in youth care, and also to provide parenting advice and support for all families (Eijck, 2006; J\&G, 2007). The policy program of the Ministry of Y\&F 'All opportunities, for all children' proposed that by the end of the year 20 I I there should be a nationwide network of CYFs to provide parenting support to parents and educators (J\&G, 2007). In several other European countries, such as Belgium, France, Germany, and the UK, a Ministry comparable to the Dutch Ministry of Y\&F has or still continues to exist. ${ }^{2}$ Also, in the countries Finland, Belgium, Germany and the UK there were initiatives quite similar to the CYFs in the Netherlands (Dijk, Kalsbeek, Prinsen, \& Nota, 2008). In the UK, for example, local governments were held responsible for the implementation of so-called Children Centre's, which are integrated facilities designed for parents and unborn children and children to about 5 years old (Vink, 2007). Municipalities in the Netherlands were made responsible for the realization of a CYF within its municipal boundaries (J\&G, 2008), and for its implementation municipalities received the financial means from the so-called Broad Goal-oriented Grant Youth and Family (In Dutch: Brede Doeluitkering Jeugd en Gezin). At least one recognizable physical place in which organizations responsible for youth health care collaboratively offered their services to citizens needed to be provided by municipalities by the end of $20 \mathrm{I}$ I. The realization of CYFs in Dutch municipalities provides an ideal opportunity to investigate local governments' reactions to a national mandate for the implementation of new policies, and the extent to which local priorities and local needs affect the timing of such implementations. 
When local governments are required to implement a by national government mandated policy, they could in principle learn from what other local governments' did before them. When governments learn from one another's policy implementation, policies diffuse when they get adopted and implemented by different governments (Karch, 2007a; Volden, 2006). We call the newly implemented policies policy innovations, since they concern ideas or practices that are perceived as new to the actors adopting it, regardless of other actors having already adopted it (Gray, I 994). In this paper we study the actual implementation of an innovation - the CYFs - instead of only the adoption decision. What we investigate is the result of an adoption and implementation process eventually leading to the realization of a CYF. Usually, early adopters are considered to be more innovative than later adopters (Rogers, 2003). We investigate why some municipalities are more innovative in youth policy implementation than others, by answering two research questions: (I) To what extent do differences exist among Dutch municipalities in the timing of the realization of a CYF? and (2) How can we explain differences in the timing of the realization of CYFs among Dutch municipalities?

Previous research has typically focused on the voluntary adoption of polices, in which the cumulative number of innovations over time is often characterized by an s-shaped learning curve (Rogers, 2003). However, local governments are often required to adopt and implement innovations in a specific manner or by a specific time, because higher levels of authority decided so. It has been argued that such national mandates effectively bring an end to the diffusion process, because it leaves local governments no choice but to adopt a particular policy innovation (Karch, 2006, p. 406). Mandated policy innovations are therefore believed to be a "highly uninteresting form of diffusion, as nearly all state discretion is eliminated by national-level fiat" (Berry \& Berry, 2007, p. 23 I ). Contrary to this conventional belief, we argue that mandated policy innovations are important cases to study. First, we cannot assume that municipalities act precisely as they are instructed to; generally they will have at least some discretion in performing their mandatory tasks (Goldsmith \& Page, 20 I ०; Goldsmith, 2005). Second, national mandates that shift policy responsibilities to local governments do not imply by definition that all local governments' responses are similar. For example, there can be differences in the utilization of a policy (Boyne, Gould-Williams, Law, \& Walker, 2005; Soss, Schram, Vartanian, \& O’Brien, 200 I), or when there is no discretion regarding the substance of the innovation, there may be differences in terms of the timing of the adoption (Jans, Denters, Need, \& van Gerven, n.d.). In the context of mandated innovations, reasons for variations in adoption are important to investigate, because the innovation adoption process is not just simple and straightforward (Boyne et al., 2005).

It has been repeatedly empirically identified that both motivations and resources play an important role when governments adopt innovations (Berry \& Berry, 2007). However, the impact of certain types of explanations can differ depending on the type of innovation under 
investigation (Gray, I973). In this paper, we examine the implementation of a mandated social policy, which directly affects the wellbeing of citizens. That provides an interesting test case. For mandated policies we would expect that primarily resources play a role in realizing the innovation, because there is no choice but to adopt the innovation. However, in the case of the CYFs the municipalities received financial compensation for the realization of these centers. Moreover, in the case of a social policy one would expect motivational both political and ideological - to be more important than the resources. This paper therefore provides an ideal test case to examine the conditions under which motivations are more important than are resources when it comes to implementing mandated social policies.

\section{Theory and Hypotheses}

To explain variations in the timing of the realization of CYFs between municipalities we will derive predictions from rational choice theory as postulated by Mohr ( I 969, p. I I 4), who states that motivation and resources are positively related to innovation, and that obstacles are negatively related to innovation (see also, Berry \& Berry, 2007). In the case of realizing CYF's in municipalities this means that when the willingness to realize them is high, obstacles that can delay realization are small, and the available resources are large, the probability of municipalities realizing a CYF will be high. Rational choice explanations assume that when actors face problems they will select solutions that are, given the circumstances, best in line with their preferences and desires (Hedström, 2005, p. 6r I). This is also applicable to our case; after all, municipalities are able to determine the moment of adoption.

Rational choice theory considers the motivations, resources and obstacles of municipalities to consist of both internal and external factors (Berry \& Berry, I 990). Internal factors often refer to a governments political, economic, and societal conditions (Berry \& Berry, 2007). External mechanisms refer to the idea that governments learn from each other's policy experimentations. There is a substantial amount of evidence of governments learning from other governments (Shipan \& Volden, 20 I2). Allard (2004), for example, found that state decisions regarding Mothers' Aid programs were followed by similar decisions in neighboring states. Sugiyama (2008) showed that social programs diffuse across Brazil, due to public officials who adhere to policy favorable professional norms because of socialization in professional networks. For mandated innovations, it is important to study the possible effects of external intergovernmental factors in addition to internal factors. It can be expected that when local governments are all charged with the same assignment, they will watch each other closely. Furthermore, in performing mandated tasks, local governments are generally closely monitored by the national government. It has been found, for example, that local governments whose political composition more closely resembled that of the national government were quickest to obey to mandated tasks (Jans et al., n.d.). 
As argued above, the impact of motivations, resources and obstacles differs between policy areas (compare, Damanpour \& Schneider, 2009; Gray, 1973). For example, resources were found to be less important for the diffusion of moral policies than they were for administrative or technical innovations (Boushey, $20 \mathrm{I} \circ$ ), and motivational factors were found to be more important in the adoption process of a social policy (Gray, I973). Because the realization of CYFs are of direct societal importance, and because municipalities received financial compensation for the realization of CYFs we do expect motivations to be more important than both resources and obstacles. Our Motivation Hypothesis thus reads: motivational factors have stronger effects than resource and obstacle variables. In the next section we derive concrete hypotheses from rational choice theory (Berry \& Berry, 2007) concerning Mohr's ( I 969) motivations, obstacles and resources that might affect how quickly municipalities are to realize CYFs.

\subsection{Motivation}

Municipal governments may adopt and implement innovations because they have a strong motivation to do this (Berry \& Berry, 2007; Mohr, i 969). The motivation to come up with new policies may have different origins. The first reason is that when there are severe local problems, local governments might feel the urge to come up with solutions to these existing problems (Karch, 2006; Sapat, 2004). Second, motivations can be ideology driven. Ideological preferences, and ideological differences between politicians and political parties can make it difficult to arrive at a common solution for local problems (Daley \& Garand, 2005; Makse \& Volden, 20 I I). On the other hand, when ideological preferences of politicians are in favor of change regarding a certain policy, implementation becomes much more likely (McNeal, Tolbert, Mossberger, \& Dotterweich, 2003). Problem severity and ideology as motivations for innovation both refer to what is known in the literature as policy-seeking motivations (for example, Budge \& Laver, I 986; Robertson, I 976; Ware, I 992). In addition to these two possible policy-seeking motivations, there might also be vote-seeking motivations, which come from the desire of politicians and political parties to attract votes in order to win elections (Budge \& Laver, I 986; Robertson, I 976; Ware, I 992). Our general hypothesis concerning municipalities' motivation to realize a CYF is that they will do this sooner when they feel stronger motivated. We derive one hypothesis concerning the need for the policy, we derive two hypotheses concerning ideological preferences, and we derive one hypothesis concerning vote-seeking motivations.

It has been argued that decisions to opt for specific policy solutions are dependent on the perceived severity of the problems (Berry \& Berry, 2007; Karch, 2007a). The severity of a problem can be a motivation to innovate since it can clarify the need for the policy, or because societal groups demand for adequate policy solutions (Berry \& Berry, 2007, p. 235). Sapat $(2004)$ found, for example, that state agencies were likely to adopt innovations to 
confront problems that were created by hazardous waste contamination. Karch (2006) hypothesized that the diffusion of individual development accounts (IDAs) increased with the (problematic) number of births to teenage mothers in a state. Thus, we assume that when municipalities face more problems against which the aims of the policy are targeted, they will try to mitigate these problems earlier than when they experience less problematic situations. Problem Severity Hypothesis: Municipalities will realize a CYF earlier when they experience more youth related problems.

We have now derived one motivational hypothesis reflecting the need for CYF adoption. Next we derive two hypotheses that reflect governments' ideology. First, it has often been argued that the political composition of governments influences the likelihood of innovation adoption (Berry \& Berry, I 990; Boehmke \& Witmer, 2004; Sugiyama, 2008). When a new policy reflects the preferences of the main ideology in a municipality it is more likely that it gets implemented. In the Netherlands, the Christian Parties, the Christian Democrats (CDA), the Reformed Protestant Party (SGP), and the Christian Union (CU) are traditionally associated with a strong preference for family policies. Government Ideology Hypothesis: Municipalities will realize a CYF earlier when they have more Christian parties in their council.

Second, it has been argued that vertical or top-down pressure is important in the innovation process, because it can influence both the speed of the diffusion process (Berry \& Berry, 2007) and the substance of the innovation (Karch, 2006). The willingness to obey to a central mandate is derived from ideological differences between the national government and local governments (Jans et al., n.d.). Political Alignment Hypothesis: Municipalities will realize a CYF earlier when their party preferences are more aligned to those of the national government.

At last, a vote-seeking motivation, that has often been hypothesized to affect governments' innovation decisions is electoral competition (McNeal et al., 2003). Local politicians who are facing closely contested elections are assumed to embrace new programs to try to broaden their electorate (Berry \& Berry, 2007; García-Sánchez, Rodríguez-Domínguez, \& Gallego-Álvarez, 20I I). We argue that municipalities with more party competition are stronger motivated to come up with new policies. Electoral Competition Hypothesis: Municipalities will realize a CYF earlier when they have higher levels of party competition.

\subsection{Obstacles}

Mohr ( I 969) also considers obstacles to be of importance in the adoption and implementation of new polices (see also, Berry \& Berry, 2007). Our general hypothesis about the obstacles to innovate is that municipalities that face more obstacles will be later adopters than the ones having fewer obstacles. We derive one hypothesis from this general hypothesis. 
An important obstacle to innovation is the disagreement between politicians or policymakers as to whether there is a problem for which governmental action is needed (Karch, 2007a). The disagreement on what measures need to be taken is also assumed to be higher among more fragmented governments (Allen, 2005; Haider-Markel \& Meier, I 996). For example, Brooks (2005) argued that the chances of winning majority support in the legislative process declines when political powers are shared broadly across distinct political parties. Party Fragmentation Hypothesis: Municipalities will realize a CYF later when local political fragmentation is stronger.

\subsection{Resources}

In addition to motivations and obstacles, Mohr (1 969) recognizes resources as a third factor that is important for innovation. A municipalities' command over financial, human and social resources is argued to be important for the diffusion of innovations (Berry \& Berry, 2007). Financial resources refer to the amount of revenues a municipality receives, human resources refer to the quantity and quality of available staff, and social resources refer to a municipalities' access to relevant networks. Our general hypothesis concerning the influence of resources is that municipalities with more resources will adopt the innovation sooner than municipalities with fewer resources, even if the municipalities were given money from the central government to realize the CYFs. We derive four specific hypotheses from this general hypothesis.

The first municipal resource is organizational capacity (Ahn, 20 I I ; Walker, I 969). Organizations with more command over financial and human capital are generally more inclined to adopt innovations than less resourceful organizations are. Organizational Capacity Hypothesis: Municipalities will realize a CYF earlier when they have greater organizational capacity.

Second, political attention is considered an important resource, because policy priorities of governments determine to a large extent the amount of available resources for the implementation of new programs or policies (Jacoby \& Schneider, 200I). The priorities of governments can become visible by the decision to formalize these priorities by means of area specific political portfolio's (Jans et al., n.d.). Appointment of an alderman 'Youth' was also one of the recommendations of the aforementioned advisory committee 'Operation Young'. We assume that if the main governing body of a municipality, which is the Board of Mayor and Aldermen (hereafter referred to as BMA), has a mayor or aldermen with 'Youth' in its portfolio, it has possibilities to allocate more personal and financial resources for the CYF realization. Youth Portfolio Hypothesis: Municipalities will realize a CYF earlier when their BMA has a 'Youth' specific portfolio.

Third, it has been shown that governments do not make decisions in isolation. That is why horizontal networks are considered to be an important resource (Balla, $200 \mathrm{I}$; McNeal 
et al., 2003). Professional networks are important for politicians and policy makers to exchange information and to acquire relevant information (Balla, 200 I; McNeal et al., 2003; Sugiyama, 2008). Networks create a setting where policy makers can discuss the latest developments, standards, and many municipal level policy innovations. We expect municipalities with leadership in a professional network to be better informed of the latest developments, and thus more likely to conform to the latest developments. Professional Network Hypothesis: Municipalities will realize a CYF earlier when they have leadership in a professional network.

Fourth, other horizontal networks can be considered a resource. In the literature, an often-used proxy measure for inter-governmental contact leading to the spread of policies is geographic proximity. One of the first scholars to conclude that states adopted new programmes more often when other similar states had already adopted them was Walker ( I 969). Later, much support has been found for the claim that policies diffuse across neighbouring governments (for example, Berry \& Berry, I 990; Volden, 2006). However, it is not so clear why proximity should lead a policy to diffuse (Beck, Gleditsch, \& Beardsley, 2006; Karch, 2007b). Therefore we use a more direct conceptualization. To do so, we take into account the places where policy-makers exchange or acquire their information (Füglister, 20 I I). Policy Network Hypothesis: Municipalities will realize a CYF earlier when there are more municipalities in the same policy network that already have realized a CYF.

\section{Data and method}

Information about the years in which municipalities realized a CYF were collected from the annual reports about the broad goal-oriented grants for the CYFs (Houwer, De Jong, Richt, \& Atalay, 2008-20 I I). The Minister of Y\&F announced his plans in their policy program in September 2007 (J\&G, 2007), and in a letter to all municipalities in January 2008 it was explained what the specific role was for the municipalities in the CYF implementation (J\&G, 2008). For all municipalities the first possible year of realization was 2008 , the last realization took place in $20 \mathrm{I} 2$. The potential number of adopting municipalities was 4 I 5 in 20 I 2. Because of missing values we run our analysis on 38 I municipalities (9 г \%). In terms of size, our sample is representative for the total population of Dutch municipalities. ${ }^{3}$

\subsection{Motivational variables}

The variable PROBLEM SEVERITY is measured by a scale based on the 'Kinderen in Tel' Data book (Steketee, Mak, \& Tierolf, 2009), which is the Dutch equivalent of the American 'Kids Count'. The scale we used included measures for child mortality, youth criminality, youth unemployment, youth care, children in disadvantaged neighborhoods, children in 
poverty, child abuse, children with learning disabilities and school absenteeism, and teenage mothers. We created a scale based on the average of the individual items. ${ }^{4}$

To measure GOVERNMENT IDEOLOGY, we estimate the percentage of politicians in the BMA from the Christian Parties, the Christian Democrats (CDA), the Reformed Protestant Party (SGP) and the Christian Union (CU). The variable was constructed using data from the Dutch Association of Municipalities (VNG). ${ }^{5}$ This variable ranges between $\circ$ and ז००.

To measure the similarity in political composition between the national government and local governments we constructed the variable POLITICAL ALIGNMENT. This variable measures the proportion of political parties in a municipal council that are represented in the national government's coalition. The variable ranges between $\odot \%$ and $\mathrm{i} \circ \%$. As the score on the variable increases, the greater the local-national party alignment is. The variable is timevarying and was constructed using data from local and national elections in 2006 and $2010 .^{6}$ Data were obtained from Kiesraad (20 I I).

The quantity of ELECTORAL COMPETION in a municipality is measured by the amount of electoral volatility between two election periods. The variable is calculated using the method proposed by Pedersen ( I 979). We calculated the volatility for two election periods. For 2008 and 2009 we calculated the volatility for the local elections of 2002 and 2006 . For the years between 2010 and 2012 we calculated the electoral volatility for the elections of 2006 and $20 \mathrm{IO}$. A higher score means that a municipal council experiences more political competition. Data ranges between I.67 and 7r.43, and is collected from the website nlverkiezingen.com (own calculations). ${ }^{7}$

\subsection{Obstacle variable}

We measure the amount of PARTY FRAGMENTATION in a municipality with the Laakso-Taagepera index (1979). This index reflects the effective number of political parties in a municipal council by taking into account their relative size. A higher score means a more fragmented municipal council. We constructed this time-varying variable by using data from the 2006 and $20 \mathrm{r} 0$ local elections. This covers the full period between 2008 and 20 I 2. Data ranges between 0.16 and 10.07, and comes from the Electoral Council (Kiesraad, 20062010).

\subsection{Resources variables}

The measurement of ORGANIZATIONAL CAPACITY is based on the standardized log transformed scores of the fulltime-equivalent (fte) municipal staff per roo० inhabitants (BZK, 2007-20II), and the amount of money municipalities received from the municipal 
fund per roo० inhabitants (BZK, 2008-20 I I). We combined these two variables into one reliable scale for the years 2008 to 20 I 2 . For both variables only the scores of 2008 are used, because the scores were highly comparable across all five years (municipal fund correlations $=\mathrm{I} .000$ for all years, the fte correlations are all $>0,893)$. A factor analysis and a subsequent reliability test indicated that one organizational capacity scale could be constructed $(\alpha=$ 0.8 I 4 and eigenvalue = I.697). The variable ranges between -5.03 and I I. I 9 .

We measure BMA PORTFOLIO with $\circ$ if a municipality had no mayor or alderman who was responsible for the 'Youth' portfolio or the 'Health care and municipal health service' portfolio, and with I if it had a mayor or alderman with such responsibilities formalized in a portfolio. Data comes from the Dutch Association of Municipalities (VNG). ${ }^{8}$

We measured leadership in a PROFESSIONAL NETWORK with a dummy variable taking the value of $\circ$ if a municipality had no representation in the leadership of a provincial VNG department, and I if it had leadership. The boards of the provincial VNG department are usually composed of mayors and aldermen. Occasionally also local councilors are in the board. These provincial departments have the task to provide municipalities with information about issues that arise in the province, and they also represent the interests of the municipalities. Data is self-collected from the annual reports of the provincial departments.

Table 1. Descriptive Statistics ( $N=1147$, N Clusters 381).

\begin{tabular}{|c|c|c|c|c|c|}
\hline & Time varying & Mean & sd. & Min. & Max. \\
\hline \multicolumn{6}{|l|}{ Dependent variable } \\
\hline CJG ADOPTION & yes & 0.33 & 0.47 & $\circ$ & I \\
\hline \multicolumn{6}{|l|}{ Motivational variables } \\
\hline PROBLEM SEVERITY & no & -0.05 & 0.56 & -1.36 & 2.76 \\
\hline GOVERNMENT IDEOLOGY & yes & 30.54 & 20.73 & $\circ$ & I 00 \\
\hline POLITICAL ALIGNMENT & yes & 58.38 & $23 \cdot 34$ & $\circ$ & I $० 0$ \\
\hline ELECTORAL COMPETITION & yes & I 8.9 I & IO. I I & I. 67 & 71.43 \\
\hline \multicolumn{6}{|l|}{ Obstacle variable } \\
\hline PARTY FRAGMENTATION & yes & 5.06 & $\mathrm{I} .2 \mathrm{I}$ & .16 & 10.07 \\
\hline \multicolumn{6}{|l|}{ Resources variables } \\
\hline ORGANIZATIONAL CAPACITY & no & -0.12 & I. 75 & -5.03 & II.IS \\
\hline YOUTH PORTFOLIO & yes & 0.75 & 0.44 & $\circ$ & I \\
\hline PROFESSIONAL NETWORK & yes & 0.29 & 0.45 & $\circ$ & I \\
\hline ADOPTION POLICY NETWORK & yes & 39.26 & 32.22 & $\circ$ & 100 \\
\hline \multicolumn{6}{|l|}{ Duration } \\
\hline YEARS & yes & 2.18 & 1.03 & I & 5 \\
\hline
\end{tabular}

To measure the POLICY NETWORK we constructed a variable measuring the cumulative number of municipalities in a policy network that already adopted a CYF. Municipalities all have their own Municipal Health Services (In Dutch: Gemeentelijke Gezondheidsdienst, hereafter referred to as MHS), which are all accommodated in larger organizational networks, the so-called MHS-regions. The network classification is based on 
information from the National Institute for Public Health and the Environment (In Dutch: Rijksinstituut voor Volksgezondheid en Milieu (RIVM)) (RIVM, 2008). This variable is time-varying and ranges between $\circ$ and $\mathrm{s} \circ 0$ percent.

Each municipality potentially contributes multiple records, one for each year, to our data set. Having repeated measures can lead to problems of temporal dependence. Therefore, we include $\mathrm{t}$ (time), $\mathrm{t}^{2}$ and $\mathrm{t}^{3}$ (Carter \& Signorino, $\left.20 \mathrm{ro}\right) .{ }^{9} \mathrm{We}$ have found multicollinearity to be a problem, and therefore demeaned $t$, and used t/ $\mathrm{s} \circ 0$, and its square. For reasons of interpretation we standardized (z-scores) all interval variables. Table I presents the means, standard deviations, and range on the original scales of all variables used in our analyses.

We test our hypotheses by using Event History Analysis (EHA), which estimates the probability that a municipality will realize a CYF in a given year, given that it has not already done so in previous years (Berry \& Berry, ı990; Singer \& Willett, 2003). We constructed a municipality-year dataset containing a record for each municipality for each year it is 'at risk' of adoption. For each municipality, the dependent variable is coded zero, except for the year in which it adopts a CYF. For the year of adoption, the dependent variable takes on the value of one, and consequently there are no further records for municipalities for the years after they had realized a CYF. The risk set therefore decreases in size as the years pass. Parameters of our models are estimated by using standard logistic regression analysis.

\section{Analyses and results}

In this section we answer our two research questions. We will now answer the first question: To what extent do differences exist among Dutch municipalities in the timing of the realization of a CYF. Table 2 shows the major events and timelines that were discussed in the introduction, and that are crucial in the process of CYF realization by municipalities. The cumulative distribution of adoptions demonstrates that it took over two years for the adoption rate to increase firmly. The increase in adoptions was strongest in the years $20 \mathrm{I} \circ$ and $20 \mathrm{I}$. This is not very surprising when we consider the deadline set by the Ministry of Y\&F by the end of the year $20 \mathrm{I}$ I. In $20 \mathrm{I} 2$ there was only one municipality realizing a CYF. By that time all municipalities in the Netherlands had realized a CYF. Of all municipalities, in 2008 I $3 \%$ had a CYF, in $200926 \%$, in $201062 \%$, in 20 I I $99 \%$, and in 20 I 2 1 $00 \%$. On the basis of table 2 we conclude with regard to our first question that there was considerable variation among municipalities in the timing of CYF-adoptions. These findings imply that when the national government sets a mandate, this does not mean that local governments will instantly react, or that they will all react at the same time, or that all local governments will meet the deadlines set. It is clear that municipalities used discretion when it comes to the timeframe of realization. The shown differences in the timing of realization make clear that studying these types of innovations is substantially more interesting than previously 
suggested (compare, Berry \& Berry, 2007; Karch, 2006). Of course, vertical pressures by the national government played an important role in the implementation of CYFs, as we have seen from the strong increase in adoptions in $20 \mathrm{I} \circ$ and $20 \mathrm{I}$ I when the deadline approached. Thus, in understanding processes of innovations there is also clearly a need to understand processes of mandated innovations.

Table 2. Major events and timelines of the adoption of CYFs.

\begin{tabular}{|c|c|c|c|c|c|}
\hline \multirow[t]{2}{*}{ Event } & \multirow[t]{2}{*}{ Timeline } & \multirow[t]{2}{*}{ Year } & \multirow[t]{2}{*}{$\mathrm{N}$ mun. } & \multicolumn{2}{|c|}{ CYF-adoption } \\
\hline & & & & $\%$ of mun. & $\%$ change \\
\hline National elections & 22 November 2006 & $\circ$ & - & - & - \\
\hline $\begin{array}{l}\text { Inauguration cabinet Balkenende IV (2006- } \\
20 \mathrm{I} 0 \text { ) and announcement new Ministry for } \\
\text { Youth and Family }\end{array}$ & 22 February 2007 & $\circ$ & - & - & - \\
\hline Policy program Ministry for Youth and Family & September 2007 & $\circ$ & - & - & - \\
\hline $\begin{array}{l}\text { Letter from Ministry for Youth and Family to } \\
\text { municipalities presented to the parliament }\end{array}$ & I 6 November 2007 & $\circ$ & - & - & - \\
\hline \multirow[t]{3}{*}{$\begin{array}{l}\text { Letter from Ministry for Youth and Family to } \\
\text { municipalities }\end{array}$} & January 2008 & $\circ$ & - & - & - \\
\hline & December 2008 & I & 53 & I 3.0 & $\circ$ \\
\hline & December 2009 & 2 & 53 & 26.0 & I 3.0 \\
\hline National elections & 9 June 2010 & - & - & - & - \\
\hline \multirow{4}{*}{$\begin{array}{l}\text { Inauguration cabinet Rutte I (20 I 0-20 I } 2 \text { ) and } \\
\text { abolishment Ministry for Youth and Family }\end{array}$} & October $20 \mathrm{I} \circ$ & - & - & - & - \\
\hline & December 20 I० & 3 & I 46 & 6 I.9 & 35.9 \\
\hline & December 20 I I & 4 & I 54 & 99.8 & 37.8 \\
\hline & December 20 I 2 & 5 & I & I 00.0 & 0.2 \\
\hline
\end{tabular}

Now we will answer our second research question: how can we explain differences in the timing of the realization of CYFs among Dutch municipalities? Our dependent variable is a dichotomous measure of whether a municipality realizes a CYF in a particular year, and therefore we employ logistic regression analysis. Parameters are estimated using Stata/IC I 3. I. In table 3 we present the estimated coefficients, robust standard errors, and the Akaike Information Criterion (AIC) value as measurement for the model fit. Regression diagnostics were performed and revealed only minor problems that had dealings with influential cases. We removed five influential municipalities from our analyses. ${ }^{\text {Io }}$

In model I we examine the association between CYF-realization and the motivational factors, in model 2 we do this for the obstacles, and in model 3 we test for the influence of resources. Model 4 tests for the influence of all motivation, obstacles, and resources variables. In a final analytical step we compare the effect sizes of the latent constructs motivations, obstacles and resources to determine what was the most important for the timing of the realization of CYFs. To compare the relative effects of motivational variables to those of obstacles and resources, we compared the effect sizes of the different blocks of vari- 
ables by calculating the sheaf-coefficient (Heise, 1972), implemented by the sheafcoefpackage in Stata I 3. I (Buis, n.d., 20 I o).

Model I in table 3 shows the estimates of the effects of the variables that capture a municipalities' motivation to innovate. We expected that stronger motivated municipalities would realize a CYF earlier. The coefficient of the problem severity variable shows up in the expected positive direction, and is statistically different from zero $(p=0.000)$. This indicates that in each year, municipalities experiencing more youth related problems have a greater likelihood of CYF realization. A one-unit (one sd.) increase in problem severity is associated with an approximate $44 \%\left(\mathrm{I} \circ \circ^{*}\left(\left(\mathrm{e}^{\wedge} \circ .366\right)-\mathrm{I}\right)=44.2 \%\right)$ increase in the odds of CYF realization. The coefficient of the political alignment variable is also positive, in the expected direction, and statistically different from zero $(p=0.003)$. This means that in each year, municipalities that are politically more aligned with national government have a greater likelihood of realizing a CYF. A one-unit (one sd.) increase in political alignment is approximately associated with a 3 I \% increase in the odds of CYF-realization. This is a provisional confirmation of our problem severity hypothesis, and our political alignment hypothesis. The coefficients of the government ideology variable and the electoral competition variable do not attain conventional levels of statistical significance, and appear to be unrelated to the realization of CYFs. The overall implication of these findings is that in general, hypotheses regarding motivation were only partly confirmed.

Model 2 in table 3 shows the result of the variable reflecting the obstacles to CYFrealization. We assumed municipalities with fewer obstacles to be earlier adopters of a CYF. The coefficient of the party fragmentation variable does not appear to be statistically different from zero. This means that the party fragmentation hypothesis is for the moment rejected.

Model 3 in table 3 shows the coefficients for the factors reflecting resources for CYFrealization. We hypothesized that municipalities that were more resourceful would be earlier realizers of a CYF. The organizational capacity variable $(p=0.000)$ shows that in each year municipalities that have a larger organizational capacity have a greater likelihood of CYF realization. A one-unit (one sd.) increase in organizational performance is associated with a $69 \%$ increase in the odds of CYF-realization. The coefficient of the policy network is also positive and statistically different from zero $(p=0.000)$. This implies that in each year municipalities that have more municipalities in the same policy network that have already realized a CYF are more likely to realize a CYF earlier themselves. The effect of the policy network variable is very large; each additional unit (one sd.) increase on this variable is associated with a rise of $597 \%$ in the odds of CYF-realization. This implies an initial confirmation of the organizational capacity hypothesis and of the policy network hypothesis. The youth portfolio and the professional network variables fail to attain the conventional levels of statistical significance and thus appear to be unrelated to the timing of the realization of CYFs. These findings also mean that the general resources hypothesis is only partially confirmed. 
Table 3. Logistic regression coefficients explaining the timing of the adoption of a CYF $(N=1130$, N Clusters 376).

\begin{tabular}{|c|c|c|c|c|}
\hline & $\begin{array}{c}\text { Model I } \\
\text { b/se }\end{array}$ & $\begin{array}{c}\text { Model } 2 \\
\text { b/se }\end{array}$ & $\begin{array}{c}\text { Model } 3 \\
\text { b/se }\end{array}$ & $\begin{array}{c}\text { Model } 4 \\
\mathrm{~b} / \mathrm{se}\end{array}$ \\
\hline \multicolumn{5}{|l|}{ Motivational variables } \\
\hline PROBLEM SEVERITY & $\begin{array}{l}0.37^{* *} \\
(0.09)\end{array}$ & & & $\begin{array}{c}0.05 \\
(0.13)\end{array}$ \\
\hline GOVERNMENT IDEOLOGY & $\begin{array}{l}-0.05 \\
(0.09)\end{array}$ & & & $\begin{array}{l}-0.10 \\
(0.1 \mathrm{I})\end{array}$ \\
\hline POLITICAL ALIGNMENT & $\begin{array}{l}0.27^{* *} \\
(0.09)\end{array}$ & & & $\begin{array}{l}0.3^{* *} \\
(0.10)\end{array}$ \\
\hline ELECTORAL COMPETITION & $\begin{array}{c}0.13 \\
(0.08)\end{array}$ & & & $\begin{array}{l}0.12 \\
(0.09)\end{array}$ \\
\hline \multicolumn{5}{|l|}{ Obstacle variable } \\
\hline PARTY FRAGMENTATION & & $\begin{array}{c}0.10 \\
(0.08)\end{array}$ & & $\begin{array}{c}0.08 \\
(0.09)\end{array}$ \\
\hline \multicolumn{5}{|l|}{ Resources variables } \\
\hline ORGANIZATIONAL CAPACITY & & & $\begin{array}{l}0.63^{* *} \\
(0.12)\end{array}$ & $\begin{array}{l}0.53^{* *} \\
(0.15)\end{array}$ \\
\hline YOUTH PORTFOLIO & & & $\begin{array}{l}-0.20 \\
(0.2 \mathrm{I})\end{array}$ & $\begin{array}{l}-0.22 \\
(0.22)\end{array}$ \\
\hline PROFESSIONAL NETWORK & & & $\begin{array}{c}0.1 \mathrm{I} \\
(0.20)\end{array}$ & $\begin{array}{c}0.09 \\
(0.20)\end{array}$ \\
\hline ADOPTION POLICY NETWORK & & & $\begin{array}{l}\text { I. } 94^{* *} \\
(0.22)\end{array}$ & $\begin{array}{l}\text { I. } 99^{* *} \\
(0.23)\end{array}$ \\
\hline Constant & $\begin{array}{c}-\mathrm{I} .77^{* *} \\
(0.14) \\
\end{array}$ & $\begin{array}{c}-1.70^{* *} \\
(0.13) \\
\end{array}$ & $\begin{array}{c}-1.27^{* *} \\
(0.23) \\
\end{array}$ & $\begin{array}{c}-1.28^{* *} \\
(0.23) \\
\end{array}$ \\
\hline $\mathrm{N}$ & II 30 & 1130 & 1130 & 1130 \\
\hline Df & 6.0 & 3.0 & 6.0 & II.O \\
\hline Logl & $-46 \mathrm{I} \cdot 5$ & -479.6 & -4 I 2.1 & -405.9 \\
\hline AIC & 937.0 & 967.3 & 838.2 & 835.7 \\
\hline
\end{tabular}

** $\mathrm{p}<0.0 \mathrm{I},{ }^{*} \mathrm{p}<0.05,+\mathrm{p}<0 . \mathrm{I} 0$ : two-tailed.

Note: To account for repeated measures, all models are estimated with robust standard errors clustered on individual municipalities. Estimated coefficients with standard errors in parentheses beneath.

The results of model 4, where we tested simultaneously for the effects of motivation, obstacles, and resources did slightly change the outcomes and results that we described earlier. For the motivational variables, now only the political alignment variable seems to be related to the timing of CYF-realization $(p=0.002)$. A one-unit (one sd.) increase in political alignment is now associated with an approximate $36 \%$ increase in odds of CYF-realization, instead of 3 I $\%$ in model $\mathrm{r}$. We can now definitely confirm the political alignment hypothesis. The other three hypotheses, problem severity, government ideology, and electoral competition are now definitely rejected. The general motivation hypothesis is hereby only marginally confirmed. Again, the obstacle variable failed to attain conventional levels of statistical significance. The party fragmentation hypothesis, and the general obstacles hy- 
pothesis are now definitely rejected. For the resources variables, both the coefficients of the organizational variable $(p=0.00 \mathrm{I})$, and the policy network variable $(p=0.000)$ are again positive and statistically different from zero. Compared to the results in model 3 , the results of the resources variables did not change for the organizational capacity variable, but they did change slightly for the policy network variable. A one unit (one sd.) increase is now associated with a $632 \%$ increase in odds of CYF-realization, compared to $597 \%$ in model 3 . Therefore, the youth portfolio hypothesis, and the professional network hypothesis are now definitely rejected. The organizational hypothesis and the policy network hypothesis are hereby confirmed, and in general, the hypotheses regarding resources were only partially confirmed.

To test the motivation hypothesis, we compare the effect sizes of the latent constructs motivations, obstacles and resources. In doing so, we can determine which factor was the most important for explaining differences in the timing of the realization of CYFs. We calculated the sheaf-coefficient (Heise, I972), by using the sheafcoef-package in Stata I3.I(Buis, n.d., 20I0). The coefficient of the motivational variables block is $0.3 \mathrm{I} 9$ $(p=0.00 \mathrm{I})$, that of the resources block is $2.022(\mathrm{p}=0.000)$, and that of the obstacles block is 0.076 ( $p=0.4$ I I ). This means that obstacles played no role, and that resources were considerably more important than motivations in the adoption process of CYFs. This means we have to reject our motivation hypothesis.

\section{Conclusion and Discussion}

The decentralization of responsibilities to implement policies has increased over the last decades in several countries around the world. In the Netherlands, often characterized as a decentralized unitary state (Denters \& Rose, 2005, p. I I), municipalities increasingly function as an extension of national government via co-governance arrangements (Denters \& Klok, 2005). Meaning that municipalities are held responsible for the implementation of policies and laws that are nationally determined. In these co-governance structures, the question if local circumstances allow for differences in the execution and implementation of policies is very important. Investigating determinants of innovation for mandated policies is thus required. To determine whether the great promise of decentralization -local priorities and local circumstances determine differences in innovativeness, is taking place it is necessary to examine local level discretion within the limits of what is to be implemented. In this paper we answer two questions ( I) To what extent do differences exist among Dutch municipalities in the timing of the realization of a CYF? and (2) How can we explain differences in the timing of the realization of CYFs among Dutch municipalities?

We found considerable differences in the speed of adoptions of CYFs. More than a quarter of all municipalities realized a CYF already in 2009, and more than 60 percent of all municipalities realized a CYF in $20 \mathrm{I} \circ$, which was a year before the deadline set by the na- 
tional government. This is a totally different picture than was shown, for example, with the adoption of a mandated administrative e-government innovation, where the deadline had to be postponed because a great lack of municipal compliance (Jans et al., n.d.). Although the overall rather timely realization of CYFs we found clear differences in timing between municipalities, which needed explanation.

To investigate the determinants for variations in timing between municipalities we applied a rational choice model emphasizing the motivations, obstacles, and resources for innovation (Berry \& Berry, 2007; Mohr, I 969). We found that when municipalities were politically more aligned to the national governments' coalition that they realized a CYF earlier. This indicates that municipalities are more responsive to policy initiatives that are initiated by political parties of their own signature. Despite the fact that it is widely acknowledged that top-down pressures (Berry \& Berry, 2007; Karch, 2006), and ideological preferences (McNeal et al., 2003), can be important in the innovation process, political alignment is a rather underexposed factor in innovation research (Jans et al., n.d.). We also found that differences in organizational capacity were responsible for differences in the speed of adoptions. This is in line with other research (Ahn, 20 I I; Walker, I 969), but in our case it is quite striking that organizational capacity - which we measured by taking into account financial resources as well as human resources - still played such an important role in explaining differences in timing. Despite the financial compensation municipalities received by means of a Broad Goal-oriented Grant Youth and Family, more resourceful organizations still were quicker with realization of a CYF. A possible explanation for this might be that existing organizational structures are better developed in larger organizations. Maybe due to their past experiences or past performance in youth care (compare, Jans et al., n.d.), or because of the institutionalization of youth policies (compare, Tolbert, Mossberger, $\& \mathrm{McNeal}$, 2008). Future research into the adoption of social policies should try to take into account these types of measures for resources. The last significant finding was that policy networks played a role. When more municipalities in the same policy network adopted a CYF, chances for municipalities' own adoption increased. This effect of inter-governmental contact as driver for the spread of innovations has been found on numerous occasions (for example, Berry \& Berry, ı 990; Füglister, 20 I I; Volden, 2006). We have also taken into account the influence of professional networks, but these were not significant predictors of adoption. Because policy networks were, this might indicate that youth policy is in stronger connection with administrative networks than with political networks.

In contrast with what was argued in other innovation studies (Allen, 2005; Brooks, 2005; Haider-Markel \& Meier, I 996), party fragmentation was not a significant obstacle for CYF realization. However, these were all studies investigating voluntary innovations. In another study of a mandated innovation, party fragmentation was also found to have no influence on the timing of adoption (Jans et al., n.d.). Furthermore, although appointing an alderman 'Youth' was one of the recommendations of the advisory committee 'Operation Young' it had 
no significant impact on the timing of CYF realization, indicating either a possible lack of institutionalization (compare, Tolbert et al., 2008), or a possible lack of policy entrepreneurship by the individual aldermen (compare, Mintrom \& Norman, 2009). Future research should try to disentangle under what circumstances - that is, for different types of policies in either mandated or voluntary circumstances - policy entrepreneurs can be critical for the implementation of new policies.

To reinforce the theoretical arguments to make, we investigated the combined effects for the three Mohr ( I 969) factors. Although motivations, obstacles, and resources are often used to derive hypotheses about differences in innovativeness (for example, Berry \& Berry, 2007), as far as we know it is quite unique to compare the effects sizes for these three latent constructs. We found that obstacles were not important, and that resources were more important than motivations in the realization of CYFs. This is opposite to what we expected, and to what other researchers suggested (Jans et al., n.d.). We expected that motivations were more important than resources because social policies presumably are politically more pertinent, because they directly influence citizens' wellbeing, and are therefore close to the core interest of local politicians. It is rather surprising that resources were important whilst financial barriers for the realization of CYFs were taken away by the national government via the aforementioned grant. A possible explanation for the weak effect of motivations is that governments are not very well equipped to analyze local problems and to analyze the coherence between local problems (Denters, van Heffen, \& de Jong, i 999). With our measure of problem severity we assume that politicians inform themselves about local problems and needs, but we lack the information if local politicians actually use this information to inform local policymaking. Future research could try to find under what circumstances local politicians inform themselves about local problems and needs, and what effect this has on policy outcomes. Another reason might be that the effects of government ideology and electoral competition might not become visible when mandated innovations are adopted under a certain amount of time pressure. More time to realize an innovation self-evidently allows for more variation in timing. This might leave room for stronger motivated and more conscious choices to adopt either earlier or later, based on motivations such as political ideology, or the degree of electoral competition. Investigating mandated policies with different time frames could make progress.

We have aimed to come up with a testable hypothesis for the realization of a social policy, which stated that ideological and political motivations were more important than resources. For this hypothesis we found no evidence in our study. Replication of this hypothesis in other settings and in different countries can help to determine under what conditions governments' innovation decisions are more susceptible to motivations than to resources (compare, Damanpour \& Schneider, 2009; Gray, I 973). This is important, because in certain instances more local innovation in policies is expected, and wished for, than in other circumstances. Especially when decentralization decisions are accompanied with 
CHAPTER THREE

the notion that local governments are well capable of developing policies based on local priorities, it is important to investigate if motivations indeed play a role. 


\section{REFERENCES}

Ahn, M. J. (20 I I). Adoption of Applications in U.S. Municipalities: The Role of Political Environment, Bureaucratic Structure, and the Nature of Applications. The American Review of Public Administration, 4I (4), 428-452. doi: I O. I I $77 / 02750740$ I0377654

Allard, S. W. (2004). Competitive pressures and the emergence of mothers' aid programs in the United States. Policy Studies Journal, $32(4), 52$ I-544.

Allen, M. D. (2005). Laying Down the Law? Interest Group Influence on State Adoption of Animal Cruelty Felony Laws. Policy Studies Journal, 33(3), 443-457. doi: I o. I I I I/j. I 54 I-0072.2005.00 I 24.X

AZ. (2007). Working together living together, Government program Cabinet Balkenende IV 2007-20 I I [In Dutch: Samen werken samen leven, beleidsprogramma Kabinet Balkenende IV 2007-20 I I ]. The Hague, The Netherlands: Ministerie van Algemene Zaken.

Balla, S. J. (200 I). Interstate Professional Associations and the Diffusion of Policy Innovations. American Politics Research, 29(3), 22 I-245. doi: I 0. I I 77/1 532673 X0 I 29300 I

Beck, N., Gleditsch, K. S., \& Beardsley, K. (2006). Space is more than geography: Using spatial econometrics in the study of political economy. International Studies Quarterly, 5 O( I), 27-44.

Berry, F. S., \& Berry, W. D. ( I 990). State lottery adoptions as policy innovations: An event history analysis. American Political Science Review, 84(2), 395-4 I 5.

Berry, F. S., \& Berry, W. D. (2007). Innovation and diffusion models in policy research. In P. A. Sabatier (Ed.), Theories of the Policy Process (second., pp. 223-260). Boulder, CO: Westview Press.

Boehmke, F. J., \& Witmer, R. (2004). Disentangling diffusion: The effects of social learning and economic competition on State policy innovation and expansion. Political Research Quarterly, 57 (I), 39-5 I. doi: I O. I I 77/106591 290405700104

Boushey, G. (20 1 ०). Policy diffusion dynamics in America. Cambridge University Press.

Boyne, G. A., Gould-Williams, J. S., Law, J., \& Walker, R. M. (2005). Explaining the adoption of innovation: An empirical analysis of public management reform. Environment and Planning C: Government E Policy, 23(3), 4 I 9435 .

Brooks, S. M. (2005). Interdependent and domestic foundations of policy change: The diffusion of pension privatization around the world. International Studies Quarterly, 49(2), 273-294.

Budge, I., \& Laver, M. ( I 986). Office seeking and policy pursuit in coalition theory. Legislative Studies Quarterly, 485506.

Buis, M. L. (n.d.). Combining information from multiple variables using models for causal indicators. Working Paper.

Buis, M. L. (2० I o). SHEAFCOEF: Stata module to compute sheaf coefficients. Statistical Software Components.

BZK. (2008a). Distribution of payments from the Municipal fund [In Dutch: Verdeling van de uitkeringen uit het gemeentefonds] [Data file]. Retrieved August 2 I, 20 I 2, from http://www.rijksoverheid.nl/onderwerpen/gemeenten/documenten-enpublicaties/rapporten/20 I I/o7/28/verdeling-van-de-uitkeringen-uit-het-gemeentefonds.html

BZK. (2008b). Municipalities' budget analyses [In Dutch: Begrotingsanalyse gemeenten] [Data file]. Retrieved from http://www.rijksoverheid.nl/documenten-en-publicaties/rapporten/

Carter, D. B., \& Signorino, C. S. (20 I o). Back to the future: Modeling time dependence in binary data. Political Analysis, I 8(3), 27 I-292. doi: I ०. I $093 / \mathrm{pan} / \mathrm{mpq}$ I 3

Daley, D. M., \& Garand, J. C. (2005). Horizontal diffusion, vertical diffusion, and internal pressure in state environmental policymaking, i 989-1 998. American Politics Research, 33(5), 6 I 5-644. doi: I O. I I 77/ I $532673 \times 042734$ I 6

Damanpour, F., \& Schneider, M. (2009). Characteristics of Innovation and Innovation Adoption in Public Organizations: Assessing the Role of Managers. Journal of Public Administration Research and Theory, 19 (3), 495522. doi: I 0. I093/jopart/muno2 I

De Vries, M. S. (2000). The rise and fall of decentralization: A comparative analysis of arguments and practices in European countries. European Journal of Political Research, 38(2), I 93-224. doi: I O. I I I I/ I 475-6765.00532

Denters, B. (2005). Towards local governance? In B. Denters \& L. E. Rose (Eds.), Comparing local governance: Trends and developments (pp. 246-262). New York, NY: Palgrave Macmillan. 
Denters, B., \& Klok, P.-J. (2005). The Netherlands in search of responsiveness. In B. Denters \& L. E. Rose (Eds.), Comparing local governance: Trends and developments (pp. 65-82). New York: Palgrave Macmillan.

Denters, B., \& Rose, L. E. (2005). Comparing local governance-trends and developments. New York.

Denters, B., van Heffen, O., \& de Jong, H. M. ( I 999). Proeftuin of procrustesbed? Gemeentelijk jeugd- en veiligheidsbeleid in het kader van het grote-stedenbeleid, I 995-I 997. Bestuurskunde, 3, I 06 - I I 5.

Dijk, M., Kalsbeek, A., Prinsen, B., \& Nota, P. (2008). De lessen uit vier Europese landen. Jeugd En Co Kennis, 4(2), 3947 .

Eijck, van S. (2006). Koersen op het kind. Sturingsadvies deel I. The Hague, The Netherlands: Projectbureau Operatie Jong.

Füglister, K. (20 I I). Where does learning take place? The role of intergovernmental cooperation in policy diffusion. European Journal of Political Research, 5 I (3), 3 I 6-349. doi: I O. I I I I/j. I 475-6765.20 I I .02000.x

García-Sánchez, I.-M., Rodríguez-Domínguez, L., \& Gallego-Álvarez, I. (20 I I). The Relationship between Political Factors and the Development of E-Participatory Government. The Information Society, 27(4), 233-25 I .

Gilsing, R. (2007). Intergovernmental relations and the effectiveness of local governance the case of Dutch youth policy. International Review of Administrative Sciences, 73(I), 45-64.

Goldsmith, M. (2005). A new Intergovernmentalism? In B. Denters \& L. E. Rose (Eds.), Comparing local governance: Trends and developments (pp. 228-245). New York, NY: Palgrave Macmillan.

Goldsmith, M., \& Page, E. C. (201 o). Changing government relations in Europe : From localism to intergovernmentalism. London, England: Routledge.

Gray, V. (1973). Innovation in the states: A diffusion study. The American Political Science Review, 67(4), I I 74-I I 85.

Gray, V. ( I 994). Competition, emulation, and policy innovation. In L. C. Dodd \& C. Jillson (Eds.), New perspectives on American politics (pp. 230-248). Washington, DC: Congressional Quarterly.

Haider-Markel, D. P., \& Meier, J. ( 1996 ). The Politics of Gay and Lesbian rights: Expanding the Scope of the Conflict. The Journal of Politics, 58(2), 332-349.

Hedström, P. (2005). Dissecting the social: On the principles of analytical sociology. Cambridge University Press Cambridge.

Heise, D. R. ( 1 972). Employing nominal variables, induced variables, and block variables in path analyses. Sociological Methods \& Research, I(2), I 47-I 73 .

Houwer, J., De Jong, M., Richt, A., \& Atalay, V. (27995). Annual report broad goal-oriented grant Centers for Youth and Family [In Dutch: Jaarrapportage Brede doeluitkering Centra voor Jeugd en Gezin]. Den Haag/Amersfoort: BMC Onderzoek.

J\&G. (2007). All opportunities for all children, youth and family program 2007-20 I I [In Dutch: Alle kansen voor alle kinderen, programma voor Jeugd en Gezin 2007-20 I I ]. The Hague, The Netherlands: Programmaministerie voor Jeugd en Gezin.

J\&G. (2008). Centers for Youth and Families and the municipal directive role [In Dutch: Centra voor Jeugd en Gezin en regierol gemeente. The Hague, The Netherlands: Programmaministerie voor Jeugd en Gezin.

Jacoby, W. G., \& Schneider, S. K. (200 I). Variability in state policy priorities: An empirical analysis. Journal of Politics, $63(2), 544-568$.

Jans, W., Denters, B., Need, A., \& van Gerven, M. (n.d.). Mandatory innovation in a decentralised system: the adoption of an e-government innovation in Dutch municipalities. Acta Politica. doi: I 0. 1057 /ap.20 I 4.36

Karch, A. (2006). National intervention and the diffusion of policy innovations. American Politics Research, 34(4), 403426. doi: I 0. I I 77/ I 532673 X06288202

Karch, A. (2007a). Democratic Laboratories. Policy diffusion among the American states. Ann Arbor: The University of Michigan Press.

Karch, A. (2007b). Emerging Issues and Future Directions in State Policy Diffusion Research. State Politics E Policy Quarterly, 7(I), 54-80. doi:I 0. I I 77/1 53244000700700 I04

Kiesraad. (20 I I). Election Results. [In Dutch:Verkiezingsuitslagen] [Data file]. Retrieved from http://www.verkiezingsuitslagen.nl/Na i 9 1 8/Verkiezingsuitslagen.aspx/

Laakso, M., \& Taagepera, R. ( I 979). The "effective" number of parties: "A measure with application to West Europe." Comparative Political Studies, I 2 ( I), 3 . 
Makse, T., \& Volden, C. (2० I I). The role of policy attributes in the diffusion of innovations. The Journal of Politics, 73(01), I08-124. doi: I0.1017/So022381610000903

McNeal, R. S., Tolbert, C. J., Mossberger, K., \& Dotterweich, L. J. (2003). Innovating in digital government in the American states. Social Science Quarterly, 84(I), 52-70.

Mintrom, M., \& Norman, P. (2009). Policy entrepreneurship and policy change. Policy Studies Journal, 37(4), 649-667.

Mohr, L. B. ( I 969). Determinants of innovation in organizations. The American Political Science Review, 63 ( I), I I II 26.

Pedersen, M. N. ( I 979). The dynamics of European party systems: changing patterns of electoral volatility. European Journal of Political Research, 7( I), I-26.

Pollitt, C. (2005). Decentralization. A central concept in contemporary public management. The Oxford Handbook of Public Management, 37 I-397.

Pollitt, C., \& Bouckaert, G. (2004). Public management reform: a comparative analysis (2nd ed.). New York, NY: Oxford University Press.

RIVM. (2008). GGD-regio's 2008 - Nationale Atlas Volksgezondheid. Retrieved December i 8, 20 I 4, from http://www.zorgatlas.nl/thema-s/gebiedsindelingen-en-topografie/gebiedsindelingen/ggd-regio-s-2008/

Robertson, D. B. ( 1 976). A theory of party competition. London: John Wiley \& Sons.

Rogers, E. M. (2003). Diffusion of innovations (5th ed.). New York: Free Press.

Sapat, A. (2004). Devolution and innovation: The adoption of state environmental policy innovations by administrative agencies. Public Administration Review, 64(2), I 4 I - I 5 I. doi: I o. I I I I/j. I 540-62 I 0.2004.00356.x

Shipan, C. R., \& Volden, C. (2० I 2). Policy Diffusion: Seven Lessons for Scholars and Practitioners. Public Administration Review, 72(6), 788-796. doi: I o. I I I/j. I 540-62 I 0.20 I 2.026 I o.x.Policy

Singer, J. D., \& Willett, J. B. (2003). Applied longitudinal data analysis. New York, NY: Oxford University Press.

Soss, J., Schram, S. F., Vartanian, T. P., \& O’Brien, E. (200 I). Setting the terms of relief: Explaining state policy choices in the devolution revolution. American Journal of Political Science, 45(2), 378-395.

Steketee, M., Mak, J., \& Tierolf, B. (2009). Kids Count data book 2009. Children rights as the basis for local youth policy. [In Dutch: Kinderen in Tel databoek 2009. Kinderrechten als basis voor lokaal jeugdbeleid.]. Utrecht, The Netherlands: Verwey-Jonker Instituut.

Sugiyama, N. B. (2008). Theories of policy diffusion: Social sector reform in Brazil. Comparative Political Studies, 4 I (2), I 93-2 I6. doi: I 0. I I 77/00 I04 I 40073009 6

Timmerman, G. (2009). Youth policy and participation: An analysis of pedagogical ideals in municipal youth policy in the Netherlands. Children and Youth Services Review, 3 I (5), 572-576.

Tolbert, C. J., Mossberger, K., \& McNeal, R. S. (2008). Institutions, policy innovation, and e-government in the American states. Public Administration Review, 68(3), 549-563.

Van Montfoort, A. J., \& Tilanus, C. P. G. (2007). Jeugdzorg \& jeugdbeleid. Amsterdam: SWP Publishers.

Vink, C. (2007). Engelse inspiratie voor Nederlands jeugdbeleid. Jeugd En Co Kennis, I (4), I 24-I 28.

Volden, C. (2006). States as policy laboratories: Emulating success in the children's health insurance program. American Journal of Political Science, 50(2), 294-3 12.

Walker, J. L. ( 1 969). Diffusion of innovations among American States. American Political Science Review, 63(3), 880899.

Ware, A. ( 1 992). Activist-leader relations and the structure of political parties: "Exchange" models and vote-seeking behaviour in parties. British Journal of Political Science, 22 (० I ), 7 I-92. 


\section{APPENDIX A.}

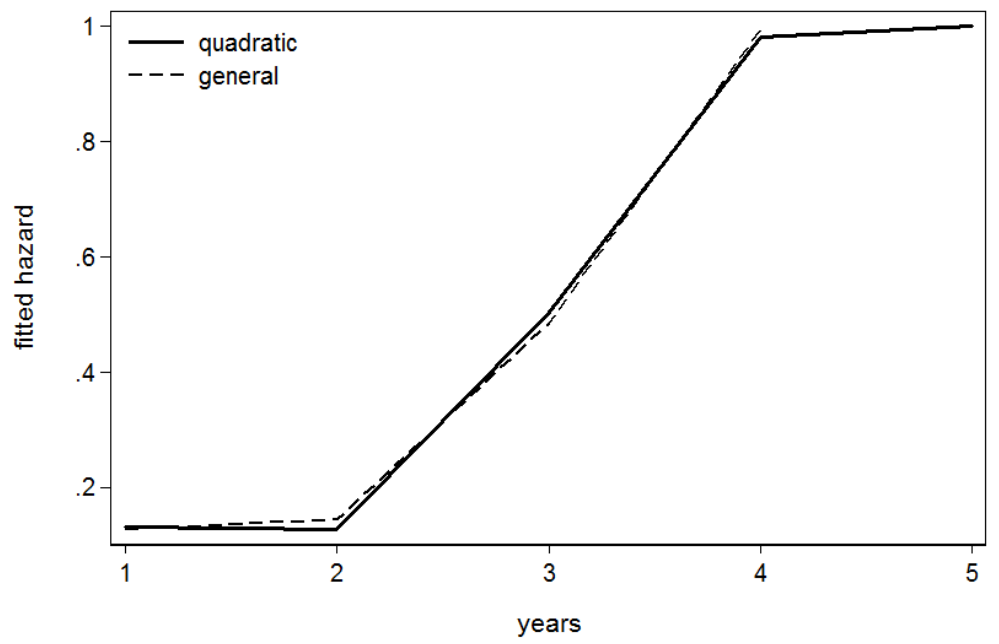

Figure A1. Fitted hazard function for the number of years until CYF adoption, with quadratic polynomial for the main effect of time (years).

Table A1. Justification for the specification for the control variable time.

\section{Difference in deviance in comparison to}

\begin{tabular}{|c|c|c|c|c|c|c|}
\hline \multirow[b]{2}{*}{$\begin{array}{l}\text { Representation for } \\
\text { time }\end{array}$} & \multirow[b]{2}{*}{$\begin{array}{l}\mathrm{n} \text { parame- } \\
\text { ters }\end{array}$} & \multirow[b]{2}{*}{ Deviance } & & \multirow[b]{2}{*}{$\mathrm{AIC}$} & \multirow[b]{2}{*}{$\mathrm{BIC}$} \\
\hline & & & Previous model & General model & & \\
\hline Constant & I & I $458.3 \mathrm{I}$ & $\begin{array}{ll}--- \\
--\end{array}$ & 488.30 & I 460.31 & I 464.25 \\
\hline Linear & 2 & 1051.28 & 407.03 & 81.27 & I 055.28 & 1063.16 \\
\hline Quadratic & 3 & 972.96 & 78.32 & 2.95 & 978.96 & 990.79 \\
\hline Cubic & 4 & $970.0 \mathrm{I}$ & 2.95 & 0.00 & $978.0 \mathrm{I}$ & 993.78 \\
\hline General & 4 & $970.0 \mathrm{I}$ & ----- & ---- & $978 . \circ \mathrm{I}$ & 993.78 \\
\hline
\end{tabular}




\section{NOTES}

${ }^{1}$ Ministries involved were the Ministry of Health, Welfare, and Sport (In Dutch: Ministerie voor Volksgezondheid Welzijn en Sport (VWS)), the Ministry of Education, Culture, and Science (In Dutch: Ministerie van Onderwijs, Cultuur en Wetenschap (OCW)), Ministry of Housing, Spatial Planning and the Environment (in Dutch: Ministerie van Volkshuisvesting, Ruimtelijke Ordening en Milieubeheer (VROM)), the Ministry of the Interior and Kingdom Relations (In Dutch: Ministerie van Binnenlandse Zaken (BZK)), Ministry of Social Affairs and Employment (In Dutch: Ministerie van Sociale Zaken en Werkgelegenheid (SoZa)), Ministry of Finance (In Dutch: Ministerie van Financien (MINFIN)), Ministry of Justics (In Dutch: Ministerie van Justitie (Justitie)).

2 In Belgium there is a Minister of Culture, Media and Youth (http://www.vlaanderen.be/nl/vlaamseregering/vlaams-minister-van-cultuur-media-jeugd-en-brussel), in Germany there is a Minister of Family, Senior Citizens, Women and Youth (http://www.bmfsfj.de/), in France there is a Minister of Youth, Sports and Community Life (http://www.sports.gouv.fr/), and in the UK there is a Minister of State for Children and Families (https://www.gov.uk/government/ministers/minister-of-state-children-and-families). All webpages are visited on ०6-०5$20 \mathrm{I} 5$.

${ }^{3}$ To check for representativeness in terms of size we used a classification used by Statistics Netherlands: < 5, 000 ; 5,000-I0,000; I0,000-20,000; 20,000-50,000; 50,000-I00,000; I00-000-I 50,000; I 50,000-250,000; > 250,000 .

${ }^{4}$ A confirmatory factor analysis (CFA) with the principal component (PA) extraction method, that was forced to look for one dimension, made us decide to remove the items public playgrounds and infant mortality. We constructed a scale from the ten remaining items. The eigenvalue was above 3.9, and the communalities of the ten single items were all above 0.30 except for two (which were 0.225 for infant mortality and 0.286 for school absenteeism), but these two items are substantively important and are therefore included in our scale. The test for the internal reliability of our scale resulted in a Cronbach's alpha $(\alpha)$ of 0.806 , which is good.

${ }^{5}$ For the years 2008-2009 we used information from September 2006, and for the years 2010-201 2 we used information from August 20 I 0 . In both cases these data cover the composition of the BMA after local elections, that were respectively in March 2006 and March $20 \mathrm{I} 0$.

${ }^{6}$ National elections were held in November 2006, and June 20 I 0 . Local elections were held in March 2006, and March $20 \mathrm{I}$ ०. From 2008 (year I) to $20 \mathrm{I} \circ$ (year 3) we compare the results of the local elections in 2006 with the results of the national elections in 2006. From 20 I I (year 4) to 20 I 2 (year 5 ) we compare results from the local elections in $20 \mathrm{I} O$ with the results of the national elections in $20 \mathrm{I} 0$.

7 The information on the local elections of March 2002, March 2006, and March 2010 were retrieved from the website of Freek Ogink (nlverkiezingen.com; visited on 26-6-20 I3). The main source of information for election results for both national and local elections in the Netherlands is the website of the Electoral Council (kiesraad.nl). However, these election results consider local political parties as one broad category, which makes it computationally impossible to calculate the correct differences for all political parties in a municipality between two election periods.

${ }^{8}$ See note I

9 The table in Appendix A shows a comparison of alternative specifications for time (based on calculations proposed by Singer and Willett (2003, Chapter I 2$)$ ) on which basis we conclude that the model with the quadratic polynomial for time functions best, as it performs almost as well as the model with time dummies (general), but it needs less degrees of freedom. The quadratic specification for time outperforms the constant and linear specifications for time, and the cubic polynomial has no benefits over the quadratic specification. The figure in Appendix A shows us that the quadratic polynomial of time is quite capable of recovering the baseline hazard.

${ }^{10}$ The five Wadden Island municipalities Texel, Vlieland, Terschelling, Ameland and Schiermonnikoog were removed from our analyses. They proportionately have a lot of money and manpower for the maintenance of the island. 



\section{CHAPTER 4. E-DEMOCRACY INNOVATION IN DUTCH MUNICIPALITIES BETWEEN 2007 AND 2011'}

\section{ABSTRACT}

E-government has become an important tool for governments to provide its citizens e-services and e-democratic opportunities. This paper studies, for the period 2007-20 I I, differences in development of e-democracy applications among Dutch local governments $(N=407)$. Reasons for governments to undertake specific action for increasing their e-democratic performance must be known for e-democracy to reach its potential. Using pooled regression analysis, the results showed that a combination of governments' motivation to innovate, and the resources they possessed made them develop e-democracy applications more extensively. Municipal governments motivated by a low voter turnout, more potential users, an ideology in favor of egovernment, and politicians with personal preferences favoring e-democracy are more comprehensive e-democracy adherents. Resources beneficial for more extensive e-democracy development were; a larger organizational capacity, better past performance, and a Mayor or Aldermen with specific ICT responsibilities. One factor often discussed in the literature as an obstacle for innovation, party fragmentation, appeared to be an incentive for innovation in this case, and some other factors, such as professional networks, were not significant.

\section{Background and research question}

The developments in information and communication technologies (ICT), especially the easy access to information through the Internet from the mid- I 99os onwards, allowed for a rapid worldwide diffusion of e-government practices. National, federal, state, and local governments are increasingly relying on the Internet to communicate and complete transactions with citizens (McNeal, Tolbert, Mossberger, \& Dotterweich, 2003; West, 2005). West (2005, p. 8) distinguishes four stages, although not mutually exclusive or occurring in a strict linear order, of e-government development: "the billboard stage, the partial service-delivery stage, the portal stage with fully executable and integrated service delivery, and interactive democracy with public outreach and accountability enhancing features”. In the early years of e-government, the late i 990 s and early 2000 s, governmental websites were mainly in the first billboard stage, and were foremost used for one-way information dissemination

\footnotetext{
'Jans, W., Mossberger, K., Denters, B., Need, A., \& Van Gerven, M. (20 I 5). E-democracy innovation in Dutch municipalities between 2007 and 20 I I. Manuscript submitted for publication.
} 
(Coursey \& Norris, 2008; Musso, Weare, \& Hale, 2000). In the years following, governments showed much effort in stages two and three, often referred to as e-service, by adopting and developing two-way electronic service delivery (McNeal et al., 2003; Rodríguez Domínguez, García Sánchez, \& Gallego Álvarez, 20 I I; Torres, Pina, \& Acerete, 2006). In the fourth and last stage, also referred to as e-democracy, governments put effort in providing citizens with access to digital information about political processes and policy choices, as well as enhancing citizen participation in government online (Ahn, 20 I I; Calista \& Melitski, 20 I 3; Kim \& Lee, 20 I 2; Kolsaker \& Lee-Kelley, 2007; Lee, Chang, \& Berry, 20 I I; Yun \& Opheim, 2० I ०). Often, e-government applications are adopted and implemented by governments as a means to improve government performance, and simultaneously also to improve the quality of democracy (Kolsaker \& Lee-Kelley, 2007). We consider e-service and e-democracy to be related but distinct applications of e-government. In respectively the third and fourth stage of e-government development, they are exploited for different purposes: the delivery of public services and the support of democratic processes. Both e-service and edemocracy have become valuable tools for governments in their relationship with citizens (Lee et al., 20 I I). However, relatively unexplored are the determinants contributing to use of e-democracy applications by governments over time (Lee et al., 20 I I). Consequently, in this paper we explain the variation between municipalities in the development of edemocracy applications.

The development of e-democratic applications by public authorities is assumed to increase political participation (Kruikemeier, van Noort, Vliegenthart, \& de Vreese, 20I4; Tolbert \& McNeal, 2003), democratic responsiveness (West, 2004), trust in government (Tolbert \& Mossberger, 2006), and government transparency and accountability (Manoharan, 20 I3). In general it is agreed on that e-democracy has the potential to change the relationship between governments and citizens. Whether in reality the democratic opportunities of e-government are adequately exploited, both in terms of its implementation and in terms of its effects, is regularly empirically explored (Andersen et al., $2 \circ \mathrm{s} \circ$; Bekkers \& Homburg, 2007). Therefore it is important to understand the factors driving governments to undertake specific actions developing e-democracy applications.

We add to the few studies emphasizing the extent and reasons for governments' actions in e-democracy (Calista \& Melitski, 20 I3; Lee et al., 20 I I; Tolbert \& Mossberger, 2006; Yun \& Opheim, 2010). We do so for all Dutch municipalities by answering the question: "How can we explain differences in the extent of e-democracy development on municipalities' websites for the period 2007-20 I I?".

The scientific progress we aim for is twofold. First, we contribute to scholarly work on characteristics explaining differences in the variation of innovativeness across governments (for example, Boehmke \& Skinner, 20 I 2; Walker, I 969). We do so by testing a theory that has been widely applied to other policy fields, such as redistributive or moral policies, in the 
field of implementation of administrative policies (see also, McNeal et al., 2003). We consider the continuous adaptation and improvement of existing e-government applications, the replacement of old applications by new applications, and the implementation of new egovernment applications, to be all new, and hence as adoptions of innovations (see also, Ebbers \& Van Dijk, 2007). This way innovation is also defined in the diffusion literature, that is, as the introduction of a policy or program that is new to the government adopting it, regardless of how many other governments may already have adopted that innovation (Berry \& Berry, 2007, p. 223; Walker, i969, p. 88 I). Approaching the development of edemocracy applications by local governments as (the ongoing) adoption of innovations broadens the potential application of the existing general literature on the diffusion of policy innovations.

The second way to improve upon earlier studies is by studying the developments in edemocracy over a longer time period. Many studies observe the extent of innovation in egovernment at a single period of time (for example, Ahn, 20 I I; García-Sánchez, RodríguezDomínguez, \& Gallego-Álvarez, 20 I I ; Lee et al., 20 I I; McNeal et al., 2003). However, it is important to account for changes over time (Boehmke \& Witmer, 2004; Clark, I 985 ; Hays, I 996). For example, it has been found that governments' scope of policy innovation, their sophistication, and whether they keep pace with state-of-the art developments in the field are subject to change (Tolbert, Mossberger, \& McNeal, 2008). The argument of constantly changing and evolving policies especially applies to policies that continually reappear on the governmental agenda (Glick \& Hays, I 99I), such as e-government. To understand which factors are shaping e-governance innovation across different years, we analyze variations in the extent of e-democracy innovation by Dutch municipalities for a five year long time period (2007-20 I I ).

Municipalities in the Netherlands ( $\mathrm{N}=443$ in 2007) are ideal cases to study differences in edemocracy development for two reasons. ${ }^{\text {I }}$ First, municipalities are in direct contact with citizens and are responsible for the quality of local democracy. The Netherlands is a decentralized unitary state (Pollitt \& Bouckaert, 2004), consisting of three tiers of government: national government, provinces and municipalities. Each governing body is formed on the basis of independent democratic elections, as a rule held once every four years. Dutch municipalities are relatively autonomous in relation to the provinces and central government, as they have a general power of competence to implement what is considered necessary at the local level, as long as this does not conflict with higher order laws (Denters \& Klok, 2005).

Second, municipalities are responsible for providing a considerable amount of basic services, including the execution of e-government applications. Internet access in Dutch households is very large (94\% in 20 I I), making the Netherlands one of the highest scoring countries in Europe, according to the Eurostat 'Survey on ICT' (Seybert, 20 I I ). All municipalities had adopted well before 2003 a functioning website, all of which have been subject 
to constant change and development (ICTU, I 999-20 I I). Participation of municipalities in the development of e-government applications is voluntary and not mandated by the national government. This municipal discretion allows for differences between municipalities in the extent of e-democracy implementation, and offers a perfect possibility to test hypotheses that can explain these differences.

\section{Theory and hypotheses}

To explain municipal differences, we derive hypotheses from a theory originally designed to explain variations in the implementation of innovations across governments, and we test them in a context in which we define innovativeness as the ongoing improvement of edemocracy. We assume that motivation and resources are positively related to innovativeness, and that obstacles are negatively related to innovativeness (Mohr, I 969, p. I I 4). This rational choice approach assumes that actors choose actions suiting their preferences and desires (Hedström, 2005, p. 6r ). Based on the information available, and after assessing their payoffs, municipalities make informed judgments about the available options and act accordingly. Motivation, resources and obstacles may be affected by internal political, economic, and societal conditions, along with external conditions (Berry \& Berry, 2007; Karch, 2007). We accommodate these mechanisms in a model of policy innovation as developed by Berry and Berry (2007) that combines the motivation, obstacles, and resources to innovation (compare, Mohr, I 969). Our most general hypothesis is that when municipalities are strongly motivated, when the obstacles they encounter are low, and when they have more resources available, they will develop e-democracy applications to a larger extent than if the opposite is true.

Below, we will derive our concrete hypotheses from the general literature on innovations and from the more specific literature on innovations in e-government, and where possible we connect to the more specific but sparse literature on e-democracy.

\subsection{Motivation}

Reasons for governments to come up with new policies or with changes to existing policies may come from their motivations to introduce that particular innovation (Berry \& Berry, 2007; Mohr, I969). In the context of rational choice theory a distinction between policyseeking motivations and vote-seeking motivations is made (Braun \& Gilardi, 2006; Budge \& Laver, I 986; Robertson, I 976). The primary motivations of policy-seeking parties lies with the enactment of particular policies, whereas the vote-seeking parties are primarily motivated by the desire to attract votes in order to win elections and thereby securing the direct rewards of office (Budge \& Laver, I 986). In both cases we assume more strongly motivated municipalities to develop e-democracy to a larger extent than less motivated municipalities. 
We will derive specific hypothesis from this general assumption: five policy-seeking hypotheses, and one vote-seeking hypothesis.

\section{Policy-seeking parties: problem severity and citizen demands}

First, policy-seeking parties and politicians can be motivated by a desire to act as competent problem-solvers, or as leaders responsive to citizen demands and needs. We might thus expect that local politicians are motivated to adopt a particular new policy if it promises to alleviate or solve major local problems, or if it meets urgent local needs. If problems are severe, or when local needs are higher, local politicians are more willing to adopt this new policy (Berry \& Berry, 2007; Karch, 2007). We start with presenting two contradictory hypotheses concerning the effect of voter turnout; low participation in elections can be considered a problem, but high participation in elections can be considered a demand. First, from a democratic perspective, a low degree of electoral participation in elections may be considered as a political problem, because it may cause problems of legitimacy and an unequal representation of voters' interests (Lijphart, I 997; Lutz \& Marsh, 2007). In recent decades, voter turnout during municipal elections in the Netherlands has been decreasing steadily, which in general has increased the awareness of a possible political legitimacy problem (Andeweg \& Irwin, 2009, p. I ०4). ${ }^{2}$ It has been argued that there certainly is a desire on the part of governments to engage citizens online to improve the legitimacy of decisions and to reverse the trend of disengagement (Kolsaker \& Lee-Kelley, 2007, p. 36). In the Netherlands local politicians who were confronted with low or declining turnout rates have adopted measured to increase electoral turnout in local elections (Gilsing, I 994). Hence we assume that both, the actual (low) level of turnout, as well as a strong decline in turnout can be a motivation for municipalities to develop e-democracy applications to a larger extent.

( $\mathrm{H}_{\mathrm{I}}$ ) Turnout Hypothesis I: Municipalities with a low voter turnout have more extensive edemocracy development than municipalities with a high voter turnout.

(H $\left.\mathrm{H}_{\mathrm{b}}\right)$ Turnout Change Hypothesis I: Municipalities with a higher decline in voter turnout have more extensive e-democracy development than municipalities with a lower decline in voter turnout.

There is a second perspective that leads to contradictory expectations regarding the impact of voter turnout on policy making. A low degree of electoral participation may also be considered an indicator for a low degree of local political interest, and as a genuine lack of demand or need for (new) channels of active citizen involvement (Ahn, 20 I I; Tolbert et al., 2008). Low degrees of political involvement indicate a lower demand (or need) for new edemocratic services, like digital political information, and online participation possibilities. To the extent that politicians and parties are responsive to such demands and needs, we may 
expect that lower levels of turnout, as well as a decrease in voter turnout can be interpreted as indicators for a lower demand for the development of e-democracy applications.

(H2a) Turnout Hypothesis II: Municipalities with a low voter turnout have less extensive edemocracy development than municipalities with a high voter turnout.

$\left(H_{2} b\right)$ Turnout Change Hypothesis II: Municipalities with a lower decline in voter turnout have less extensive e-democracy development than municipalities with a higher decline in voter turnout.

In addition to turnout there are other indicators for citizen demands, like the current Internet use in a municipality (García-Sánchez et al., 20 I I; Tolbert et al., 2008; Torres et al., 2006). In the Netherlands, higher educational levels are positively related to the use of egovernment applications, whereas age is negatively related to the use of governmental services online (van Dijk, Pieterson, van Deursen, \& Ebbers, 2007). We assume that when more citizens potentially make use of the Internet in the search for governmental information, politicians and policy makers feel motivated to develop a broader array of egovernment services, including e-democracy.

$\left(H_{3}\right)$ Potential Users Hypothesis: Municipalities with more potential Internet users have more extensive e-democracy development than municipalities with fewer potential Internet users.

Policy-seeking parties: ideology

Policy-seeking parties and politicians may also innovate due to ideologically related policy preferences (Berry \& Berry, 2007; García-Sánchez et al., 20 I I; Tolbert et al., 2008). Especially rank-and-file party members may be championing such ideological preferences (Robertson, I 976). Elected representatives in the local council can influence political decision-making about setting priorities in the distribution and use of resources, including edemocratic measures; the objectives of which are eminently political in nature. Furthermore, politicians are the main actors in the decision making process about the future development of e-government applications (Rodríguez Domínguez et al., 20 I I). Innovations may be more or less attractive for ideological reasons when they promise to provide a solution that is ideologically salient to a particular party.

As for e-democratic innovations, it has been argued that e-government applications, like other ICT applications in government, allow for a more business-like approach to government. Parties and politicians that emphasize more business-like and efficient public management and governance are therefore more inclined to adopt such new technologies in government (García-Sánchez et al., 20 I I McNeal et al., 2003), because they hold the prom- 
ise of cost reductions and more efficient procedures. In the Netherlands, the Liberal Party (VVD) is traditionally associated with the development of business-like management and public sector efficiency.

$\left(\mathrm{H}_{4}\right)$ Government Ideology Hypothesis: Municipalities with a more liberal government ideology have more extensive e-democracy development than municipalities with a less liberal ideology.

Moreover, personal preferences of politicians can provide a motivation to introduce edemocratic applications. It has been argued that individuals who advocate new policy ideas and are willing to put energy in bringing these ideas to the attention can be critical for the implementation of new policies (Berry \& Berry, 2007, p. 237; Mintrom \& Norman, 2009).

$\left(\mathrm{H}_{5}\right)$ Personal Preferences Hypothesis: Municipalities with more e-democracy advocates have more extensive e-democracy development than municipalities with fewer e-democracy advocates.

Vote-seeking parties

Parties and politicians also have to consider their prospects of winning elections and mobilizing electoral support. In the literature on e-government innovations, party competition has been often linked to governments' innovativeness in e-government (García-Sánchez et al., 20 I I; McNeal et al., 2003; Tolbert et al., 2008). The argument is that the higher the degree of political competition, the more motivated parties - whatever their ideological orientations - would be for the adoption and implementation of new programs, because local politicians assume that embracing such new programs is likely to increase their electoral support (Berry \& Berry, 2007; García-Sánchez et al., 20 I I).

(H6) Party Competition Hypothesis: Municipalities with higher levels of party competition have more extensive e-democracy development than municipalities with lower levels of party competition.

\subsection{Obstacles}

Here we derive a hypothesis pertaining to the second factor of Mohr ( I 969); the obstacles to innovation. Obstacles can hinder the adoption and implementation of new policies (Berry \& Berry, 2007; Mohr, I 969). We assume that municipalities that have more obstacles will develop e-democracy applications to a lesser extent than municipalities with fewer obstacles. From this general obstacles hypothesis we derive one specific prediction. 
It has been argued that party fragmentation is an obstacle for innovation (Brooks, 2005; $\mathrm{McNeal}$ et al., 2003). A more politically fragmented environment can lead to more difficulties in the decision making process (Brooks, 2005; McNeal et al., 2003), because different viewpoints and diverging interests are to be considered.

$\left(\mathrm{H}_{7}\right)$ Party Fragmentation Hypothesis: Municipalities with higher levels of party fragmentation have less extensive e-democracy development than municipalities with lower levels of party competition.

\subsection{Resources}

We will now derive hypotheses pertaining to the third Mohr ( I 969) factor: a governments' command over financial, human, and social resources (Berry \& Berry, 2007). The resources we discuss below are reflecting resources of governments that are relevant in shaping the constant modification of digital public policy. We assume that municipalities with more resources -more revenues, a higher quantity and quality of staff, and greater levels of access to important networks, will develop e-democracy applications to a larger extent than municipalities with fewer resources. From this general resources hypothesis, we derive two predictions reflecting financial and human resources, and two predictions pertaining to the social networks municipalities are in.

First, it has been argued that organizational capacity, which refers to a governments' command over financial and human capital, is an important resource in the adoption and diffusion of innovations (Berry \& Berry, 2007; Walker, I 969). Governments that are financially more secure and have larger staffs are considered to have a greater capacity to plan and develop innovations, and they may also be less concerned about the costs of innovations. Organizational capacity has been found to influence the adoption of e-government practices (Ahn, 20 I I ; Musso et al., 2000), and also the extent of development of different forms of egovernment (Manoharan, 20 I 3; Tolbert et al., 2008).

(H8) Organizational Capacity Hypothesis: Municipalities with greater organizational capacity have more extensive e-democracy development than municipalities with smaller organizational capacity.

Second, it has been argued that organizational expertise within the e-government policy field is an important resource for potential progress in that field (Ahn, 20 I I; Moon, 2002). Indeed, research has shown that governments' ability to implement new forms of egovernment depends on their prior experience, for example measured by the degree of institutional information technology (IT) infrastructure (Tolbert et al., 2008), website longevity (Manoharan, 20 I 3), or the yearly accumulation of a state government's digitalization (Yun \& 
Opheim, 2010). Therefore, we expect that municipalities that in the past have performed better in e-government are more resourceful and have higher standards in e-democracy development.

(H9) Past Performance Hypothesis: Municipalities with better past performance in egovernment have more extensive e-democracy development than municipalities with poorer past performance.

Third, it has been argued that political attention for a specific policy or policy area functions as an important resource, because the policy priorities of governments determine the amount of allocated resources for the development of policies (Jacoby \& Schneider, 200 I). Governments may have set priorities in the e-government domain which can become visible in the decision to opt for a specific ICT portfolio for the main governing body of a municipality (Homburg \& Dijkshoorn, 20 I I ), which is the Board of Mayor and Aldermen (BMA). We assume that if a municipality has a mayor or aldermen with ICT in its portfolio it has allocated more personal and financial resources to the development of e-democracy innovations.

(H I $_{\mathrm{O}}$ ) ICT Portfolio Hypothesis: Municipalities with a BMA with ICT in its portfolio have more extensive e-democracy development than municipalities without such a function.

Fourth, governments do not function in isolation, and therefore horizontal networks can be considered as a social resource. By facilitating information sharing, professional networks are important places to acquire and exchange relevant policy information (Balla, 200I; McNeal et al., 2003; Sugiyama, 2008). Meetings, in which government representatives can discuss the latest relevant developments, standards, and innovations over a wide range of issues, better inform persons in these networks. We argue that leadership in a professional network creates important social resources that are beneficial for the development of edemocracy.

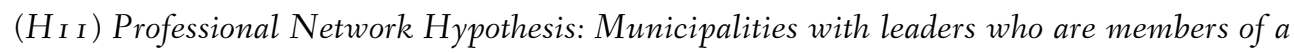
professional network have more extensive e-democracy development than municipalities without persons with such a function.

\section{Methods and data}

To answer our research question about the differences between municipalities in the extent of e-democracy development, we constructed a scale based on the E-Government Monitor (in Dutch: Overheid.nl Monitor) (ICTU, I 999-20 I I) that was commissioned by the Minis- 
try of the Interior and Kingdom Relations (in Dutch: Ministerie van Binnenlandse Zaken en Koninkrijksrelaties (BZK)). ${ }^{3}$ For each year under study (2007-20 I I ), websites of municipalities ( $\mathrm{N}=443$ in 2007) were examined using a standard checklist. ${ }^{4}$ The scores from the monitor allow for a comparison of websites' ability to provide e-government services and democratic e-government content to citizens. The e-democracy scale consists of three subscales: (I) transparency standards, (2) public access to government information, and public engagement, and (3) citizen involvement and participation. ${ }^{5}$ The transparency standards sub-scale consist of I 3 different items, including announcements and notifications concerning welfare and spatial plans, possibilities for subscription to proactive notifications of important announcements, publication of municipal rules and regulations, and whether there is compliance with European transparency directives. The second sub-scale consists of I 2 different items, including publications of textual records of local government meetings, publication of the municipal budget, information about the outside positions of local politicians, and information about the voting behavior of elected representatives. Citizen involvement and participation consist of eight different items, including information about possibilities for citizens to put subjects on the local political agenda, the presence of a citizen's panel, and possibilities for online citizen participation. ${ }^{6}$ On each of the three subscales, which all weight equally important for our final e-democracy scale, the maximum score of roo points could be achieved. This results in the E-DEMOCRACY DEVELOPMENT scale that is measured on a yearly basis for each municipality with a possible range between $\circ$ and 300 . We analyze the repeated measures of our panel data with pooled OLS regression models. Below, we describe the operationalization of our independent variables.

\subsection{Motivational factors}

VOTER TURNOUT is measured for each municipality for the local elections of 2006 and $2 \circ \mathrm{r} \circ$ by the absolute number of votes, divided by the electorate, and multiplied by $\mathrm{i} \circ \circ$. For reasons of interpretation we subtracted the turnout from I००, so that a higher score on this variable equals a lower turnout. For the years 2007-2009, and 20 10-20 I I we use data from the 2006, respectively 20 I $\circ$ local elections. Data ranges between I 5. I $8 \%$ and $59.60 \%$. We measure VOTER TURNOUT DECLINE with a dummy variable taking a value of one when a municipality experiences a decline in turnout that is larger than the national municipal average, and zero otherwise. For the periods 2007-2009, and 2010-20II, we respectively used data from the 2002 and 2006 local elections, and from the 2006 and $20 \mathrm{I} 0$ local elections. For both variables data comes from the Electoral Council (in Dutch: Kiesraad) (Kiesraad, 2002-20 10).

The amount of potential Internet users as a measure of demand is operationalized by the percentage of YOUNGER PEOPLE in a municipality. According to Van Dijk et al. (2007), 
elderly people score significantly lower on actual and intended usage of e-services. They claim that this is certainly true for 65 years and older, but that differences with younger people become visible at 55 years of age. The absolute number of people aged 55 and younger per municipality (Statistics Netherlands, 2007-20 I I) is divided by the number of inhabitants and multiplied by roo to get a relative measure. The variable ranges between $4 \mathrm{r} \%$ and $66 \%$.

We measure GOVERNMENT IDEOLOGY by the percentage of politicians of the Liberal Party (VVD) in the BMA. Data comes from the VNG. This variable ranges between $\circ \%$ and $67 \%$.

Research into personal experiences with interactive (non-digital) policymaking processes in the Netherlands has shown that less-experienced, female, and non-religious politicians were more motivated to seek support of citizens in the policy process, than were more experienced, male, and religious local politicians (De Vries, 2008). We have reliable measures of the number of males and females in the municipal council, and also of the percentage nonreligious politicians, but unfortunately we have no reliable measure of experience. Thus, to measure the personal preferences of politicians we use the percentage of FEMALE POLITICIANS in the BMA, and the percentage NON-RELIGIOUS POLITICIANS in the BMA. The percentage of non-religious politicians is calculated by subtracting the percentage of politicians from religious parties from ı ००. Religious parties are the Christian Democrats (CDA), the Reformed Protestant Party (SGP), and the Christian Union (CU). ${ }^{7}$ Data comes from the VNG. ${ }^{8}$ Both variables have a range between $\circ \%$ and $100 \%$.

The amount of PARTY COMPETION in a municipality is measured by the amount of electoral volatility between two election periods as calculated by Pedersen ( I 979). For the years 2007-2009 we calculated the volatility for the local elections of 2002 and 2006, and for the years 20I0-20I I for the elections of 2006 and $20 \mathrm{I} 0$. The higher the score, the more political competition a municipal council experiences. Data ranges between 1.7 and 76 , and is collected from the website nlverkiezingen.com (own calculations). ${ }^{9}$

\subsection{Obstacle factor}

We measured the amount of POLITICAL FRAGMENT ATION for each municipality by using the Laakso-Taagepera index ( I 979), which calculates the effective number of political parties in a municipal council by taking into account their relative size. The larger the score, the more fragmented a municipal council is. For the years $2007-2009$ we used data from the 2006 local elections, and for the years 20 I०-20 I I we used data from the 20 I $\circ$ local elections. Data ranges between I.59 and I 0.07 , and comes from the Electoral Council (Kiesraad, 2006-2010). 


\subsection{Resources factors}

The measurement of ORGANIZATIONAL CAPACITY is constructed based on the standardized log transformed scores of the fulltime-equivalent (fte) per ro०० inhabitants (BZK, 2007-20II), and the amount of money municipalities received from the municipal fund per roo० inhabitants (BZK, 2008-20 I I). We combined these two variables into one reliable scale for the years 2007 to 20 I I. For both variables only the scores of 2008 are used, because the scores were highly comparable across all five years (municipal fund correlations $=\mathrm{I} .000$ for all years, the fte correlations are all $>0,893)$. A factor analysis and a subsequent reliability test indicated that one organizational capacity scale could be constructed $(\alpha=$ 0.8 I 4 and eigenvalue $=$ I.697). The variable ranges between -2.99 and 5.37 .

The operationalization we use for municipalities' previous experience with egovernment is the year of WEBSITE ADOPTION. The years in which municipalities adopted a website lie between 1996 and 2003 , resulting in an interval variable varying between $\circ$ and 6. We reversed the scale so that a higher score means earlier adoption. For the construction of this variable we combined several data sources. ${ }^{\text {I }}$

Table 1. Descriptive Statistics ( $\mathrm{N}=1945, \mathrm{~N}$ Clusters $=407)$

\begin{tabular}{|c|c|c|c|c|}
\hline & Mean & sd. & Min. & Max. \\
\hline \multicolumn{5}{|l|}{ Dependent variable } \\
\hline E-DEMOCRACY IMPLEMENTATION & 96.90 & 36.31 & I I.०O & 283.00 \\
\hline \multicolumn{5}{|l|}{ Motivational variables } \\
\hline VOTER TURNOUT & 39.83 & $7 \cdot 32$ & I 5.18 & 59.60 \\
\hline VOTER TURNOUT DECLINE & 0.48 & 0.50 & 0.00 & 1.00 \\
\hline POTENTIAL USERS & 52.55 & 3.06 & 40.63 & 66.37 \\
\hline GOVERNMENT IDEOLOGY & I 8.44 & $\mathrm{I} 7.5 \mathrm{I}$ & 0.00 & 66.67 \\
\hline FEMALE POLITICIANS & I $9.0 \mathrm{I}$ & 20.45 & 0.00 & 100.00 \\
\hline NON-RELIGIOUS POLITICIANS & 69.22 & 23.50 & 0.00 & 100.00 \\
\hline ELECTORAL COMPETITION & I 9.57 & 10.42 & I.67 & 76.03 \\
\hline \multicolumn{5}{|l|}{ Obstacle variable } \\
\hline PARTY FRAGMENTATION & 5.08 & 1.20 & I. 59 & 10.07 \\
\hline \multicolumn{5}{|l|}{ Resources variables } \\
\hline ORGANIZATIONAL CAPACITY & 0.00 & I.०० & -2.99 & $5 \cdot 37$ \\
\hline PAST PERFORMANCE & 2.83 & I.64 & 0.00 & 6.00 \\
\hline ICT PORTFOLIO & 0.69 & 0.46 & 0.00 & 1.00 \\
\hline PROFESSIONAL NETWORK & $0.3 \mathrm{I}$ & 0.46 & 0.00 & 1.00 \\
\hline
\end{tabular}

We measure BMA PORTFOLIO with $\circ$ if a municipality had no mayor or alderman who was responsible for the ICT portfolio, and with I if it had a mayor or alderman with an ICT portfolio. Data comes from the Dutch Association of Municipalities (VNG). ${ }^{\text {I }}$

To measure leadership in a PROFESSIONAL NETWORK we created for each year under study (2007-20 I I) a dummy variable taking the value of I if a municipality had rep- 
resentation in the leadership of a Provincial VNG Department, and $\circ$ in all other instances. The provincial VNG boards usually composed of mayors and aldermen, and only occasionally also of local councilors. These provincial departments provide for the task of informing municipalities about issues that arise in the province, and they also represent the interests of the municipalities in the respective province. Data is self-collected from the annual reports of the provincial departments. Table I presents the means, standard deviations, and range of the variables used in our analyses.

\section{Analyses and Results}

To take into account the fact that we have panel data with multiple observations per municipality for the period 2007-20 I I, we analyze the data with pooled ordinary least squares (OLS) regression models. A major advantage of using multiple observations for each municipality is increased precision in the estimation of the regression coefficients (Cameron \& Trivedi, 2005). However, it is likely that the errors of individual municipalities are correlated over time. That is why for panel data it is essential that OLS standard errors be corrected for clustering (Cameron \& Trivedi, 2009). In our models, we use cluster-robust standard errors that cluster on the individual municipalities. Another advantage of panel data is the possibility to account for unobserved individual heterogeneity that may be correlated with independent variables (Cameron \& Trivedi, 2005). In order to correct for possible problems of unobserved heterogeneity at the municipal level, we included year-dummies in all our models. The pooled OLS parameters are estimated using Stata/IC I 3. I . Regression diagnostics were performed and only revealed some minor problems. First, five influential cases were removed from our analyses. ${ }^{\mathrm{I} 2}$ Second, not all independent variables showed a linear relationship with our dependent variable. Therefore, we transformed the variable measuring the percentage female politicians in a municipal council into three approximately equally sized categories; $0 \%, \mathrm{I}-25 \%$, and $>25 \%$, and the variable measuring the percentage nonreligious politicians in a municipal council also into three approximately equally sized categories; $<=50 \%, 5 \mathrm{I}-75 \%$, and $>75 \%$. Third, residuals were normally distributed, and heteroscedasticity and multicollinearity tests showed no difficulties.

In table 2 we present the results of our model estimations. For each variable the coefficients are shown with their standard errors in parentheses beneath. Interval variables are standardized so that they have a mean of zero and a standard deviation of one. Coefficients can be interpreted that, holding the other variables constant at their mean values (interval) or lowest values (categorical), a one-unit increase is associated with an increase in the dependent variable equal to the magnitude of the effect. Model I examines the relationship between motivational factors and the extent of e-democracy development, in model 2 we examine the relationship between e-democracy development and the one identified obstacle, and in the third model the association between resources and e-democracy development 
is investigated. In our final model we simultaneously test for the influence of motivation, obstacles and resources.

Model $\mathrm{I}$ in table 2 shows the coefficients of the variables capturing municipalities' motivation to innovate in e-democracy. We expected that in general, municipalities with a higher motivation to innovate developed e-democracy applications to a larger extent. The coefficient of the voter turnout variable is statistically different from zero $(p=0.000)$ and its positive sign indicates that if the voter turnout in a municipality decreases with one-unit ( $\mathrm{I}$ sd.), that the e-democracy score increases with 5.39. This finding offers an initial confirmation of hypothesis ra, and an initial rejection of hypothesis $2 \mathrm{a}$. The coefficient of the potential users variable, measured by the percentage of young people in a municipality, shows up positive and significantly different from zero $(p=0.000)$. The positive sign of the coefficient indicates that a one-unit ( $\mathrm{s}$ sd.) change is associated with a 7.02 increase on the edemocracy development scale. We found this to support, at least provisionally, our hypothesis 3. The coefficient of government ideology variable, which measures the percentage of liberals in the BMA, shows up significant, and its positive sign points in the predicted direction $(p=0.035$ ). A one-unit ( $\mathrm{d}$ ds.) increase on this variable means a 2.63 increase on the edemocracy development scale. This initially confirms hypothesis 4 . The coefficients of dummy variable associated with the percentage of female politicians in the BMA shows us that compared to municipalities with no female politicians in the coalition, having between one and 25 percent females increase the extent of e-democracy development with $5.0 \mathrm{I}$, and having over 25 percent females is associated with an increase of 5.16. We included two different measures to account for the effect of politicians' personal preferences, namely the percentage of female politicians and the percentage of non-religious politicians. Because the coefficients of the latter one failed to attain the necessary levels of statistical significance we found these results to be a temporary and only partial confirmation of hypothesis 5 . The voter turnout decline variable and the electoral competition variables failed to attain the necessary levels of statistical significance and thus appear to be unrelated to the extent of edemocracy development. Hypotheses $2 \mathrm{~b}$ and 6 , are therefore provisionally refuted.

Model 2 of table 2 shows the regression results of the obstacle variable. Our assumption was that municipalities facing more obstacles would develop e-democracy to a lesser extent. Contrary to what we expected the political fragmentation coefficient showed up positive and statistically different from zero $(p=0.000)$. We therefore provisionally refute hypothesis 7 .

In model 3 in table 2 we find the regression coefficients of the resources variables. Our general assumption was that more resourceful municipalities would develop e-democracy applications to a larger extent. The organizational capacity variable shows up statistically different from zero $(p=0.000)$ and its positive sign is in the expected direction. Its coefficient means that a one-unit ( I sd.) increase is associated with a 7. I I higher e-democracy score. This offers an initial confirmation of hypothesis 8 . The positive coefficient of the past 
Table 2. Pooled OLS Regression coefficients explaining the extent of E-democracy implementation $(\mathrm{N}=1945, \mathrm{~N}$ Clusters $=407)$

\begin{tabular}{|c|c|c|c|c|}
\hline & $\begin{array}{l}\text { Model I } \\
\text { beta/se }\end{array}$ & $\begin{array}{c}\text { Model } 2 \\
\text { beta/se }\end{array}$ & $\begin{array}{c}\text { Model } 3 \\
\text { beta/se }\end{array}$ & $\begin{array}{c}\text { Model } 4 \\
\text { beta/se }\end{array}$ \\
\hline \multicolumn{5}{|l|}{ Motivational variables } \\
\hline VOTER TURNOUT & $\begin{array}{l}5.39 \mathrm{I}^{* *} \\
(\mathrm{I} .433)\end{array}$ & & & $\begin{array}{l}2.855^{+} \\
\left(\mathrm{I} .55^{\mathrm{I}}\right)\end{array}$ \\
\hline VOTER TURNOUT DECLINE & $\begin{array}{l}-3.963 \\
(2.597)\end{array}$ & & & $\begin{array}{c}0.282 \\
(2.599)\end{array}$ \\
\hline POTENTIAL USERS & $\begin{array}{l}7.017^{* *} \\
(1.428)\end{array}$ & & & $\begin{array}{l}4.834^{* *} \\
(1.428)\end{array}$ \\
\hline GOVERNMENT IDEOLOGY & $\begin{array}{l}2.632^{*} \\
(\mathrm{I} .243)\end{array}$ & & & $\begin{array}{l}2.546^{*} \\
(\mathrm{I} .20 \mathrm{I})\end{array}$ \\
\hline \multicolumn{5}{|l|}{ FEMALE POLITICIANS } \\
\hline $\mathrm{I}-25 \%$ & $\begin{array}{l}5.009^{*} \\
(2.545)\end{array}$ & & & $\begin{array}{c}3.555 \\
(2.526)\end{array}$ \\
\hline$>25 \%$ & $\begin{array}{l}5.164+ \\
(3.035)\end{array}$ & & & $\begin{array}{l}5.689+ \\
(2.995)\end{array}$ \\
\hline \multicolumn{5}{|l|}{ NON-RELIGIOUS POLITICIANS } \\
\hline $5 \mathrm{I}-75 \%$ & $\begin{array}{l}-2.225 \\
(3.190)\end{array}$ & & & $\begin{array}{l}-3.522 \\
(3.167)\end{array}$ \\
\hline$>75 \%$ & $\begin{array}{l}-0.995 \\
(3.283)\end{array}$ & & & $\begin{array}{l}-2.969 \\
(3.234)\end{array}$ \\
\hline ELECTORAL COMPETITION & $\begin{array}{l}-0.384 \\
(0.993)\end{array}$ & & & $\begin{array}{l}-0.8 \text { I } 4 \\
(0.944)\end{array}$ \\
\hline \multicolumn{5}{|l|}{ Obstacle variable } \\
\hline PARTY FRAGMENTATION & & $\begin{array}{l}5.234^{* *} \\
(1.067)\end{array}$ & & $\begin{array}{l}3.540^{* * *} \\
(0.94 \mathrm{I})\end{array}$ \\
\hline \multicolumn{5}{|l|}{ Resources variables } \\
\hline ORGANIZATIONAL CAPACITY & & & $\begin{array}{l}7.113^{* *} \\
(1.489)\end{array}$ & $\begin{array}{l}4.93^{* * *} \\
(1.572)\end{array}$ \\
\hline PAST PERFORMANCE & & & $\begin{array}{l}4.8 \text { I } 0^{* *} \\
(\mathrm{I} .477)\end{array}$ & $\begin{array}{l}3.109 * \\
(1.396)\end{array}$ \\
\hline ICT PORTFOLIO & & & $\begin{array}{l}4.648+ \\
(2.435)\end{array}$ & $\begin{array}{l}4.45 \mathrm{I}+ \\
(2.324)\end{array}$ \\
\hline PROFESSIONAL NETWORK & & & $\begin{array}{c}2.2 \mathrm{I} 3 \\
(2.676)\end{array}$ & $\begin{array}{c}2.82 \mathrm{I} \\
(2.534)\end{array}$ \\
\hline Constant & $\begin{array}{c}89.852^{* *} \\
\left(3.5^{8}\right)\end{array}$ & $\begin{array}{c}91.100^{* *} \\
(2.080)\end{array}$ & $\begin{array}{c}86.357^{* *} \\
(2.705)\end{array}$ & $\begin{array}{c}86.393^{* *} \\
(3.937)\end{array}$ \\
\hline$\overline{\mathrm{R}^{2}}$ & 0.130 & $0.06 \mathrm{I}$ & 0.125 & 0.170 \\
\hline $\mathrm{R}^{2-} \mathrm{Adj}$ & 0.124 & 0.058 & 0.122 & 0.162 \\
\hline Dfres & 406.000 & 406.000 & 406.000 & 406.000 \\
\hline
\end{tabular}

**p<0.01, ${ }^{*} \mathrm{p}<0.05,+\mathrm{p}<0.10:$ two-tailed.

Note I: To account for repeated measures, all models are estimated with robust standard errors clustered on individual municipalities. Estimated coefficients with standard errors in parentheses beneath.

Note II: Interval variables are standardized (z-scores), categorical variables are held constant at their lowest values. Year dummies are estimated, but not presented. 
performance variable is also highly significant ( $p=0.00 \mathrm{I})$, and is in the expected direction, providing support for hypothesis 9 . A one-unit ( $\mathrm{s} \mathrm{sd}$.) increase is associated with a $4.8 \mathrm{I}$ increase in e-democracy development. The coefficient of the ICT portfolio variable is significantly different from zero $(p=0.057)$ and its direction is what we expected. Compared to municipalities without a person in the BMA with specific ICT responsibilities, municipalities that have such a person have a 4.65 higher e-democracy development score. We therefore provisionally confirm hypothesis $\mathrm{o} \circ$. The other resource variable, which measures leadership representation in a professional network, is not statistically related to the extent of e-democracy development. We were thus, at least for now, unable to confirm hypothesis i I.

In model 4 in table 2 we simultaneously test for the effects of motivations, obstacles and resources. Estimating the different effects in one model did slightly change the results as described above. The effect of the voter turnout variable is again positive and statistically different from zero $(p=0.066$ ). The effect changed and a one-unit ( 1 sd.) decrease in voter turnout is now associated with a 2.86 higher e-democracy score, compared to 5.39 in model I. Hypothesis r a can now definitely be confirmed, and 2 a can now definitely be rejected. Again, the coefficient of the potential users variable shows up positive and statistically different from zero $(p=0.000$ ). A one unit ( $\mathrm{s}$ sd.) increase is now associated with a 4.83 increase in e-democracy development, compared to 7.02 in model I. We consider these results to definitely confirm hypothesis 3 . The same applies to the coefficient of the government ideology variable, which also again is statistically different from zero $(p=0.35)$. The difference in effect with model I is negligible. Hereby, we confirm hypothesis 4 . The effect of the percentage of female politicians in the BMA did slightly change. Compared to the reference category ( $\circ \%$ women), it only seems to matter to have over $25 \%$ females in the board $(p=0.058)$. Its effect slightly changed compared to model I, from 5. I 6 to 5.69. As explained before, we had two different operationalizations for politicians' personal preferences, and the second one again failed to attain the necessary levels of statistical significance. Nevertheless, we consider these findings to partially support hypothesis 5 . The results for the voter turnout decline variable and the electoral competition variable stay unchanged, which means that they are not related to e-democracy development. Thus, we definitely found no confirmation for hypotheses $2 \mathrm{a}$ and 6 . Also in the final model, the opposite of what we expected was found for the obstacle variable, namely that political fragmentation is positively and significantly $(p=0.000)$ related to the extent of innovation. Thus, we now definitely refute hypothesis 7. Regarding the resources variables, the findings of model 3 stay largely unchallenged, only the magnitude of the effects changed slightly. Again, the organizational capacity variable shows up statistically different from zero $(p=0.002)$, but now a one unit ( I sd.) increase is associated with a 4.94 increase in e-democracy development, as opposed to a 7. I I increase in model 3. We are thus able to definitely confirm hypothesis 8 . The coefficient of the past performance variable is again significant ( $p=0.026$ ), only a one unit ( $\mathrm{s}$ sd.) increase is now associated with a 3.12 increase, instead of a 4.8 I increase in e-democracy 
development. These results confirm hypothesis 9. Model 4 also shows that having someone in the BMA with responsibilities for the ICT portfolio increases the extent of e-democracy development with 4.45 (opposed to 4.65 in model 3 ), supporting hypothesis $\mathrm{I} 0$. The last resource variable, professional network, again failed to attain the necessary level of statistical significance, and thus seems to be unrelated to the development of e-democracy. We now definitely refute hypothesis I I. In Appendix A we present an overview of the test results for all i 3 hypotheses.

In a final analytical step we compare the effect sizes of the latent constructs motivations, obstacles and resources to determine what was the most important for the extent of edemocracy development. Comparing the effect sizes of different blocks of variables is possible by calculating the sheaf-coefficient (Heise, i972), implemented by the sheafcoefpackage in Stata I 3. I (Buis, n.d., 20 Iо). The coefficient of the motivational variables block is $7.172(p=0.000)$, that of the resources block is $7.495(p=0.000)$, and that of the obstacles block is $3.403(p=0.000)$. This means that motivations and resources were approximately equally important for the development of e-democracy.

\section{Conclusion and Discussion}

With the quick developments in information and communication technologies (ICT), new possibilities for the development of electronic government services have been arising. There are different forms of e-government that are being used for different purposes, namely the delivery of services to citizens by electronic means, and secondly, enabling citizens to consume digital democratic information and to participate actively online in the policy process (West, 2005). In the literature, these related but distinct forms of e-government are often referred to as e-service and e-democracy. In this paper we focused on the determinants of edemocracy development on municipalities' websites in the Netherlands. According to many, e-government has the potential to improve government efficiency and effectiveness, not only in the delivery of public services, but also by increasing political participation and democratic responsiveness. Research into the development of e-democracy applications by governments is important, because this gives us insight into why some governments excel in its development and others do not. In many studies innovativeness is defined simply as a dichotomous distinction between adopters and non-adopters, meaning that earlier adoption equals more innovative behavior. However, after their initial introduction, policies are often subject to change, which requires a different measurement of innovation. Following others, we argued that to get an accurate picture of innovation, it is possible to use measures of the extent of policy development (Clark, i 985; Hays, I 996; McNeal et al., 2003). Alongside using this different measure of innovation we investigated developments in e-democracy over a longer period of time. This allowed us to find out what factors really mattered in edemocracy development, because in contrast to cross-sectional studies, we could rule out 
possible confirmations of hypotheses that were due to some random annual circumstances. Furthermore, a strong point of our study is the use of data relating to the variables measuring local political factors. Very often variables measuring political factors are constructed based on the number of votes for particular political parties, but this does not always connect oneto-one with how coalitions are formed after the elections. In our study we have been able to use data from the VNG, the association of Dutch municipalities, to construct the variables government ideology, female politicians, non-religious politicians, and ICT portfolio. Using data from real existing municipal coalitions is beneficial, because ultimately these are the responsible governing bodies of municipalities.

We showed that, by interpreting the development of e-democracy as a form of innovation, it is possible to contribute to the general theory developed by Mohr ( 1 969) and later further developed by Berry and Berry (2007). Researching a specific Dutch e-democracy case we add to the existing body of innovation literature. This theory developed to explain differences in innovativeness across governments proved to be very capable of explaining differences in e-democracy development among governments. As an answer to our research question we found that municipalities that were more strongly motivated, and the ones that had better command over resources developed e-democracy applications to a larger extent. We will first discuss the findings that have not been in line with the theory, and then our main findings.

We found no support for the personal preferences hypothesis, measured by the amount of non-religious politicians in the BMA, indicating that more progressive personal attitudes towards interactive decision-making are not related to e-democracy innovation. Maybe in future research better measurements than our proxy are possible. For example, we would have liked a measure for how experienced politicians are, with the idea that more experienced politicians are less likely to embrace changes like online interaction with citizens in the policy process, and thus less supportive of e-democracy. We found also no support for the effect of electoral competition, which indicates that competition between political parties for voters did not lead to more extensive e-democracy implementation. Furthermore, leadership in a professional network was not a resource for innovation. Interestingly, because opposite to what we expected, party fragmentation was not a barrier to e-democracy implementation, but it was rather an incentive for innovation. An explanation for this finding might be found more in line with one of our motivational expectations, the electoral competition hypothesis. In the literature it has been argued that party fragmentation can lead to a politically more competitive environment (McNeal et al., 2003), which in turn leads to a more innovative environment in order to satisfice citizens. So, maybe politicians are not so sensitive to long-term shifts in votes between parties, as operationalized by our volatility measure of electoral competition, but they might be sensitive to party fragmentation, which can be regarded a more direct visible form of political competition (Denters, I 987 ). 
Our main findings are that it was foremost a combination of the degree of motivation and the amount of resources to innovate that was important for more comprehensive edemocracy development. The local elections-based motivational determinants that we found to be related to the implementation of e-democracy, are an important addition to the current literature that has given only sparse attention to political factors and their relevance for e-government (Ahn, 20 I I). We found that municipalities with a lower voter turnout at one election to be more comprehensive e-democracy developers. This indicates that need for e-democracy played a role. That demand for policy also played a role is confirmed by age characteristics of the population, or the positive effect of potential citizen use of egovernment information. Although there can be agreement on the need or demand for a policy, various political parties can assign different levels of importance to a particular solution to a problem. So far, the results found in the literature have given us a dispersed picture about what political orientations are related to the development of e-government and for what reasons (García-Sánchez et al., 20 I I Rodríguez Domínguez et al., 20 I I). Our study does not end this discussion, but offers a plausible theoretical reasoning, and we were able to confirm our hypothesis about the influence of the liberal party on the extent of e-democracy development. Personal ideological considerations, measured by individual characteristics of politicians did play a role to the extent that having more women in the BMA of a municipality is related to more extensive e-democracy development. Our findings regarding the resources for innovation were reasonably straightforward. Municipalities that have a larger organizational capacity developed e-democracy applications more extensively, which is in line with what has generally been found in the literature (for example, Ahn, 20II; Manoharan, 20I3; Tolbert et al., 2008). Also past performance has proven to be an important resource for e-democracy development, which is also in line with previous research (Ahn, 20 I I; Moon, 2002). We used the year of website adoption as measurement for past performance, which we regard to be a better measure than the commonly used score of the year preceding the year of interest. These measurements quite obviously might suffer from problems of independence. In contrast with some studies of e-government (McNeal et al., 2003; Tolbert et al., 2008), professional networks were not significant predictors. Parties were, however, indicating that e-democracy may be more firmly tied to politicians than administrative networks. The last resource we found to be of significance was a person in the BMA with specific ICT responsibilities. This may indicate the institutionalization of ICT policies in the local government (Tolbert et al., 2008), but it may also represent policy entrepreneurship on the part of the individual so assigned. Although, the idea that "leadership that is open to innovation or sees an electoral payoff from adopting technology can make a tremendous difference in how technologies gets integrated into the public sector" (West, 2005 , p. I 4), it is a rather unexplored empirical phenomenon in e-government innovation studies. Future research should try to shed light on how policy advocates influence the spreading of new policy ideas, because bringing new ideas to the attention of citizens and 
CHAPTER FOUR

politicians can be critical for the development of new policies (Berry \& Berry, 2007, p. 237; Mintrom \& Norman, 2009). 


\section{REFERENCES}

Ahn, M. J. (20 I I). Adoption of Applications in U.S. Municipalities: The Role of Political Environment, Bureaucratic Structure, and the Nature of Applications. The American Review of Public Administration, 4I (4), 428-452. doi: I 0. I I $77 / 02750740$ I 0377654

Andersen, K. N., Henriksen, H. Z., Medaglia, R., Danziger, J. N., Sannarnes, M. K., \& Enemærke, M. (20 I o). Fads and facts of e-government: A review of impacts of e-government (2003-2009). International Journal of Public Administration, 33 ( I I), 564-579.

Andeweg, R. B., \& Irwin, G. A. (2009). Governance and Politics of the Netherlands (3rd ed.). Houndsmills/New York: Palgrave Macmillan.

Balla, S. J. (200 I). Interstate Professional Associations and the Diffusion of Policy Innovations. American Politics Research, 29(3), 22 I-245. doi: I 0. I I 77/I 532673 X0 I 29300 I

Bekkers, V., \& Homburg, V. (2007). The myths of e-government: Looking beyond the assumptions of a new and better government. The Information Society, 23(5), 373-382.

Berry, F. S., \& Berry, W. D. (2007). Innovation and diffusion models in policy research. In P. A. Sabatier (Ed.), Theories of the Policy Process (second., pp. 223-260). Boulder, CO: Westview Press.

Boehmke, F. J., \& Skinner, P. (20 I 2). State policy innovativeness revisited. State Politics E Policy Quarterly, I2(3), 303329.

Boehmke, F. J., \& Witmer, R. (2004). Disentangling diffusion: The effects of social learning and economic competition on State policy innovation and expansion. Political Research Quarterly, 57 ( I), 39-5 I. doi: I O. I I 77/1 106591 290405700104

Braun, D., \& Gilardi, F. (2006). Taking “Galton”s Problem' Seriously. Journal of Theoretical Politics, I 8(3), $298-322$. doi: I O. I I 77/095 I62980606435 I

Brooks, S. M. (2005). Interdependent and domestic foundations of policy change: The diffusion of pension privatization around the world. International Studies Quarterly, 49(2), 273-294.

Budge, I., \& Laver, M. ( I 986). Office seeking and policy pursuit in coalition theory. Legislative Studies Quarterly, $4^{85}-$ 506.

Buis, M. L. (n.d.). Combining information from multiple variables using models for causal indicators. Working Paper.

Buis, M. L. (2० I o). SHEAFCOEF: Stata module to compute sheaf coefficients. Statistical Software Components.

BZK. (2008a). Distribution of payments from the Municipal fund [In Dutch:Verdeling van de uitkeringen uit het gemeentefonds] [Data file]. Retrieved August 2 I, 201 2, from http://www.rijksoverheid.nl/onderwerpen/gemeenten/documenten-enpublicaties/rapporten/20 I I/o7/28/verdeling-van-de-uitkeringen-uit-het-gemeentefonds.html

BZK. (2008b). Municipalities' budget analyses [In Dutch: Begrotingsanalyse gemeenten] [Data file]. Retrieved from http://www.rijksoverheid.nl/documenten-en-publicaties/rapporten/

Calista, D. J., \& Melitski, J. (20 I 3). Digitized Government Among Countries Worldwide From 2003 to 20 I o: Performance Discrepancies Explained by Comparing Frameworks. International Journal of Public Administration, 36(3), 222-234. doi: I 0. 1 080/0 I 900692.2012 .72 I 246

Cameron, A. C., \& Trivedi, P. K. (2005). Microeconometrics: methods and applications. Cambridge University Press.

Cameron, A. C., \& Trivedi, P. K. (2009). Microeconometrics using Stata (Second.). Texas, US: Stata Press.

Clark, J. ( I 985 ). Policy diffusion and program scope: Research directions. Publius, I 5 (4), 6 I-70.

Coursey, D., \& Norris, D. F. (2008). Models of e-government: Are they correct? An empirical assessment. Public Administration Review, 68(3), 523-536.

De Vries, M. S. (2008). Stability despite reforms: structural asymmetries in Dutch local policy networks. Local Government Studies, 34(2), 22 I-243.

Denters, B. ( 1987$)$. Partijen, kiezers en gemeentelijk beleid: een empirische toetsing van een politiek-economische theorie. Dissertation. University of Twente, Enschede, The Netherlands.

Denters, B., \& Klok, P.-J. (2005). The Netherlands in search of responsiveness. In B. Denters \& L. E. Rose (Eds.), Comparing local governance: Trends and developments (pp. 65-82). New York: Palgrave Macmillan.

Ebbers, W. E., \& Van Dijk, J. A. G. M. (2007). Resistance and support to electronic government, building a model of innovation. Government Information Quarterly, 24(3), 554-575. 


\section{CHAPTER FOUR}

García-Sánchez, I.-M., Rodríguez-Domínguez, L., \& Gallego-Álvarez, I. (20 I I). The Relationship between Political Factors and the Development of E-Participatory Government. The Information Society, 27(4), $233-25$ I.

Gilsing, R. ( I 994). Lokale bestuurlijke vernieuwing in Nederland. Acta Politica, 29( I), 3-36.

Glick, H. R., \& Hays, S. P. ( I 99 I). Innovation and reinvention in state policymaking: Theory and the evolution of living will laws. The Journal of Politics, 53 (03), 835-850.

Hays, S. P. ( 1 996). Influences on reinvention during the diffusion of innovations. Political Research Quarterly, 49(०3), 63 I -650 .

Hedström, P. (2005). Dissecting the social: On the principles of analytical sociology. Cambridge University Press Cambridge.

Heise, D. R. ( I 972). Employing nominal variables, induced variables, and block variables in path analyses. Sociological Methods \& Research, I(2), I 47-I 73.

Homburg, V., \& Dijkshoorn, A. (20 I I). Diffusion of personalized e-government services among Dutch municipalities: an empirical investigation and explanation. International Journal of Electronic Government Research, 7(3), 2 I-37.

ICTU. (I 999-20 I I). E-Government ranking municipalities [In Dutch: Overheid.nl monitor gemeenten] [Data file]. Retrieved from http://www.e-overheid.nl/onderwerpen/voortgang-en-planning/overheidnl-monitor/gemeenten

Jacoby, W. G., \& Schneider, S. K. (200 I). Variability in state policy priorities: An empirical analysis. Journal of Politics, $63(2), 544-568$.

Karch, A. (2007). Democratic Laboratories. Policy diffusion among the American states. Ann Arbor: The University of Michigan Press.

Kiesraad. (20 I I). Election Results. [In Dutch: Verkiezingsuitslagen] [Data file]. Retrieved from http://www.verkiezingsuitslagen.nl/Na i 9 i 8/Verkiezingsuitslagen.aspx/

Kim, S., \& Lee, J. (20 I 2). E-Participation, Transparency, and Trust in Local Government. Public Administration Review, 72(6), 8 I 9-828. doi: I 0. I I I I/j. I 540-62 I 0.20 I 2.02593.x

Kolsaker, A., \& Lee-Kelley, L. (2007). "Mind the Gap II”: E-Government and E-Governance. In Electronic Government (pp. 35-43). Springer.

Kruikemeier, S., van Noort, G., Vliegenthart, R., \& de Vreese, C. H. (20 I 4). Unraveling the effects of active and passive forms of political Internet use: Does it affect citizens' political involvement? New Media E Society, I6(6), 903-920. doi: I o. I I 77/ I 46 I 4448 I 3495 I 63

Laakso, M., \& Taagepera, R. ( I 979). The "effective” number of parties: “A measure with application to West Europe.” Comparative Political Studies, I2 (I), 3.

Lee, C., Chang, K., \& Berry, F. S. (20 I I ). Testing the Development and Diffusion of E-Government and E-Democracy: A Global Perspective. Public Administration Review, 7 I (3), 444-454.

Lijphart, A. ( 1 997). Unequal Participation: Democracy’s Unresolved Dilemma. American Political Science Review, 9 I (OI), I-I 4 .

Lutz, G., \& Marsh, M. (2007). Introduction: Consequences of low turnout. Electoral Studies, 26(3), 539-547.

Manoharan, A. (20I 3). A Study of the Determinants of County E-Government in the United States. The American Review of Public Administration, 43(2), I 59-1 78.

McNeal, R. S., Tolbert, C. J., Mossberger, K., \& Dotterweich, L. J. (2003). Innovating in digital government in the American states. Social Science Quarterly, 84(I), 52-70.

Mintrom, M., \& Norman, P. (2009). Policy entrepreneurship and policy change. Policy Studies Journal, 37(4), 649-667.

Mohr, L. B. ( I 969). Determinants of innovation in organizations. The American Political Science Review, 63 (I), I I II 26.

Moon, M. J. (2002). The evolution of e-government among municipalities: Rhetoric or reality? Public Administration Review, 62(4), 424-433.

Musso, J., Weare, C., \& Hale, M. (2000). Designing web technologies for local governance reform: good management or good democracy? Political Communication, I $7(\mathrm{I})$, I-I 9.

Pedersen, M. N. ( I 979). The dynamics of European party systems: changing patterns of electoral volatility. European Journal of Political Research, 7 ( I), I-26.

Pollitt, C., \& Bouckaert, G. (2004). Public management reform: a comparative analysis (2nd ed.). New York, NY: Oxford University Press.

Robertson, D. B. ( I 976). A theory of party competition. London: John Wiley \& Sons. 
Rodríguez Domínguez, L., García Sánchez, I. M., \& Gallego Álvarez, I. (20 I I). Determining factors of e-government development: a worldwide national approach. International Public Management Journal, I 4(2), 2 I 8-248.

Seybert, H. (20 I I). Internet use in households and by individuals in 20 I I. Eurostat Statistics in Focus, 66, 20 I I.

Statistics Netherlands. (2007). The Netherlands regional: Regional key figures, population, composition of the population [In Dutch: Nederland regionaal: Regionale kerncijfers Nederland, bevolking, bevolkingssamenstelling [Data file]. Retrieved from http://www.statline.cbs.nl/

Sugiyama, N. B. (2008). Theories of policy diffusion: Social sector reform in Brazil. Comparative Political Studies, 4 I (2), I 93-2 I 6. doi: I O. I I 77/00104 I 40073009 6

Tolbert, C. J., \& McNeal, R. S. (2003). Unraveling the effects of the Internet on political participation? Political Research Quarterly, 56(2), I 75-I 85 .

Tolbert, C. J., \& Mossberger, K. (2006). The Effects of E-Government on Trust and Confidence in Government. Public Administration Review, 66(3), 354-369.

Tolbert, C. J., Mossberger, K., \& McNeal, R. S. (2008). Institutions, policy innovation, and e-government in the American states. Public Administration Review, 68(3), 549-563.

Torres, L., Pina, V., \& Acerete, B. (2006). E-Governance Developments in European Union Cities: Reshaping Government's Relationship with Citizens. Governance, I 9(2), 277-302.

Van Dijk, J., Pieterson, W., van Deursen, A., \& Ebbers, W. (2007). E-services for citizens: the Dutch usage case. In Electronic government (pp. I 55-166). Springer.

Walker, J. L. ( 1969$)$. Diffusion of innovations among American States. American Political Science Review, 63(3), 880899.

West, D. M. (2004). E-government and the transformation of service delivery and citizen attitudes. Public Administration Review, 64(I), i 5-27.

West, D. M. (2005). Digital government : technology and public sector performance. Princeton, NJ: Princeton University Press.

Yun, H. J., \& Opheim, C. (2० I o). Building on Success: The Diffusion of e-Government in the American States. Electronic Journal of E-Government, 8( I). 
APPENDIX A. Tested hypotheses and their results.

Motivations

Confirmed?

(Hıa) Turnout Hypothesis I: Municipalities with a low voter turnout have more extensive e-democracy development than municipalities with a high voter turnout.

(Hı) Turnout Change Hypothesis I: Municipalities with a higher decline in voter turnout have more extensive e-democracy development than municipalities with a lower decline in voter turnout.

No

(H2a) Turnout Hypothesis II: Municipalities with a low voter turnout have less extensive e-democracy development than municipalities with a high voter turnout.

( $\mathrm{H}_{2}$ b) Turnout Change Hypothesis II: Municipalities with a lower decline in voter turnout have less extensive e-democracy development than municipalities with a higher decline in voter turnout.

$\left(\mathrm{H}_{3}\right)$ Potential Users Hypothesis: Municipalities with more potential Internet users have more extensive edemocracy development than municipalities with fewer potential Internet users.

$\left(\mathrm{H}_{4}\right)$ Government Ideology Hypothesis: Municipalities with a more liberal government ideology have more extensive e-democracy development than municipalities with a less liberal ideology.

$\left(\mathrm{H}_{5}\right)$ Personal Preferences Hypothesis: Municipalities with more e-democracy advocates have more extensive e-democracy development than municipalities with fewer e-democracy advocates.

(H6) Party Competition Hypothesis: Municipalities with higher levels of party competition have more extensive e-democracy development than municipalities with lower levels of party competition.

No Obstacles

$\left(\mathrm{H}_{7}\right)$ Party Fragmentation Hypothesis: Municipalities with higher levels of party fragmentation have less extensive e-democracy development than municipalities with lower levels of party competition.

No

\section{Resources}

(H8) Organizational Capacity Hypothesis: Municipalities with greater organizational capacity have more extensive e-democracy development than municipalities with smaller organizational capacity.

$\left(\mathrm{H}_{9}\right)$ Past Performance Hypothesis: Municipalities with better past performance in e-government have more extensive e-democracy development than municipalities with poorer past performance.

(Hı) ICT Portfolio Hypothesis: Municipalities with a BMA with ICT in its portfolio have more extensive e-democracy development than municipalities without such a function.

(H I I) Professional Network Hypothesis: Municipalities with leaders who are members of a professional network have more extensive e-democracy development than municipalities without persons with such a function. 


\section{NOTES}

${ }^{1}$ The number of municipalities declined in the years under study due to amalgamations. On January I ${ }^{\text {st }}$ of each year the number of municipalities in the Netherlands was respectively, $\mathrm{N}=443$ in $2007, \mathrm{~N}=443$ in 2008, N=44 I in 2009, $\mathrm{N}=43 \mathrm{I}$ in $20 \mathrm{I} 0, \mathrm{~N}=4 \mathrm{I} 8$ in $20 \mathrm{I} \mathrm{I}$.

${ }^{2}$ The turnout during municipal elections was $73.2 \%$ in $1986,62.3 \%$ in $1990,65.3 \%$ in $1994,58.9 \%$ in $1998,57.9 \%$ in $2002,58.6 \%$ in 2006 , and $54.1 \%$ in 2010 (The official election results for the local elections were taken from the database of the Dutch Electoral Council: http://www.verkiezingsuitslagen.nl/).

${ }^{3}$ The E-Governance Monitors of 2007 and 2009 are examined by Daadkracht in cooperation with TNS NIPO, and is commissioned by ICTU (program Overheid heeft Antwoord(C) / BZK). The E-Governance Monitor of 2008 is examined by Panteia and commissioned by ICTU (program Overheid heeft Antwoord(C) / BZK). The E-Governance Monitor of $20 \mathrm{I} O$ is examined by Daadkracht in cooperation with TNS NIPO, and is commissioned by ICTU (program RENOIR / BZK). In the last three months of every year researchers examined, using a standard questionnaire, the websites of all Dutch municipalities. Websites were monitored in the years I 999 to 20 I I, but for our study we only used the years between 2007 and $20 \mathrm{I}$ I.

${ }^{4}$ The number of municipalities declined in the years under study due to amalgamations. On January i ${ }^{\text {st }}$ of each year the number of municipalities in the Netherlands was respectively, $\mathrm{N}=443$ in $2007, \mathrm{~N}=443$ in $2008, \mathrm{~N}=44$ I in 2009 , $\mathrm{N}=43 \mathrm{I}$ in $20 \mathrm{I} 0, \mathrm{~N}=4 \mathrm{I} 8$ in $20 \mathrm{I} \mathrm{I}$.

${ }^{5}$ Items that we did not include in our e-democracy score are (I) service provision, (2) personalized service provision, and (3) accessibility standards, because these items reflect the e-service part of e-government.

${ }^{6}$ The full list of items is available only in Dutch from http://www.e-overheid.nl/onderwerpen/voortgang-enplanning/overheidnl-monitor/gemeenten (ICTU, I999-20 I I), but a translation of the full list of items is available on request from the first author.

${ }^{7}$ Local political parties that are possibly founded on the basis of Christian principles are not included.

${ }^{8}$ For the years 2007-2009 we used information from September 2006, and for the years 2010-20 I I we used information from August 20 I 0 . In both cases these data cover the composition of the BMA after local elections, that were respectively in March 2006 and March $20 \mathrm{I} 0$.

9 The information on the local elections of March 2002, March 2006, and March 2010 were retrieved from the website of Freek Ogink (nlverkiezingen.com; visited on 26-6-20 I 3). The main source of information for election results for both national and local elections in the Netherlands is the website of the Electoral Council (kiesraad.nl). However, these election results consider local political parties as one broad category, which makes it computationally impossible to calculate the correct differences for all political parties in a municipality between two election periods.

${ }^{10}$ For the construction of this variable we constructed a data set based on information from the VB Groep 'Tele Democracy. Research onto the Internet and local democracy (I996) (In Dutch:'Teledemocratie. Een onderzoek naar Internet en de lokale democratie.', Deloitte \& Touch 'Survey research digital town halls' (I 997-I999) (In Dutch 'Onderzoeksresultaten onderzoek digitale gemeentehuizen.'), and ICTU 'E-Government ranking municipalities' (2000-2003) (In Dutch: Overheid.nl monitor gemeenten). Based on this information however, we were unable to distinguish between the years 1997 and I 998. That is why our scale ranges between $\circ$ and 6 (7 possible scores) while the years in which websites were adopted range between 1996 and 2003 (eight possible years).

${ }^{11}$ See note 9 .

${ }^{12}$ The five Wadden Island municipalities Texel, Vlieland, Terschelling, Ameland and Schiermonnikoog were removed from our analyses. They proportionately have a lot of money and manpower for the maintenance of the island. 



\section{CHAPTER 5. LIFTING THE BAN ON DUTCH BROTHELS: DO LOCAL SOCIAL NEEDS AND LOCAL POLITICAL DEMANDS MATTER FOR MUNICIPAL PROSTITUTION POLICIES?'}

\section{ABSTRACT}

This article examines to what extent Dutch municipalities have adapted new local prostitution regulations to local needs and demands following the 2000 decentralization. We examined the extent to which a national template is locally adapted, and which factors inspired such adaptations. We found that many municipalities extensively copied the regulatory template developed by the Dutch Association of Municipalities. Our analyses show that - unexpectedly and contrary to popular arguments on the merits of decentralization - local needs and demands played no major role in explaining local policy-adaptations. Political fragmentation and size-related municipal resources however do explain differences in local adaptations.

\section{Background and research questions}

In the academic literature the idea is widespread that decentralization would provide "a fertile ground for innovation and experimentation" (Beetham, r996, p. 38; see also, Füglister, 20 I I; Karch, 2007a; Volden, 2006). Responding to a "diversity of situation and needs between different localities" (Beetham, i 996, p. 38) municipalities, on the basis of their knowledge of local conditions (genius of place) would tailor programs to local social needs and political demands, thereby contributing to increased policy effectiveness. In the politico-administrative world of "ministers and mandarins" (Pollitt \& Bouckaert, 2004, p. 87; Denters, 2005) rather similar arguments have provided the rationale for recent trends towards decentralization in many countries of the Western world.

The underlying assumption here is that subnational governments will use their discretion to develop new programs that fit specific local social needs and political demands and priorities. This paper asks whether municipalities do indeed adopt new programs that are geared to specific local conditions. Most studies of policy innovations in decentralized contexts do not tell us a great deal about this question because they typically focus on the timing of the introduction of new policies. ${ }^{\mathrm{I}}$ Following Rogers (2003, p. 5), innovation studies con-

\footnotetext{
${ }^{\mathrm{I}}$ Jans, W., Denters, B., Need, A., \& Van Gerven, M. (in press). Lifting the ban on Dutch brothels: Do local social needs and local political demands matter for municipal prostitution policies? Policy \& Politics.
} 
centrate on diffusion as "the process in which an innovation is communicated through certain channels over time among the members of a social system". Accordingly, many studies emphasize the timing of adoption (Berry and Berry 2007), but typically ignore the substantive component of innovations in local government. ${ }^{2}$ This is unfortunate, because it does not tell us much about possible substantive local adaptations in innovative programs in different jurisdictions (Glick \& Hays, I 99 I; Rogers, 2003). Although various scholars have argued for the need to look beyond the mere timing of innovations (Clark, I 985; Glick \& Hays, I 99 I; Mooney \& Lee, I 999), studies focusing on substantive adaptations are still rare (Karch, $2007 \mathrm{~b}$ ). This study aims to fill this gap by investigating how and to what extent local policymakers use their discretion to gear policies to local conditions.

In this publication we focus on the case of the decentralization of prostitution policies in the Netherlands in 2000 to study how Dutch municipalities used their increased powers to regulate the local prostitution industry. Our main question is to determine to what extent municipalities - after the decentralization - used their discretion to tailor their new policies to local social needs and political demands. In 2000 - after a heated, twenty-year controversy - a national law was enacted that lifted the national ban on brothels. Prior to this legislation, prostitution was prohibited in the Netherlands, but was condoned in many municipalities, as long as prostitution posed no threat to public order and sex entrepreneurs maintained a degree of discreetness (Outshoorn, 2004a). ${ }^{3}$ Up to 2000 various attempt to legalize prostitution were unsuccessful because of the veto-power of the ChristianDemocrats, who were represented in every Dutch cabinet since i 9 I 7 (Outshoorn, 2004a). The installation in 1997 of the first Dutch cabinet after the Great War without ChristianDemocratic participation provided a "window of opportunity" (Kingdon, 20 I 3 ) to adopt a more liberal prostitution law. This law made the Netherlands the first European country to legalize prostitution. The new legislation strictly distinguished voluntary prostitution, to be regulated as sex-work, from forced prostitution, to be prosecuted as illegal (Outshoorn, 2004 b). Sex-work, after its legalization, should allow for more effective regulation and control. At the same time strict regulation, controls and stringent rule-enforcement should curb the dark sides of the sex-industry (Savornin Lohman, Remme, \& Hillenaar, i 999a, p. го). The law therefore not only lifted the ban, but also provided the legal basis for the regulation of sex work. Responsibility for regulating the industry was assigned to municipalities.

The delegation of this responsibility to municipalities was based on the conviction that "municipalities are in the best position to conduct a policy on prostitution that matches the local situation” (Savornin Lohman et al., ı 999a, p. I4). This makes the Dutch decentralization of prostitution regulation an excellent case for the aim of this paper. In the context of this decentralization of prostitution policies, our twofold research question is: ( I) To what extent were there any differences in municipal by-laws after the Dutch decentralization, and (2) to what extent can we explain these differences by variations in local social needs, political demands and other factors? Our analyses will provide two indications about the way in 
which municipalities used their increased discretion after the decentralizations. Part one of our question will allow us to establish whether or not decentralization results in policy diversity. Part two of the question will also tell us to what extent any such diversity is the result of local social needs and local political demands.

\section{Theory and hypotheses}

In this publication we will use a simple rational choice model. We assume that actors (here municipalities), when faced with a choice between different courses of action, on the basis of available - but not necessarily full - information, will choose the best option available to them (Hedström, 2005, p. 6r). This implies that in their selection of policy-alternatives municipalities make a purposive choice, based on their interests, beliefs, and preferences. To derive specific hypotheses we start from a general expectation which states that: municipalities' inclination to innovate and adapt policies to local circumstances is stronger when they are (a) more strongly motivated to do so, when (b) they have no or only minor obstacles, and (c) when they command more resources (Berry \& Berry, 2007; Mohr, I 969).

\subsection{Motivation}

Municipalities' motivations to adapt the local by-law to local circumstances may arise from two distinct motivational factors. The first is based on the assumption that municipalities respond to local social needs and problems, and seek optimal solutions for these. The second motivational factor (political demands) is related to the ideological climate in a municipality. In this study we will consider two factors reflecting differences in social needs, and two factors pertaining to ideological differences.

Policymakers' motivation to adopt a new policy and adapt it to the local situation will be higher when there is a severe societal need or problem (Daley \& Garand, 2005; Karch \& Cravens, 20 I I Sapat, 2004). In this context this implies, first of all, that in municipalities where prostitution occurs, the lifting of the ban on brothels ensures there is a motivation for regulating prostitution in order to cope with local problems caused by the sex-industry. Hence, we expect that: Hypothesis I: Municipalities with prostitution make more adaptations to the local by-law than municipalities without prostitution.

The second needs-related factor pertains to criminal side effects of the sex-industry. Prostitution is associated with increased levels of crime, such as human trafficking (Outshoorn, 2004b), organized crime, drug abuse, and street violence. The higher overall, crime rates are, the more municipalities will be concerned about the potential negative effects of brothels on public safety, and the higher the perceived need for regulations. Hence, we hypothesize that: Hypothesis 2: Municipalities with a higher crime rate make more adaptations to the local by-law. 
Policies however are not only responses to local social needs and problems. Previous research has also shown that political ideologies matter for the adoption of innovative policies (Berry \& Berry, I 990; Boehmke \& Witmer, 2004). Therefore, we expect that the political party's position vis-à-vis the legalization of sex-work matters. If political parties in a municipality are against the legalization of prostitution, they will make stronger efforts to restrict prostitution, and will be keen to use local legislation to curb prostitution and its negative effects. Our third hypothesis reads: Hypothesis $3:$ Municipalities with stronger local political resistance make more adaptations to the local by-law.

Moreover, local public opinion may also be important, especially when moral issues (like prostitution) are at stake (Haider-Markel \& Meier, I 996; Jensen, 2003; Mooney \& Lee, 2000; Sluiter, 20I2). Previous studies have indicated that for such issues the prevalence of conservative religious beliefs in a jurisdiction may have a negative impact on the adoption of innovations, that is, in the case of lottery adoptions (Berry \& Berry, i 990; Pierce \& Miller, I 999). Although in general the Netherlands has a reputation for moral liberalism, there were particular localities with pockets of opposition to the legalization of prostitution. This opposition was concentrated in the so-called Bible Belt where we find large conservative Protestant congregations. These conservative Protestants are strongly opposed to moral liberalism, and to the liberal ways of Dutch life in general. We expect that when municipalities experience more pressure from these groups that more efforts are made to restrict prostitution. Therefore, we hypothesize: Hypothesis 4: Municipalities with stronger presence of conservative Protestants make more adaptations to the local by-law.

\subsection{Obstacles}

Numerous scholars have stated that a more fragmented and competitive political arena constrains the propensity to reform (Allen, 2005; Haider-Markel \& Meier, I 996; Mooney \& Lee, I 995). This is based on the presumption that when power is shared broadly across parties, it will be more difficult to build a winning coalition (Brooks, 2005). Therefore, we will concentrate on the political fragmentation of a municipality as a major obstacle for adopting changes in the local by-law. Our hypothesis thus reads: Hypothesis 5: Municipalities that are more politically fragmented make fewer adaptations to the local by-law.

\subsection{Resources}

The costs of implementing local policy changes can be considerable. Therefore, the amount of financial (the amount of revenues) and human resources (the amount and quality of staff) are important (Berry and Berry 2007; Rogers, 2003; Walker, I 969; Walker, Avellaneda, and 
Berry 20 I I). The availability of such resources is positively associated with the size of organizations. Therefore, we expect: Hypothesis 6: Municipalities that are larger in size will make more adaptations to the local by-law.

Moreover, following other scholars, we consider professional networks to be a major social resource. They create a setting where policy makers can acquire information on the latest developments, trends and standards, and a place where they have the opportunity to discuss many municipal level policy innovations (Balla, 200I; McNeal, Tolbert, Mossberger, \& Dotterweich, 2003). We would expect municipalities with leadership in a professional network to be more likely to be well informed, and therefore better equipped to make substantive changes. Hypothesis 7: Municipalities with leaders who are members of a professional network make more adaptations to the local by-law than other municipalities.

\section{Data and Operationalization}

\subsection{Research population}

Our research population comprises of all Dutch municipalities in 2000 ( $N=537)$. In October 2012 we send a written request (followed by a reminder, and a final personal contact early 20I3) to all then existing 4 I 5 Dutch municipalities to provide us with a copy of the text of the first published relevant by-law after the lifting of the brothel-ban. We also asked those municipalities that in between 2000-20 I 2 were involved in amalgamations to provide by-laws of municipalities that were merged into their jurisdiction. This resulted in a response rate of 6 i $\%(\mathrm{~N}=328$ out of $\mathrm{N}=537)$. Our sample is representative for the population of Dutch municipalities in 2000 in terms of geographical distribution, but there is a slight overrepresentation of medium-sized municipalities (20,000-50,000 inhabitants) at the expense of smaller municipalities (between 5,000-20,000 inhabitants). This is not a major concern, because in our analyses we take into account municipal size.

\subsection{Measurement of the dependent variable}

Our dependent variable is based on municipalities' relevant by-laws. To this aim we focused on the content of the prostitution chapter in their General Local Act (GLA; Algemene Plaatselijke Verordening). The GLA, which is present in all municipalities, collects all municipal provisions regarding public order and public safety. Municipalities that wanted to regulate brothels and sex-work through a system of permits for sex-establishments could do so by adding an optional prostitution chapter to their GLA (Leek \& van Montfort, 2004). However, municipalities (for example those without brothels) could also decide not to add such a chapter (Savornin Lohman et al., I 999a, p. 25). To assist municipalities, the Dutch Association of Municipalities (VNG; Vereniging van Nederlands Gemeenten) produced a 
draft for such a prostitution chapter (Savornin Lohman, Remme, \& Hillenaar, I 999b, pp. 5I2). In our analysis we compare local GLA prostitution chapters with this national VNGmodel.

As a first step, we compared the prostitution chapters of all municipal GLAs with the corresponding chapter in the model-GLA using the plagiarism detection software Ephorus (20I3). This software is ideally suited for our purposes, because it allows for a combination of quantitative and qualitative analyses. Quantitatively, Ephorus provides information in the form of overlap percentages. In addition, it also produces a wealth of qualitative information on similarities and differences in local policies. Most importantly, Ephorus provides an overview for each municipality; giving the text of the model-GLA and the text of the local GLA in parallel, showing (in different colors) identical sentences, sentences with minor changes, and unique sentences. In a second step, we coded all changes to the modelGLA. To indicate the type of adjustments municipalities made, and to code these adjustments, we used Atlas.ti (Version 7.0.80). Our coding scheme was based on previous research (Smallenbroek \& Smits, 200 I, p. 22) and comprised five codes reflecting editorial changes, and eight codes reflecting substantive changes. ${ }^{4}$ Editorial changes included (I) rewritten sentences without changing substantive content, (2) spelling errors, scanning errors, and different numbering of provisions, (3) opening hours, (4) regulations on the transitional phase, and (5) remaining editorial changes. The substantial adaptations consist ( I) additional licensing requirements, (2) enlarging options for closure brothels or repeal of permits, (3) maximum number of brothels, (4) locational requirements, (5) additional rules and regulations, (6) rules on exemptions, (7) changes in or added definitions, and (8) other substantive adaptations. In general the adaptations were coded by bullet-point or by sentence. The editorial adaptions were, if necessary, also coded by single words, because sometimes more than one editorial change could have been made per sentence. Our research question is about differences between municipalities in the total amount of (substantial) adaptations, and for that reason, in our analyses we are using an index of the eight substantial adaptations only. Because these eight dimensions have dissimilar ranges, and because we assume all dimensions to be equally important we calculate the substantive adaptations measure by condensing each item to a four category ordinal measure (no reform (o), I adaptation, 2 adaptations, and 3 or more adaptations), and then sum up these individual scores for each municipality. ${ }^{5}$ Hence, the variable ADAPT ATION has a theoretical range between $\circ$ and 24 .

\subsection{Measurements of the explanatory variables}

For the motivational factors we employ four different measures. The first variable measuring whether or not municipalities had PROSTITUTION within their territorial borders is a dichotomous variable, taking the value of $\mathrm{I}$ if a municipality is known to have prostitution, 
and $\circ$ if it is not. We use information collected in 1999 for a national report (Visser, Oomens, \& Boerman, 2000), which was based on mail-surveys among municipalities, police regions, and municipal health services about the occurrence of prostitution (sex-clubs, brothels, escort agencies, and home prostitution) in municipalities. In approximately $35 \%$ of the municipalities in our sample there had been prostitution.

The total number of suspects arrested per $\mathrm{s} \circ, 000$ inhabitants in each municipality in the year 2000 provides the CRIME rate. Information is taken from Statistics Netherlands (2000) and is based on a nationwide crime-registration system used by all 25 police-regions. The variable ranges between $\circ$ and i 99, and was log transformed to satisfy the linearity assumption. The transformed variable ranges between $\circ$ and 5.29.

We measure LOCAL POLITICAL RESIST ANCE by computing the percentage of local council seats occupied by political parties that - at the national level - voted against the new prostitution legislation on brothels. ${ }^{6}$ The variable was measured using data from local elections in I 998, and ranges between $\circ$ and $77.57 .{ }^{7}$ Data was obtained from the Electoral Council (Kiesraad) ( 1 998).

Table 1. Descriptive Statistics ( $\mathrm{N}=321)$

\begin{tabular}{|c|c|c|c|c|}
\hline Information for: & Mean & sd. & Min. & Max. \\
\hline \multicolumn{5}{|l|}{ Dependent Variable } \\
\hline ADAPTATION & 4.89 & 3.68 & 0.00 & 15.00 \\
\hline \multicolumn{5}{|l|}{ Motivation } \\
\hline PROSTITUTION & 0.35 & 0.48 & 0.00 & 1.00 \\
\hline CRIME & 77. I I & 30.60 & 0.00 & 199.00 \\
\hline LOCAL POLITICAL RESISTANCE & 26.54 & I I. 74 & 0.00 & 66.67 \\
\hline CONSERVATIVE PROTESTANT OPPOSITION & 0.15 & 0.36 & 0.00 & I.०० \\
\hline \multicolumn{5}{|l|}{ Obstacles } \\
\hline POLITICAL FRAGMENTATION & 4.82 & I.I 3 & 0.15 & 8.79 \\
\hline \multicolumn{5}{|l|}{ Resources } \\
\hline SIZE & $3424 \mathrm{I} .7 \mathrm{I}$ & 51530.56 & 1000.00 & 592673.00 \\
\hline NETWORK & 0.27 & 0.45 & 0.00 & 1.00 \\
\hline
\end{tabular}

CONSERV ATIVE PROTEST ANT OPPOSITION is a dummy variable measuring whether or not a municipality hosts one or more Restored Reformed Churches (Sonneveld, 2004). The Restored Reformed Church is a subgroup of the conservative Christian Churches (in Dutch known as bevindelijk gereformeerden) that was established in 2004 as a deposition against the merger of the Protestant Churches in the Netherlands, and is known for its strict confession of the Bible. The membership of this group is concentrated in the Dutch Bible Belt. ${ }^{8}$

POLITICAL FRAGMENTATION is measured by the Laakso-Taagepera index ( I 979), which calculates the effective number of political parties in a municipal council by 
taking into account their relative size. The higher the score, the more fragmented a municipal council is. Data ranges between 2.27 and 8.79, and comes from the website nlverkiezingen.com (own calculations). ${ }^{9}$

To measure municipal SIZE, we used the number of inhabitants in a municipality as provided by Statistics Netherlands (2000); this variable ranges between I 000 and 592,673. It was log transformed to decrease the influence of larger municipalities. The range of the transformed size measure lies between 6.9 I and i 3.29.

To measure leadership in a PROFESSIONAL NETWORK we created a dummy variable measuring whether ( $\mathrm{I}$ ) or not ( $\mathrm{O}$ ) a municipality has a representative on the board of a provincial department of the VNG. These VNG-departments represent municipal interests, but also inform municipalities about new developments and issues. Boards usually consist of mayors and aldermen, and occasionally councilors. Data were self-collected by means of a written request sent to each provincial department. Table i presents the means, standard deviations, and the range of the dependent variable and the independent variables. For easier interpretation, in our analyses we use mean-cantered and standardized scores for the interval variables.

\section{Analyses}

\subsection{Answering the descriptive research question}

We start by answering the descriptive part of our research question: ( I) To what extent were there any differences in municipal by-laws after the Dutch decentralisation? In Figure I, we report the percentage overlap between municipal GLAs and the model-GLA. This percentage indicates the degree of diversity in local by-laws. Figure 2 provides an overview of the frequency of various substantive changes, and Figure 3 presents the frequencies of the total number of substantive changes per municipality.

The overlap-percentages in Figure I are calculated by Ephorus based on a comparison of the local GLA and the model-GLA. For example, if $8 \circ$ out of $\mathrm{s} \circ 0$ words in a local-GLA-text are taken from the model-GLA, the overlap is $80 \%$. The first bar on the left side shows that there are two municipalities with a $15 \%$ overlap. We find only a few municipalities in the range of I 5-50\% overlap. Most municipalities have an overlap between 50-90\%. Our findings indicate that the number of local adaptations to the model-GLA is rather limited. However, this tells us nothing about the nature of these changes. Figure 2 provides information about the types of adaptations made. 


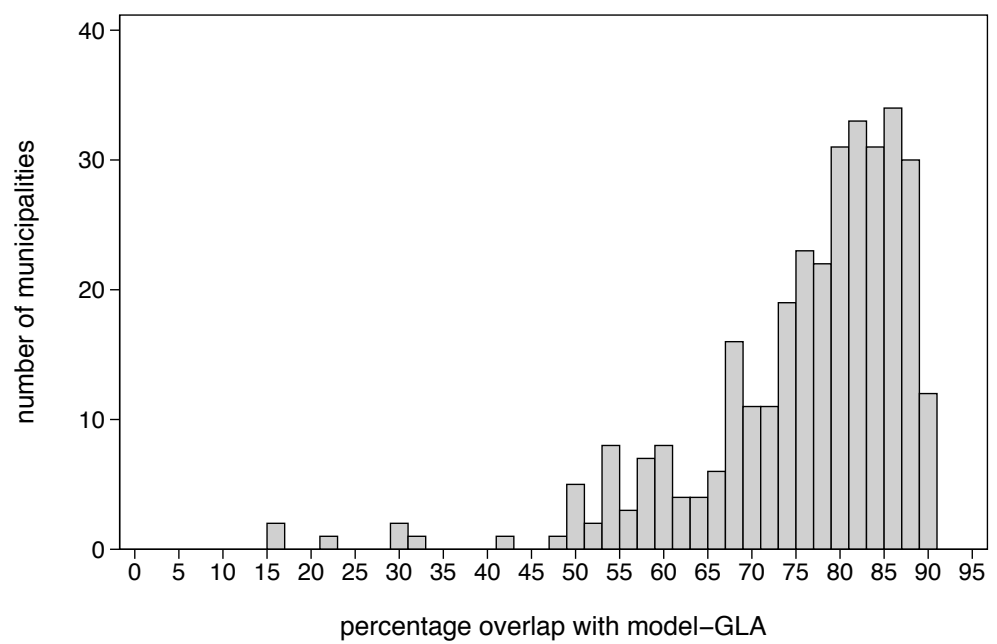

Figure 1. The distribution of the percentage overlap between the model-GLA and municipalities' own GLA $(\mathrm{N}=328)$.

Source: Self collected policy documents. Authors' own calculations.

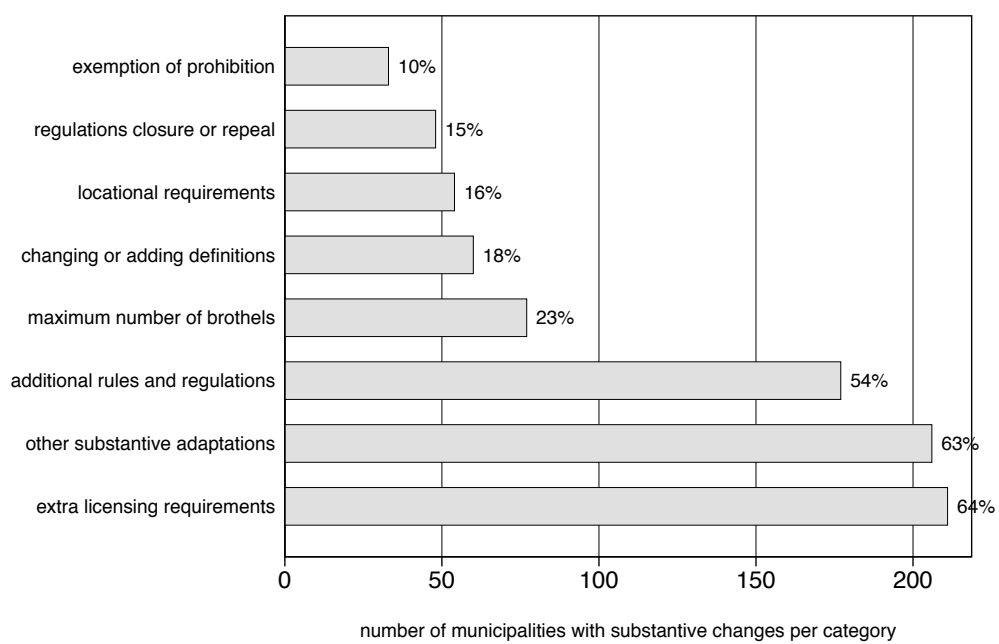

Figure 2. The absolute number of municipalities with substantive changes in each category $(\mathrm{N}=328)$.

Note: Percentages indicate how many municipalities have made changes in the relevant category Source: Self collected policy documents. Authors' own calculations. 
On average, municipalities made 90 changes to the model-GLA, but on average only 8.7 of these changes were substantive. These substantive modifications relate to eight possible categories (see paragraph 3.2). The top bar (exemption of prohibition) of Figure 2 shows that I \% $(\mathrm{N}=33)$ of the municipalities made adaptations in this category. In these cases it is explicitly mentioned that there is a total ban on brothels unless an authorized body (mayor/aldermen/council) grants an exemption. Moreover, I $5 \%(\mathrm{~N}=48)$ of the municipalities made adaptations to the regulations on closure and repeal of permits. These adaptations extend the options for temporary closure in case of rule-violations. Another I6\% ( $\mathrm{N}=54)$ of the municipalities adapted the model-GLA to specify locational requirements (mostly adding spatial constraints on the locations where brothels could be established). In I $8 \%$ ( $\mathrm{N}=60$ ) of the local GLAs, definitions were either changed or added to the model-GLA. This means that the local-GLA contains definitions that are either modifications of or additions to those provided by the model-GLA. Almost one in every four municipalities (23\%; N=77) made changes relating to the permitted number of brothels. In most cases this means allowing only a maximum number of brothels; sometimes even zero. More than half of the municipalities ( $54 \%$; N= I 77) specified additional rules. In most cases these new rules expanded options for surveillance and control of brothels, a ban on window prostitution, and provisions for prostitution on vessels. In nearly two-thirds of the municipalities (64\%; N=2 I I) extra-rules concerning licenses for brothels were added. In most cases these rules pertained to the number of employees in sex-establishments, a corporate parking space, or demanding a cadastral map of the location of the brothel. Finally, the second to last row (other substantive adaptations) shows that $63 \%(\mathrm{~N}=206)$ of the municipalities made adaptations that we could not classify in one of the main categories. These adaptations were exceptional, and meant for example that a license is only valid for a fixed term (for example i 2 months, or 5 years). Other changes in this category include; a ban on the provision of contraceptives in public, a prohibition on using the name of God for cursing in public, or specifying procedures for an application for a license.

In general we may conclude that municipalities primarily used their regulatory powers to curb the permissiveness of national legislation. Municipal adaptations to the VNG-model in most cases implied further restrictions. Now that we know the nature of the modifications, and by how many municipalities these were made, it is important to know the differences in the amount of substantive changes made by municipalities. Figure 3 is based on the total number of substantive changes that municipalities made to the model-GLA. First, we see that some 50 municipalities ( $5 \%$ ) made no substantive changes at all. About twenty percent of the municipalities $(\mathrm{N}=65)$ made only one or two substantive modifications. Then there is a large group of municipalities (58\%) that made between 3 - 10 substantive adaptations, and a smaller group of municipalities $(7 \%)$ making more than ten substantive modifications.

Overall, the results with regard to question ( $\mathrm{I}$ ) demonstrate that municipalities use their new discretion only to a limited extent. There is considerable overlap in municipal prostitu- 
tion by-laws. This uniformity was facilitated by the availability of a national template (the model-GLA provided by the VNG). At the same time, notwithstanding considerable overlap, we also find important variations in municipal regulations. Municipalities have made major substantive changes to the VNG-template aimed at curbing the local impact of the legalization of prostitution. In the next section we will test potential explanations for these differences.

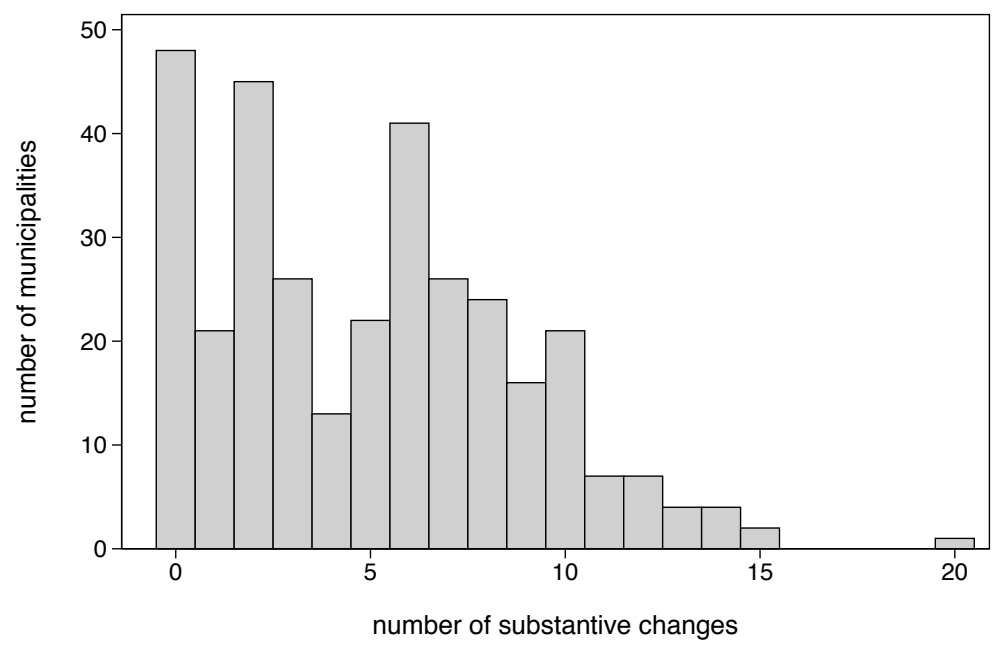

Figure 3. Municipalities' distribution of the number of substantive changes that are made $(\mathrm{N}=328)$.

Source: Self collected policy documents. Authors' own calculations.

\subsection{Answering the explanatory research question}

Now we will answer the second part of our research question: (2) To what extent can we explain these differences by variations in local social needs, political demands and other factors? We have analyzed our hypotheses in five steps (see Table 2). Our dependent variable measures the number of adaptations, and therefore a regression method from the Poisson distribution family, would have been appropriate (Long \& Freese, 2006). Because the underlying equi-dispersion assumption (mean equals variance) did not hold we did not use a Poisson Regression Model (PRM), but preferred a Negative Binomial Regression Model (NBRM; Long \& Freese, 2006). The NBRM-parameters were estimated using Stata/IC I 3. I. An analysis of regression diagnostics revealed only some minor problems. ${ }^{\text {Io }}$

In model $\mathrm{I}$ in Table 2 we examine the association between motivational factors and the dependent variable. In the second and third model we do the same for the influence of ob- 
stacles and resources. Subsequently, model 4 provides a simultaneous test for the influence of motivation, obstacles and resources variables. The negative binomial regression coefficients require an exponential transformation to determine the magnitude of their effects on the dependent variable. The coefficients are interpreted that - holding the other variables constant at their mean values (interval), or lowest values (dichotomous) - for a one-unit change in $x$ (or moving from $\circ$ to I for dichotomous variables) the expected number of substantive adaptations to the model-GLA changes by a factor of $\exp (\beta)$. This number allows for the calculation of the percent change, which might also be informative.

Model $\mathrm{I}$ in Table 2 presents the negative binomial regression results of the motivational variables. We expected that municipalities that were highly motivated would make more adaptations to the model-GLA. The coefficient of the prostitution variable is positive, in the expected direction, and statistically different from zero ( $\mathrm{p}=. \circ \mathrm{I} 6)$. For municipalities with prostitution, the expected number of adaptations changes by a factor of $\mathrm{I} .25(\exp (.225))$, or approximately $25 \%$. This means, at least provisionally, that hypothesis I is confirmed. For hypothesis 2, we find that the crime rate variable is positive as expected, but it is not statistically significant ( $p=.28 \mathrm{I}$ ). The coefficient of the political resistance variable is negative and statistically different from zero $(p=.04 \mathrm{I})$. Contrary to our expectations in hypothesis 3 , the negative sign indicates that municipalities where opposition to prostitution is stronger make fewer adaptations to the model-GLA. Finally, hypothesis 4 about the effect of conservative protestant opposition is provisionally refuted, because it failed to attain statistical significance $(p=$. I 43$)$.

Model 2 in Table 2 shows the negative binomial regression results of the obstacle variable. Our expectation was that more political fragmentation would lead to fewer adaptations to the model-GLA. The coefficient is in the expected direction, but is not statistically different from zero at convenient levels of significance $(p=.356)$. This implies for now that we found no confirmation for hypothesis 5 .

In model 3 in Table 2 we find the regression coefficients of the resources variables. We assumed municipalities with access to more resources would make more adaptations to the model-GLA. The positive size-coefficient does attain a conventional level of statistical significance $(p=.00 \mathrm{I})$, and shows that as expected human resources and financial resources are related to the number of adaptations municipalities make. A one-unit change in size (because we use standardized interval variables in our analysis this corresponds to one standard deviation) increases the expected number of substantive changes by a factor of I.I 5 $(\exp (.140))$, or by about $15 \%$. This means that for this moment we confirm hypothesis 6 . The network coefficient is also positive and statistically different from zero ( $p=.097)$, which offers an initial confirmation of hypothesis 7 . The effect shows that having a representative in the leadership of a Provincial VNG Department increases the expected number of adaptations with a factor of I. I 5 (exp(. I 4 I )), or with just about I 5 percent. 
Table 2. Negative Binomial Regression coefficients explaining the number of GLA adaptations $(\mathrm{N}=321)$.

\begin{tabular}{|c|c|c|c|c|}
\hline & $\begin{array}{l}\text { Model I } \\
\text { Coeff./se }\end{array}$ & $\begin{array}{l}\text { Model } 2 \\
\text { Coeff./se }\end{array}$ & $\begin{array}{l}\text { Model } 3 \\
\text { Coeff./se }\end{array}$ & $\begin{array}{c}\text { Model } 4 \\
\text { Coeff./se }\end{array}$ \\
\hline \multicolumn{5}{|l|}{ Motivation } \\
\hline \multirow[t]{2}{*}{ PROSTITUTION } & $0.225^{* *}$ & & & 0.065 \\
\hline & $(0.105)$ & & & $(0.115)$ \\
\hline \multirow{2}{*}{ CRIME } & 0.027 & & & -0.017 \\
\hline & $(0.047)$ & & & $(0.053)$ \\
\hline \multirow[t]{2}{*}{ LOCAL POLITICAL RESISTANCE } & $-0.085^{*}$ & & & $-0.072^{+}$ \\
\hline & $(0.049)$ & & & $(0.050)$ \\
\hline CONSERVATIVE PROTESTANT & -0.145 & & & $-0.213^{+}$ \\
\hline OPPOSITION & $(0.136)$ & & & $(0.140)$ \\
\hline \multicolumn{5}{|l|}{ Obstacles } \\
\hline \multirow[t]{2}{*}{ POLITICAL FRAGMENTATION } & & -0.017 & & $-0.134^{* *}$ \\
\hline & & $(0.047)$ & & $(0.054)$ \\
\hline \multicolumn{5}{|l|}{ Resources } \\
\hline \multirow[t]{2}{*}{ SIZE } & & & $0.140^{* *}$ & $0.193^{* *}$ \\
\hline & & & $(0.047)$ & $(0.072)$ \\
\hline \multirow[t]{2}{*}{ NETWORK } & & & $0.14 \mathrm{I}^{+}$ & 0.120 \\
\hline & & & $(0.1 \circ 9)$ & $(0.1 \circ 8)$ \\
\hline \multirow[t]{2}{*}{ Constant } & г. 6 I $6^{* *}$ & $1.588^{* *}$ & $1.534^{* *}$ & $1.536^{* *}$ \\
\hline & $(0.064)$ & $(0.048)$ & $(0.056)$ & $(0.075)$ \\
\hline Loglikelihood & -841.520 & -848.147 & -841.162 & -834.976 \\
\hline AIC & I 695.040 & I 702.295 & 1690.325 & I 687.953 \\
\hline $\mathrm{N}$ & $32 \mathrm{I}$ & $32 \mathrm{I}$ & $32 \mathrm{I}$ & $32 \mathrm{I}$ \\
\hline
\end{tabular}

** $\mathrm{p}<0.0 \mathrm{I},{ }^{*} \mathrm{p}<0.05,{ }^{+} \mathrm{p}<0 . \mathrm{I}$ : one-tailed.

Note I: Estimated coefficients with standard errors in parentheses beneath.

Note II: Interval variables are centred around their mean values, and after that standardized for purposes of interpretation.

Model 4 in Table 2 tests for the simultaneous effects of motivation, obstacles, and resources. Combining these effects into one model did slightly change the outcomes and results described earlier. Our first four hypotheses pertain to motivational factors; all these hypotheses are refuted in the combined model. The coefficient of the prostitution variable, different from model I, after controls for the other variables in the model no longer leads to more adaptations ( $p=.288)$. This implies that hypothesis I is now refuted. Just like the initial results, in model $\mathrm{I}$, the variable crime again failed to attain the necessary level of statistical significance $(p=.375)$. Hypothesis 2 is therefore definitely refuted. Local political resistance against the lifting of the brothel ban is related to the amount of customization of the policy template $\left(p=.0^{\circ}\right)$, but considering its negative sign it is contradicting what we expected. We therefore also conclude that hypothesis 3 (stating that municipalities will make more adaptations the fiercer political opposition to the legalization of prostitution) is refuted. 
Likewise, the presence of strong conservative Protestant opposition - contrary to our expectations as expressed in hypothesis 4 - does not lead to more amendments to the model-GLA. In the final model there is even a statistically significant negative effect ( $p=.063$ ). Political fragmentation does indeed constitute an obstacle for the acceptance of local adaptations to the model-GLA. The effect of this variable, after controls for other variables, is now highly significant and its negative sign points in the predicted direction $(\mathrm{p}=.006)$. The size of the effect means that a one-unit increase ( 1 SD) in political fragmentation is associated with a decrease in customizations by a factor of 1.067 (exp(-.134)), or approximately 7 percent. This confirms hypothesis 5 , stating that more political fragmentation leads to fewer customizations. Municipal size is again positively related to adaptations, and this effects is statistically significant $(\mathrm{p}=.003$ ). The effect changed slightly, and a one-unit ( I SD) increase in size is now associated with an increase in a municipalities' mean adaptation score by a factor of I.2 I (exp(. I 93)), or around 2 I \%, compared with a factor increase of I.I 5 , and approximately $15 \%$ in model 3 . This provides support for hypothesis 6 , which implies that larger, more resourceful municipalities are making more adaptations to the model-GLA then are smaller municipalities. Finally, after controls for the other factors, the network variable (hypothesis 7 ) is no longer statistical significant ( $p=.133$ ), and leadership representation in a professional network thus seems to be unrelated to the number of modifications municipalities made to the model-GLA.

All together, the results with regard to question (2) demonstrate that differences in the degree to which municipalities amended their local GLA did neither increase with higher social needs and more serious local problems, nor did they rise with higher local demands for more stringent regulation of brothels. The limited changes we did find (see paragraph 4.r), were not - as popular arguments in favor of decentralization would have it - the result of variations in local social needs and political demands. Rather, the obstacles municipalities faced, and their availability of resources caused these changes. In the discussion we will consider these unexpected findings.

\section{Conclusion and Discussion}

Popular arguments, both in the academic literature and in the politico-administrative world, imply that decentralization of policies to regional and local governments might lead to more effective policies, because subnational governments would be well-placed to adapt policies to local social needs and local political demands. In this contribution we have considered the case of the decentralization of prostitution policies to Dutch municipalities in 2000. In this context we asked a twofold research question. With regard to the first of these questions ( I) to what extent were there any differences in municipal by-laws after the Dutch decentralization - we found a considerable degree of uniformity in the post-decentralization policies that were adopted by municipalities. On the basis of a quantitative and qualitative 
content analysis - using anti-plagiarism software Ephorus and software for qualitative analysis Atlas.ti - of the relevant by-laws of 328 (6r\% of 537) Dutch municipalities, we found striking similarities in the newly adopted regulations. Rather than autonomously developing their own local by-law, municipalities widely used a model provided by the Dutch Association of Municipalities (VNG) as a template. Local adaptations to this template were made, but most of these changes proved to be editorial and linguistic, rather than substantive. On average, less than ten percent of these changes proved to be substantive. Although quantitatively limited, these changes were oftentimes substantively important and typically aimed at curbing the local impact of the legalization of prostitution. Also, Figures 2 and 3 demonstrated definite variation among municipalities in the amount adaptations they made to the policy template.

Our second question - (2) to what extent can we explain these differences by variations in local social needs, political demands and other factors - was aimed at finding out to what extent such substantive policy differences between municipal by-laws were the result of local social needs and local political demands. Our analyses unexpectedly showed that the extent to which municipalities made local adaptations did neither increase with higher local needs (presence of prostitution and higher local crime rates) nor with stronger local political opposition (stronger conservative protestant opposition against prostitution and stronger local political resistance against the new law) against liberalization of prostitution policies. Rather, local customizations of the policy template were affected by the amount of obstacles and resources. Politically fragmented municipalities adapted less than did municipalities with strong party leadership, and municipalities with larger availability of financial and personnel resources adapted more to the provided policy template.

Interpretation of these findings is not immediately straightforward. On the basis of our theories of decentralization and our simple rational choice model we would expect that policy choices made by municipalities would be affected by political motivations; either based on a political desire to solve local social problems, or to shape policies in line with ideological preferences (that is, opposition to liberalization of prostitution policies). However, our findings do not substantiate such expectations. Rather, our findings suggest an alternative interpretation of policy-making. Instead of making difficult controversial choices, policymakers may be risk-averse (Denters, Van Heffen, \& De Jong, i 999; DiMaggio \& Powell, I 99I; Van der Veer, 20 I3) and might tend to blame-avoidance (Brooks, 2005; Weaver, I 986). Both these inclinations might lead local policy-makers to copy previously established standards developed by others rather than developing policies autonomously. This interpretation is supported by some of our findings. First, we find that all municipalities included a prostitution chapter in their local GLA even though there was as yet no local prostitution problem. Moreover we also find, quite unexpectedly, that in the light of strong political opposition to a liberalization of prostitution policies, we do not see an increased likelihood of 
adapting the national VNG-model to curb prostitution by imposing stricter rules, but we actually find the exact opposite. In cases of strong local opposition municipalities are actually less likely to deviate from the nationally provided VNG-standards. This suggests that in the light of such opposition, policy-makers are inclined to stick closely to widely accepted and therefore easier to legitimate informal rules and guidelines developed by others, rather than autonomously developing a local alternative. The negative effect of political fragmentation points in the same direction. In case of a fragmented political landscape it is easier to adopt the generally accepted VNG-standard than any locally developed policy.

There are also more policy specific considerations that may explain our unexpected findings. As Outshoorn (2004a) has shown, the policy-process leading to the ultimate decision about the Dutch legalization of prostitution in 2000 was characterized by depoliticisation and pragmatism. In such a context it is likely that (local) policy-makers may be inclined to renounce discretion, 'pass the buck' to bureaucrats and resort to authoritative outside standards (Weaver, I986). Moreover in this depoliticized context, it is not surprising that technical constraints in the form of obstacles and resources rather than political motivations determine the results of local policy-making.

In our analysis of the prostitution policies of Dutch municipalities we have experimented with the use of the Ephorus plagiarism program. This program is especially useful for comparing large numbers of policy documents to a main document. ${ }^{\text {II }}$ This main document might be a nationally provided template or model (as in this study), but it might also be a policy document prepared by an early adopter - to compare it with subsequent documents produced by other jurisdiction to investigate horizontal (local government to local government) copy and customization behavior. Ephorus is particularly useful, because it produces both quantitative and qualitative information. The quantitative information might be used directly as a variable in the analyses, but in order to distinguish between substantive and merely editorial and linguistic differences between documents, it needs to be complemented with a qualitative content analysis. As such, this instrument holds promises for content oriented analysis of policy innovations.

In this study we have not only contributed to the literature by analyzing whether municipalities, after a decentralization, used their newly obtained discretion to adopt innovative policies geared to local conditions. We have also made a contribution to the study of policy innovations by moving beyond an analysis of the timing of innovations. So far there are only a limited number of studies that have focused on the content of innovations (Clark, I 985; Glick \& Hays, I 99 I; see also, Karch, 2007b). Finally, local governments developing tailormade innovations are fundamental to decentralized governmental systems. Uncovering factors that account for differences in (local) governments' ability and willingness to customize policies is important in understanding the consequences of national governments' 
devolution decisions. The approach taken in this study might also be applicable to other political systems, and to other policy settings. 


\section{CHAPTER FIVE}

\section{REFERENCES}

Allen, M. D. (2005). Laying Down the Law? Interest Group Influence on State Adoption of Animal Cruelty Felony Laws. Policy Studies Journal, 33(3), 443-457. doi: I 0. I I I I/j. I 54 I-0072.2005.00 I 24.X

Balla, S. J. (200 I). Interstate Professional Associations and the Diffusion of Policy Innovations. American Politics Research, 29(3), 22 I-245. doi: I 0.1 I 77/1 532673 X0 I 29300 I

Beetham, D. ( 1 996). Theorising democracy and local government. In D. King \& G. Stoker (Eds.), Rethinking local democracy (pp. 28-49). London: Macmillan.

Berry, F. S., \& Berry, W. D. ( г 990). State lottery adoptions as policy innovations: An event history analysis. American Political Science Review, 84(2), 395-4 I 5 .

Berry, F. S., \& Berry, W. D. (2007). Innovation and diffusion models in policy research. In P. A. Sabatier (Ed.), Theories of the Policy Process (second., pp. 223-260). Boulder, CO: Westview Press.

Boehmke, F. J., \& Witmer, R. (2004). Disentangling diffusion: The effects of social learning and economic competition on State policy innovation and expansion. Political Research Quarterly, 57 ( I), 39-5 I. doi: I 0. I I 77/1 106591 290405700104

Brooks, S. M. (2005). Interdependent and domestic foundations of policy change: The diffusion of pension privatization around the world. International Studies Quarterly, 49(2), 273-294.

Clark, J. ( I 985 ). Policy diffusion and program scope: Research directions. Publius, 15 (4), 6 I-70.

Daley, D. M., \& Garand, J. C. (2005). Horizontal diffusion, vertical diffusion, and internal pressure in state environmental policymaking, I 989-1 998. American Politics Research, 33(5), 6 I 5-644. doi: I O. I I 77/1 $532673 \times 042734$ I 6

Denters, B. (2005). Towards local governance? In B. Denters \& L. E. Rose (Eds.), Comparing local governance: Trends and developments (pp. 246-262). New York, NY: Palgrave Macmillan.

Denters, B., Van Heffen, O., \& De Jong, H. M. ( 1999$)$. Proeftuin of procrustesbed? Gemeentelijk jeugd- en veiligheidsbeleid in het kader van het grote-stedenbeleid, I 995-I 997. Bestuurskunde, 3, I 06 -I I 5 .

DiMaggio, P. J., \& Powell, W. W. ( I 99 I). The iron cage revisited: Institutional isomorphism and collective rationality in organizational fields. In W. W. Powell \& P. J. DiMaggio (Eds.), The new institutionalism in organizational analysis (pp. 63-82). The University of Chicago Press.

Ephorus. (2013). Ephorus: Plagiarism prevention. Retrieved from https://www.ephorus.com/

Füglister, K. (20 I I). Cantons as Policy Laboratories of the Federal State? The Diffusion of Health Insurance Subsidy Policies among the Swiss Cantons. (Doctoral Dissertation) University of Zürich.

Glick, H. R., \& Hays, S. P. ( I 99 I ). Innovation and reinvention in state policymaking: Theory and the evolution of living will laws. The Journal of Politics, $53(03), 835-850$.

Haider-Markel, D. P., \& Meier, J. ( I 996). The Politics of Gay and Lesbian rights: Expanding the Scope of the Conflict. The Journal of Politics, $58(2), 332-349$.

Hedström, P. (2005). Dissecting the social: On the principles of analytical sociology. Cambridge University Press Cambridge.

Jensen, J. L. (2003). Policy Diffusion through Institutional Legitimation: State Lotteries. Journal of Public Administration Research and Theory, I 3(4), 52 I-54 I. doi: I 0. I 093/jopart/mug०33

Karch, A. (2007a). Democratic Laboratories. Policy diffusion among the American states. Ann Arbor: The University of Michigan Press.

Karch, A. (2007b). Emerging Issues and Future Directions in State Policy Diffusion Research. State Politics E Policy Quarterly, 7(I), 54-80. doi:10.1 I 77/I 532440007007001 04

Karch, A., \& Cravens, M. (20 I I). Policy Diffusion, Program Content, and Post-Adoption Reform: The Adoption and Modification of Three Strikes Laws. Annual conference on State politics and public policy. Hanover, NH.

Kiesraad. (1 998). Election Results. [In Dutch:Verkiezingsuitslagen] [Data file]. Retrieved from http://www.verkiezingsuitslagen.nl/Na I 9 i 8/Verkiezingsuitslagen.aspx/

Kingdon, J. W. (20 I 3). Agendas, alternatives, and public policies (2nd ed.). Harlow, United Kingdom: Pearson Education Limited.

Laakso, M., \& Taagepera, R. ( I 979). The "effective” number of parties: "A measure with application to West Europe." Comparative Political Studies, I 2 ( I), 3 . 
Leek, J., \& Van Montfort, A. (2004). Convenient Local Policymaking for Inconvenient Issues? The Establishment of Brothels in the Netherlands. Society and Economy, 26(2-3), 2-3.

Long, J. S., \& Freese, J. (2006). Regression models for categorical dependent variables using Stata. Stata press.

McNeal, R. S., Tolbert, C. J., Mossberger, K., \& Dotterweich, L. J. (2003). Innovating in digital government in the American states. Social Science Quarterly, $84(\mathrm{I}), 52-70$.

Mohr, L. B. ( I 969). Determinants of innovation in organizations. The American Political Science Review, 63 ( I), I I II 26.

Mooney, C. Z., \& Lee, M.-H. ( I 995). Legislating Morality in the American States - the Case of Pre-Roe Abortion Regulation Reform. American Journal of Political Science, 39(3), 599-627.

Mooney, C. Z., \& Lee, M.-H. ( I 999). Morality policy reinvention: State death penalties. The Annals of the American Academy of Political and Social Science, 566(I), 80-92.

Mooney, C. Z., \& Lee, M.-H. (2000). The Influence of Values on Consensus and Contentious Morality Policy: U.S. Death Penalty Reform, i 956-82. The Journal of Politics, 62(I ), 223-239.

Outshoorn, J. (2004a). Pragmatism in the Polder: Changing Prostitution Policy in The Netherlands. Journal of Contemporary European Studies, I 2(2), I 65-I 76. doi: I 0. I $080 /$ I 460846042000250873

Outshoorn, J. (2004b). Voluntary and forced prostitution: the "realistic approach" of the Netherlands. In J. Outshoorn (Ed.), The politics of prostitution (pp. I 85-204). Cambridge University Press.

Pierce, P. A., \& Miller, D. E. ( I 999). Variations in the Diffusion of State Lottery Adoptions : How Revenue Dedication Changes Morality Politics. Policy Studies Journal, 27(4), 696-706.

Pollitt, C., \& Bouckaert, G. (2004). Public management reform: a comparative analysis (2nd ed.). New York, NY: Oxford University Press.

Rogers, E. M. (2003). Diffusion of innovations (5th ed.). New York: Free Press.

Sapat, A. (2004). Devolution and innovation: The adoption of state environmental policy innovations by administrative agencies. Public Administration Review, 64(2), I 4 I - I 5 I. doi: I o. I I I I/j. I 540-62 I 0.2004.00356.x

Savornin Lohman, P. M. de, Remme, H. W. G., \& Hillenaar, W. A. G. ( I 999a). Handboek lokaal prostitutiebeleid. Deel I. De opheffing van het algemeen bordeelverbod. The Hague, The Netherlands: VNG Uitgeverij.

Savornin Lohman, P. M. de, Remme, H. W. G., \& Hillenaar, W. A. G. ( I 999b). Handboek lokaal prostitutiebeleid. Deel IV. Instrumenten. The Hague, The Netherlands: VNG Uitgeverij.

Sluiter, R. (20 I 2). The diffusion of morality policies among Western European countries between I 960 and $2010: A$ Comparison of temporal and spatial diffusion patterns of six morality and eleven non-morality policies. (Doctoral Dissertation) Radboud University Nijmegen.

Smallenbroek, A. J. H., \& Smits, E. C. M. (200I). Gemeentelijk prostitutiebeleid na opheffing van het algemeen bordeelverbod. Inventarisatie van de stand van zaken. Den Haag.

Sonneveld, J. (2004). Inventory of Dutch places of worship. [In Dutch: Inventarisatie kerkelijke gebouwen Nederland (IKGN)]. November 2004 edition. Retrieved from http://www.hdc.vu.nl/nl/online-informatie/ikgn/

Statistics Netherlands. (2000). The Netherlands regional. [In Dutch: Nederland regionaal] [Data file]. Retrieved from http://www.statline.cbs.nl/

Van der Veer, J. C. V. (20 I 3). Weg uit het verleden: Een institutionele analyse van de gemeentelijke uitwerking van de Wet maatschappelijke ondersteuning (Wmo). (Doctoral Dissertation) VU University Amsterdam.

Visser, J. H., Oomens, H. C. D. M., \& Boerman, F. A. (2000). Prostitutie in Nederland in I 999: de nulmeting, een jaar voor de invoering van de wet die de opheffing van het algemene bordeelverbod regelt. Mr. A. de Graaf Stichting.

Volden, C. (2006). States as policy laboratories: Emulating success in the children's health insurance program. American Journal of Political Science, $50(2), 294-3$ I 2.

Walker, J. L. (1 969). Diffusion of innovations among American States. American Political Science Review, 63(3), 880899.

Walker, R. M., Avellaneda, C. N., \& Berry, F. S. (20 I I). Exploring the diffusion of innovation among high and low

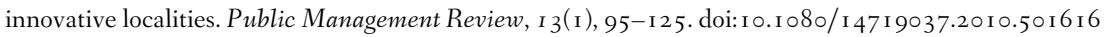

Weaver, R. K. ( I 986). The Politics of Blame Avoidance. Journal of Public Policy, 6(04), 37 I-398. 


\section{CHAPTER FIVE}

\section{NOTES}

${ }^{1}$ It should be noted that we define an innovation simply as a policy that is new to the particular municipality adopting it, no matter how many other municipalities may have already adopted it (compare, Walker, I 969, pp. 88 I).

${ }^{2}$ For an extensive overview of studies focusing on the timing of the adoption of innovations, see the appendix accompanying Berry and Berry (2007).

${ }^{3}$ For a comprehensive historical overview of the changing landscape of prostitution legislation in the Netherlands, see Outshoorn (2004a).

${ }^{4}$ The coding scheme was tested and retested by two researchers. One researcher did the coding.

${ }^{5}$ To test for the construct validity and unidimensionality of our index measure we performed a confirmatory factor analysis (CFA) with the principal component (PA) extraction method. We were able to confirm the one construct (factor) we were looking for. The eigenvalue was above 2.4 , and the communalities of the eight single items were all above $0.3 \circ$ except for two (which were 0.290 and 0.220 ), but these two items make good sense in terms of substantive interpretations and are therefore also included in our index. The test for the internal reliability of our index resulted in a Cronbach's alpha $(\alpha)$ of 0.650 , which is satisfactory.

${ }^{6}$ The political parties that voted against the proposal for the lifting of the brothel ban were the Reformed Protestant Party (SGP), the Christian-Democrats (CDA), the Reformatory Political Federation (RPF), and the Reformed Political League (GPV).

${ }^{7}$ Local elections were held in March I 998. The percentage is based on the number of votes for each party in each municipality.

${ }^{8}$ Although the group was only established in 2004 , we consider this measure as adequate because the population share of this group of conservative Christians is very stable over time.

9 The information on the local elections of March r 998 are retrieved from the website of Freek Ogink (nlverkiezingen.com; visited on 26-6-2013). The main source of information when it comes to election results for both national, and local elections is the website (kiesraad.nl) of the Electoral Council. Unfortunately, the election results of I 998 only contain the number of votes, and not the number of seats. Therefore, we had to rely on another source. If possible the data of Ogink were checked against the data of the Electoral Council, and against the Netherlands national news agency (ANP; Algemeen Nederlands Persbureau). For some municipalities values were missing $(\mathrm{N}=39)$. Because most missing values were due to amalgamation we were able to find election results from one year earlier ( I 997; $\mathrm{N}=\mathrm{I}$ o), or one year later ( I 999; $\mathrm{N}=29$ ).

${ }^{10}$ First, we removed seven influential cases from our analysis. The municipalities Almelo, Asten, Korendijk, Urk, Vlieland, Voorburg, and Warmond were removed. Second, the dependence of observations (correlated errors) nor multicollinearity posed any problems. Third, other assumptions that are very common to be diagnosed in linear regression analyses (OLS), such as the normality of residuals, the homoscedasticity of residuals, and linearity are not assumed for negative binomial regression models (NBRM).

${ }^{11}$ Of course the documents will have to be written in the same language. This restricts the usefulness of this software. But for an analysis of subnational governments in a monolingual setting (country, province, state) this tool can be useful. 


\section{CHAPTER 6. CONCLUSION AND DISCUSSION}

\section{Introduction}

In this dissertation, the aim was to describe and explain differences among Dutch municipalities in their execution of innovative decentralized policy responsibilities. We wanted to examine the validity of the decentralization-thesis - that in the development of local policies, local governments are responsive to local priorities, and to local needs and demands of their citizens. The alternative hypothesis concerns an absence of local responsiveness and local customization of policies because municipalities are not able to innovate according to their motivations due to existing obstacles and a lack of resources. In Table 3 in Chapter I we formulated the expectation that the particular relevance of especially motivations and resources is dependent on the type of policy that is under consideration. In this chapter we reflect on this expectation.

Differences in innovativeness among municipalities can become visible either through differences in timing of adoption of the innovation (Berry \& Berry, I990, 2007), or through differences in the content of the innovation (Clark, 1985; Karch, 2007a). We examined administrative and political innovations that were either mandated or voluntary. In four empirical chapters we tested hypotheses about the effects of municipalities' motivations, obstacles and resources on innovation (Berry \& Berry, 2007, 20 I 4; Mohr, I 969). By comparing the results presented in the four chapters, we can determine to what extent certain factors have different impacts on innovation, depending on the type of policy that is under investigation (compare, Gray, 1973). The overall expectation was that the administrative and the mandated innovations are more reliant on resources, and less on motivations, whereas the political and the voluntary innovations are less resource intensive, and are thus more sensitive to motivations. We expected obstacles to be equally important for all four types of innovation. In Chapter 2 we investigated a mandated administrative innovation, and in Chapter 3 we investigated a mandated political innovation. In Chapter 4 we investigated a voluntary administrative innovation, and in Chapter 5 a voluntary political innovation. In this final chapter we first provide the answers to the sub-questions that were central to the four empirical chapters (sections 2.1-2.4). These answers to our sub-questions are followed by an overall summary of results for the four empirical chapters (section 2.5). Then in section 3, we answer our main research question by comparing the effects of motivations, obstacles, and resources for the four different innovations. Followed by a discussion of some of the most important results and suggestions for future research. This discussion is structured around the four points of scientific progress - as mentioned in Chapter I - to which we contributed: the decentralization-thesis, the investigation of different types of innova- 
tions, the Netherlands as empirical domain, and timing and content as measures of innovation. Thereafter, we discuss one additional point that relates to the past performance measures in Chapters 2 and 4 and to the more general matter of innovativeness as being either issue specific or a general trait of governments (see: Boehmke \& Skinner, 20 I 2; Gray, I 973; Walker, I969). By presenting new empirical results based on an alternate view of the dependent variables from the four empirical chapters we reflect on the issue whether municipalities show comparable levels of innovativeness across different policy areas. Finally, in section 4 we shortly summarize the main results of this dissertation.

\section{Answers to the sub-questions \\ 2.1 Answer to sub-question one}

In Chapter 2 of this dissertation we studied the timing of the adoption of a mandated administrative innovation: the Basic Registration Addresses and Buildings (BAG). The BAG is a nationwide database that contains all municipal information about all addresses and buildings in the Netherlands. This e-government innovation, announced in 2008 and to be realized before July I, 2009, was aimed at creating a nationwide coherent database. Public institutions as well as private companies are among its users. In the course of the years, different customers increasingly used information provided by the nationwide BAG facility (LV BAG). For example, from 20 I 3 onwards the fire corps of Amsterdam-Amstelland uses among other data sources - such as, geographic data, the monumental status of buildings, and figures from Statistics Netherlands - also data from the BAG to create digital risk profiles (Binnenlandsbestuur.nl, 20 I 3). Another example, which indicates the large potential of the use of BAG-data, is the use of it for the navigation of ambulances (E-overheid.nl, 20 I 2). Municipalities were mandated to adopt this new nationwide system, and they had to provide all information about all addresses and buildings within their municipal borders to this system. Initially they had to do this before July I, 2009. Later the deadline was postponed until January I, 20 I I. The first sub-question we answered was: ( I) To what extent do differences exist among Dutch municipalities in the timing of the adoption of BAG, and (2) how can we explain these differences?

The first (descriptive) part of sub-question one was answered by looking at all individual adoption dates from all municipalities $\left(\mathrm{N}_{4} 429\right)$ between 2008 and 20 I I. We investigated differences in adoption dates by eyeballing the geographic spread of adoptions (Figures I-4 in Chapter 2), and by observing the cumulative number of adopters per month (Figure 5 in Chapter 2). More in detail, Table A I in Appendix A of Chapter 2, shows that $\mathrm{I} \%$ of the municipalities adopted BAG before the first deadline on July I, 2009. On July I, $2 \circ$ I $\circ$ approximately $15 \%$ of all municipalities had adopted BAG. Five months later, on December I, $20 \mathrm{I} 0,58 \%$ adopted BAG, and before the second deadline on January I, 20 I I $97 \%$ of all municipalities had adopted BAG. The last 3 percent adopted not later than April 8, 20 I I. 
Beforehand we posited the explanatory question to what extent the pattern of adoptions for this particular mandated innovation follows the theoretically well-known s-shaped learning curve (Rogers, 2003) that is often found for voluntary innovations. By investigating the existing differences among municipalities in the timing of the adoption of the BAG, we found that the cumulative number of adoptions (Figure 5 in Chapter 2) only to some extent resembled an s-curve. To assess similarities, it is possible to compare the s-curve as we have discussed in Chapter I, Figure I with the cumulative curve in Chapter 2, Figure 5. The answer to the descriptive part of sub-question one is, that there was considerable variation among municipalities in the timing of the adoption of BAG.

The second (explanatory) part of sub-question one was answered by testing hypotheses concerning the motivations, obstacles, and resources for innovation. We expected that for this highly technical administrative innovation it would be primarily resources that are important for explaining differences in innovativeness among municipalities. As expected, motivations were less important than resources. Amongst the motivational factors only one factor (the ideology of the local government council) did have an impact. When the political composition of a local council was more similar to that of the governing coalition of the national government, these municipalities were more likely to adopt the innovation relatively early. Furthermore, our findings indicate that obstacles were unrelated to differences in the timing of the adoption of BAG. Resources were clearly important: municipalities that were better informed, have performed better on e-government in the past, and municipalities that are included in more extensive policy networks were more innovative. Thus, as we expected for the adoption of an administrative mandated policy, the answer to the second part of subquestion one is, that differences in innovativeness are explained primarily by resources, and only to a limited extent by motivations. In view of the decentralization-thesis our conclusion for sub-question one reads that rather than being motivated by local needs and priorities it were foremost resources that dictated the speed of innovations.

\subsection{Answer to sub-question two}

In Chapter 3 of this dissertation we studied the factors that determined differences in the timing of the realization of a mandated political innovation: the realization of Centers for Youth and Family (CYFs). Municipalities in the Netherlands were obliged to realize a CYF within their municipal boundaries (J\&G, 2008). At least one recognizable physical place in which organizations responsible for youth health care collaboratively offered their services to citizens had to be provided before the end of the year 20 I I. The main goals of the national government that accompanied the realization of CYFs, were to increase the quality of youth care and to increase collaboration between different partners in youth care, and furthermore, to provide parenting advice and support for all families (J\&G, 2007; Van Eijck, 2006). For the realization of CYFs municipalities received financial resources from the 
Broad Goal-oriented Grant Youth and Family. Because municipalities were financially assisted by the national government, and because it was a political innovation, we expected that motivations were more important than resources. Sub-question two was: ( I) To what extend do differences exist among Dutch municipalities in the timing of the realization of a CYF, and (2) how can we explain these differences?

To answer the first part of sub-question two - the descriptive part - we made an overview of CYF adoptions per year for all municipalities. We investigated the differences in timing between municipalities by looking at the cumulative number of adopters over time (Table 2 in Chapter 3). We found that I $3 \%$ of the municipalities realized a CYF by the end of 2008 , and a year later, by the end of $2009,26 \%$ realized a CYF. Approximately $62 \%$ realized a CYF by the end of 2010 , and almost $100 \%$ of the municipalities did this before the end of 20 I I. Only one additional municipality realized a CYF in 20 г 2. We have not yet shown - due to space considerations in the original journal article on which Chapter 3 is based - the cumulative number of CYF adoptions. Here, the cumulative distribution of CYF-adoptions is shown in Figure I. Compared to the innovation in Chapter 2 it is somewhat more difficult to observe a continuous innovation process for CYF-adoptions. This is because in Chapter 2 we had information about the months in which adoptions took place, and here we have the years in which municipalities adopted. For graphical representation this might be somewhat problematic, however, years are the most commonly used time interval to analyze differences in innovativeness (for example, Berry \& Berry, I 990, 20 I 4; Maggetti \& Gilardi, 20 I 4; Sluiter, 20 I 2). Similarly as for the cumulative curve for the BAGadoptions in Chapter 2, we might ask ourselves the exploratory question to what extent the pattern of CYF-adoptions follows the well-known s-curve from the literature (Rogers, 2003). Figure I shows that the cumulative curve of CYF-adoptions indeed resembles to some extent an s-curve. Again, to assess similarities, it is possible to compare the s-curve as we have discussed in Chapter I, Figure I with the cumulative curve in Chapter 2, Figure 5. The answer to the first part of sub-question two is that municipalities were found to differ considerably in their moments of CYF realization.

To answer the second (explanatory) part of sub-question two we explained the differences in timing of CYF-adoptions among municipalities with characteristics of municipalities. We tested hypotheses concerning the effects of motivations, obstacles, and resources for innovation. We found that the degree of political alignment between the council of the municipality and the national governments' coalition was a motivation for earlier CYF realization. This means that when a local government council is politically more similar to the national governments' coalition a municipality is more likely to adopt the innovation relatively early. Regarding the obstacles for innovations, we found that these were unrelated to differences in the timing of the realization of CYFs. Furthermore, we also found that organizational capacity, and policy networks were resources for the earlier realization of CYFs. Opposite to what we expected for this mandated political innovation - and 
despite the financial compensation municipalities received from the Broad Goal-oriented Grant Youth and Family - the answer to the explanatory part of sub-question two is, that it were mainly municipalities' command over resources that was important for innovation, rather than their motivations for innovation. With respect to the decentralization-thesis, for sub-question three we conclude that, rather than motivational factors such as local needs and local priorities, resources were most important for determining the speed with which this innovation has spread among municipalities.

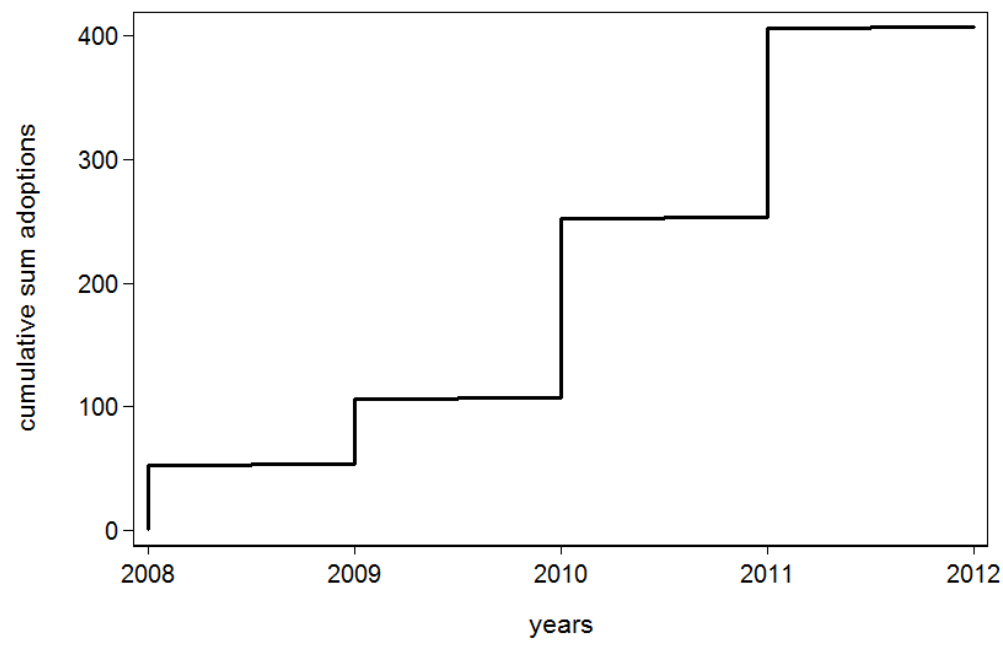

Figure 1. The cumulative distribution of CYF-adoptions for 407 municipalities in the Netherlands between 2008 and 2011.

\subsection{Answer to sub-question three}

In Chapter 4 we studied the content of a voluntary administrative innovation. We investigated differences in the extent of e-democracy innovation on municipalities' websites for all municipalities in the Netherlands $(\mathrm{N}=407)$ between 2007 and 20 I I. Municipalities in the Netherlands are responsible for the quality of local democracy, and one possibility to increase municipalities' own democratic infrastructure is to provide citizens with online opportunities to participate and to inform themselves. Municipalities are not formally held responsible by the national government (or province) for the execution of local egovernment applications. It is up to the municipalities themselves to decide the extent of edemocratic facilities they provide. Sub-question three, about differences in the extent of edemocracy development, was: ( I) To what extent do differences exist in the extent of edemocracy development on Dutch municipalities' websites, and (2) how can we explain these differences? 
To answer the first (descriptive) part of sub-question three, we described the operationalization of our e-democracy scale in Table $\mathrm{I}$ in Chapter 4 . Due to space considerations in the original journal article on which Chapter 4 is based, we did not present the distribution of edemocracy scores in Chapter 4, but instead we present it here in Figure 2. The e-democracy scale that we created had a theoretical minimum of zero, and a theoretically possible maximum score of 300 . The actual values of scores on the scale in our sample were for all municipalities somewhere between I I and 283 , with a mean score of 97 , and a standard deviation of 36 . Figure I resembles a normal distribution with some small deviations upwards. Based on the distribution of e-democracy scores in Figure 2, and based on the information in Table $\mathrm{I}$ in Chapter 4 , the answer to the first part of sub-question three is that differences in the extent of e-democracy development between municipalities were found to be considerable.

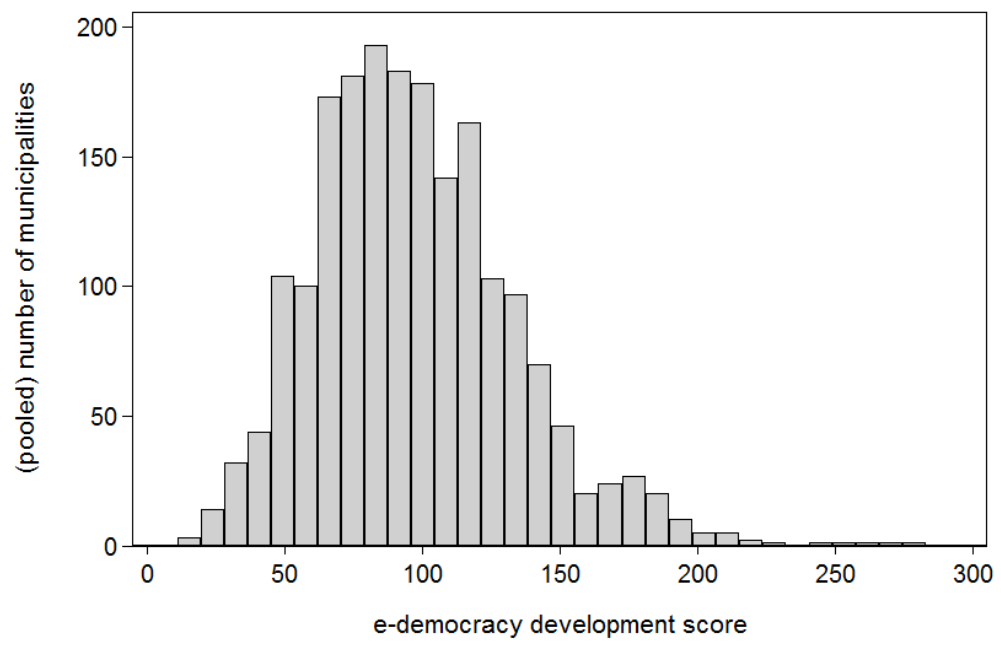

Figure 2. The distribution of e-democracy scores for municipalities in the Netherlands between 2007 and $2011(\mathrm{~N}=1945, \mathrm{~N}$ Clusters=407).

To answer the second (explanatory) part of sub-question three, we tested hypotheses about the motivations, obstacles, and resources for innovation. We expected that for a voluntary and administrative innovation, that it would be a combination of motivations and resources that could explain differences in innovativeness between municipalities. We found that municipalities developed more extensive e-democracy applications when they were motivated by a low voter turnout, more potential e-government users, a political ideology in favor of e-government practices, and politicians with personal preferences in favor of e-democracy. Regarding the obstacles for innovation, we found that more fragmented mu- 
nicipal councils were more innovative e-democracy developers. The resources that mattered for the development of e-democracy measures were a larger organizational capacity, better egovernment performance in the past, and when a Mayor or Aldermen in the municipal executive board was explicitly charged with specific ICT responsibilities. The answer to the explanatory part of sub-question three is that motivations and resources explained differences in innovativeness almost equally. Also, obstacles were responsible for differences among municipalities, but opposite to what we predicted, they had a positive effect on innovation in this voluntary administrative policy. Regarding the decentralization-thesis, for subquestion three, we conclude that not exclusively resources (and obstacles) were important for innovations, but there was also a role for motivational factors such as local demands, needs, and ideological priorities.

\subsection{Answer to sub-question four}

In Chapter 5 we studied the factors that could explain differences in the amount of innovation in policy content for a political voluntary innovation. We investigated differences in innovativeness in content of this policy after the lifting of the brothel ban in the year 2000 for a sample of all Dutch municipalities ( $\mathrm{N}=328$ out of $\mathrm{N}=537)$. In October 2000, prostitution in the Netherlands was legalized by means of enacting a new law that lifted the ban on brothels. This reform was intended to bring an end to irregularities in the sex industry. An important, and strict distinction was made between voluntary prostitution, and forced prostitution. The first form of prostitution became legal and had to be regulated as sex work, and for the latter form of prostitution offenders had to be prosecuted as criminals (Outshoorn, 2004). Municipalities became responsible for regulating prostitution, but they were not mandated to include prostitution laws in local regulations. To help in shaping local prostitution regulations, the Dutch Association of Municipalities (VNG) provided municipalities with a 'model legislation.' We investigated to what extent municipalities copied the model legislation, and to what extent they adapted the model legislation to local priorities and local needs. We did so by addressing sub-question four: ( I) To what extent do differences exist between Dutch municipalities in the amount of adaptations in the content of a prostitution model-regulation, and (2) how can we explain these differences?

The first (descriptive) part of sub-question four was answered by comparing the model legislation with all the local legislations of the municipalities. We found that overall the legislation developed by municipalities showed much resemblance with the model legislation provided by the VNG, but at the same time we showed that there was considerable variation between municipalities in the amount of overlap with the model legislation (Figure I in Chapter 5). When we looked more closely to the numbers of substantive changes municipalities made (Figures 2-3 in Chapter 5), we found that the number of substantial changes to the model legislation varied between zero (no substantive changes are made) and 
20. The answer to the first part of sub-question four is, that differences among municipalities in the amount of adaptations were considerable.

To answer the second part of sub-question four we tested hypotheses concerning municipalities' motivations, obstacles, and resources for innovation. For this voluntary and political policy we expected that especially motivations were important for explaining differences in the extent of customization of the content of the model legislation. However, we found that motivations failed to assure that municipalities adapted more to the model legislation. Obstacles were indeed found to hamper innovation, as politically more fragmented municipalities copied the model legislation to a larger extent. Furthermore, rather than motivations, it were size-related municipal resources that made municipalities alter the model legislation. The answer of the second part of sub-question four is that, the extent of innovation in a voluntary political policy was not the result of motivations, but foremost a result of obstacles and resources. In view of the decentralization-thesis our conclusion for subquestion four reads that rather than being motivated by local needs, demands and political priorities it were foremost resources (and obstacles) that determined the extent of innovation.

\subsection{Summary of findings}

Table I gives a systematic overview of the answers to the explanatory parts of the subquestions. It shows the factors contributing to explaining differences in innovativeness among municipalities. For all factors the results of the hypotheses tests from the four empirical chapters are shown. In each column the plus-symbol (+) indicates a positive and significant effect, and the minus-symbol (-) indicates a negative and significant effect. Zero (o) means that no effect was found, and a dot (.) indicates that for this factor no hypothesis was tested. For factors that we tested multiple hypotheses the results are separated by an ampersand (\&).

\section{General conclusion and discussion}

Throughout this dissertation we provided four contributions to the literature. First, we tested the decentralization-thesis against an alternative explanation thereby adding knowledge to the theoretical and practical decentralization debate. Second, we investigated different types of policies by examining whether explanations that affect innovativeness are robust when we compare different types of policy innovations. Third, we broadened the empirical domain by investigating differences in innovativeness among municipalities in the Netherlands. Thereby we were the first to consider for all Dutch municipalities factors external to municipalities, besides the more widely studied internal factors for innovation. Fourth, we investigated both differences in innovativeness based on timing of the adoption of innova- 
tions as well as differences in innovativeness based on the content of innovations. Consequently, we reflect on the most important issues related to these four issues, and lastly, we also present some new empirical results - as announced in the introduction of this chapter to contribute to the historical question whether innovativeness should be considered as a general trait of governments or as a domain specific attribute of governments.

We start by providing an answer to our main research question and we draw conclusions about the importance of motivations and resources for explaining innovation. The answer on the main research question is followed by a reflection on what this answer means for the general validity of the decentralization-thesis (sub-section 3. I). In the following sub-sections we first reflect on issues related to the investigation of different types of policies (sub-section 3.2). This is followed by a reflection on the investigation of external (network) factors in the Netherlands (sub-section 3.3). Then we shortly reflect on timing and content (sub-section 3.4). At last we present new empirical material and reflect on innovativeness as issue specific or as a general trait of governments (sub-section 3.5).

Table 1. Factors explaining innovation.

\begin{tabular}{|c|c|c|c|c|}
\hline & $\begin{array}{c}\text { E-government } \\
\text { (Chapter 2) }\end{array}$ & $\begin{array}{c}\text { Youth and Family } \\
\text { (Chapter 3) }\end{array}$ & $\begin{array}{c}\text { E-democracy } \\
(\text { Chapter 4) }\end{array}$ & $\begin{array}{l}\text { Prostitution } \\
\text { (Chapter5) }\end{array}$ \\
\hline \multicolumn{5}{|l|}{ Motivation } \\
\hline \multicolumn{5}{|l|}{ Policy-seeking } \\
\hline Problem severity/Needs & $\circ$ & $\circ$ & + & $\circ \& \circ$ \\
\hline Political/Citizen demands & . & . & $\circ \&+$ & - \\
\hline Ideology & + & $\circ \&+$ & $+\&+$ & - \\
\hline \multicolumn{5}{|l|}{ Vote-seeking } \\
\hline Electoral competition & . & $\circ$ & $\circ$ & . \\
\hline \multicolumn{5}{|l|}{ Obstacles } \\
\hline Party fragmentation & $\circ$ & $\circ$ & + & - \\
\hline Complexity & $\circ$ & . & . & . \\
\hline \multicolumn{5}{|l|}{ Resources } \\
\hline \multicolumn{5}{|l|}{ Human/financial } \\
\hline Organizational capacity & $\circ$ & + & + & + \\
\hline Past performance & + & . & + & . \\
\hline Information & + & . & . & . \\
\hline Political portfolio & . & $\circ$ & + & . \\
\hline \multicolumn{5}{|l|}{ Social } \\
\hline Professional network & . & $\circ$ & $\circ$ & $\circ$ \\
\hline Regional policy network & + & + & . & . \\
\hline
\end{tabular}

\subsection{Answer to the main research question}

We have now arrived at answering our main research question, which reads as follows: (I) To what extent do differences exist among Dutch municipalities in their execution of decentralized policy responsibilities, and (2) which factors can explain these differences? To answer 
this question we have investigated four different innovations: one innovation for every combination between mandatory or voluntary innovations, and administrative or political innovations. The answer to the descriptive part of our main-question is based on the four answers on the descriptive parts of our four sub-questions. Our answer reads that, for all four cases differences between municipalities in the extent of innovativeness were considerable, both in terms of timing for the mandated innovations, as well as in terms of content for the voluntary innovations.

For the answer to the explanatory part of our main research question in the introduction of Chapter I we hypothesized that the influence of motivations and resources on the extent of innovation might be different, depending on the type of policy that is being examined. We expected the effects for the obstacles to be comparable across the four different policies. This is the reason why in Table 4 only the expectations and findings for the motivations and resources are shown. In Table 4 the expectations of the influence of motivations and resources for explaining differences in innovativeness among municipalities are shown in the columns 'predicted'. These columns correspond with the expectations we outlined in Table 3 in Chapter I. Our findings regarding the influence of motivations and resources are based on the answers on the four explanatory parts of our sub-questions. For each of the four innovations the findings are shown in the columns 'outcome'. In Table 2 it is shown that our expectations for the administrative policies are confirmed, and that our expectations for the political policies are for the most part rejected. For administrative policies our conclusion is that it were resources, and to a lesser extent motivations that were important. For the political innovations we can conclude that resources municipalities had were most important. Mandated innovations, to conclude, whether they are administrative or political innovations, were also foremost determined by resources. We can conclude for the voluntary innovations that they were for the most part determined by resources, and only to a limited extent determined by motivations. The impact of obstacles was mixed. Obstacles only influenced the voluntary innovations: they had a positive impact on the administrative innovation, and a negative impact on the political innovation.

Table 2. The importance of motivations and resources by innovation type: predictions and outcomes.

\begin{tabular}{|c|c|c|c|c|}
\hline & \multicolumn{2}{|c|}{ Administrative } & \multicolumn{2}{|c|}{ Political } \\
\hline & Predicted & Outcome & Predicted & Outcome \\
\hline Mandated & Resources & Resources & $\begin{array}{c}\text { Motivations + } \\
\text { Resources }\end{array}$ & Resources \\
\hline Voluntary & $\begin{array}{c}\text { Motivations + } \\
\text { Resources }\end{array}$ & $\begin{array}{c}\text { Motivations + } \\
\text { Resources }\end{array}$ & Motivations & Resources \\
\hline
\end{tabular}

Thus, the answer to the explanatory part of our main research question is, that the influence of obstacles is negligible, that motivations were only marginally responsible for 
differences in innovativeness, and that resources could foremost account for differences in innovativeness among municipalities. Again, this result shows that decentralized innovations were mainly guided by resources such as organizational capacity, past performance, and regional policy networks, and not so much by local motivations to shape local policies to local needs and demands, and to differences in political priorities. These findings definitely challenge the idea of proponents of decentralization - and the decentralization-thesis - that municipalities are capable of developing innovative policies based on specific local priorities and local conditions (compare, Beetham, i 996; Pollitt, 2005). Thus, showing innovative behavior is certainly possible for municipalities having sufficient amounts of resources, and to a lesser extent for municipalities without sufficient resources.

\subsection{Different types of policies}

The first point we would like to make is that by examining innovations in different policy areas it was possible to examine whether explanations vary between policy types. In contradiction with the old-established argument, that factors explaining differences in innovativeness are dependent on the type of policy under investigation (Gray, i 973), we have found that this is only true to a limited extent. For both the administrative and the political innovations - either mandatory or voluntary - in this dissertation we found innovations in all these different policy areas to be most reliant upon resources. Municipalities have all shown to possess a considerable potential to innovate - at least, in the four policy fields under study in this dissertation - municipalities have made considerable efforts to realize new policies. However, when local motivations such as political and citizen demands, and social needs hardly play a role in developing innovations, the question remains whether municipalities are really capable of improving the efficiency and effectiveness of local policies, and in the long run - via these policies, as proponents of the decentralization-thesis believe - be able to enhance the quality of local democracy.

Second, we have investigated both voluntary and mandated innovations, because we were interested in similarities and differences between explanations for differences in innovativeness among these different types of policies. We have tested similar explanations for these types of policies, but we have also tested new explanations that we considered to be only theoretically relevant in mandated policy settings. The hypothesis we only tested for the mandated innovations is the political alignment hypothesis: municipalities will innovate earlier when their party preferences are more aligned to those of the national government. In Chapter 2 ad Chapter 3 we investigated the effect of political alignment between the national government and local governments for the speed by which innovations were adopted. It has been often argued and empirically established that the ideological composition of the governments influences its inclination for innovation (Berry \& Berry, I 990, 2007; Boehmke \& Witmer, 2004; Sugiyama, 2008; Tolbert, Mossberger, \& McNeal, 2008). We also knew 
from the literature that top-down influences can be important for how innovations get adopted (Berry \& Berry, 2007; Karch, 2006). We have combined ideology and top-down pressures in one testable hypothesis, and we expected these two factors to express themselves via ideological differences between the national government and the municipalities. In both mandated cases we tested the hypothesis that more ideological similarity led to innovations being adopted earlier. For both the administrative innovation as well as the political mandated innovation we found support for our newly derived hypothesis. There are two plausible reasons for the effect of political alignment on the timing of adoptions. The first one is that municipalities might, due to ideological similarities with the national government, feel greater (ideological) affinity with the innovation that has to be implemented. This might be the reason for the political innovation in Chapter 3. Second, it might also mean that a municipal council obeys sooner when political parties of the same political signature mandate an innovation. This reason was most likely the cause for the effect of political alignment in the case of the administrative innovation in Chapter I. Deriving the political alignment hypotheses became relevant, because we addressed new questions about municipal innovations in mandated settings. In settings of voluntary innovation the political alignment hypothesis is theoretically not relevant and therefore has not been tested before in other studies. For this reason we cannot compare our result with results from earlier innovation studies. The robustness of the political alignment effect will have to be proven by replication in comparable cases of mandated innovation. To assess the general validity of the political alignment hypothesis, replication should preferably be considered in other decentralized governmental contexts than the Netherlands.

Lastly, according to our findings, for the political innovations it did not matter whether municipalities had a local Mayor or Aldermen acquainted with a policy specific political portfolio or not. For the administrative innovation in Chapter 2 we did not have the opportunity to test this hypothesis, because there was no data available. For the administrative edemocracy innovation in Chapter 4 we found a positive effect of having a policy specific political portfolio. These findings might indicate that e-democracy developments are politically more salient than we might have expected beforehand based on its administrative nature, and that political innovations might not be so politically salient after all. It surprised us that we have found no effect of political portfolios for the political innovations, because we expected policy prioritization by means of political attention to be an important resource for the implementation of new policies (compare, Jacoby \& Schneider, 200 I). Many researchers have mentioned the possible importance of policy entrepreneurs and policy advocates for their influence on the policy innovation process (Berry \& Berry, 2007, 20 I 4; Mintrom \& Norman, 2009). However, the empirical investigation on the effects of policy advocates and policy entrepreneurs on innovation is not so widespread. Future research might benefit from a focus on these explanations for innovation. It can be the case that certain influences - such as for example a Mayor or Aldermen with an issue specific portfolio, 
as we hypothesized - are more important in earlier or later phases in the adoption and implementation process (compare, Karch, 2007a; Konijnendijk, Boere-Boonekamp, HaasnootSmallegange, \& Need, 20 I 4).

\subsection{Network factors in the Netherlands}

The first point that we make here is that we have expanded the domain of investigating innovations from research that mainly took place among U.S. States to municipalities in the Netherlands. Most important was that for the Netherlands we were the first to explain differences in innovativeness among all Dutch municipalities by also taking into account external influences. Besides examining internal factors, in this dissertation we have also aimed to explain differences in innovativeness by taking into account explanations external to municipalities (compare, Berry \& Berry, 2007, 20 I 4; Boehmke \& Witmer, 2004; Walker, 2006). We were the first to have found an effect for the influence of regional policy networks on individual adoption decisions, in the context of Dutch municipalities. Historically, in the innovation literature much emphasis has been placed on adoption decisions by one government being influenced by prior adoption decisions from other governments (Berry \& Berry, I 990; Walker, I 969). In the early literature it was assumed that nearby governments and especially neighboring governments and governments in the same region would influence each other's policy innovation decisions (Berry \& Berry, 2007). Later research has shifted this attention from neighboring and regional influences to influences of policy networks, because network meetings would allow politicians and policymakers to successfully exchange information and ideas (Füglister, 20 I г a, 20 I г b; Sugiyama, 2008). However, attention also shifted to measures of policy networks because it was not always clear why exactly proximity to neighbors or to other governments in the same region would lead to this influence (Beck, Gleditsch, \& Beardsley, 2006; Karch, 2007b). For the mandated innovations in Chapter 2 and Chapter 3 we have taken into account real existing and functional regional policy networks and found proof for governments in these networks being sensitive to other governments adoption decisions. In these instances governments in the same policy network function as a resource from which other governments can learn (Berry \& Berry, I 990). The implication of our findings is that policy networks are important in mandated settings, just as they are important in voluntary setting of policy innovation (Füglister, 20 I га, 20 I I b; Sugiyama, 2008). A focus on policy networks as places where intergovernmental learning is possible can be a promising avenue for future research on mandated innovations.

The second and last point we make here is that for voluntary innovations we considered external influences only via professional networks. We did not consider the influence of external effects in regional networks. In these two cases we did not test hypotheses for the effect of regional network because theoretically there were no distinguishable relevant func- 
tional regional networks. In Chapter 2, for the mandated administrative innovations, we explained that the Ministry of VROM divided municipalities into regional contact groups. In Chapter 3, for the mandated political innovation, we showed that municipalities were all member of a regional Municipal Health Services network. In both instances we considered these networks to be places where municipalities could exchange experiences and ideas about the process of implementation of the particular innovation. For both the voluntary administrative and the voluntary political innovation there were no functional regional networks that could be considered. Especially when it concerns e-government innovations, the influence of other governments in a fixed region - even more so when these regions are not formally existing and actually functional - is highly questionable. Governments can compare their own online efforts with the websites from all other governments in the country. They are not limited to regional comparisons. In addition, when using fictional regions, contact among governments is assumed, while there does not need to be any contact. Research on who influences whom is difficult when no formal networks exist for the particular policy under consideration. This was the case for both innovations in Chapter 4 and Chapter 5. Even though, when we would somehow have been able to operationalize these networks, it would still have been a difficult task to determine how governments influence each other when it concerns the content of the innovation. Future research should try to work out - both theoretically and methodologically - methods for measuring network influences in research focusing on the content of innovations using interval measures.

\subsection{Timing and content of the innovations}

There is one important point we make here. In Chapter 4 we applied a novel way of investigating the content of a political innovation. We used plagiarism software Ephorus to examine the overlap between a policy template provided by the Association of Dutch $\mathrm{Mu}$ nicipalities (VNG) and municipal by-laws of the same policy. We have shown that the information provided by Ephorus in combination with an extensive qualitative content analysis in Atlas.ti provides very important and useful information about the extent and reasons why municipalities modify the content of a policy template. The method we used provides a significant opportunity for future research that would like to investigate similar vertical cases (one national template is used by all local jurisdictions) or that would like to make horizontal comparisons (one or more local policies might be compared with documents in all other jurisdictions). It is important to investigate administrative as well as political innovations, because the visibility and salience of the policy are important when it comes to the extent to which national organizations generate information about policy innovations (Karch, 2007a). Also, McCann, Shipan and Volden (20 I 5, p. 2 I) found that "national discussions may influence state policymakers' perceptions of the benefits of the policy, of the importance of the issue, and of their own need to act". The responsiveness of local politi- 
cians and local policymakers to a top-down provided policy template might be dependent on the type of policy that is being examined. Specifically for the Netherlands we might expect that municipal responses are different depending on whether the policy template is provided for an administrative or political innovation, and also on how much national discussion there is about the policy that action is required for.

\subsection{Innovativeness as trait or as domain specific}

In the literature it has been recognized that previous experiences with policies might be important for the ease with which similar innovations are adopted and implemented at a later moment in time (Berry \& Berry, 2007, 20 I 4). This relates to the original conception of innovation by Walker ( I969), who regarded innovativeness as a general trait of governments, instead of innovativeness as a policy specific characteristic (see also, Boehmke \& Skinner, 20I2). Considering innovativeness as a general trait of governments means that when a government is innovative in one policy area it will probably also innovative in other policy areas. Consequently, some studies answer the question why some governments are in general more innovative than other governments (for example, Eyestone, I 977; Gray, I973; Walker, I 969; Welch \& Thompson, I980). However, some governments might - due to their prior experiences with similar policies - be more innovative in some policy areas and not in others (Gray, I973). Despite the recognition that existing policies in a jurisdiction, and the previously acquired experience and expertise with these policies might have implications for new policy decisions, it has received hardly any empirical testing (Berry \& Berry, 2007, 20I4). Some research in e-government has found that past performance is an important resource for later developments in the same policy field (Ahn, 20 I I; Moon, 2002). In Chapter 2 and Chapter 4 we found past performance to be a predictor for innovation. We have hereby contributed to the knowledge about the influence of previous experiences on later innovations in administrative policies, but we did not - due to a lack of data - test this explanation for the political innovations in Chapters 3 and 5. Of course, it would be unwarranted to make broad theoretical claims on the basis of our findings. Nevertheless, it certainly substantiates the need for research focusing on past performance explanations. For political innovations the methodological challenge to come up with good measurements might be a more difficult task then for the administrative innovations.

We explained in the introduction of this chapter that we would show additional empirical results about municipalities' general levels of innovativeness. By comparing innovation scores across different types of innovations we contribute casually to the answer on the old established question - as just shortly discussed in the paragraph above - whether innovation should be considered a general trait of governments, or whether it should be considered a policy-dependent characteristic of governments (Gray, I973; Walker, I969). In other 
words, do governments that show innovative behavior in one type of policy, show the same innovative behavior in other types of policies? We present differences in innovativeness between municipalities in a different manner than we have done before, and make a comparison of municipalities' levels of innovativeness across the four innovations.

To compare innovativeness scores across all four policies, based on the dependent variables in each chapter we created three categories of municipalities. Our categorization is loosely based on Rogers' (2003) innovation adoption curve. We condensed the innovators $(2.5 \%)$ and early adopters ( $13.5 \%)$ into the first category of innovators. The early majority $(34 \%)$ and late majority $(34 \%)$ are taken together in the second category. In the third category are the laggards (г6\%). This results in the following categorization: most innovative municipalities $\left( \pm_{\mathrm{I}-\mathrm{I}} 6 \%\right.$ of all municipalities), moderately innovative municipalities $\left( \pm_{\mathrm{I}} 7^{-}\right.$ $84 \%)$, and least innovative municipalities ( \pm 8 5-1 $00 \%)$. We made a categorization based on percentages, because it was not possible to create an objective measure of innovativeness for the four different research cases. To allow for a comparison of innovativeness across policy types, the categorization we constructed is a relative measure of innovativeness based on municipalities' innovation scores compared to the scores of other municipalities. For the innovations focusing on timing we considered the $\pm_{\mathrm{I}} 6 \%$ earliest adopters as most innovative,

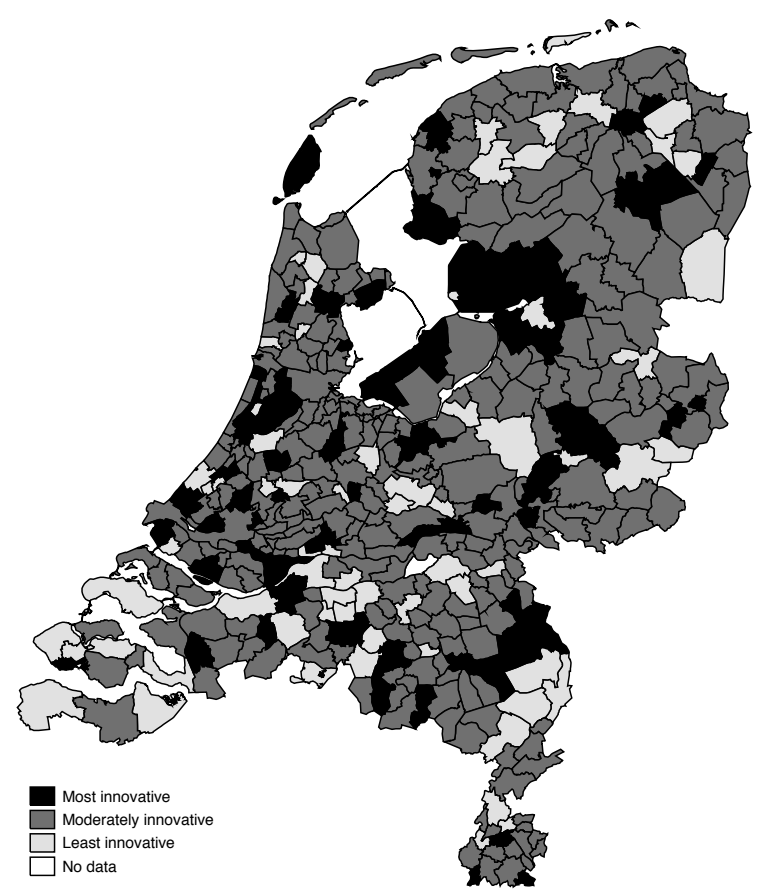

Figure 3. Innovativeness score for the mandated administrative innovation. 


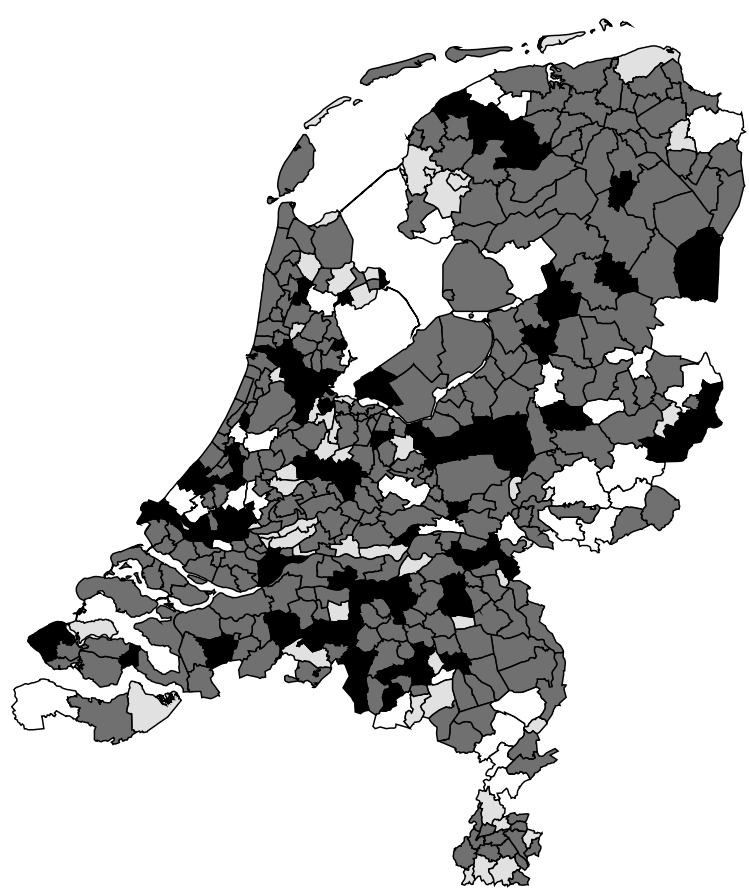

Figure 4. Innovativeness score for the voluntary administrative innovation.

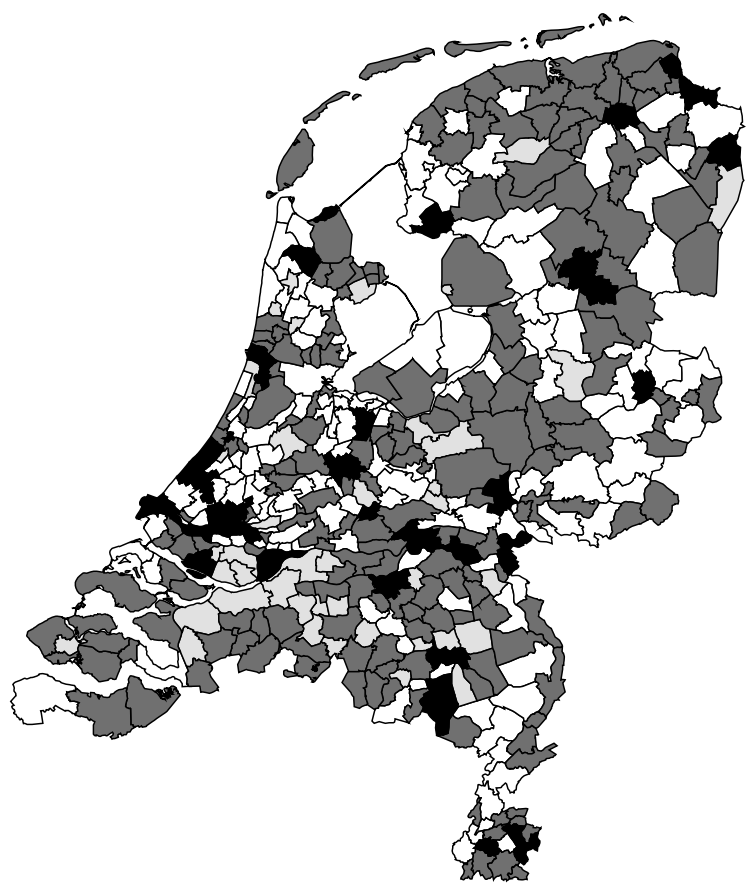

Figure 5. Innovativeness score for the voluntary political innovation.

Source Figures 3-5: () 20 I I, Statistics Netherlands/ Land Registry Office, Zwolle, 20 I I; own calculations. 
the $\pm 68 \%$ following adopters as moderately innovative, and the last adopting $\pm_{\mathrm{I}} 6 \%$ as least innovative. The innovations focusing on the content were categorized by considering the $\pm_{\mathrm{I}} 6 \%$ highest scoring municipalities as most innovative, the following $\pm 68 \%$ as moderately innovative, and the lowest scoring $\pm_{\mathrm{I}} 6 \%$ of the municipalities as least innovative.

For a graphical representation of the innovation scores, we created one map for each policy. We do not present a figure for the political mandated innovation due to restrictions on the use of data from Chapter 3. Figures 3 to 5 show maps of the Netherlands with municipalities' innovation scores for three innovations. In black are the most innovative municipalities, in dark-grey the moderately innovative scores, and in light grey the least innovative municipalities. The municipalities that are colored white have no innovation score for the particular policy. By eyeballing these figures it is possible to see whether a municipality that was innovative in one policy was also innovative in another policy. Or more general, whether one municipality belongs to one of the innovation categories for one policy, and also belongs to the same innovation category for the other policies.

In addition to Figures 3-5, Table 3 shows the number and percentages of municipalities in each category of the innovation scores for all four innovations. If we look at the innovation scores for all innovations together it shows that only $0.4 \%$ of all municipalities was 'most innovative' in all four policies. Furthermore, I $9.2 \%$ of the municipalities were moderately innovative in all four policies, and only $0.7 \%$ was in the 'least innovative' category for all four policies. More than $53 \%$ of the municipalities never had a 'most innovative' score, and more than $42 \%$ never had a 'least innovative' score. Only just over $3 \%$ of the municipalities were never in the 'moderately innovative' category. The 'moderately innovative' category seems most stable with over $56 \%$ of the municipalities making this score for either three innovations $(37.3 \%)$ or for four innovations ( $19.2 \%$ ). Figures 3-5 and Table 3 have shown that there does not seem to be a clear pattern of innovativeness scores across all four policies, at least not at the high and low ends of the innovation scores. This favors the argument that innovativeness is more a policy dependent characteristic than that it is a general characteristic of governments.

Table 3. Number of times municipalities had similar innovation scores across all four policy types.

\begin{tabular}{|c|c|c|c|c|c|c|}
\hline & \multicolumn{2}{|c|}{ Most innovative } & \multicolumn{2}{|c|}{ Moderately innovative } & \multicolumn{2}{|c|}{ Least innovative } \\
\hline & $\mathrm{N}$ & $\%$ & $\mathrm{~N}$ & $\%$ & $\mathrm{~N}$ & $\%$ \\
\hline Four times & I & 0.4 & 53 & 19.2 & 2 & 0.7 \\
\hline Three times & 9 & $3 \cdot 3$ & $1 \circ 3$ & $37 \cdot 3$ & 7 & 2.5 \\
\hline Two times & 27 & 9.8 & 8 I & $29 \cdot 3$ & 36 & I 3.0 \\
\hline One time & 92 & $33 \cdot 3$ & 30 & 10.9 & I I 3 & 40.9 \\
\hline Zero times & $\mathrm{I} 47$ & $53 \cdot 3$ & 9 & $3 \cdot 3$ & I I 8 & 42.8 \\
\hline Total & 276 & 100 & 276 & 100 & 276 & 100 \\
\hline
\end{tabular}


We get a more nuanced picture of municipalities' general levels of innovativeness when we consider innovation scores for policies that are similar. Table 2 shows the number and percentages of municipalities that had a similar innovation score for administrative (Egovernment and E-democracy), political (Youth and Family, and Prostitution), mandated (Youth and Family, and E-government), and voluntary (Prostitution and E-democracy) innovations.

Table 4. Municipalities with similar innovation scores across different policy types.

\begin{tabular}{|c|c|c|c|c|c|c|c|c|}
\hline & \multicolumn{2}{|c|}{$\begin{array}{c}\text { Administrative } \\
\text { innovations }\end{array}$} & \multicolumn{2}{|c|}{$\begin{array}{c}\text { Political } \\
\text { innovations }\end{array}$} & \multicolumn{2}{|c|}{$\begin{array}{c}\text { Mandated } \\
\text { innovations }\end{array}$} & \multicolumn{2}{|c|}{$\begin{array}{c}\text { Voluntary } \\
\text { innovations }\end{array}$} \\
\hline & $\mathrm{N}$ & $\%$ & $\mathrm{~N}$ & $\%$ & $\mathrm{~N}$ & $\%$ & $\mathrm{~N}$ & $\%$ \\
\hline Most innovative & I6 & $3 \cdot 3$ & 9 & 3.2 & I० & 3.5 & I I & 2.7 \\
\hline Moderately innovative & I 99 & $4 \mathrm{I} .2$ & I $\circ 6$ & $3^{8.1}$ & I 38 & 47.8 & I 36 & $33 \cdot 7$ \\
\hline Least innovative & 9 & I.9 & 22 & $7 \cdot 9$ & 5 & I.7 & 24 & $5 \cdot 9$ \\
\hline Not is same category & 259 & 53.6 & I 4 I & 50.7 & 136 & 47.1 & 233 & $57 \cdot 7$ \\
\hline Total & 483 & 100 & 278 & 100 & 289 & 100 & $4 \circ 4$ & 100 \\
\hline
\end{tabular}

Neither for the administrative and political innovations, nor for the mandated and voluntary innovations there are clear patterns of municipalities that are always most innovative. Also at the lower end of the innovation scores, there is no clear group of non-innovative municipalities. For all four innovations types, by far, most municipalities are either in the 'moderately innovative' category or they were not in the same innovation category. However, considering the innovativeness scores separately for the four different types of innovations (Table 4 ) gives somewhat larger groups of 'most innovative' and 'least innovative' municipalities than by taking the innovativeness score together for all four policies (Table 3). These findings indicate that municipalities are more often innovative in similar types of policies than they are in different types of policies. Thus, differences in innovativeness among municipalities seem somewhat less arbitrary if we distinguish between political, administrative, mandated and voluntary policies instead of considering overall innovativeness. We can cautiously say that innovation is probably more related to innovative behavior in a specific policy area (compare, Gray, I 973), than that innovation can be considered an overall characteristic of municipalities (compare, Walker, I 969).

\section{To conclude}

This dissertation described four studies on local governments' innovation behavior in the Netherlands. We have shown that the speed by which innovations were adopted, and the extent of innovation in content both seem to be mostly dictated by resources (Chapters I-2 and 4), and only incidentally also by motivations such as local needs, demands, and ideology 
(Chapter 3). Furthermore, obstacles were only of limited importance (Chapter 4-5). Besides the influence of local motivations, obstacles, and resources, factors external to municipalities were also influential. Horizontally, other governments in the same regional policy network were important for municipalities' individual innovation behavior (Chapter 2-3); professional networks however had no effect on innovation (Chapters 3-5). Vertically, a national organization, the Dutch Association of Municipalities (VNG), influenced innovation (Chapter 5). At last, municipalities' policy innovations were also influenced by the national government (Chapter 2-3).

We conclude that differences in the extent of policy innovativeness among Dutch municipalities were foremost the result of differences in their command over resources. Regardless of whether it was an administrative or political innovation, or a mandatory or voluntary innovation, motivations were only marginally important for innovation. Our study clearly shows that municipalities that have the right amount of resources are perfectly well capable to execute the decentralized tasks for which they are responsible - which is at the heart of decentralization. However, the 2015 decentralizations of policy responsibilities in the social policy domain that we mentioned in Chapter I were accompanied by the command to reduce costs. To recall a part of the citation from the coalition agreement of cabinet Rutte II (2012-20 I6) from Chapter I: "Municipalities can better coordinate the implementation of tasks, and thus do more with less money." (Regeerakkoord VVD PvdA, 20 г2, p. 40 ). On the basis of our findings in this dissertation we might argue that decentralization and a simultaneous reduction of expenditures is not a promising combination. 


\section{REFERENCES}

Ahn, M. J. (20 I I). Adoption of Applications in U.S. Municipalities: The Role of Political Environment, Bureaucratic Structure, and the Nature of Applications. The American Review of Public Administration, 4I (4), 428-452. doi: I 0. I I $77 / 02750740$ I 0377654

Beck, N., Gleditsch, K. S., \& Beardsley, K. (2006). Space is more than geography: Using spatial econometrics in the study of political economy. International Studies Quarterly, 50(I), 27-44.

Beetham, D. ( 1 996). Theorising democracy and local government. In D. King \& G. Stoker (Eds.), Rethinking local democracy (pp. 28-49). London: Macmillan.

Berry, F. S., \& Berry, W. D. ( 1990$)$. State lottery adoptions as policy innovations: An event history analysis. American Political Science Review, 84(2), 395-4 I 5.

Berry, F. S., \& Berry, W. D. (2007). Innovation and diffusion models in policy research. In P. A. Sabatier (Ed.), Theories of the Policy Process (second., pp. 223-260). Boulder, CO: Westview Press.

Berry, F. S., \& Berry, W. D. (20 I 4). Innovation and diffusion models in policy research. In P. A. Sabatier \& C. M. Weible (Eds.), Theories of the Policy Process (Third., pp. 307-359). Boulder, CO: Westview Press.

Binnenlandsbestuur.nl. (20 I 3). Digital risk profiles helps firefighters in prevention [In Dutch: Digitaal risicoprofiel helpt brandweer bij preventie]. Retrieved March 25, 2015 , from http://www.binnenlandsbestuur.nl/digitaal/nieuws/digitaal-risicoprofiel-helpt-brandweer-bij.9I 33548.lynkx

Boehmke, F. J., \& Skinner, P. (20 I 2). State policy innovativeness revisited. State Politics E Policy Quarterly, I2(3), 303329.

Boehmke, F. J., \& Witmer, R. (2004). Disentangling diffusion: The effects of social learning and economic competition on State policy innovation and expansion. Political Research Quarterly, 57 (I), 39-5 I. doi: I 0. I I 77/ I 0659 I 290405700 I04

Clark, J. (1 985 ). Policy diffusion and program scope: Research directions. Publius, I 5 (4), 6 I-70.

E-overheid.nl. (2012). Ambulances navigate on BAG [In Dutch: Ambulances navigeren op de BAG]. Retrieved February 2 I , 20 I 2, from http://www.e-overheid.nl/actueel/nieuwsberichten/intItem/ambulances-navigeren-opde-bag-/ I 430

Eyestone, R. ( I 977). Confusion, Diffusion, and Innovation. The American Political Science Review, 7 I (2), 44 I-447. doi: $10.2307 / 1978339$

Füglister, K. (20 I I a). Cantons as Policy Laboratories of the Federal State? The Diffusion of Health Insurance Subsidy Policies among the Swiss Cantons. (Doctoral Dissertation) University of Zürich.

Füglister, K. (20 I I b). Where does learning take place? The role of intergovernmental cooperation in policy diffusion. European Journal of Political Research, 5 I (3), 3 I 6-349. doi: I o. I I I I/j. I 475-6765.20 I I .02000.x

Gray, V. (1 973). Innovation in the states: A diffusion study. The American Political Science Review, 67(4), I I 74 - I I 85.

J\&G. (2007). All opportunities for all children, youth and family program 2007-20 I I [In Dutch: Alle kansen voor alle kinderen, programma voor Jeugd en Gezin 2007-20 I I ]. The Hague, The Netherlands: Programmaministerie voor Jeugd en Gezin.

Jacoby, W. G., \& Schneider, S. K. (200 I). Variability in state policy priorities: An empirical analysis. Journal of Politics, $63(2), 544-568$.

Karch, A. (2006). National intervention and the diffusion of policy innovations. American Politics Research, 34(4), 403426. doi: I 0. I I 77/ I 532673 Xo6288202

Karch, A. (2007a). Democratic Laboratories. Policy diffusion among the American states. Ann Arbor: The University of Michigan Press.

Karch, A. (2007b). Emerging issues and future directions in state policy diffusion research. State Politics E Policy Quarterly, 7(I), 54-80. doi:I 0.I I 77/153244000700700104

Konijnendijk, A. A. J., Boere-Boonekamp, M. M., Haasnoot-Smallegange, R. M. E., \& Need, A. (20 I 4). A qualitative exploration of factors that facilitate and impede adherence to child abuse prevention guidelines in Dutch preventive child health care. Journal of Evaluation in Clinical Practice, 20(4), 4 I 7-424. doi: I O. I I I I/jep. I 2 I 55

Maggetti, M., \& Gilardi, F. (20 I 4). Network governance and the domestic adoption of soft rules. Journal of European Public Policy, 2 I(9), I 293-I 3 I o. doi: I 0. I 08 o/ I 350 I 763.20 I 4.9230 I 8 


\section{CHAPTER SIX}

McCann, P. J. C., Shipan, C. R., \& Volden, C. (20 I 5). Top-Down Federalism: State Policy Responses to National Government Discussions. Publius: The Journal of Federalism, Advance online publication. doi: I $0.1093 /$ publius/pjvo 3

Mintrom, M., \& Norman, P. (2009). Policy entrepreneurship and policy change. Policy Studies Journal, 37(4), $649-667$.

Mohr, L. B. ( I 969). Determinants of innovation in organizations. The American Political Science Review, 63 ( I), I I II 26.

Moon, M. J. (2002). The evolution of e-government among municipalities: Rhetoric or reality? Public Administration Review, 62(4), 424-433.

Outshoorn, J. (2004). Voluntary and forced prostitution: the "realistic approach" of the Netherlands. In J. Outshoorn (Ed.), The politics of prostitution (pp. I 85-204). Cambridge University Press.

Pollitt, C. (2005). Decentralization. A central concept in contemporary public management. The Oxford Handbook of Public Management, 37 I-397.

Regeerakkoord VVD PvdA. Bruggen slaan (2012). Den Haag.

Rogers, E. M. (2003). Diffusion of innovations (5th ed.). New York: Free Press.

Sluiter, R. (20 I 2). The diffusion of morality policies among Western European countries between I 960 and 2010 : A Comparison of temporal and spatial diffusion patterns of six morality and eleven non-morality policies. (Doctoral Dissertation) Radboud University Nijmegen.

Sugiyama, N. B. (2008). Theories of policy diffusion: Social sector reform in Brazil. Comparative Political Studies, 4 I (2), I 93-2 I 6. doi: I 0. I I 77/00 I04 I 40073009 6

Tolbert, C. J., Mossberger, K., \& McNeal, R. S. (2008). Institutions, policy innovation, and e-government in the American states. Public Administration Review, 68(3), 549-563.

Van Eijck, S. (2006). Koersen op het kind. Sturingsadvies deel r. The Hague, The Netherlands: Projectbureau Operatie Jong.

Walker, J. L. (1969). Diffusion of innovations among American States. American Political Science Review, 63(3), 880899.

Walker, R. M. (2006). Innovation type and diffusion: An empirical analysis of local government. Public Administration, 84(2), 3 I I-335. doi: I O. I I I I/j. I 467-9299.2006.00004.X

Welch, S., \& Thompson, K. ( 1980 ). The impact of federal incentives on state policy innovation. American Journal of Political Science, 24(4), 7 I 5-729. Retrieved from http://www.jstor.org/stable/2 I I 0955 


\section{SUMMARY IN DUTCH (SAMENVATTING)}

Sinds de jaren '8o van de vorige eeuw zijn door een reeks van hervormingen en decentralisaties de verantwoordelijkheden voor Nederlandse gemeenten aanzienlijk toegenomen. Veel taken werden sindsdien overgedragen van de nationale overheid naar gemeenten. In 20 I 5 werd dit takenpakket nog verder uitgebreid door een drietal grote decentralisaties in het sociaal domein. Onder invloed van de economische crisis, de bezuinigingen en de door decentralisaties sterk veranderde bestuurlijke verhoudingen wordt veel gevraagd van het vermogen van gemeenten om in te spelen op nieuwe ontwikkelingen. Decentralisaties bieden gemeenten de mogelijkheid tot beleidsinnovatie; dat wil zeggen dat nieuw beleid wordt afgestemd op lokale prioriteiten en lokale omstandigheden. In dit proefschrift onderzoeken we hoe innovatief Nederlandse gemeenten zijn in het uitvoeren van door de nationale overheid gedecentraliseerde beleidstaken. De vraag die centraal staat gaat over het beschrijven en verklaren van verschillen tussen gemeenten in de mate van innovatie.

In de politiek, maar ook in normatieve theorieën over de voordelen en nadelen van decentralisaties, wordt vaak verondersteld dat lokale overheden bij uitstek geschikt zijn om beleid af te stemmen op de plaatselijke context. De vele mogelijkheden om te experimenteren met verschillende oplossingen voor beleidsproblemen wordt verondersteld te leiden tot een grote pluriformiteit aan lokaal passende en succesvolle beleidsinnovaties. In dit proefschrift leveren we een bijdrage aan de discussie over de houdbaarheid van de decentralisatie-these - die stelt dat bij de ontwikkeling van het lokale beleid, gemeenten gehoor geven aan lokale prioriteiten en lokale behoeften en eisen van hun burgers. De alternatieve hypothese die lijnrecht tegenover de decentralisatie-these staat is dat het niet de motivaties van gemeenten zijn die bepalen in hoeverre ze innovatief zijn in de uitvoering van gedecentraliseerd beleid, maar dat het de hoeveelheid lokale belemmeringen en lokale organisationele hulpbronnen zijn die bepalen in hoeverre er wordt geïnnoveerd. Het gaat dus primair om de vraag of de beleidsvernieuwingen samenhangen met verschillen in lokale prioriteiten en behoeften of dat ze worden bepaald door lokale obstakels en hulpbronnen.

Het vergelijken van de relatieve invloed van factoren die gaan over de motivaties van gemeenten enerzijds, met factoren die gaan over de obstakels en hulpbronnen van gemeenten anderzijds stelt ons in staat om de normatieve verwachtingen rondom decentralisaties te verbinden met de empirische vraag in hoeverre gemeenten daadwerkelijk nieuw beleid ontwikkelen dat is gebaseerd op lokale prioriteiten en lokale omstandigheden. In dit proefschrift beantwoorden we daarom de volgende onderzoeksvraag: 
In hoeverre zijn er verschillen tussen Nederlandse gemeenten in de uitvoering van gedecentraliseerd beleid en welke factoren kunnen deze verschillen tussen gemeenten verklaren?

We onderzoeken twee innovaties die door de nationale overheid aan gemeenten zijn opgelegd en die ze verplicht waren om in te voeren voor een bepaalde deadline. Daarnaast onderzoeken we twee innovaties waarin gemeenten een vrijwillige keuze hadden om wel of niet te innoveren. In het eerste geval beschouwen wij gemeenten die de innovatie eerder invoeren als meer innovatief en in het tweede geval beschouwen wij gemeenten die de innovatie omvangrijker invoeren als meer innovatief. Verschillen in de invoering van nieuw beleid tussen gemeenten worden in dit proefschrift dus bestudeerd aan de hand van verschillen in het moment waarop gemeenten innovaties doorvoeren (timing) en door het bestuderen van verschillen in de inhoud van de innovaties (content). Naast het onderscheid tussen opgelegde en vrijwillige innovaties maken we nog een onderscheid, namelijk dat tussen administratieve en politieke innovaties. De administratieve innovaties die we onderzoeken gaan over de hervorming van administratieve en bestuurlijke processen om bepaalde beleidsdoelen of bepaalde politieke doelen efficiënter of effectiever te bereiken. De politieke innovaties die we onderzoeken zijn ingevoerd en geïmplementeerd door gemeenten om bepaalde beleidsdoelen of politieke doelen gericht op het voorkomen of oplossen van maatschappelijke problemen te bereiken. Het onderscheid dat we maken in administratieve en politieke innovaties en opgelegde en vrijwillige innovaties leidt tot onderzoek naar vier verschillende typen innovaties.

Tabel 1. Vier studies naar gemeentelijke innovatie.

\begin{tabular}{lcc}
\hline & Administratief & Politiek \\
\hline \multirow{2}{*}{ Opgelegd } & E-government & Jeugd en Gezin \\
& (Hoofdstuk 2) & (Hoofdstuk 3) \\
\multirow{2}{*}{ Vrijwillig } & E-democracy & Prostitutie \\
& (Hoofdstuk 4) & (Hoofdstuk 5) \\
\hline
\end{tabular}

We onderzoeken in vier empirische hoofdstukken verschillende innovaties die administratief of politiek van aard zijn en die opgelegd dan wel vrijwillig van aard zijn. Tabel i laat de vierdeling zien die we in dit proefschrift gebruiken en laat per type beleid zien welke innovatie we onderzoeken. We onderzoeken of verschillen in het tijdstip van invoeren en verschillen in de inhoud van de innovatie vooral worden bepaald door lokale behoeften en prioriteiten of vooral door lokale obstakels en resources. De hoofdvraag die centraal staat in dit proefschrift is in vier innovatie-specifieke deelvragen uiteengelegd. De vier deelvragen worden in opeenvolgende hoofdstukken (Hoofdstukken 2-5) beantwoord. In Hoofdstuk 2 onderzoeken we een opgelegde administratieve innovatie en in Hoofdstuk 3 een opgelegde 
politieke innovatie. In Hoofdstuk 4 onderzoeken we een vrijwillige administratieve innovatie en in Hoofdstuk 5 een vrijwillige politieke innovatie.

Lokale politici en lokale beleidsmakers kunnen bij het maken van beleid intrinsiek of instrumenteel gemotiveerd zijn door de wens om beleid af te stemmen op lokale prioriteiten en omstandigheden. Ze kunnen wellicht worden weerhouden om beleid af te stemmen op lokale prioriteiten en lokale omstandigheden door de mogelijk aanwezige obstakels en een gebrek aan resources. Gemeenten kunnen dus wel willen innoveren, maar ze moeten het ook kunnen. Om te onderzoeken hoe dit in werkelijkheid zit toetsen we in alle vier de empirische hoofdstukken (Hoofdstukken 2-5) hypothesen over de invloed van interne en externe motivaties, obstakels en hulpbronnen van gemeenten. Onze verwachting voor de verschillende innovaties was dat de e-government innovatie (Hoofdstuk 2) en de Jeugd en Gezin innovatie (Hoofdstuk 3) meer afhankelijk zouden zijn van hulpbronnen en minder van motivaties, terwijl de e-democracy innovatie (Hoofdstuk 4) en de prostitutie innovatie (Hoofdstuk 5) minder afhankelijk zouden zijn van hulpbronnen en meer afhankelijk van motivatie-factoren. Wat de lokale obstakels voor innovatie betreft verwachten we dat deze voor alle vier de innovaties even belangrijk zijn. Tabel 2 laat de theoretische verwachtingen per type innovatie zien.

Tabel 2. Verwachting voor het belang van motivaties en resources per type beleid.

\begin{tabular}{ccc}
\hline & Administratief & Politiek \\
\hline Opgelegd & Hulpbronnen & Motivaties + Hulpbronnen \\
Vrijwillig & Motivaties + Hulpbronnen & Motivaties \\
\hline
\end{tabular}

In het laatste hoofdstuk (Hoofdstuk 6) kunnen we door middel van het vergelijken van de uitkomsten van de vier empirische hoofdstukken (Hoofdstukken 2-5) bepalen in welke mate bepaalde verklaringen meer verklaringskracht hebben afhankelijk van het type innovatie dat wordt onderzocht. In hoofdstuk 6 beantwoorden we ook de deelvragen die centraal stonden in de vier empirische hoofdstukken en de hoofvraag van dit proefschrift. We zullen nu de uitkomsten van de verschillende empirische hoofdstukken in deze dissertatie één voor één bespreken aan de hand van de afzonderlijke deelvragen. We sluiten de samenvatting af met het antwoord op de hoofdvraag en een korte conclusie voor het volledige proefschrift. 


\section{E-government: De invoering van de Basisregistratie Adressen en Ge- bouwen (BAG)}

In Hoofdstuk 2 onderzoeken we verschillen in het moment van invoeren van een opgelegde administratieve innovatie: de Basisregistratie Adressen en Gebouwen (BAG). De BAG is een nationaal-brede database die gegevens bevat over alle adressen en gebouwen van alle gemeenten in Nederland. De BAG had tot doel om alle adres en gebouw gegevens van gemeenten samen te brengen in één coherente database die gebruikt kan worden door zowel publieke als private organisaties. Deze innovatie werd door de nationale overheid aangekondigd in 2008 en diende door alle gemeenten te zijn gerealiseerd voor I juli 2009. Later werd deze deadline in samenspraak tussen de VNG en het Ministerie van VROM verschoven naar I januari 20 I I. De eerste deelvraag die we beantwoorden luidt als volgt: ( I) In hoeverre zijn er verschillen tussen Nederlandse gemeenten in het moment van invoeren van de $B A G$, en (2) hoe kunnen we deze verschillen verklaren?

Voor het beantwoorden van het eerste (beschrijvende) onderdeel van deelvraag één zijn we geïnteresseerd in verschillen tussen gemeenten in de timing van het realiseren van de BAG. We hebben data verzameld voor alle gemeenten om te achterhalen in welke maand ze gereed waren met de realisatie van de BAG. Op basis van de individuele invoeringsdata van alle gemeenten hebben we op verschillende tijdstippen gekeken naar de geografische spreiding van de BAG-realisaties. Daarnaast hebben we het cumulatieve aantal invoeringen van de BAG per maand in kaart gebracht om te kunnen bepalen of en hoe groot verschillen waren tussen gemeenten. Op basis van de beschrijvende gegevens in Hoofdstuk 2 (Figuren I -5 en Appendix I) concluderen we met betrekking tot deel één van deelvraag I dat verschillen tussen gemeenten in het moment van invoeren van de BAG aanzienlijk zijn en dat deze verschillen verdere verklaring nodig hebben.

Het tweede (verklarende) deel van deelvraag één beantwoorden we door hypothesen te toetsen over de motivaties, obstakels en hulpbronnen voor innovatie. Voor deze technische administratieve innovatie verwachten we dat vooral hulpbronnen verschillen in innovatie tussen gemeenten kunnen verklaren. Zoals verwacht waren motivaties inderdaad minder belangrijk dan hulpbronnen. Van de motivatie-factoren was er maar één factor (de ideologie van de gemeenteraad) die van invloed was op verschillen in innovatie. Gemeenten die wat betreft politiek-ideologische samenstelling meer gelijkenis vertonen met de regeringscoalitie van de nationale overheid zijn eerder met de invoering van de BAG. Verder vinden we dat obstakels niet van invloed zijn op verschillen in het moment van BAG-realisatie. Hulpbronnen zijn overduidelijk wel van invloed: gemeenten die beter geïnformeerd zijn, die in het verleden beter presteerden in andere e-government domeinen en gemeenten die in meer innovatieve beleidsnetwerken zitten hebben een grotere kans om deze innovatie eerder te realiseren. Zoals verwacht kunnen we voor deel twee van deelvraag één concluderen dat verschillen in innovatie vooral verklaard kunnen worden door hulpbronnen en slechts in beperkte mate door motivaties. Voor de decentralisatie-these betekenen deze bevindingen 
dat het niet lokale behoeften en prioriteiten, maar hulpbronnen zijn die verschillen in de snelheid van innovatie kunnen verklaren.

\section{Jeugd en Gezin: De realisatie van Centra voor Jeugd en Gezin (CJG)}

In hoofdstuk 3 van dit proefschrift onderzoeken we verschillen in het moment van invoeren van een opgelegde politieke innovatie: de invoering van Centra voor Jeugd en Gezin (CJG's). Gemeenten in Nederland zijn door de nationale overheid verplicht gesteld om een fysiek inlooppunt voor het lokale CJG te realiseren. Eind 2007 werd bekend gemaakt dat voor het einde van 20 I I iedere gemeente ten minste één duidelijk herkenbaar fysiek inlooppunt gerealiseerd moest hebben waarin organisaties die verantwoordelijk zijn voor jeugdzorg kunnen samenwerken in het aanbieden van hun diensten aan burgers. De belangrijkste doelen van de nationale overheid voor het nemen van deze maatregel waren om de kwaliteit van de jeugdzorg te verbeteren, de samenwerking tussen verschillende partners in het verstrekken van jeugdzorg te vergroten en om opvoedadvies en opvoedondersteuning te bieden voor alle gezinnen. Gemeenten kregen voor de realisatie van een CJG financiële hulpbronnen van de nationale overheid in de vorm van een Brede Doeluitkering Jeugd en Gezin. De tweede deelvraag die we beantwoorden luidt als volgt: ( I) In hoeverre zijn er verschillen tussen Nederlandse gemeenten in het moment van invoeren van een CJG, en (2) hoe kunnen we deze verschillen verklaren?

Voor het beantwoorden van het eerste (beschrijvende) deel van deelvraag twee hebben we gekeken welke verschillen er waren tussen gemeenten in de timing van de realisatie van een lokaal CJG. We hebben voor alle gemeenten geprobeerd te achterhalen in welke jaar ze gereed waren met de realisatie van een fysiek inlooppunt voor het lokale CJG. Om te kunnen bepalen of en hoe groot verschillen waren tussen gemeenten hebben we op basis van individuele invoeringsdata van gemeenten een overzicht gemaakt van het aantal invoeringen en het cumulatieve aantal invoeringen per jaar. Op basis van de beschrijvende gegevens in Hoofdstuk 3 (Tabel 2) aangevuld met beschrijvende gegevens in Hoofdstuk 6 (Figuur I) kunnen we concluderen met betrekking tot deel één van deelvraag 2 dat verschillen tussen gemeenten in het moment van realiseren van een lokaal CJG aanzienlijk zijn en dat deze verschillen nadere verklaring nodig hebben.

Voor het beantwoorden van het tweede (verklarende) deel van deelvraag twee toetsen we hypothesen over de effecten van gemeentelijke motivaties, obstakels en resources voor innovatie. De verwachting was dat motivaties belangrijker zijn dan hulpbronnen, omdat het een politieke innovatie betreft en omdat gemeenten financieel werden bijgestaan door de nationale overheid voor het uitvoeren van deze innovatie. We vonden een samenhang tussen de mate van politiek-ideologische gelijkenis van de gemeenteraad met de nationale overheid en eerdere realisatie van een CJG. Dit betekent dat wanneer gemeenten wat betreft politiek-ideologische samenstelling meer lijken op de regeringscoalitie van de nationale 
overheid ze eerder waren met de realisatie van een CJG. We vinden dat obstakels niet gerelateerd zijn aan verschillen tussen gemeenten in het moment van CJG-realisatie. Hulpbronnen zijn wel belangrijk voor het verklaren van verschillen tussen gemeenten. We vinden dat organisationele capaciteit belangrijk is en ook dat gemeenten in meer innovatieve beleidsnetwerken sneller zijn met de realisatie van een CJG. Het voorgaande is des te opmerkelijker gezien het feit dat gemeenten extra financiële middelen ontvingen in de vorm van de Brede Doeluitkering (BDU) Jeugd en Gezin. Ondanks deze extra middelen zijn het toch vooral hulpbronnen van gemeenten die belangrijk zijn voor deze innovatie en niet de gemeentelijke motivaties. Het antwoord op deelvraag twee impliceert voor de decentralisatie-these dat deze voor het grootste gedeelte niet opgaat. In plaats van lokale behoeften en prioriteiten, zijn de lokale hulpbronnen belangrijk voor het bepalen van de snelheid waarmee deze innovatie zich verspreidde onder gemeenten.

\section{E-democracy: De realisatie van e-democracy applicaties op gemeentelij- ke websites}

In hoofdstuk 4 van dit proefschrift onderzoeken we verschillen in de inhoud van een vrijwillige administratieve innovatie. We onderzoeken verschillen in hoe omvangrijk innovatie in e-democracy was doorgevoerd op gemeentelijke websites. Voor alle gemeenten in Nederland voor de jaren tussen 2007 en 20 I I brachten we de ontwikkeling in e-democracy in kaart. Nederlandse gemeenten zijn verantwoordelijk voor de kwaliteit van de lokale democratie, en één manier om de gemeentelijke democratische infrastructuur te verbeteren is door burgers te voorzien van online mogelijkheden om te participeren en om zichzelf te informeren over de lokale democratie. Gemeenten worden formeel gezien niet verantwoordelijk gehouden door de nationale overheid (of provincies) voor het verschaffen van lokale egovernment applicaties. Het is volledig aan de gemeenten zelf om te bepalen in welke mate ze elektronische democratische faciliteiten verschaffen. Deelvraag 3 die we beantwoorden luidt als volgt: ( I) In hoeverre zijn er verschillen tussen Nederlandse gemeenten in de mate van e-democracy ontwikkeling op gemeentelijke websites, en (2) hoe kunnen we deze verschillen verklaren?

Voor het beantwoorden van het eerste (beschrijvende) deel van deelvraag 3 hebben we voor alle gemeenten voor ieder jaar tussen 2007 en 20 I I een e-democracy score berekend. Gemeenten die hoog scoren hebben relatief veel digitale applicaties ontwikkeld die de transparantie van de overheid vergroten, die het publiek toegang verschaffen tot meer overheidsinformatie, en die zorgen voor sterkere burgerbetrokkenheid en meer burgerparticipatie. Op basis van de beschrijving van de e-democracy score in Hoofdstuk 4 (Tabel I) en Hoofdstuk 6 (Figuur 2) concluderen we met betrekking tot deel één van deelvraag drie dat verschillen tussen gemeenten in de mate van e-democracy realisatie aanzienlijk zijn en verdere verklaring nodig hebben. 
Het tweede (verklarende) deel van deelvraag drie beantwoorden we door hypothesen te toetsen over gemeentelijke motivaties, obstakels en resources voor innovatie. De verwachting was dat voor deze vrijwillige administratieve innovatie het een combinatie is van motivaties en hulpbronnen die verschillen in innovatie tussen gemeenten kan verklaren. We vinden dat gemeenten omvangrijkere e-democracy applicaties gerealiseerd hebben als ze zichzelf gesteld zagen voor een lagere verkiezingsopkomst tijdens gemeenteraadsverkiezingen, wanneer er meer potentiele e-government gebruikers zijn, wanneer partijen en politici die politiek-ideologisch veel waarde hechten aan e-government een sterkere positie innemen, en wanneer gemeenten relatief veel lokale politici met een persoonlijke voorkeur voor e-democracy hebben. Wat betreft de obstakels voor innovatie vinden we - anders dan verwacht - dat wanneer een gemeente een sterker gefragmenteerde gemeenteraad had er meer werd geïnnoveerd in e-democracy. Hulpbronnen die ertoe doen voor de mate van edemocracy innovatie zijn; een grotere organisationele capaciteit, betere prestaties in het verleden in andere e-government domeinen en wanneer een gemeente een burgemeester of wethouder had die specifiek belast was met de beleidsportefeuille ICT. Het antwoord op het tweede deel van deelvraag drie is dat motivaties en hulpbronnen ongeveer even belangrijk zijn voor het verklaren van verschillen tussen gemeenten in de mate van innovatie. Ook obstakels doen ertoe, maar in tegenstelling tot wat we verwacht hadden voor deze vrijwillige administratieve innovatie hebben ze een positief effect op innovatie. Met betrekking tot de decentralisatie-these - die stelt dat na de decentralisatie gemeenten hun beleid bepalen aan de hand van lokale behoeften en prioriteiten - impliceert het antwoord op deelvraag drie dat de these slechts gedeeltelijk opgaat. Motivatie-factoren zoals lokale behoeften, lokale vraag en lokale ideologische prioriteiten doen er weliswaar toe, maar ook hulpbronnen (en obstakels) zijn relevant voor innovatie.

\section{Prostitutie: De inhoudelijke ontwikkeling van lokaal prostitutiebeleid na de opheffing van het bordeelverbod}

In hoofdstuk 5 van deze dissertatie onderzoeken we verschillen tussen gemeenten in innovatie in de inhoud van een vrijwillige politieke innovatie. We onderzochten voor een steekproef van Nederlandse gemeenten verschillen in de inhoud van lokaal beleid dat werd ontwikkeld naar aanleiding van het opheffen van het bordeelverbod in het jaar 2000. Door het opheffen van het bordeelverbod in oktober 2000 werd prostitutie in Nederland bij wet legaal. Deze hervorming was bedoeld om misstanden in de seksbranche te beëindigen. Gemeenten werden weliswaar verantwoordelijk voor het voeren van lokaal prostitutiebeleid, maar ze werden niet gedwongen door de nationale overheid om prostitutieregelgeving op te nemen in lokaal beleid. Om gemeenten die lokale regelgeving omtrent prostitutie wilden invoeren te helpen ontwierp de VNG een zogenoemde modelverordening die gemeenten als voorbeeld voor eigen beleid konden gebruiken. We onderzoeken de mate waarin gemeenten 
deze modelverordening overnamen en de mate waarin ze deze hebben aangepast aan lokale behoeften en prioriteiten. De deelvraag die we in hoofdstuk 5 beantwoorden luidt als volgt: ( I) In hoeverre zijn er verschillen tussen Nederlandse gemeenten in de hoeveelheid aanpassingen in de inhoud van de modelverordening prostitutie, en (2) hoe kunnen we deze verschillen verklaren?

Het eerste (beschrijvende) deel van deelvraag vier hebben we kunnen beantwoorden door voor alle gemeenten de lokale prostitutieregelingen te vergelijken met de modelverordening van de VNG. We vinden dat lokale prostitutieregelingen over het algemeen erg veel overeenkomst vertonen met de modelverordening, maar tegelijkertijd vinden we dat er tussen gemeenten onderling behoorlijke verschillen zijn in de mate van overlap met de modelverordening. Op basis van de beschrijving van de overlap-scores in Hoofdstuk 5 (Figuur I-3) concluderen we met betrekking tot deel één van deelvraag vier dat er aanzienlijke verschillen zijn tussen gemeenten in het aantal inhoudelijke veranderingen aan de modelverordening.

Het tweede (verklarende) deel van deelvraag vier beantwoorden we door hypothesen te toetsen over de motivaties, obstakels en hulpbronnen voor innovatie. Voor deze vrijwillige politieke innovatie was de verwachting dat vooral motivaties verschillen in de mate van innovatie kunnen verklaren. We vinden dat de mate waarin het lokale beleid inhoudelijk werd aangepast niet wordt beïnvloed door lokale behoeften en politieke prioriteiten. Obstakels vormden in dit geval een belemmering voor het maken van meer aanpassingen aan de modelverordening, want politiek sterker gefragmenteerde gemeenten kopieerden de modelverordening in grotere mate. In plaats van lokale prioriteiten en behoeften waren het aan organisationele capaciteit gerelateerd hulpbronnen die ervoor zorgen dat gemeenten de modelverordening in grotere mate veranderden. Het antwoord op deel twee van deelvraag vier is dat het niet motivaties maar vooral obstakels en hulpbronnen zijn die de mate van innovatie bepalen. Met betrekking tot de decentralisatie-these betekent dit antwoord dat de manier waarop het nieuwe beleid werd ingevoerd niet zozeer werd bepaald door lokale behoeften en prioriteiten, maar door lokale hulpbronnen (en obstakels).

\section{Conclusie}

$\mathrm{Nu}$ we de antwoorden op de verschillende deelvragen hebben besproken kunnen we op basis daarvan ook een antwoord geven op de hoofdvraag van dit proefschrift: In hoeverre zijn er verschillen tussen Nederlandse gemeenten in de uitvoering van gedecentraliseerd beleid en welke factoren kunnen deze verschillen tussen gemeenten verklaren? Om deze vraag te beantwoorden hebben we in vier empirische hoofdstukken vier verschillende innovaties onderzocht. We hebben voor iedere combinatie tussen vrijwillige of opgelegde innovaties en tussen administratieve of politieke innovaties één specifieke innovatie onderzocht. Het antwoord op het beschrijvende deel van de hoofdvraag is gebaseerd op de vier 
antwoorden op de beschrijvende onderdelen van de vier deelvragen. Het antwoord is dat voor alle vier de innovaties verschillen tussen gemeenten in de mate van innovatie aanzienlijk zijn. Dit geldt zowel voor de opgelegde innovaties in de mate van verschillen in timing als voor de vrijwillige innovaties in de mate van verschillen in content.

Wat betreft het verklarende deel van de hoofdvraag hebben we laten zien dat de snelheid waarmee innovaties worden ingevoerd en de mate van innovatie in de inhoud van beleid beide vooral worden bepaald door de aanwezigheid van voldoende hulpbronnen (Hoofdstuk I-2 en 4). Incidenteel worden verschillen in innovatie ook verklaard door motivaties, zoals lokale behoeften, eisen van burgers en politieke ideologische overwegingen (Hoofdstuk 3). Obstakels zijn slechts in beperkte mate verantwoordelijk voor verschillen in innovatie (Hoofdstuk 4-5). Naast de invloed van lokale motivaties, obstakels en hulpbronnen zijn er ook externe factoren die belangrijk zijn. Horizontaal is er de invloed van andere gemeenten in hetzelfde regionale beleidsnetwerk dat belangrijk is voor het individuele innovatiegedrag van gemeenten (Hoofdstuk 2-3). Professionele (politieke) netwerken hebben geen invloed op innovatie (Hoofdstukken 3-5). Verticaal is er de invloed van een nationale organisatie, de Vereniging voor Nederlandse Gemeenten (VNG) (Hoofdstuk 5) en de invloed van de nationale overheid (Hoofdstuk 2-3) op gemeentelijke innovatie.

Tabel 3 laat voor alle vier de innovaties zien wat onze verwachtingen en bevindingen zijn voor de invloed van motivaties en hulpbronnen. Te zien is dat onze verwachtingen voor de administratieve innovaties worden bevestigd en dat onze verwachtingen voor de politieke innovaties voor het grootste deel worden verworpen. Het antwoord op het verklarende deel van hoofdvraag is dan ook dat de invloed van obstakels verwaarloosbaar is, dat er slechts marginaal invloed is van motivaties, en dat vooral hulpbronnen belangrijk zijn voor het verklaren van verschillen tussen gemeenten in de mate van innovatie.

Tabel 3. Het belang van motivaties en hulpbronnen per type innovatie: verwachtingen en bevindingen.

\begin{tabular}{lcccc}
\hline & \multicolumn{2}{c}{ Administratief } & \multicolumn{2}{c}{ Politiek } \\
\cline { 2 - 5 } Opgelegd & Verwachting & Bevinding & Verwachting & Bevinding \\
\cline { 2 - 5 } Vrijwillig & Hulpbronnen & Hulpbronnen & $\begin{array}{c}\text { Motivaties }+ \\
\text { Hulpbronnen }\end{array}$ & Hulpbronnen \\
& $\begin{array}{c}\text { Motivaties }+ \\
\text { Hulpbronnen }\end{array}$ & $\begin{array}{c}\text { Motivaties + } \\
\text { Hulpbronnen }\end{array}$ & Motivaties & Hulpbronnen \\
\hline
\end{tabular}

Onze bevindingen laten zien dat gemeentelijke innovatie in een gedecentraliseerde context vooral wordt bepaald door de aanwezigheid van voldoende hulpbronnen om te kunnen innoveren en niet zozeer door lokale behoeften en prioriteiten zoals vaak wordt verondersteld. Onze bevindingen vormen een nuancering van de decentralisatie-these, omdat gemeenten maar in zeer beperkte mate in staat zijn gebleken om beleid te ontwikkelen op 
basis van specifieke lokale behoeften en lokale prioriteiten. We concluderen dat het effect van obstakels valt te verwaarlozen, dat motivaties er slechts in beperkte mate toe doen en dat het vooral hulpbronnen zijn die verschillen in innovatie tussen Nederlandse gemeenten kunnen verklaren.

De decentralisaties in het sociaal domein die vanaf begin 20 I 5 in Nederland zijn ingevoerd werden vergezeld met de opdracht aan gemeenten om "meer te doen met minder financiële middelen". We hebben laten zien dat innovatief handelen door gemeenten zeker mogelijk is wanneer gemeenten over voldoende hulpbronnen beschikken en in mindere mate voor gemeenten zonder de beschikking over voldoende hulpbronnen. Op basis van onze bevindingen in dit proefschrift kunnen we dan ook stellen dat de decentralisatie van beleid en een gelijktijdige verlaging van financiële middelen een niet erg veelbelovende combinatie is. 


\section{ACKNOWLEDGMENTS}

It is impossible to conduct scientific research without collaboration and support. A professional, friendly, helpful, and diverse network of people made it possible to complete my dissertation with pleasure and satisfaction.

I was very lucky to write my dissertation under the supervision of three highly skilled and passionate supervisors. Ariana Need, Bas Denters, and Minna van Gerven have all three contributed to the completion of this dissertation in their very own way. Ariana, your enthusiasm for science in general, and your quality for asking the right empirical questions have really helped me to develop research of my own. You taught me to stay focused on what the particular paper was about and to drop side paths that did not contribute to answering a specific research question. Also your attention to detail helped to improve this dissertation. Bas, your affinity with, and scientific knowledge about, local government helped me to become quickly familiar in an at the time new world to me. You learned me to take drastic measures to restructure pieces of work whenever necessary. Several chapters in this dissertation benefited strongly from your suggestions for restructuing the major lines. Minna, your passion for science and scientific education has provided me with insights into academia as such. From you I learned - when drowning in details - to continue to focus on the bigger picture. This dissertation is much dependent on our meetings to discuss renewed structures of papers, updated time-schedules, and premature ideas for new chapters. I am pleased that we continue to work together for my post-doc project.

I would also like to express my appreciation to the members of my doctoral committee: Jan van Dijk, Albert Meijer, Karen Mossberger, Sandra van Thiel and René Torenvlied. A special thanks to Karen Mossberger - for her co-authorship on Chapter 4 - and her husband Gregg Mossberger for their great hospitality during my stay at the School of Public Affairs at Arizona State University in Phoenix.

Many current and former colleagues provided an intellectually stimulating and supportive environment for writing my dissertation. These people include all colleagues from the Public Administration department, and some people in particular. Thanks for the many serious and the sometimes 'somewhat' less serious conversations and discussions (about almost anything) during lunchtime or at the coffee machine: Henk van der Kolk, Pieter-Jan Klok, Giedo Jansen, Veronica Junjan, Jörgen Svensson, Martin Rosema, Maurits Sanders, Adrie Dassen, Carolien van Ham, Kostas Gemenis, Ann Morissens, Kees Aarts, and Harry van der Kaap. For their massive practical support I would like to thank Annette van der Tuuk and Manon Jannink-van het Reve. I would also like to thank my fellow-PhD's for being supportive and for showing interest in my work: Kira Killerman, Claudio Matera, 
Sedef Turper, Ann-Kristin Kölln, Wenqi Dang, Joost van den Akker, Qing Qian Hé, Silvia Rossetti, Yasmin Lurusati, Amaury Lefèvre, and Anna Priante. I am especially grateful to my roommates for sharing in the bonding experience of writing a dissertation: Cherelle van Stenus, Ben Boksebeld, Mariecke van den Berg, and Judith Bakker. A very warm and special thanks to my two paranymphs Annemieke Konijnendijk and Rense Nieuwenhuis with whom I shared everything spanning academia, model estimation strategies, syntaxes, (good and bad) coffee, visions on science, and daily life. Your collegiality definitely benefited my dissertation process.

For the data used in all chapters I was dependent on the help of many people. First, I would like to thank all Dutch municipalities that have sent me their local by-law on prostitution (Chapter 5). Also, thanks to all local VNG-departments for providing me information for the construction of the professional network variable (Chapters 3-5). There are also some people I would like to thank individually: Lodewijk Jessen (VROM), Norbert Schmelzer (VROM), and Lars Rengersen (Monito B.V.) (Chapter 2). Julia Houwer, Myrte de Jong, and Annelieke van den Heuvel (BMC Consultancy and Management) (Chapters 3 and 4 ). Ron de Jong (Kiesraad), Peter Castenmiller (PBLQ Zenc), and Freek Ogink (nlverkiezingen.nl) for providing political and election data (Chapter 2-4). Ageeth de Jager (Daadkracht B.V.), Niko Winkel (ICTU), Bart-Jan Flos (Daadkracht B.V.), and Frank Sibbel (Blauw Research B.V.) (Chapters 2 and 4 ). Jan Visser (Mr. A de Graaf Stichting) (Chapter 5). Special thanks to Wouter Witteveen who interned at our department and helped me with the coding of documents (Chapter 5 ).

My good-humored friends who knew me long before I started writing my dissertation are always great company. Your e-mails, phone calls, text-messages, visits, NS-railway-walks, and prompt suggestions for how to be thanked in these acknowledgments, brought me the distractions and energy necessary for a good work-life balance. Thanks for being such good friends: Krein Jongmans, Gerben Kuijpers, Geert Nellen, Mark van Ostaijen, Paul Roks, and Tim Simonse.

Finally, a few words for my family. Thanks mom and dad, Corien and Rob, for your help and stimulation to further study Sociology, and for your never-ceasing interest in all my activities. I am happy to know that you found a beautiful home (with a nice guest room) to enjoy life and work. My two sisters, Simone and Carlijn, thanks for your interests in all my whereabouts and doings. It is good to see that you are happy with your family, work and sporting career. I am proud of you. I would also like to thank all four my grandparents, but in particular 'grandma De Lint', for being always supportive and for your capability to appreciate the skills and good in every person. Your resilience is inspiring. Thanks also to my parents-in-law, Conny and Thijs Trompetter, for taking me into your family, for your interest and advice. I would also like to thank my 'newest' and extended family members: Joris, Bente, and Jurre Blankensteijn, Bas, Daan, and Floor Ghijssen, Robbert, Marion, Senna and Tiemen Trompetter, and Jacco, Vonneke, Ilse, and Matthijs Neleman. Thanks 
for all the pleasure you bring to all of us and the time we spend together. Most importantly, a final thanks is for my girlfriend Hester Trompetter. Hester, with you by my side the process of writing a dissertation was far easier and more fun. Your love, support, humor, and your belief in me, make me a much happier person.

Wouter Jans

Carrboro, North Carolina, November 20 I 5 


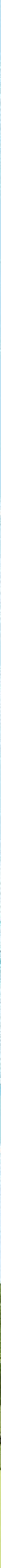